Prepared in cooperation with the Wayne Conservation District

\title{
Baseline Assessment of Groundwater Quality in Wayne County, Pennsylvania, 2014
}

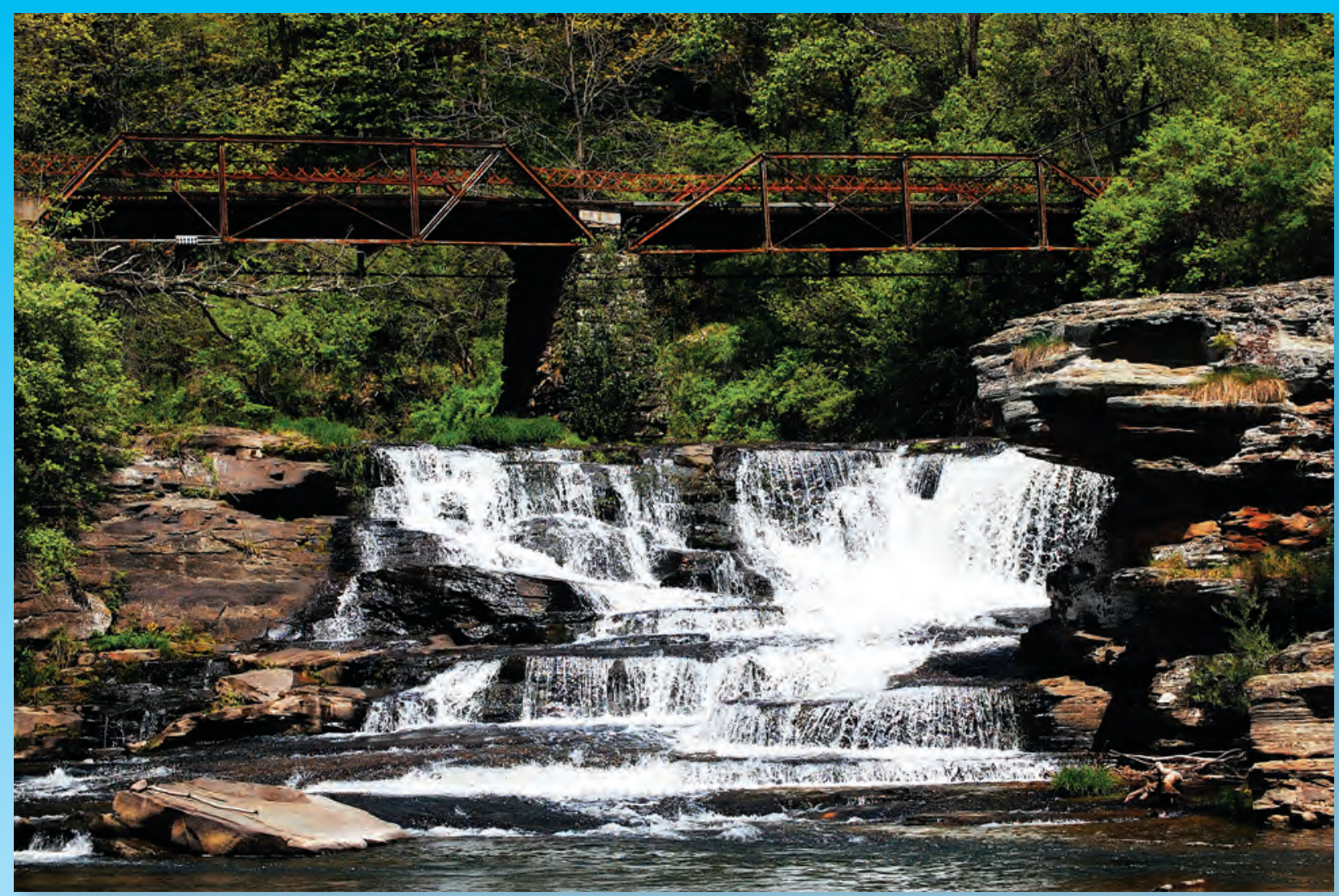

Scientific Investigations Report 2016-5073

Version 1.1, March 2017

U.S. Department of the Interior

U.S. Geological Survey 
Cover. Tanners Falls and exposure of Devonian-age sedimentary rocks of the Catskill Formation, Dyberry Township, Wayne County, Pennsylvania, May 2016. (Photograph by Sylvia Thompson, Wayne Conservation District.) 


\section{Baseline Assessment of Groundwater Quality in Wayne County, Pennsylvania, 2014}

By Lisa A. Senior, Charles A. Cravotta, III, and Ronald A. Sloto

Prepared in cooperation with the Wayne Conservation District

Scientific Investigations Report 2016-5073

Version 1.1, March 2017 


\title{
U.S. Department of the Interior SALLY JEWELL, Secretary
}

\section{U.S. Geological Survey Suzette M. Kimball, Director}

\author{
U.S. Geological Survey, Reston, Virginia \\ First Release: 2016, online \\ Revised: March 2017 (ver. 1.1), online
}

\begin{abstract}
For more information on the USGS - the Federal source for science about the Earth, its natural and living resources, natural hazards, and the environment, visit http://www.usgs.gov or call 1-888-ASK-USGS

For an overview of USGS information products, including maps, imagery, and publications, visit http://store.usgs.gov

To order this and other USGS information products, visit http://store.usgs.gov
\end{abstract}

Any use of trade, product, or firm names is for descriptive purposes only and does not imply endorsement by the U.S. Government.

Although this report is in the public domain, permission must be secured from the individual copyright owners to reproduce any copyrighted materials contained within this report.

Suggested citation:

Senior, L.A., Cravotta, C.A., III, and Sloto, R.A., 2017, Baseline assessment of groundwater quality in Wayne County, Pennsylvania, 2014 (ver. 1.1, March 2017): U.S. Geological Survey Scientific Investigations Report 2016-5073, 136 p., http://dx.doi.org/10.3133/sir20165073.

ISSN 2328-0328 (online) 


\section{Acknowledgments}

The participation of individual well owners who made their wells accessible for the study is appreciated. The assistance and cooperation of Jamie Knecht of the Wayne Conservation District in obtaining grant funding from the Pennsylvania Department of Community and Economic Development Baseline Water Quality Program, identifying and obtaining permission from well owners, and conducting field work is gratefully acknowledged. U.S. Geological Survey (USGS) personnel from the New York Water Science Center and Pennsylvania Water Science Center who collected the groundwater samples include Tia-Marie Scott, Paul Heisig, Richard Reynolds, and Dana Heston. Linda Zarr of USGS assisted in data processing. 



\section{Contents}

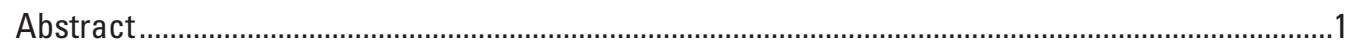

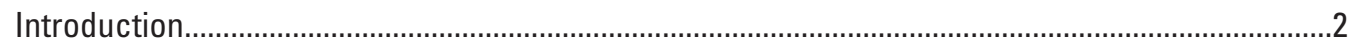

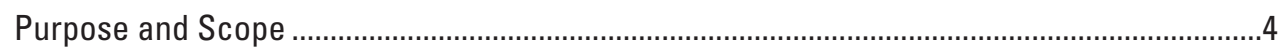

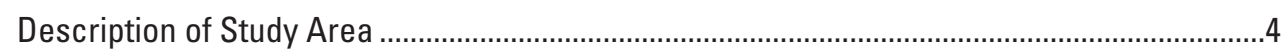

Physiography and Geologic Setting ..........................................................................

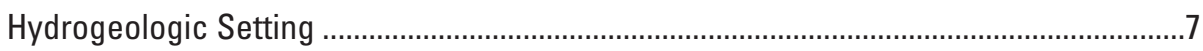

Previous Investigations........................................................................................................

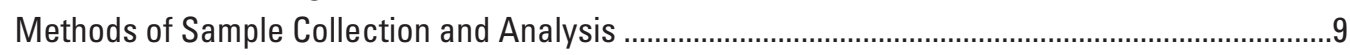

Selection of Sampling Locations........................................................................................... 10

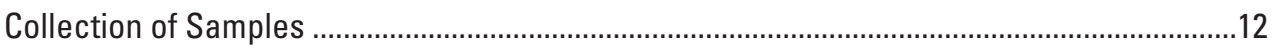

Analysis of Chemical, Physical, and Other Characteristics and Reporting Units...................12

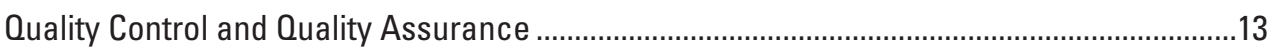

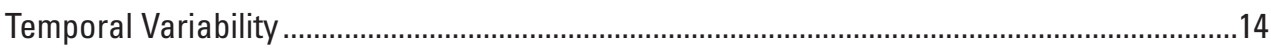

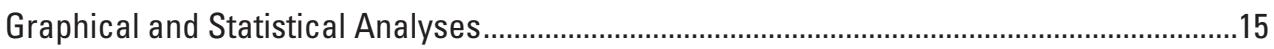

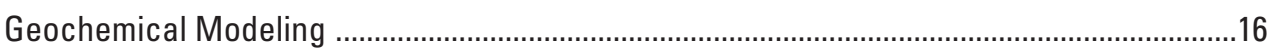

Baseline Groundwater Quality in Wayne County ..................................................................16

Geochemical Controls on Selected Constituents in Groundwater.......................................17

Wayne County Groundwater Quality and Its Relation to Drinking-Water Standards .............17

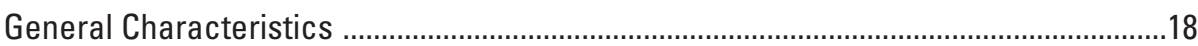

Field measurements of pH, Alkalinity, Specific Conductance, and

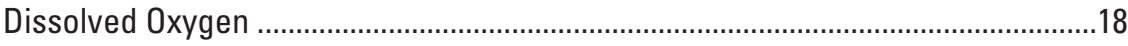

Total Dissolved Solids, Total Solids, Hardness, and Corrosivity ..............................18

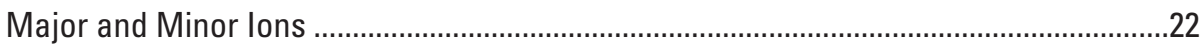

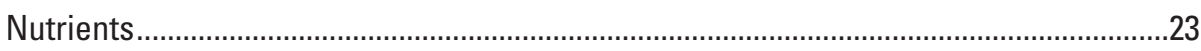

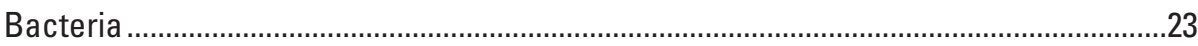

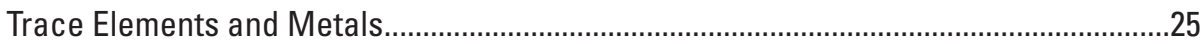

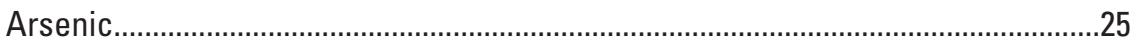

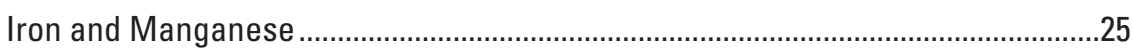

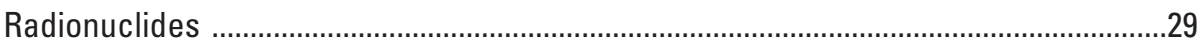

Gross alpha- and gross beta-particle radioactivity ............................................29

Radon-222

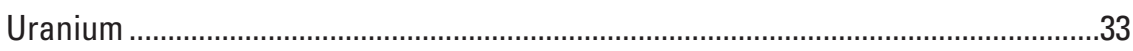

Man-made Organic Compounds .................................................................................33

Methane and Other Dissolved Hydrocarbon Gases .....................................................33

Methane Isotopic Composition and Origin of Methane Gas ....................................35

Geochemical Modeling and Analysis of Water Quality Data .........................................................4

Types of Groundwater as Characterized by Major lons.....................................................4

Ratios of Chloride, Bromide, and Sodium in Groundwater .................................................48

Correlations Among Major and Trace Constituents in Groundwater.....................................52

Evolution of Chemical Composition and Conceptual Hydrogeochemical Model.....................55 
Geochemical Modeling .55

Conceptual Hydrogeochemical Model ......................................................................61

Spatial Distribution of Groundwater Quality and Relation to Hydrogeologic Setting ............63

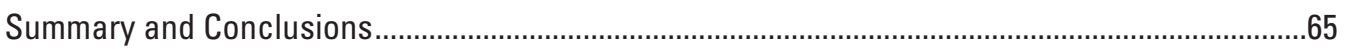

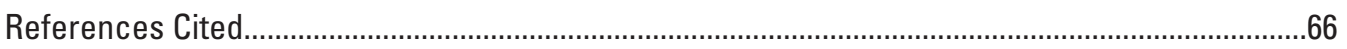

Appendix 1. Summary of water-quality data for 34 groundwater samples collected in Wayne County, Pennsylvania, during 2011 and 2013...................................................100

Appendix 2. Analytical methods and reporting levels for constituents analyzed,

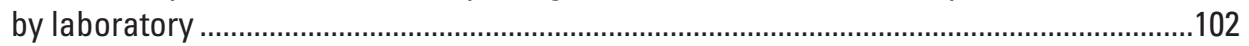

Appendix 3. Quality assurance and quality control data .............................................................105

Appendix 4. Spearman rank correlation coefficients and boxplots showing sample compositions by groups $(\mathrm{pH}$ and redox ranges, principal components) for groundwater samples collected from Wayne County, Pennsylvania, 2013-14

\section{Figures}

1. Map showing location of Wayne County, Pennsylvania, and gas wells drilled from 2005 through August 2015.

2. Map showing physiography, geology of the bedrock closest to land surface, and location of sampled wells in 2013 and 2014 in Wayne County, Pennsylvania.............5

3. Stratigraphic correlation chart for Devonian-age and younger geologic units, Wayne County, Pennsylvania.

4. Graph showing observed daily mean water levels during 2013-14 and long-term (1987-2014) daily median water levels in an observation well WN-64, Wayne County, Pennsylvania

5. Map and graphs showing $A$, land-surface elevation, streams, and location of wells sampled for baseline groundwater quality assessments in Wayne County, Pennsylvania during 2013 and 2014, B, transect A-A' showing land-surface elevation, and $C$, transect $B-B^{\prime}$ showing land-surface elevation.

6. Map showing spatial distribution of $\mathrm{pH}$ in water samples collected from 89 wells in 2014 and 32 wells in 2013 in Wayne County, Pennsylvania

7. Graphs showing relation between field measured $\mathrm{pH}$ and $A$, laboratory alkalinity, $B$, field specific conductance, and $C$, dissolved oxygen concentrations in water samples collected from 89 wells in Wayne County, Pennsylvania, July-September 2014

8. Graph showing relation between field measured specific conductance and concentrations of total dissolved solids in water samples collected from 89 wells in Wayne County, Pennsylvania, July-September 2014

9. Graphs showing relation between field measured $\mathrm{pH}$ and $A$, hardness, and $B$, corrosivity (as measured by calcite saturation index) in water samples collected from 89 wells in Wayne County, Pennsylvania, July-September 2014 
10. Map showing spatial distribution of dissolved sodium concentrations in water samples collected from 89 wells in 2014 and 32 wells in 2013 in Wayne County, Pennsylvania ..

11. Graphs showing relation between field measured $\mathrm{pH}$ and dissolved concentrations of $A$, arsenic, $B$, molybdenum, antimony, and selenium, and $C$, copper and lead in water samples collected from 89 wells in Wayne County, Pennsylvania, July-September 2014.

12. Map showing spatial distribution of dissolved arsenic concentrations in water samples collected from 89 wells in 2014 and 32 wells in 2013 in Wayne County, Pennsylvania

13. Graphs showing concentrations of dissolved iron and manganese in relation to concentrations of $A$, dissolved oxygen, $B$, nitrate, and $C$, sulfate in water samples collected from 89 wells in Wayne County, Pennsylvania, July-September 2014.

14. Graphs showing concentrations of total and particulate iron and manganese in relation to concentrations of $A$, dissolved oxygen and $B$, $\mathrm{pH}$, in water samples collected from 89 wells in Wayne County, Pennsylvania, July-September 2014.

15. Graphs showing relation between $A$, gross alpha-particle activity and gross beta-particle activity, $B$, gross alpha-particle activity and dissolved uranium concentrations, and $C$, gross beta-particle activity and dissolved uranium concentrations in water samples collected from 89 wells in Wayne County, Pennsylvania, July-September 2014

16. Map showing spatial distribution of radon-222 activities (concentrations) in water samples collected from 89 wells in 2014 and 32 wells in 2013 in Wayne County, Pennsylvania

17. Graph showing dissolved uranium concentrations in relation to field measured $\mathrm{pH}$ in water samples collected from 89 wells in Wayne County, Pennsylvania, July-September 2014

18. Map showing spatial distribution of dissolved uranium concentrations in water samples collected from 89 wells in 2014 and 32 wells in 2013 in Wayne County, Pennsylvania

19. Map showing spatial distribution of dissolved lithium and relatively elevated (>0.7 mg/L) methane concentrations in water samples collected from 89 wells in 2014 and 32 wells in 2013 in Wayne County, Pennsylvania

20. Graph showing isotopic composition of methane in water samples collected from eight wells in 2014, Wayne County, Pennsylvania

21. Graphs showing $A$, Isotopic composition of methane in water samples collected from eight wells in Wayne County, Pennsylvania, 2014, and in mud-logging gas samples collected from different geologic formations during drilling of Marcellus Shale gas wells in Pennsylvania, and $B, C 1 / C 2$ (methane/ethane) ratios in relation to carbon-isotopic composition for methane in these same samples.

22. Graphs showing relation of field measured $\mathrm{pH}$ to dissolved $A$, arsenic, bromide, fluoride, and methane concentrations, $B$, sodium, lithium, and boron concentrations, and $C$, barium and strontium concentrations in water samples collected from 89 wells in Wayne County, Pennsylvania, July-September 2014 
23. Trilinear (Piper) diagrams showing major ion composition for $A$, predominant water types or hydrochemical facies, $B$, water samples collected from 117 wells in Wayne County, Pennsylvania, 2013-14 plus median composition of brine from oil and gas wells in western Pennsylvania and flowback water from Marcellus Shale gas wells, C, 11 selected groundwater samples from Wayne County, 2013-14, and $D$, evolution pathways for mixing of dilute $\mathrm{Ca}-\mathrm{HCO}_{3}$ groundwater with road salt; with brine; with brine combined with cation exchange; or with brine plus calcite dissolution to saturation and then cation exchange

24. Pie charts showing typical ionic contributions to computed specific conductance (SC) for selected groundwater samples from Wayne County, 2014, for wells $A$, WN-345, $B, \mathrm{WN}-371, C, \mathrm{WN}-361$, and $D, \mathrm{WN}-295$

25. Graphs showing chloride concentrations in relation to $A$, chloride/bromide mass ratios for various ranges of bromide concentrations, $B$, chloride/bromide mass ratios for samples with and without elevated ( $>1.0 \mathrm{mg} / \mathrm{L}$ ) methane concentrations, $C$, bromide concentrations, and $D$, sodium concentrations for 121 groundwater samples collected from 117 wells in Wayne County, Pennsylvania, 2013-14, plus median values for Salt Spring, flowback waters from Marcellus Shale gas wells, and oil- and gas-field brines from Western Pennsylvania

26. Graphs showing saturation indices for minerals and other solids in relation to $\mathrm{pH}$ for 121 groundwater samples from 117 wells in Wayne County, Pennsylvania, 2013-14.

27. Graphs showing equilibrium fractions of initial concentrations of $A$, anions or $B$, cations that may be dissolved or adsorbed on a finite amount of hydrous ferric oxide (HFO) at 25 degrees Celsius as a function of $\mathrm{pH}$ .58

28. Graphs showing computed compositions of waters resulting from initial composition of low-ionic strength groundwater (from well WN-371) with dissolution of road deicing salt $\left(\mathrm{NaCl}_{0.99996} \mathrm{Br}_{0.00004}\right)$ and (or) calcite, but without cation exchange. Low ionic strength groundwater (WN-371) with $A$, dissolution of deicing salt but without other reactions, $B$, mixing with median oil and gas well brine but without other other reactions, $C$, dissolution of deicing salt plus calcite $\left(\mathrm{CaCO}_{3}\right)$ dissolution to equilibrium (saturation index $=0$ ), and $D$, mixing with median oil and gas well brine plus calcite dissolution to equilibrium

29. Graphs showing computed composition of waters resulting from initial composition of low-ionic strength groundwater (from well WN-371) with reactions including dissolution of calcite and (or) cation exchange and (or) mixing with different amounts of brine. Low-ionic strength groundwater (WN-371) with dissolution of incremental amounts of calcite $\left(\mathrm{CaCO}_{3}\right)$ until reaching equilibrium $A$, without cation exchange, $B$, with cation exchange. Low-ionic strength groundwater (WN-371) mixes with median oil and gas well brine $C$, with cation exchange, and $D$, with calcite dissolution to equilibrium and cation exchange.

30. Schematic diagram of generalized conceptual hydrogeochemical model for distribution of fresh and saline groundwater in fractured bedrock aquifer setting

31. Boxplots showing distribution of well bottom elevations, land surface elevations, and well depths for groundwater samples from 117 wells in Wayne County, Pennsylvania, 2013-14, grouped by $\mathrm{pH}$ class interval as "acidic" (5.4< pH <6.4, n=29), "neutral" $(6.5<\mathrm{pH}<7.4, \mathrm{n}=32)$, "alkaline" $(7.5<\mathrm{pH}<7.9, \mathrm{n}=25)$, and "very alkaline" $(8.0<\mathrm{pH}<9.4, \mathrm{n}=9)$ 
3-1. Graphs showing total dissolved solids and specific conductance for 121 groundwater samples collected from 117 wells in Wayne County, Pennsylvania, 2013-14. A, Relation of measured total dissolved solids [as residue on evaporation (ROE) at 180 degrees Celsius] to calculated total dissolved solids, $B$, relation of field measued specific conductance to laboratory measured specific conductance, $C$, relation of field measured specific conductance to calculated concentration of total dissolved solids, and $D$, relation of field measured specific conductance to specific conductance calculated on the basis of ionic conductivities .

3-2. Graphs showing $A$, Relation of laboratory measured specific conductance to estimated ionic conductivity, and $B$, cumulative percentage of ionic contributions to specific conductance/conductivity for 121 groundwater samples collected from 117 wells in Wayne County, Pennsylvania, 2013 and 2014, in order of increasing specific conductance. Four of 117 wells are identified by U.S. Geological Survey local well numbers in $B$.

4-1. Boxplots showing differences in compositions of 121 groundwater samples from 117 wells in Wayne County, Pennsylvania, 2013-14, classified by $\mathrm{pH}$ class interval as "acidic" $(5.4<\mathrm{pH}<6.4, \mathrm{n}=29)$, "neutral" $(6.5<\mathrm{pH}<7.4$, $\mathrm{n}=32)$, "alkaline" (7.5<pH $<7.9, \mathrm{n}=25)$, and "very alkaline" $(8.0<\mathrm{pH}<9.4, \mathrm{n}=9)$.

4-2. Boxplots showing differences in compositions of 121 groundwater samples from 117 wells in Wayne County, Pennsylvania, 2013-14, classified as "anoxic" ( $n=25)$, "mixed" ( $n=1)$, and "oxic" ( $n=95)$ on the basis of dissolved oxygen concentration and other water-quality criteria of McMahon and Chapelle (2008).

4-3. Boxplots showing differences in compositions of 121 groundwater samples from 117 wells in Wayne County, Pennsylvania, 2013-14, grouped by ranges in specific conductance (SC) given in units of microsiemens per centimeter of 40 to $<150(n=34), 150$ to $<300(n=70), 300$ to $<450(n=9)$, and 450 to $670(n=4)$

4-4. Boxplots showing distribution of principal component scores for 121 groundwater samples from 117 wells in Wayne County, Pennsylvania, 2013-14, classified by pH class interval as "acidic" $(5.4<\mathrm{pH}<6.4, \mathrm{n}=29)$, "neutral" $(6.5<\mathrm{pH}<7.4, \mathrm{n}=32)$, "alkaline" $(7.5<\mathrm{pH}<7.9, \mathrm{n}=25)$, and "very alkaline" (8.0<pH $<9.4, n=9)$; redox class interval "anoxic" $(n=25)$, "mixed" ( $n=1)$, and "oxic" ( $n=95)$; and specific conductance (SC) given in units of microsiemens per centimeter of 40 to $<150(n=34), 150$ to $<300$ $(n=70), 300$ to $<450(n=9)$, and 450 to $670(n=4)$

4-5. Boxplots showing differences in compositions of 121 groundwater samples from 117 wells in Wayne County, Pennsylvania, 2013-14, for five major topographic settings classified as ridges $(n=13)$, upper slopes $(n=0)$, and gentle slopes $(n=45)$, lower slopes $(n=11)$, and valleys $(n=22)$ on the basis of the 30-meter digital elevation model and criteria reported by Llewellyn (2014).

4-6. Map showing location and topographic setting of 121 groundwater samples from 117 wells in Wayne County, Pennsylvania,2013-14, for five major topographic index classifications-ridges, upper slopes, gentle slopes, lower slopes, and valleys - on the basis of the 30-meter digital elevation model and criteria reported by Llewellyn (2014). (ridges, $n=13$; upper slopes, $n=30$; gentle slopes, $n=45$; lower slopes, $n=11$; valleys, $n=22$ ). 


\section{Tables}

1. Maximum concentrations reported for selected inorganic constituents in oil and gas well brines or flowback waters in Pennsylvania.

2. Pre-drill lists of constituents recommended by the Pennsylvania Department of Environmental Protection (2012; 2014c) for analysis in private water supply wells prior to gas drilling

3. Minimum, median, and maximum of chemical and physical properties measured in the field, and concentrations of total dissolved solids, major ions, nutrients, and bacteria determined in the laboratory for water samples collected from 89 wells in Wayne County, Pennsylvania, July-September 2014

4. Minimum, median, and maximum concentrations of trace elements and metals determined in the laboratory for water samples collected from 89 wells in Wayne County, Pennsylvania, July-September 2014.

5. Minimum, median, and maximum concentrations of selected radioactive constituents determined in the laboratory for water samples collected from 89 wells in Wayne County, Pennsylvania, July-September 2014

6. Reporting levels and drinking-water standards for man-made organic compounds determined in the laboratory for water samples collected from 89 wells in Wayne County, Pennsylvania, July-September 2014

7. Minimum, median, and maximum concentrations of methane, ethane, and propane determined in the laboratory for water samples collected from 89 wells in Wayne County, Pennsylvania, July-September 2014

8. Concentrations of methane and ethane determined by two laboratories for water samples collected from 8 wells in Wayne County, Pennsylvania, July-September 2014

9. Major factors in principal components analysis model controlling the chemistry of groundwater, Wayne County, Pennsylvania, 2013-14.

10. Location, depth, and construction characteristics for 89 wells sampled in Wayne County, Pennsylvania, July-September 2014.

11. Field measurements and results of laboratory analyses for major and minor ions, nutrients, bacteria, trace metals, radioactivity, radon-222, and dissolved gases for water samples collected from 89 wells in Wayne County, Pennsylvania, July-September 2014.

12. Results of dissolved gas analysis and isotopic characterization of methane by Isotech Laboratories, Inc., for water samples collected from 16 wells in Wayne County, July-September 2014

A1-1. Minimum, median, and maximum of well characteristics, chemical properties measured in the field, and concentrations of total dissolved solids, major ions, nutrients, and selected hydrocarbon gases determined in the laboratory for water samples collected from 34 wells in Wayne County, Pennsylvania, 2011 and 2013

A1-2. Minimum, median, and maximum dissolved trace constituent concentrations and total gross alpha- and gross beta-particle, and radon-222 radioctivities determined in the laboratory for water samples collected from 34 wells in Wayne County, Pennsylvania, 2011 and 2013. 
A2-1. Methods used for determination of dissolved major ions, trace constituents, nutrients, and alkalinity by the U.S. Geological Survey National Water Quality Laboratory

A2-2. Methods and reporting levels used for determination of gross alpha and beta radioactivity, and radon-222 by the U.S. Geological Survey National Water Quality Laboratory.....

A2-3. Methods used for determination of major ions, trace constituents, and constituents determined by contract laboratories for Wayne County, Pennsylvania, groundwater samples collected in 2014 . .104

A3-1. Results of quality assurance and quality control analyses for six replicate well-water samples from Wayne County, Pennsylvania, 2014 106

A3-2. Comparison of field measurements and laboratory analysis for properties and constituents determined in water from four wells sampled in both 2013 and 2014

A4-1. Spearman rank correlation coefficient $(r)$ matrix for constituents and physical properties in 121 groundwater samples from 117 wells in Wayne County, Pennsylvania, 2013 and 2014 


\section{Conversion Factors and Datums}

\begin{tabular}{|c|c|c|}
\hline Multiply & By & To obtain \\
\hline \multicolumn{3}{|c|}{ Length } \\
\hline inch (in.) & 2.54 & centimeter $(\mathrm{cm})$ \\
\hline inch (in.) & 25.4 & millimeter $(\mathrm{mm})$ \\
\hline foot (ft) & 0.3048 & meter $(\mathrm{m})$ \\
\hline mile $(\mathrm{mi})$ & 1.609 & kilometer (km) \\
\hline \multicolumn{3}{|c|}{ Area } \\
\hline acre & 0.4047 & hectare (ha) \\
\hline acre & 0.004047 & square kilometer $\left(\mathrm{km}^{2}\right)$ \\
\hline square mile $\left(\mathrm{mi}^{2}\right)$ & 259.0 & hectare (ha) \\
\hline square mile $\left(\mathrm{mi}^{2}\right)$ & 2.590 & square kilometer $\left(\mathrm{km}^{2}\right)$ \\
\hline \multicolumn{3}{|c|}{ Volume } \\
\hline gallon (gal) & 3.785 & liter (L) \\
\hline gallon (gal) & 0.003785 & cubic meter $\left(\mathrm{m}^{3}\right)$ \\
\hline \multicolumn{3}{|c|}{ Flow rate } \\
\hline gallon per minute (gal $/ \mathrm{min})$ & 0.06309 & liter per second $(\mathrm{L} / \mathrm{s})$ \\
\hline inch per year (in/yr) & 25.4 & millimeter per year $(\mathrm{mm} / \mathrm{yr})$ \\
\hline \multicolumn{3}{|c|}{ Pressure } \\
\hline atmosphere, standard (atm) & 101.3 & kilopascal $(\mathrm{kPa})$ \\
\hline bar & 100 & kilopascal $(\mathrm{kPa})$ \\
\hline inch of mercury at $60^{\circ} \mathrm{F}$ (in $\mathrm{Hg}$ ) & 3.377 & kilopascal $(\mathrm{kPa})$ \\
\hline \multicolumn{3}{|c|}{ Radioactivity } \\
\hline picocurie per liter $(\mathrm{pCi} / \mathrm{L})$ & 0.037 & becquerel per liter $(\mathrm{Bq} / \mathrm{L})$ \\
\hline \multicolumn{3}{|c|}{ Specific capacity } \\
\hline $\begin{array}{l}\text { gallon per minute per foot } \\
[(\mathrm{gal} / \mathrm{min}) / \mathrm{ft})]\end{array}$ & 0.2070 & $\begin{array}{l}\text { liter per second per meter } \\
{[(\mathrm{L} / \mathrm{s}) / \mathrm{m}]}\end{array}$ \\
\hline \multicolumn{3}{|c|}{ Hydraulic gradient } \\
\hline foot per mile (ft/mi) & 0.1894 & meter per kilometer $(\mathrm{m} / \mathrm{km})$ \\
\hline
\end{tabular}

Temperature in degrees Celsius $\left({ }^{\circ} \mathrm{C}\right)$ may be converted to degrees Fahrenheit $\left({ }^{\circ} \mathrm{F}\right)$ as follows: ${ }^{\circ} \mathrm{F}=\left(1.8 \times{ }^{\circ} \mathrm{C}\right)+32$

Temperature in degrees Fahrenheit $\left({ }^{\circ} \mathrm{F}\right)$ may be converted to degrees Celsius $\left({ }^{\circ} \mathrm{C}\right)$ as follows:

$$
{ }^{\circ} \mathrm{C}=\left({ }^{\circ} \mathrm{F}-32\right) / 1.8
$$

Vertical coordinate information is referenced to the North American Vertical Datum of 1988 (NAVD 88).

Horizontal coordinate information is referenced to the North American Datum of 1983 (NAD 83).

Elevation, as used in this report, refers to distance above the vertical datum. 


\section{Supplemental Information}

Specific conductance is given in microsiemens per centimeter at 25 degrees Celsius $(\mu \mathrm{S} / \mathrm{cm}$ at $\left.25^{\circ} \mathrm{C}\right)$.

Concentrations of chemical constituents in water are given in either milligrams per liter (mg/L) or micrograms per liter $(\mu \mathrm{g} / \mathrm{L})$.

Activities for radioactive constituents in water are given in picocuries per liter (pCi/L).

Results for measurements of stable isotopes of an element (with symbol E) in water, solids, and dissolved constituents commonly are expressed as the relative difference in the ratio of the number of the less abundant isotope ( $\mathrm{E}$ ) to the number of the more abundant isotope of a sample with respect to a measurement standard.

\section{Abbreviations}

$\begin{array}{ll}\text { AMCL } & \text { Alternate maximum contaminant levels } \\ \text { EPA } & \text { U.S. Environmental Protection Agency } \\ \mathbf{M C L} & \text { Maximum contaminant level } \\ \mathbf{\mu g} / \mathbf{L} & \text { Micrograms per liter } \\ \mathbf{\mu S} / \mathbf{c m} \text { at } 25^{\circ} \mathbf{C} & \text { Microsiemens per centimeter at 25 degrees Celsius } \\ \mathbf{m g} / \mathbf{L} & \text { Milligrams per liter } \\ \text { PADEP } & \text { Pennsylvania Department of Environmental Protection } \\ \mathbf{P C i / L} & \text { Picocuries per liter } \\ \text { ROE } & \text { Residue on evaporation } \\ \text { SMCL } & \text { Secondary maximum contaminant level } \\ \text { TKN } & \text { Total Kjeldahl nitrogen } \\ \text { USGS } & \text { U.S. Geological Survey } \\ \text { VOC } & \text { Volatile organic compound }\end{array}$





\title{
Baseline Assessment of Groundwater Quality in Wayne County, Pennsylvania, 2014
}

\author{
By Lisa A. Senior, Charles A. Cravotta, III, and Ronald A. Sloto
}

\section{Abstract}

The Devonian-age Marcellus Shale and the Ordovicianage Utica Shale, geologic formations which have potential for natural gas development, underlie Wayne County and neighboring counties in northeastern Pennsylvania. In 2014, the U.S. Geological Survey, in cooperation with the Wayne Conservation District, conducted a study to assess baseline shallow groundwater quality in bedrock aquifers in Wayne County prior to potential extensive shale-gas development. The 2014 study expanded on previous, more limited studies that included sampling of groundwater from 2 wells in 2011 and 32 wells in 2013 in Wayne County. Eighty-nine water wells were sampled in summer 2014 to provide data on the presence of methane and other aspects of existing groundwater quality throughout the county, including concentrations of inorganic constituents commonly present at low levels in shallow, fresh groundwater but elevated in brines associated with fluids extracted from geologic formations during shalegas development. Depths of sampled wells ranged from 85 to 1,300 feet (ft) with a median of $291 \mathrm{ft}$. All of the groundwater samples collected in 2014 were analyzed for bacteria, major ions, nutrients, selected inorganic trace constituents (including metals and other elements), radon-222, gross alpha- and gross beta-particle activity, selected man-made organic compounds (including volatile organic compounds and glycols), dissolved gases (methane, ethane, and propane), and, if sufficient methane was present, the isotopic composition of methane.

Results of the 2014 study show that groundwater quality generally met most drinking-water standards, but some wellwater samples had one or more constituents or properties, including arsenic, iron, $\mathrm{pH}$, bacteria, and radon-222, that exceeded primary or secondary maximum contaminant levels (MCLs). Arsenic concentrations were higher than the MCL of 10 micrograms per liter $(\mu \mathrm{g} / \mathrm{L})$ in 4 of 89 samples $(4.5$ percent $)$ with concentrations as high as $20 \mu \mathrm{g} / \mathrm{L}$; arsenic concentrations were higher than the Health Advisory level of $2 \mu \mathrm{g} / \mathrm{L}$ in 27 of 89 samples ( 30 percent). Total iron concentrations exceeded the secondary maximum contaminant level (SMCL) of 300 $\mu \mathrm{g} / \mathrm{L}$ in 9 of 89 samples (10 percent). The $\mathrm{pH}$ ranged from 5.4 to 9.3 and did not meet the SMCL range of greater than 6.5 to less than 8.5 in 27 samples ( 30 percent); 22 samples had $\mathrm{pH}$ values less than 6.5 , and 5 samples had $\mathrm{pH}$ values greater than 8.5. Total coliform bacteria were detected in 22 of 89 samples (25 percent); Escherichia coli were detected in only 2 of those 22 samples. Radon-222 activities ranged from 25 to 7,400 picocuries per liter $(\mathrm{pCi} / \mathrm{L})$, with a median of $2,120 \mathrm{pCi} / \mathrm{L}$, and exceeded the proposed drinking-water standard of $300 \mathrm{pCi} / \mathrm{L}$ in 86 of 89 samples ( 97 percent); radon-222 activities were higher than the alternative proposed standard of $4,000 \mathrm{pCi} / \mathrm{L}$ in 12 of 89 samples (13.5 percent).

Water from 8 of the 89 wells ( 9 percent) had concentrations of methane greater than the reporting level of 0.24 milligrams per liter $(\mathrm{mg} / \mathrm{L})$ with the detectable methane concentrations ranging from 0.74 to $9.6 \mathrm{mg} / \mathrm{L}$. Of 16 replicate samples submitted to another laboratory with a lower reporting level of $0.0002 \mathrm{mg} / \mathrm{L}, 15$ samples had detectable methane concentrations that ranged from 0.0011 to $9.7 \mathrm{mg} / \mathrm{L}$. Of these 15 samples, low levels of ethane $(0.00032$ to $0.0017 \mathrm{mg} / \mathrm{L})$ were detected in 6 of 7 samples with methane concentrations greater than $0.75 \mathrm{mg} / \mathrm{L}$. The isotopic composition of methane in 6 of 8 samples with sufficient dissolved methane (about $1 \mathrm{mg} / \mathrm{L}$ ) for isotopic analysis is consistent with a predominantly thermogenic methane source (sample carbon isotopic ratio $\delta^{13} \mathrm{C}_{\mathrm{CH} 4}$ values ranging from -56.36 to -45.97 parts per thousand (\%) and hydrogen isotopic ratio $\delta \mathrm{D}_{\mathrm{CH} 4}$ values ranging from -233.1 to $-141.1 \%$ ). However, the low levels of ethane relative to methane indicate that the methane may be of microbial origin and subsequently underwent oxidation. Isotopic compositions indicated a possibly mixed thermogenic and microbial source (carbon dioxide reduction process) for the methane in 1 of the 8 samples $\left(\delta^{13} \mathrm{C}_{\mathrm{CH} 4}\right.$ of -63.72 and $\delta \mathrm{D}_{\mathrm{CH} 4}$ of $-192.3 \%$ ) and potential oxidation of microbial and (or) thermogenic methane in the remaining sample $\left(\delta^{13} \mathrm{C}_{\mathrm{CH} 4}\right.$ of -46.56 and $\delta \mathrm{D}_{\mathrm{CH} 4}$ of $-79.7 \%$ ).

Groundwater samples with relatively elevated methane concentrations (near or greater than $1 \mathrm{mg} / \mathrm{L}$ ) had a chemical composition that differed in some respects $(\mathrm{pH}$, selected major ions, and inorganic trace constituents) from groundwater with relatively low methane concentrations (less than $0.75 \mathrm{mg} / \mathrm{L}$ ). The seven well-water samples with the highest methane concentrations (from about 1 to $9.6 \mathrm{mg} / \mathrm{L}$ ) also had among the 
highest $\mathrm{pH}$ values ( 8.1 to 9.3 , respectively) and the highest concentrations of sodium, lithium, boron, fluoride, arsenic, and bromide. Relatively elevated concentrations of some other constituents, such as barium, strontium, and chloride, commonly were present in, but not limited to, those well-water samples with elevated methane.

Groundwater samples with the highest methane concentrations had chloride/bromide ratios that indicate mixing with a small amount of brine ( 0.02 percent or less, by volume) similar in composition to that reported for gas and oil well brines in Pennsylvania. Most other samples with low methane concentrations (less than about $1 \mathrm{mg} / \mathrm{L}$ ) had chloride/bromide ratios that indicate predominantly man-made sources of chloride, such as road salt, septic systems, and (or) animal waste. Although naturally occurring brines may originate from deeper parts of the aquifer system, the man-made sources are likely to affect shallow groundwater.

Geochemical modeling showed that the water chemistry of samples with elevated $\mathrm{pH}$, sodium, lithium, bromide, and alkalinity could result from dissolution of calcite (calcium carbonate) combined with cation exchange and mixing with a small amount of brine. Through cation exchange reactions (which are equivalent to processes in a water softener) calcium ions released by calcite dissolution are exchanged for sodium ions on clay minerals. The spatial distribution of groundwater compositions generally shows that (1) relatively dilute, slightly acidic, oxygenated, calcium-carbonate type waters tend to occur in the uplands along the western border of Wayne County; (2) waters of near neutral $\mathrm{pH}$ with the highest amounts of hardness (calcium and magnesium) generally occur in areas of intermediate altitudes; and (3) waters with $\mathrm{pH}$ values greater than 8 , low oxygen concentrations, and the highest arsenic, sodium, lithium, bromide, and methane concentrations can occur in deep wells in uplands but most frequently occur in stream valleys, especially at low elevations (less than about 1,200 ft above North American Vertical Datum of 1988) where groundwater may be discharging regionally, such as to the Delaware River. Thus, the baseline assessment of groundwater quality in Wayne County prior to gas-well development shows that shallow (less than about $1,000 \mathrm{ft}$ deep) groundwater is generally of good quality, but methane and some constituents present in high concentrations in brine (and produced waters from gas and oil wells) may be present at low to moderate concentrations in some parts of Wayne County.

\section{Introduction}

Wayne County, in northeastern Pennsylvania (fig. 1), is underlain by the Marcellus Shale and, at greater depths, the Utica Shale. These formations are being developed in western and northern Pennsylvania for natural gas using unconventional methods that involve hydrofracturing. The Marcellus
Shale is present from depths less than approximately 2,000 feet ( $\mathrm{ft}$ ) to more than 7,000 ft below land surface in Wayne County (Sloto, 2014), and the Utica Shale is present thousands of feet below the Marcellus Shale. All residents of largely rural Wayne County rely on groundwater as a source of water supply. Drilling and hydraulic fracturing of horizontal natural gas wells used to develop the shale gas deposits have the potential to contaminate freshwater aquifers that provide drinking water and the base flow of streams (Kargbo and others, 2010; Kerr, 2010; U.S. Environmental Protection Agency, 2014). Since 2006, permits have been issued for 33 Marcellus Shale gas wells in Wayne County (Pennsylvania Department of Environmental Protection, 2014b). However, because of a drilling moratorium imposed by the Delaware River Basin Commission (DRBC) in 2010 (Delaware River Basin Commission, 2014), only nine vertical exploratory gas wells have been drilled in Wayne County (fig. 1) as of January 2014 (Pennsylvania Department of Environmental Protection, 2014a). No horizontal drilling has been done, and no well has been hydraulically fractured in Wayne County. In contrast, in neighboring Susquehanna County where the DRBC moratorium is not applicable, a total of 1,218 gas wells (fig. 1) have been drilled from 2005 through August 2015 (Pennsylvania Department of Environmental Protection, 2015a, b).

Without baseline water-quality data, it is difficult to determine the effects of natural-gas production activities on the shallow groundwater chemistry. This study, conducted by the U.S. Geological Survey (USGS) in cooperation with Wayne Conservation District, expands upon a preliminary baseline assessment of groundwater quality done in 2013 by USGS in cooperation with the Pennsylvania Department of Conservation and Natural Resources, Bureau of Topographic and Geologic Survey (also known as Pennsylvania Geological Survey).

The 2014 groundwater-quality assessment is intended to provide current data on the presence, concentrations, and distribution of methane, inorganic constituents, and selected man-made organic compounds in shallow groundwater (less than about 1,000 feet deep) in bedrock aquifers prior to shalegas production in Wayne County. Analyses were conducted for constituents recommended by the Pennsylvania Department of Environmental Protection $(2012 ; 2014 \mathrm{c})$ for testing of private wells in areas where gas drilling may occur in the future; other constituents were analyzed to provide a more comprehensive characterization of groundwater quality than the constituents on the basic pre-drill list. The data collected during the 2014 study described in this report and the previous 2013 study document groundwater quality in Wayne County. In addition to serving as a baseline for future evaluations that might determine the effect of shale-gas development or other landuse changes on groundwater quality, the assessment also may be used to evaluate overall general groundwater quality in the county and identify constituents in local drinking water that may pose a health risk. 


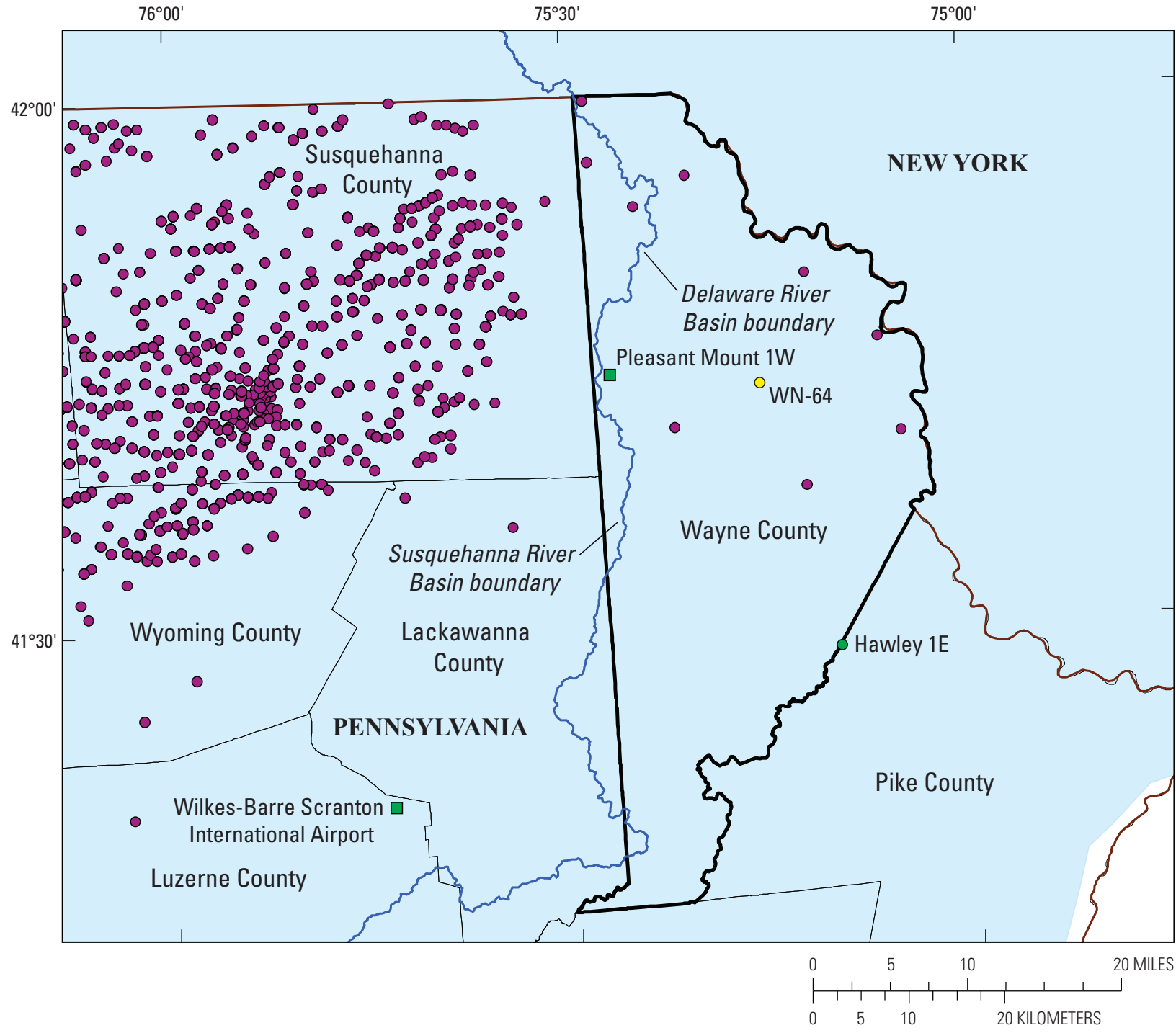

EXPLANATION
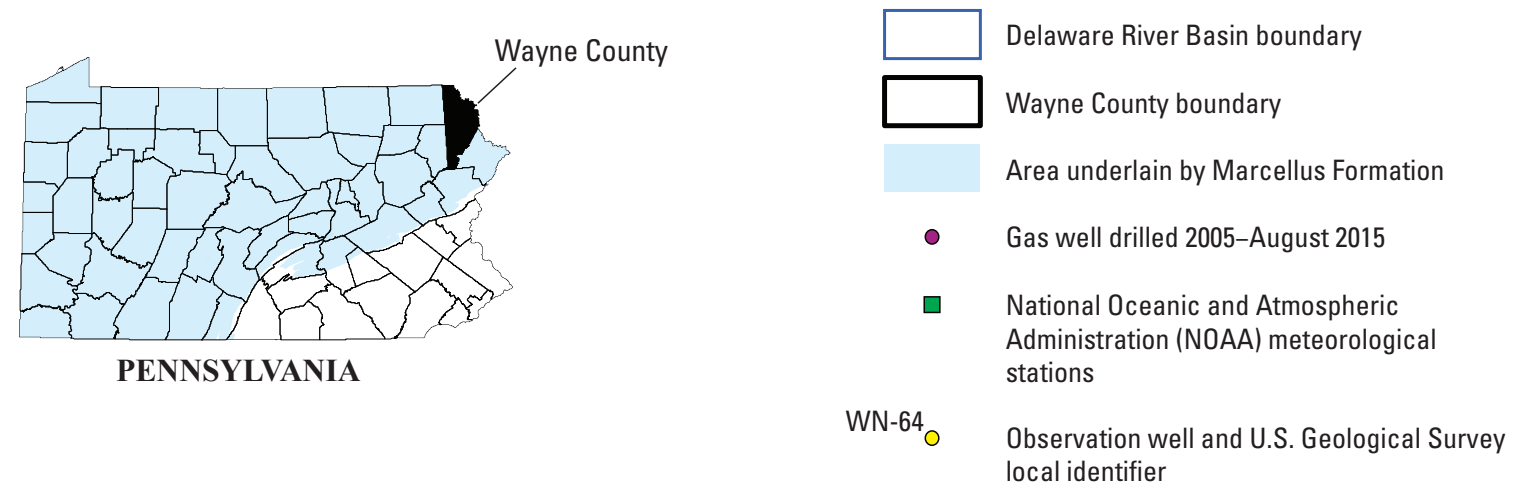

Figure 1. Location of Wayne County, Pennsylvania, and gas wells drilled from 2005 through August 2015. Gas well data from Pennsylvania Department of Environmental Protection (2015a). 


\section{Purpose and Scope}

This report presents analytical data for water samples collected from 89 domestic wells sampled in Wayne County during summer 2014. The water samples were analyzed for chemical and physical properties, and a suite of constituents including nutrients, major ions, trace elements and metals, radioactivity, selected man-made organic compounds, bacteria, radon-222, and methane and other dissolved hydrocarbon gases. The groundwater-quality data and summary statistics are presented to provide a pre-gas-well drilling baseline and compared to drinking-water standards to identify existing water-quality problems. The isotopic composition of methane in groundwater samples with sufficient methane to perform the analysis is compared to reported compositions for methane of thermogenic or biogenic origins.

Relations among constituents are described to provide insight into common presence of, and geochemical controls on, selected constituents, including those that pose health risks at elevated concentrations, such as arsenic, and others of concern, such as methane. Data evaluated in this report include results for 32 wells sampled in 2013 (Sloto, 2014) and results for 89 wells sampled in 2014 for this study. Statistical tests are used to identify groupings of constituents. Geochemical controls on the solubility of selected trace elements are shown in illustrations in relation to $\mathrm{pH}$ and oxidation-reduction conditions. Piper diagrams are presented to show the types of groundwaters in Wayne County. Use of chloride/bromide ratios to identify sources of chloride is discussed. Results of geochemical modeling, including mineral dissolution, ionexchange, and mixing with brine, are shown in illustrations to provide an explanation of the observed chemical compositions of groundwater samples. The spatial distribution of selected constituents is displayed on maps to illustrate the spatial patterns and to indicate the possible role of hydrogeologic setting on the presence of elevated concentrations of constituents of concern.

\section{Description of Study Area}

Wayne County, which occupies 750.5 square miles in northeastern Pennsylvania (fig. 1), is rural with a 2013 estimated population of 51,548 (U.S. Census Bureau, 2014). Seasonal dwellings (summer or vacation homes) made up 35.5 percent of housing units in the county in 2010 (Wayne County Planning Commission, 2010). In 2008, 65 percent of Wayne County was forested (Wayne County Planning Commission, 2010). Approximately 22 percent of the county was devoted to agriculture with about 11 percent of the land in pasture or brushland and 12.4 percent in cropland. About 8 percent of the county was developed with 6.2 percent of the land classified as residential and 0.9 percent classified as commercial.

\section{Physiography and Geologic Setting}

Most of Wayne County is in the Glaciated Low Plateau Section (fig. 2) of the Appalachian Plateaus Physiographic Province. A small part of western Wayne County is in the Anthracite Valley Section (fig. 2) of the Ridge and Valley Physiographic Province. The Glaciated Low Plateau Section is characterized by low to moderately high rounded hills and broad to narrow valleys, all of which have been modified by glacial erosion and deposition. Swamps and peat bogs are common. The Anthracite Valley Section is a canoe-shaped valley with irregular to linear hills and is enclosed by a steepsloped mountain rim. The southern tip of the county is in Glaciated Pocono Plateau Section (fig. 2) of the Appalachian Plateaus Physiographic Province, which is characterized by broad, undulatory upland surfaces with dissected margins (Sevon, 2000).

Wayne County is underlain by bedrock of Devonian and Pennsylvanian ages nearest the land surface (figs. 2 and 3). Alluvium and glacial outwash and drift overlie the bedrock. Geologic mapping is more recent and detailed in the southern half of the county than in the northern half. Most of the bedrock units that crop out in Wayne County are members of the Catskill Formation of Devonian age, as described briefly below. Sloto (2014) provides more detailed descriptions of the geologic formations of Devonian and Pennsylvania age in Wayne County.

Beds of the Catskill Formation in the vicinity of Wayne County are reported to be nearly flat-lying but generally dipping slightly (less than about 10 degrees) to the northwest (Sevon and others, 1989; Harrison and others, 2004).

Underlying these units are the Devonian-age Trimmers Rock Formation, Mahantango Formation, and Marcellus Shale (fig. 3). Depth to the Marcellus Shale ranges from less than about 2,000 ft below land surface in southern Wayne County to more than 7,000 ft below land surface in western Wayne County (Sloto, 2014). Two of three deep wells drilled in nearby Pike County for natural gas exploration during 1958-71 penetrated the Marcellus Shale at depths of 5,500 to $7,500 \mathrm{ft}$ below land surface, and the deepest of the three penetrated the Ordovician-age Utica Formation (another formation with potential for shale-gas development) at depth of about 13,000 feet below land surface (Sevon and others, 1989).

The Catskill Formation of Devonian age in the northern half of Wayne County was mapped by White (1881) and has not been differentiated into the individual members that make up the Catskill Formation. The Catskill Formation (undifferentiated) underlying the northern half of Wayne County consists of a succession of sandstone, siltstone, and shale with some conglomerate. In the southern half of Wayne County, various members of the Catskill Formation have been identified and mapped (fig. 3), including the Walcksville, Long Run, Packerton, Poplar Gap, and Duncannon Members (Berg and 


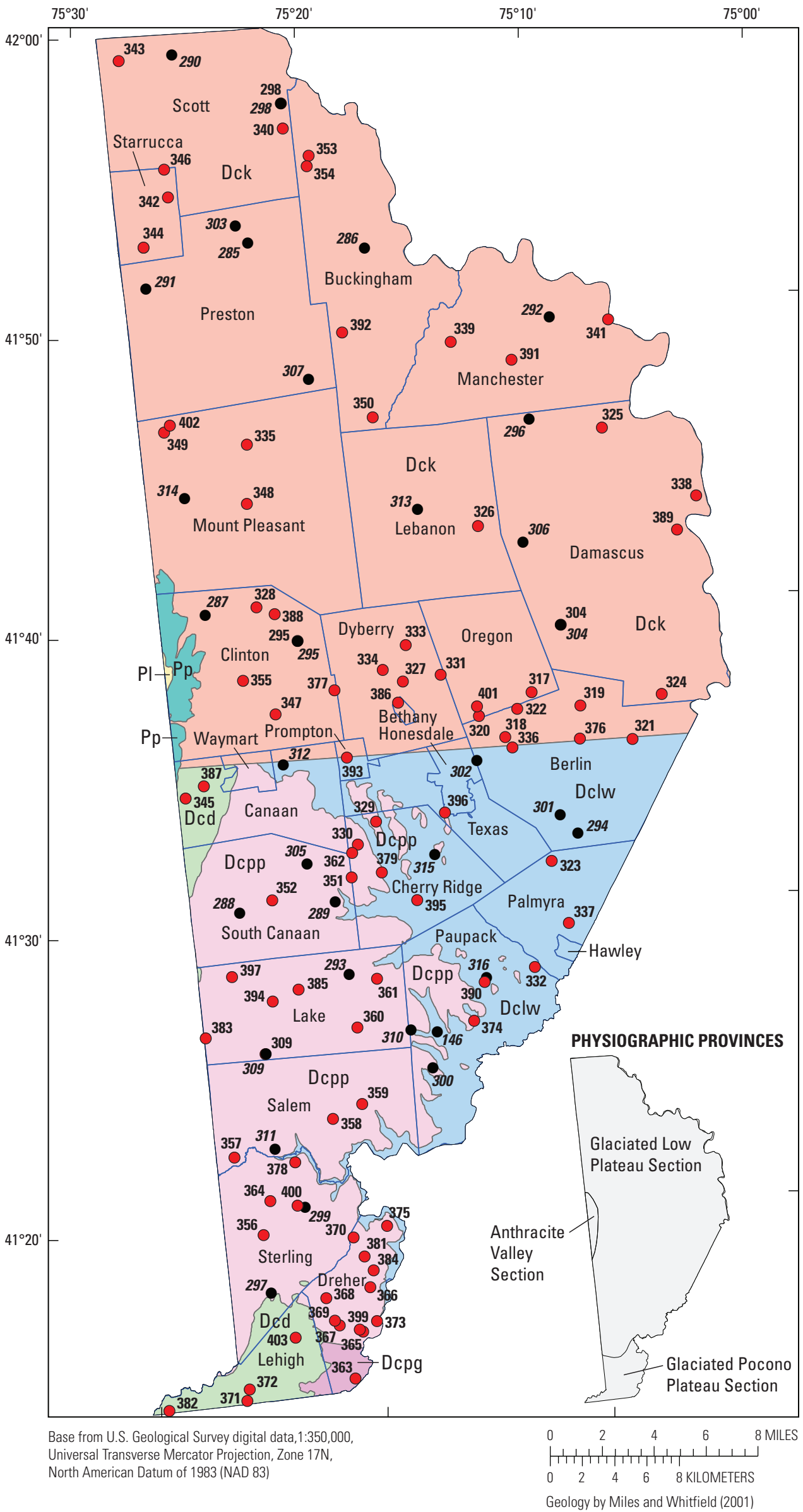

\section{EXPLANATION} GEOLOGY

$\mathrm{Pp}$ Llewellyn Formation

PI Pottsville Formation

Dck Catskill Formation, undifferentiated

Dcd Duncannon Member of Catskill

Dcd Formation

Poplar Gap Member of Catskill Formation

Poplar Gap and Packerton Members Dcpp of Catskill Formation, undivided

Dong Run and Walcksville Members of Catskill Formation, undivided

Municipality (township or borough)

325 Well sampled in 2014 and local well number (prefix WN- omitted)

296 Well sampled in 2013 and local well number (prefix WN- omitted)

Figure 2. Physiography, geology of the bedrock closest to land surface, and location of sampled wells in 2013 and 2014 in Wayne County, Pennsylvania. 


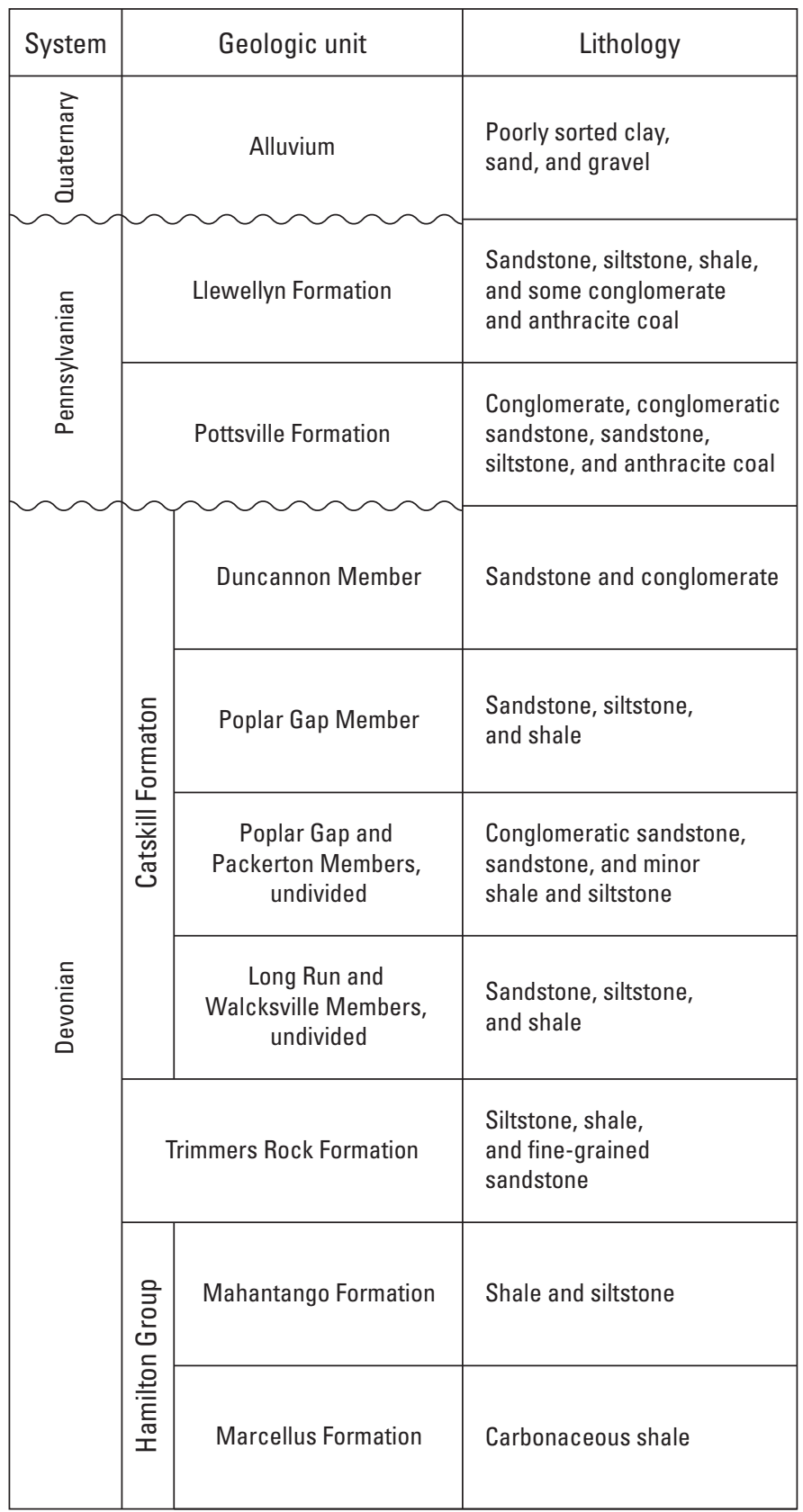

Figure 3. Stratigraphic correlation chart for Devonian-age and younger geologic units, Wayne County, Pennsylvania.

others, 1977; Sevon and others, 1975). These geologic units consist of sandstone, siltstone, and shale. The Poplar Gap Member is reported to have calcareous cementation in the base of some sandstone beds (Sevon and others, 1975). The Packerton and Duncannon Members include conglomerate or conglomeratic sandstone. A small area on the western edge of Wayne County is underlain by the Pottsville and Llewellyn Formations of Pennsylvanian age; these formations are composed of conglomerate, sandstone, siltstone, and shale, with some anthracite coal (Taylor, 1984). 


\section{Hydrogeologic Setting}

The sedimentary bedrock units that underlie Wayne County form fractured-rock aquifers that are recharged locally by precipitation. Annual precipitation varies throughout the county with higher total precipitation measured at meteorological stations at higher elevations; long-term (30-year normal) total annual precipitation is about 49.5 inches (in.) at Pleasant Mount $1 \mathrm{~W}$ meteorological station (elevation 1,800 ft above NAVD 88 ) in western Wayne County and about 42.9 in. at Hawley 1E meteorological station (elevation $890 \mathrm{ft}$ above NAVD 88) in eastern Wayne County (National Oceanic and Atmospheric Administration, 2015) (fig. 1). Precipitation falls approximately evenly throughout the year, although recharge rates differ seasonally because frozen ground can inhibit recharge during winter months and evapotranspiration reduces recharge during warm spring and summer months of the growing season. The seasonal pattern in net recharge rates is reflected in annual fluctuations in long-term (about 27 years, 1987 to 2014) daily median groundwater levels in observation well WN-64 in Wayne County (fig. 1), a 52-ft deep well completed in glacial deposits. Each year, generally rising water levels occur during 2 periods (March to mid-May and October to mid-November), indicating net positive recharge, and generally flat to declining water levels occur during 2 periods (mid-November to March and June through September), indicating reduced to negligible recharge (fig. 4). During this study, groundwater levels measured in long-term observation well WN-64 were slightly greater than the long-term daily median in July 2014 but fell to slightly below the long-term daily median by October 2014 (fig. 4). From June through August 2014, reported precipitation was lower than the longterm normal at Pleasant Mount $1 \mathrm{~W}$ meteorological station but near or slightly above average at Hawley $1 \mathrm{E}$ meteorological station; total monthly precipitation was about 3 in. lower than

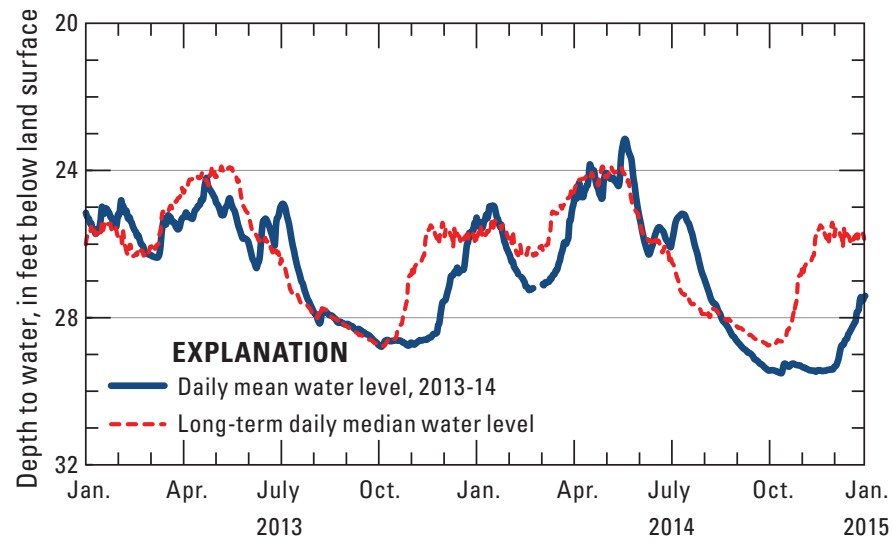

Figure 4. Observed daily mean water levels during 2013-14 and long-term (1987-2014) daily median water levels in an observation well WN-64, Wayne County, Pennsylvania. (Data from the U.S. Geological Survey National Water Information database.) long-term normal at both meteorological stations in September 2014 (National Oceanic and Atmospheric Administration, 2015). Thus, the groundwater-level and precipitation data indicate that the hydrologic conditions during 2014 were similar but slightly drier than long-term average or median conditions.

The groundwater flow system in Wayne County is thought to consist of local, intermediate, and regional components, with topography affecting directions of local and intermediate flow, as described in studies of nearby counties and in other areas of the Appalachian Plateau region (Carswell and Lloyd, 1979; Davis, 1989; Reese, 2014). Shallow- to intermediate-depth fresh groundwater flows from recharge areas at higher elevations and discharges locally and regionally into streams at lower evelations as base flow. In Wayne County, groundwater likely discharges regionally to the largest streams, including the Delaware River, which forms the northeastern border, and the Lackawaxen River, which flows in a southeastern direction across the center of Wayne County (fig. 5A). The surface-water divide between the Susquehanna River Basin to the west and the Delaware River Basin to the east lies near and along the western border of Wayne County (fig. 1), which is also the area of highest elevation in the county (figs. 5A, B).

Most wells in Wayne County currently are completed in fractured bedrock aquifers rather than the overlying unconsolidated glacial deposits. However, in earlier periods in Wayne County (1930s), many domestic wells were reported to have been completed in the unconsolidated glacial deposits (Lohman, 1937, p. 276). In the Catskill Formation, wells completed in sandstones are reported to have larger yields than wells completed in red shales (Lohman, 1937, p. 276).

\section{Previous Investigations}

Prior to 2011, little to no publicly available, qualityassured data had been collected to describe baseline groundwater quality in Wayne County in relation to the constituents listed by the Pennsylvania Department of Environmental Protection ( PADEP) in 2012 for pre-drill testing (Pennsylvania Department of Environmental Protection, 2012). Lohman (1937) presents limited historical waterquality data for a few wells in the county. As part of a regional assessment of wells on the National Park Service (NPS) lands, two wells in northern Wayne County near the Delaware River in the NPS Upper Delaware Scenic and Recreation River area were sampled by USGS in 2011 and analyzed for a suite of trace constituents and methane gas (Eckhardt and Sloto, 2012). In 2013, 32 additional wells throughout Wayne County were sampled by USGS (fig. 2) for a preliminary baseline assessment of groundwater quality that included analyses for 2012 PADEP pre-drill constituents, additional major ions, trace metals, radon-222, gross alpha- and gross-beta particle radioactivity, hydrocarbon gases methane and ethane, and isotopic composition of methane for samples with sufficient methane concentrations (Sloto, 2014). Results of the 2011 and 2013 sampling (Sloto, 2014), which are limited to concentrations 
$\boldsymbol{A}$

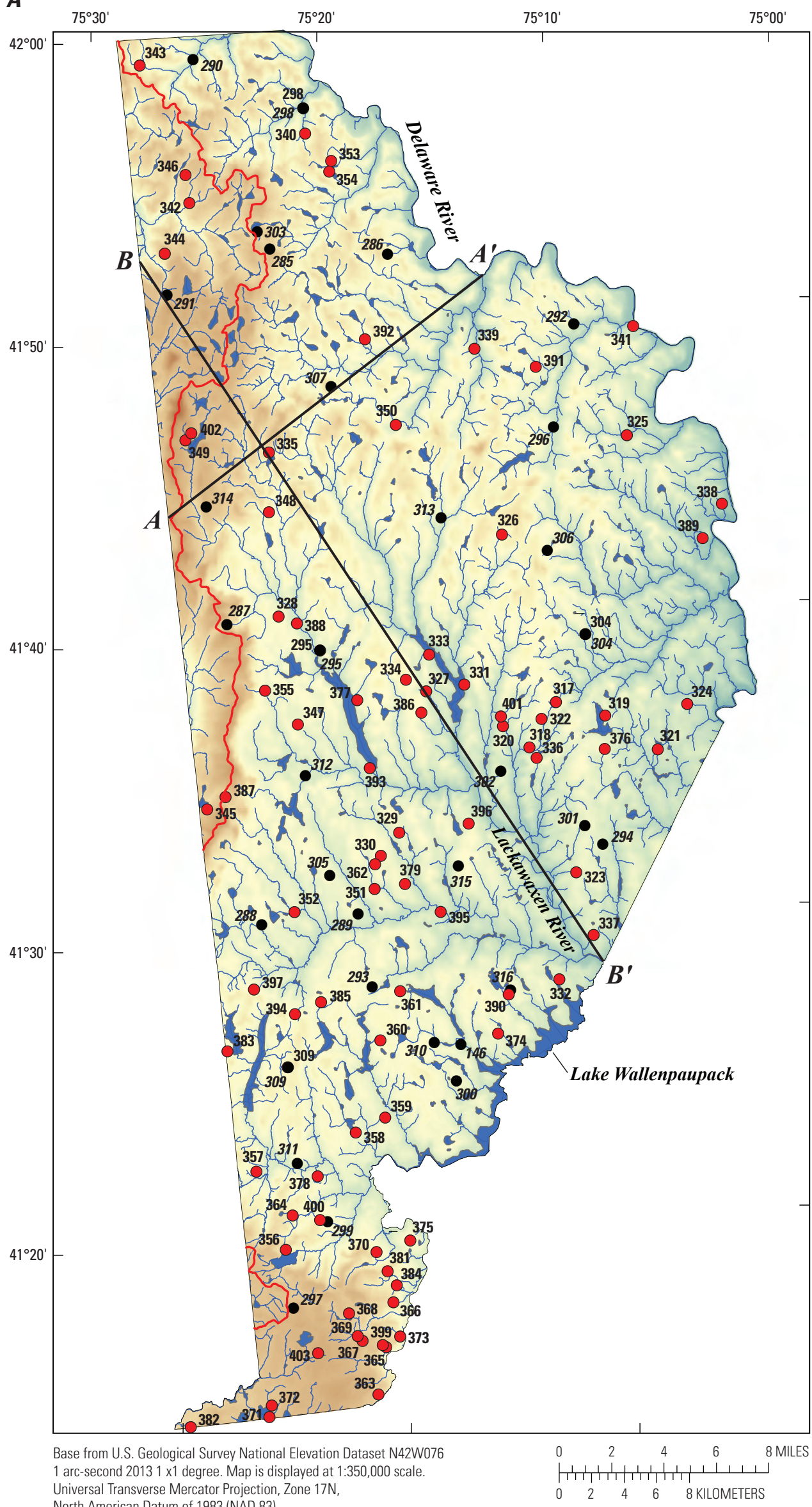

\section{EXPLANATION}

Land-surface elevation above NAVD 88

- High: 807 meters (2,648 feet)

- Mid: 446 meters (1,463 feet)

Low: 201 meters (659 feet)

Major river basin boundary

Stream or lake

${\underline{A} \quad \boldsymbol{A}^{\prime}}^{\prime}$ Transect

325 Well sampled in 2014 and local well number (prefix WN- omitted)

296. Well sampled in 2013 and local well number (prefix WN- omitted)

Figure 5. A, Land-surface elevation, streams, and location of wells sampled for baseline groundwater quality assessments in Wayne County, Pennsylvania, during 2013 and 2014, B, transect $A-A^{\prime}$ showing land-surface elevation, and $C$, transect B-B' showing land-surface elevation. Transect A-A' originates near the highest elevations and divide between Delaware and Susquehanna River Basins in western Wayne County. 


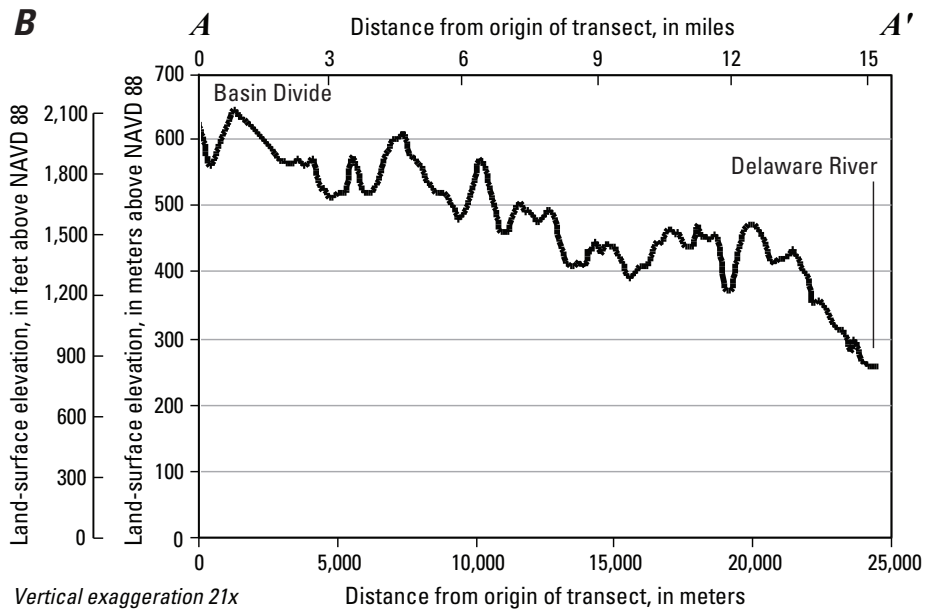

Figure 5. A, Land-surface elevation, streams, and location of wells sampled for baseline groundwater quality assessments in Wayne County, Pennsylvania, during 2013 and 2014, $B$, transect $\mathrm{A}-\mathrm{A}^{\prime}$ showing land-surface elevation, and $C$, transect $B-B$ ' showing land-surface elevation. Transect $A-A^{\prime}$ originates near the highest elevations and divide between Delaware and Susquehanna River Basins in western Wayne County.-Continued

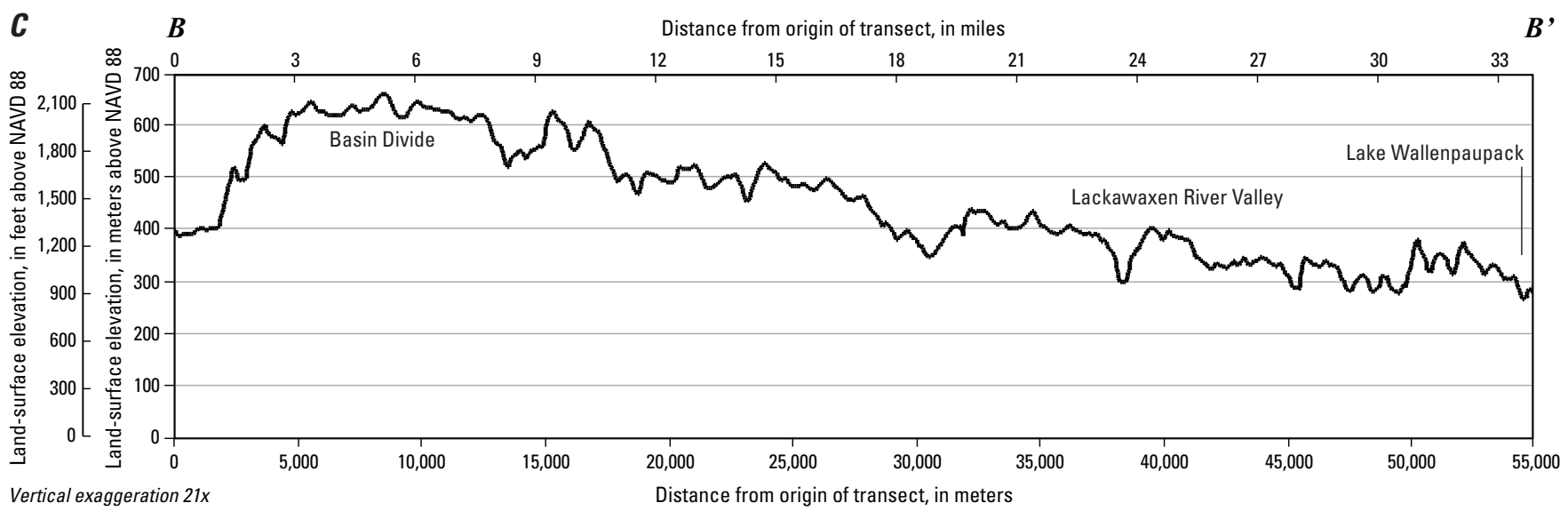

of dissolved inorganic constituents (because samples were filtered before analysis) and are partially summarized in Appendix 1 (tables A1-1 and A1-2), indicate four conditions: (1) groundwater quality in Wayne County meets drinkingwater standards for most constituents analyzed, although arsenic, sodium, and $\mathrm{pH}$ did not meet standards in some well samples; (2) arsenic concentrations in 3 of 34 well-water samples ( 9 percent) exceeded the maximum contaminant level (MCL) of 10 micrograms per liter $(\mu \mathrm{g} / \mathrm{L})$, and these elevated arsenic concentrations are associated with samples that have a pH greater than 8; (3) methane was detectable in most of the samples at low (less than $1 \mu \mathrm{g} / \mathrm{L}$ ) to moderate concentrations [as much as about 3 milligrams per liter $(\mathrm{mg} / \mathrm{L})$ ]; and (4) methane present in concentrations sufficient for isotopic analysis (equal to or greater than about $1 \mathrm{mg} / \mathrm{L}$ ) had isotopic compositions that were similar to methane of thermogenic or mixed thermogenic-microbial origin, where thermogenic methane is consistent with a deeply buried gas source, such as the Marcellus Shale, and microbial gas is consistent with biodegradation of organic compounds in the aquifer materials and soil.

\section{Methods of Sample Collection and Analysis}

To provide current data on the occurrence and spatial distribution of methane and various inorganic and man-made organic constituents in groundwater used for water supply in Wayne County, 89 domestic wells throughout Wayne County were sampled during summer 2014. The selected laboratory analyses were intended to determine baseline groundwater concentrations of methane and inorganic constituents, including radionuclides, that are commonly present in elevated concentrations in brines that, when disturbed, contribute to flowback fluids generated as a result of drilling and hydraulicfracturing activities (table 1). Water samples were collected once per site from 89 domestic wells from July through September 2014 and analyzed to characterize their physical properties and chemical characteristics. Samples were analyzed for all constituents on the 2012 PADEP pre-drill basic constituent list (table 2) and the PADEP modified pre-drill list as of 2014 (Pennsylvania Department of Environmental 
Protection, 2014c). Analyses also were conducted for additional major ions, trace constituents, selected man-made compounds [volatile organic compounds (VOCs), glycols, and alcohols], and dissolved gases, including methane, ethane, and radon-222. The analyses performed on samples collected in 2014 were more comprehensive than those done on the 32 well-water samples collected in 2013 (Sloto, 2014). The 2014 data extend the 2013 data on groundwater quality in Wayne County by providing greater spatial and chemical characterization of constituents, including determination of both total and dissolved concentrations of major ions, selected metals and trace elements, and additional man-made organic compounds.

\section{Selection of Sampling Locations}

Well locations were selected to provide spatially distributed data on groundwater quality in bedrock aquifers throughout Wayne County. Although the goal was to have an evenly spaced sample distribution, the availability of wells constrained the selection process. Most wells considered for inclusion in the study are domestic wells used to supply individual residences or other facilities in Wayne County. Criteria for well selection included availability of information about well construction from driller records submitted to the Pennsylvania Geological Survey and from well owners

Table 1. Maximum concentrations reported for selected inorganic constituents in oil and gas well brines or flowback waters in Pennsylvania.

[mg/L, milligrams per liter; $\mathrm{CaCO}_{3}$, calcium carbonate; $\mathrm{pCi} / \mathrm{L}$, picocuries per liter; --, no data]

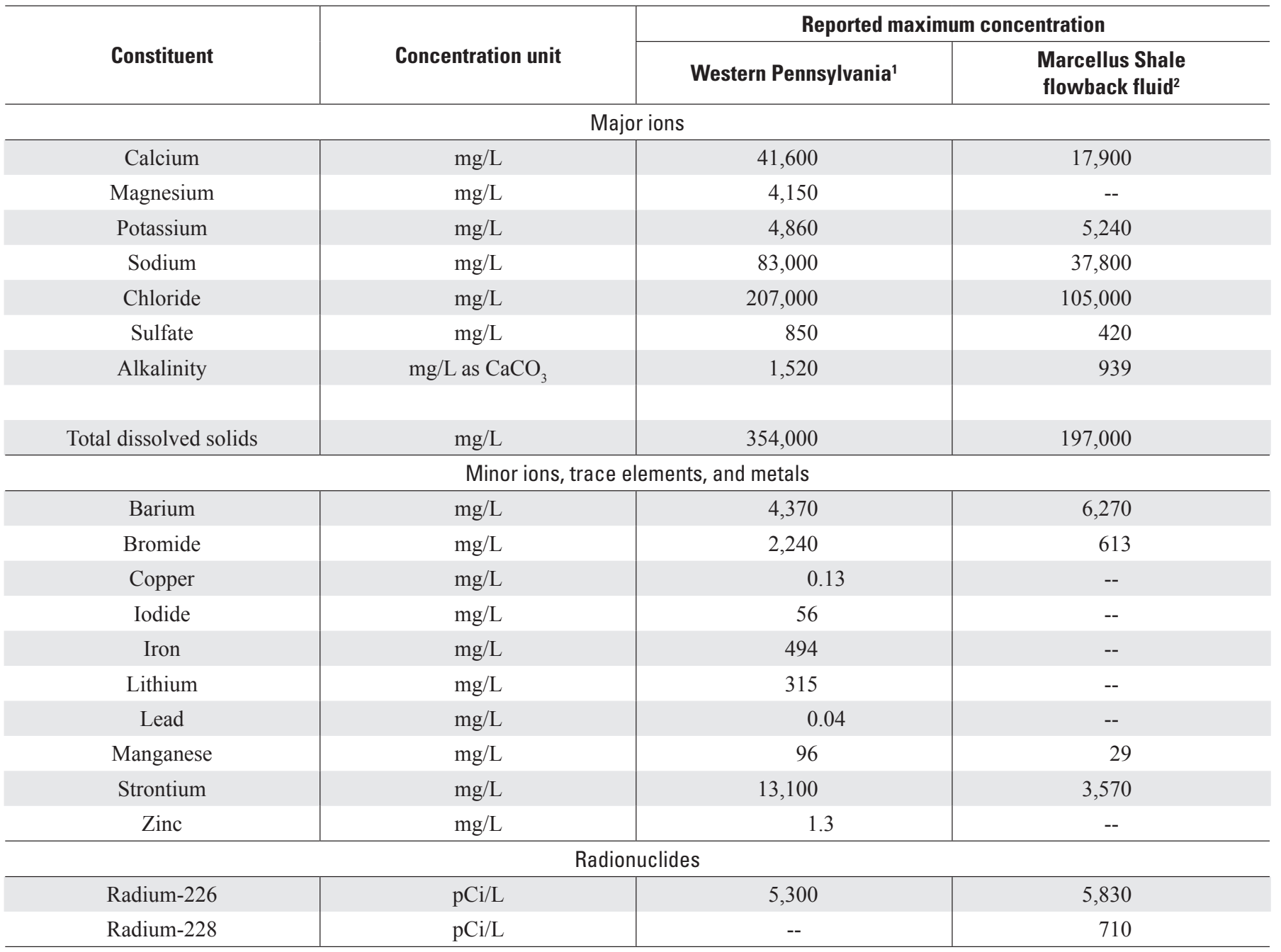

${ }^{1}$ Brines from oil and gas wells in Devonian- and Silurian-age rocks in Western Pennsylvania (Dresel and Rose, 2010).

${ }^{2}$ Data from Pennsylvania Department of Environmental Protection Bureau of Oil and Gas Management reported in Haluszczak and others (2013). 
or other sources. Additionally, the ability to obtain a rawwater sample from a well was a requirement. The Wayne Conservation District provided support in identifying wells and obtaining permission from well owners for the study.

Eighty-nine wells were selected for sampling in 2014 (fig. 2), 4 of which had been previously sampled in 2013 (WN-295, WN-298, WN-304, and WN-309). The four wells sampled in 2013 that were selected to be resampled in 2014 had relatively elevated $\mathrm{pH}$ (greater than 8.1) and detectable to relatively elevated (about 1 to $3 \mathrm{mg} / \mathrm{L}$ ) methane concentrations in 2013.
Depths and other characteristics of the 89 wells sampled in 2014 are listed in table 10 (at the back of the report). Wells sampled in 2014 range in depth from 85 to $1,300 \mathrm{ft}$, with a median depth of $291 \mathrm{ft}$, and have casing lengths that range from 14 to $223 \mathrm{ft}$, with a median length of $55 \mathrm{ft}$. For wells with known construction, most were completed as 6-inch-diameter open holes for which steel (or, less commonly, plastic) casing was extended into competent bedrock with the remainder of the borehole left open. Two wells (WN-354 and WN-342), which were 85 and $121 \mathrm{ft}$ in depth, respectively, were reported to be cased along the entire depth, a type of construction frequently used for wells in unconsolidated glacial deposits, so it

Table 2. Pre-drill lists of constituents recommended by the Pennsylvania Department of Environmental Protection (2012; 2014c) for analysis in private water supply wells prior to gas drilling.

[E. Coli, Escherichia Coli; PADEP, Pennsylvania Department of Environmental Protection]

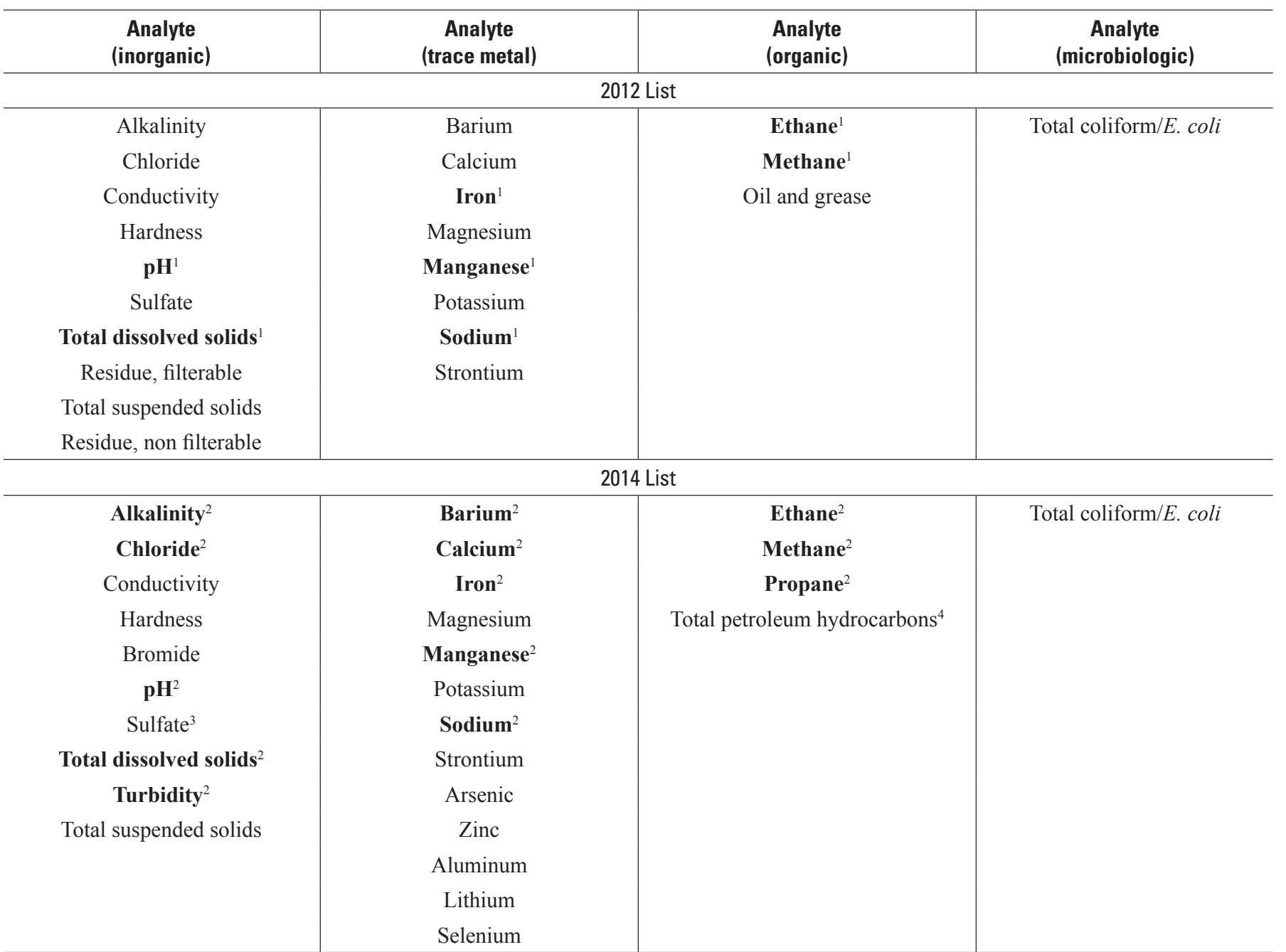

${ }^{1}$ PADEP (2012) recommendations note that "As a minimum, a homeowner wishing to have their private well tested should analyze for these parameters."

${ }^{2}$ PADEP (2014) recommendations note that "As a minimum, a homeowner wishing to have their private well tested should analyze for these parameters."

${ }^{3}$ Consider where coal formations are present.

${ }^{4}$ Consider in western Pennsylvania’s oil-producing regions. 
is possible that the wells draw water from the glacial deposits. Other wells are reported or presumed to be completed in bedrock on the basis of well construction information. All wells are in areas underlain by various mapped and undifferentiated members of the Devonian-age Catskill Formation. Characteristics of wells sampled in 2013 are provided in Sloto (2014).

\section{Collection of Samples}

The USGS sampled the 89 wells using standard USGS field-sampling protocols. Samples were collected at an untreated tap, typically at a pressure tank or outside tap and before any filtration, water softening, or bacteriological treatment. Water samples were analyzed in the field for unstable physical and chemical properties (such as temperature) and dissolved oxygen (DO), then shipped overnight to laboratories for analysis for major ions, nutrients, metals, trace elements, gross alpha and beta radioactivity, bacteria, man-made organic compounds, and dissolved gases. All well-water samples were collected and processed for analysis by methods described in USGS manuals for the collection of water-quality data (U.S. Geological Survey, variously dated).

Sampling was conducted at each well using the following steps. The existing submersible well pump was turned on and allowed to run. A raw-water tap was opened, and the water was allowed to flush to minimize possible effects of plumbing and ensure that the water was representative of the aquifer. The water was analyzed with a multi-parameter probe meter for temperature, specific conductance (SC), $\mathrm{pH}$, and DO concentration. After the values of these characteristics stabilized, sample bottles were filled according to USGS protocols (U.S. Geological Survey, variously dated). Samples were collected through Teflon tubing attached to the raw-water tap, which avoided all water-treatment systems.

Unfiltered (whole-water) samples were collected for determination of physical properties and for analyses for radioactivity, dissolved gases, and the PADEP pre-drill constituents to obtain total concentrations. Samples for analyses for concentrations of dissolved nutrients, major ions, metals, and trace elements were filtered through a field-rinsed 0.45-micrometer pore-size cellulose capsule filter. To prevent sample degradation, nitric acid was added to the major cation, metals, and trace-element samples. No preservative was added to samples for analysis of major anions and dissolved nutrients. Samples for analysis for total Kjeldahl nitrogen (TKN), and oil and grease, were preserved with sulfuric acid. Samples for VOC analysis were preserved with ascorbic acid. Samples for radon analysis were obtained through an in-line septum with a gas-tight syringe to avoid atmospheric contact. Samples for dissolved gases were obtained through Teflon tubing placed in bottles that were filled and stoppered while submerged to avoid atmospheric contact.
The samples were stored on ice in coolers and shipped by overnight delivery to the following laboratories: (1) the USGS National Water Quality Laboratory in Denver, Colorado, for analysis for major ions, nutrients, total dissolved solids (TDS), metals, and trace elements in filtered water samples, and radon; (2) TestAmerica, Inc., in Richland, Washington, a USGS contract laboratory, for analysis of gross alpha- and gross beta-particle activity (also referred to as gross alpha and gross beta radioactivity); (3) Isotech Laboratories, Inc., in Champaign, Illinois, a USGS contract laboratory, for analysis of dissolved methane, other dissolved gases including hydrocarbons, and isotopes of hydrogen and carbon in methane; and (4) Mountain Research, LLC, in Altoona, Pennsylvania, a Wayne Conservation District contract laboratory accredited by PADEP Bureau of Laboratories, for analysis of unfiltered samples using approved drinking-water methods of (a) the PADEP pre-drill constituents, including major ions, iron, manganese, barium, strontium, TDS, total suspended solids (TSS), total solids, oil and grease, and total coliform and Escherichia Coli (E.Coli) bacteria and (b) selected man-made organic compounds (VOCs, glycols. alcohols), TKN, and dissolved methane, ethane, and propane gases. The Mountain Research laboratory subcontracted analyses for barium, manganese, VOCs, and alcohols to Seewald Laboratories, Inc., in Williamsport, Pennsylvania; methane, ethane, and propane to Environmental Service Laboratories, Inc., in Indiana, Pennsylvania; and glycols, chloride, sulfate, and TKN to Fairways Laboratories, Inc., in Altoona, Pennsylvania.

Water samples containing a sufficient concentration of methane (as measured in replicate samples by Environmental Service Laboratories, Inc.), generally greater than $0.9 \mathrm{mg} / \mathrm{L}$, were submitted to Isotech Laboratories, Inc., for determination of (1) the isotopic composition of methane with analysis for the stable carbon isotopes ${ }^{12} \mathrm{C}$ and ${ }^{13} \mathrm{C}$ and the stable hydrogen isotopes ${ }^{1} \mathrm{H}$ (protium) and ${ }^{2} \mathrm{H}$ (deuterium) and (2) dissolved gases (oxygen, nitrogen, carbon dioxide, carbon monoxide, hydrogen, and argon) and selected hydrocarbons (methane, ethane, propane, and higher-carbon alkanes).

\section{Analysis of Chemical, Physical, and Other Characteristics and Reporting Units}

Analytical methods and reporting levels for constituents analyzed by PADEP Bureau of Laboratories accredited laboratories and other laboratories are listed in Appendix 2 (table A2-3). Descriptions of analytical methods for constituents analyzed by the USGS National Water Quality Laboratory (NWQL) are available from the U.S. Geological Survey (2014a). Reporting levels for constituents analyzed by NWQL are listed in Appendix 2 (tables A2-1 and A2-2). The analytical results are available online from the USGS National Water Information System (U.S. Geological Survey, 2014b). 
The water-quality constituents have various reporting units. Reporting units for dissolved and total chemical concentrations are milligrams per liter $(\mathrm{mg} / \mathrm{L})$ or micrograms per liter $(\mu \mathrm{g} / \mathrm{L}) ; 1 \mathrm{mg} / \mathrm{L}$ is approximately equal to 1 part per million, and $1 \mu \mathrm{g} / \mathrm{L}$ is approximately equivalent to 1 part per billion. One $\mathrm{mg} / \mathrm{L}$ equals $1,000 \mu \mathrm{g} / \mathrm{L}$. Reporting units for bacteria are the most probable number of colonies per 100 milliliters of sample (MPN/100 mL). Reporting units for radioactivity are picocuries per liter ( $\mathrm{pCi} / \mathrm{L})$, a commonly used unit for radioactivity in water. One picocurie (pCi) equals $10^{-12}$ Curie or $3.7 \times 10^{-2}$ atomic disintegrations per second. Activity refers to the number of particles emitted by a radionuclide. The rate of decay is proportional to the number of atoms present and inversely proportional to half-life, which is the amount of time it takes for a radioactive element to decay to one-half its original quantity. In gas samples analyzed by Isotech Laboratories, Inc., dissolved gas values were reported in terms of mole percent in headspace for the water sample, and also for methane as a dissolved concentration in units of $\mathrm{mg} / \mathrm{L}$.

Methane was the only hydrocarbon with sufficient mass in the Wayne County groundwater samples for isotopic carbon and hydrogen determination by Isotech Laboratories, Inc., using a method that involved initial separation of hydrocarbons followed by conversion into carbon dioxide and water for subsequent mass-spectrometric analysis and comparison to standards (Alan R. Langenfeld, Isotech Laboratories, Inc., written commun., 2012). The hydrocarbons were separated from the water sample by allowing gases to transfer into headspace; then gases were separated from each other using a gas chromatograph and channeled into a combined combustioncollection unit. The combined combustion-collection unit uses quartz combustion tubes filled with cupric oxide to convert the hydrocarbons into carbon dioxide and water, which are then collected and purified for isotopic analysis. The carbon dioxide component derived from the methane was transferred into Pyrex tubing and sealed for mass spectrometric analysis to determine the ${ }^{13} \mathrm{C} /{ }^{12} \mathrm{C}$ isotopic ratio. Isotopic ratios for the sample are reported relative to the isotopic ratio of a standard, where the difference (delta or $\delta$ ) commonly is given in parts per thousand (ppt; also denoted as \%o) with positive values indicating enrichment of the heavier isotope and negative values indicating depletion of the heavier isotope. Thus, for $\mathrm{R}=$ ratio of heavier to lighter isotope, $\delta($ in $\% 0)=\left[\mathrm{R}_{\text {sample }} /\left(\mathrm{R}_{\text {standard }}-1\right)\right]^{*}(1,000)$. The carbon isotope ratio value of a sample relative to a standard $\left(\delta^{13} \mathrm{C}\right)$ is reported in terms of the \%o notation with respect to the Vienna Pee Dee Belemnite (VPDB) standard. The water component derived from the methane was sealed into Pyrex tubing along with a measured quantity of zinc for hydrogen isotope analysis. Each sample tube was reacted in a heating block at 500 degrees Celsius $\left({ }^{\circ} \mathrm{C}\right)$ for 35 minutes to generate hydrogen gas. Once the sample had been reacted, the ${ }^{2} \mathrm{H} /{ }^{1} \mathrm{H}$ isotopic ratio was determined by mass spectrometric analysis and is reported in terms of the parts per thousand notation $(\delta \mathrm{D})$ with respect to the Vienna Standard Mean Ocean Water (VSMOW) standard.

\section{Quality Control and Quality Assurance}

For quality control (QC), replicate samples collected from six wells (WN-321, 330, 346, 348, 356, and 368) and six field blanks were submitted to the laboratories for analysis. The QC replicate results are listed in Appendix 3 (table A3-1). None of the blanks contained detectable concentrations of any constituent, except for low values (near or below reporting levels) of radioactive constituents, which likely reflect the uncertainty in values measured near the reporting levels for those constituents (within method uncertainty) rather than sample contamination. Therefore, low concentrations (near reporting level) of radioactive constituents are to be interpreted with caution. Four of the six field-blank samples contained three radioactive constituents at low concentrations near but below the laboratory reporting levels of $3 \mathrm{pCi} / \mathrm{L}$ for gross alpha radioactivity, $4 \mathrm{pCi} / \mathrm{L}$ for beta radioactivity, and $20 \mathrm{pCi} / \mathrm{L}$ for radon-222. In one blank, gross alpha radioactivity counted at 72 hours was measured at $0.4 \mathrm{pCi} / \mathrm{L}$, and gross beta radioactivity counted at 72 hours was measured at $1.8 \mathrm{pCi} / \mathrm{L}$, although gross alpha and gross beta radioactivity counted at 30 days were less than the reporting level in the blank sampled. Gross alpha radioactivity counted at 72 hours was measured at $0.7 \mathrm{pCi} / \mathrm{L}$ in a second blank, and gross beta radioactivity counted at 72 hours was measured at $1.7 \mathrm{pCi} / \mathrm{L}$ in a third blank. In a fourth blank, radon-222 was measured at $19 \mathrm{pCi} / \mathrm{L}$.

The differences in concentrations between replicate paired samples varied on the basis of analyte group, and the relative magnitude of differences tended to be greatest when concentrations were lowest. The analytes with the largest relative differences [where the relative difference, in percent, is calculated as $[100 *(\mathrm{c} 1-\mathrm{c} 2) /((\mathrm{c} 1+\mathrm{c} 2) / 2)]$ in concentrations between the sample and its replicate were low-concentration analytes with concentrations near the laboratory reporting level. Typically, acceptable precision for many analyses is 5 percent. However, small absolute differences in reported concentrations between replicates can result in relative differences greater than 5 percent. For major ions, most relative differences were less than 5 percent. Only three ion replicates had a difference of more than plus or minus $( \pm) 5$ percent, and these were for low potassium and sodium concentrations. The difference between concentrations in replicate samples for metals and trace elements generally was less than 5 percent, but relative differences greater than 5 percent were apparent for a few total iron and total manganese concentrations, dissolved copper at low concentrations $(<10 \mu \mathrm{g} / \mathrm{L})$, and dissolved lithium at low concentrations $(<1.0 \mu \mathrm{g} / \mathrm{L})$. For example, one of the largest relative differences (70 percent) was for dissolved lithium. The difference in concentrations between the sample $(0.9 \mu \mathrm{g} / \mathrm{L})$ and the replicate sample $(0.16 \mu \mathrm{g} / \mathrm{L})$ is $0.74 \mu \mathrm{g} / \mathrm{L}$; these values are close to the laboratory reporting level $0.13 \mu \mathrm{g} / \mathrm{L}$ for dissolved lithium. Differences among replicates for gross alpha and gross beta radioactivity were commonly 10 to 20 percent, which reflects some intrinsic uncertainty in 
the analysis, particularly for results near the reporting level of $3 \mathrm{pCi} / \mathrm{L}$. Therefore, no corrective action to the analytical results was needed, but replicate results show that analytical uncertainty may be relatively greater for constituent concentrations near detection limits.

Results of replicate analyses for determination of bacteria show the maximum difference in the number of colonies between replicates was 9 for total coliform and 1 for E.Coli, but generally results of replicate analyses were consistent. All replicates had relatively low $(<20$ and $<3 \mathrm{MPN} / 100 \mathrm{~mL}$ for total coliform and E.Coli, respectively) to undetectable numbers of bacteria (Appendix 3). Two samples (one for $E$. Coli and one for total coliform) had a low-level detection and a non-detection in the replicate pair, which may be related to inherent variability in analyses for bacteria, especially at very low levels. Additional uncertainty in results of analyses for bacteria may have been introduced because the holding times (elapsed time from sample collection to sample preparation in the laboratory) exceeded the 6-hour limit used for compliance monitoring (although holding times were usually within the 24-hour limit used for routine monitoring).

Other QC checks on the accuracy of the data included computation of cation-anion balance, specific conductance (SC), and dissolved solids. These checks largely involve major ion concentrations. Differences in the sum of cation and anion milliequivalents

[calculated, in percent, as $100 *(\mathrm{C}-\mathrm{A}) /(\mathrm{C}+\mathrm{A})$,

where $\mathrm{C}$ is cation milliequivalents and $\mathrm{A}$ is anion

milliequivalents]

of 5 percent or less are considered good balances and indicate accurate determination of major ion concentrations. The Wayne County groundwater samples, using alkalinity determined in the field and laboratory, generally had cationanion balances that met this criterion. However, in a few cases, the cation-anion balances computed using field alkalinity had differences of greater than 5 percent, and in these cases, the field alkalinity did not match laboratory alkalinity, indicating that those field alkalinity values were likely inaccurate. Thus, on the basis of the cation-anion balance evaluation, the laboratory alkalinities were determined to be generally more reliable than field alkalinities, and consequently, laboratory alkalinity values were used in all subsequent data analysis. Generally, the field and laboratory measured values were in good agreement for $\mathrm{pH}$ and SC. Furthermore, the SC, which is measured with a meter in the field or laboratory, and TDS, which is measured in the laboratory as residue on evaporation (ROE) or computed from measured ion concentrations, were linearly related with strong correlation coefficients. The field and laboratory measured $\mathrm{SC}$ were equivalent to one another and to the computed SC on the basis of ionic conductivity contributions. Likewise, the measured TDS was equivalent to the computed TDS from the sum of ions (see figures in Appendix 3). These results indicate that field and laboratory measurements were consistent with one another and with the major ion analyses and, therefore, could be presumed to be accurate.

\section{Temporal Variability}

Samples were collected only once per site at most locations in 2014, and these groundwater-quality data from those samples are assumed to be representative for the purpose of evaluating spatial distributions in water quality for this study. Overall, the distribution of groundwater quality, as inferred from the summary statistics (range and median values), was similar for one-time sampling of wells located throughout Wayne County for summer 2013 (32 wells) and summer 2014 ( 89 wells), regardless of differences in well locations and sampling period. The similarity between the 2013 and 2014 summary results indicates little temporal variability in general overall findings between the two summer sampling events conducted 1 year apart. However, groundwater quality may vary locally or regionally through time as a result of seasonal or annual differences in recharge, land use, or other factors. A 2-year study of 35 wells in Susquehanna County indicated that groundwater quality generally varies more spatially from well to well than temporally at a single well, although some changes in water quality in a single well may be relatively rapid if there is good hydraulic connection to the land surface or near surface where contaminants, such as road salt, have been applied (Rhodes and Horton, 2015). In a 1-year study of temporal variability in groundwater quality with monthly sampling of four wells in Pike County, large increases in salt concentrations related to road-salt application near the well head were measured in samples from one well during winter months, and smaller differences in water quality were measured in samples from all wells during the study period (Senior, 2014).

To provide some assessment of possible differences in water quality in individual wells through time, four of the sites sampled in summer 2013 that had elevated concentrations of methane or other unusual characteristics were sampled again, approximately 1 year later, in summer 2014. Results of the analyses for four wells sampled in 2013 and 2014 were compared (see Appendix 3, table A3-2). Comparisons were limited to the constituents analyzed in the 2013 samples, which included dissolved major ions, nutrients, selected trace metals, gross alpha and gross beta radioactivity, radon-222, and methane. Although most constituents were similar in value (within 5 percent), all four samples had at least one constituent for which values from 2013 and 2014 differed by more than 20 percent. Minor differences may be expected owing to analytical uncertainty; however, differences greater than 20 percent for constituents occurring in concentrations substantially higher than the reporting level may represent real differences in water quality between samples collected at different times. In particular, the 2013 and 2014 samples collected from well WN-304 had more constituents that differed to a greater extent than samples from the other wells. This well was not typical of the domestic wells sampled throughout Wayne County. According the field technician that interviewed the owner and collected the samples, well WN-304 had been 
used solely for irrigation, did not have any treatment, and had been out of service for several years prior to sampling because of its poor yield and quality. Concentrations of some alkali metal cations (sodium and lithium) decreased from 2013 to 2014, whereas concentrations of alkaline earth metal cations (calcium, magnesium, strontium, barium) increased from 2013 to 2014, indicating that the samples may represent different mixtures of waters from more than one water-bearing zone in well WN-304 because compositional differences could not be attributed to variations in water treatment prior to sampling, such as a water softener that would remove calcium and similar ions.

Evaluation of these limited results for four wells sampled twice 1-year apart indicate that temporal variability in water quality may be a factor to consider when establishing baseline water quality. Additional monitoring through time beyond the one-time sampling conducted for this assessment would be needed to determine seasonal or other types of variability in water quality.

\section{Graphical and Statistical Analyses}

Various graphical and statistical techniques were used in this study to compare water-quality data among different sites, to estimate natural and man-made sources of dissolved constituents, and to identify possible factors affecting the presence, concentration, spatial distribution, or transport of solutes in the aquifers in the study area. Scatter plots were created to investigate potential relations among $\mathrm{pH}$, selected constituent concentrations, and the saturation index (SI) values for minerals that may be sources or controls of the constituents. Major ion data were plotted on trilinear (Piper) diagrams (Appelo and Postma, 2005; Back, 1966; Hem, 1985) to illustrate the range of water composition of the samples collected for this study and to investigate possible processes, such as calcite dissolution, cation exchange, and mixing with road deicing salt or brine, that could produce the observed variations in major ions. The Piper diagrams were generated using the Geochemist's Workbench (Bethke and Yeakel, 2010).

In general, nonparametric, rank-based statistical approaches were used to accommodate non-normally distributed and censored data typical of most environmental samples (Helsel and Hirsch, 2002). Data for individual continuous variables, such as chemical concentrations, were censored to a common level, and censored values were set to a common reporting limit before ranks were computed for use in statistical tests. Relations between continuous variables were evaluated with scatter plots and correlation coefficients (Spearman's rho); distributions of continuous variables were compared among different sample classifications using notched boxplots (Velleman and Hoaglin, 1981; Helsel and Hirsch, 2002). Statistically significant $(\mathrm{p}<0.05)$ correlation coefficients and boxplots are presented in Appendix 4 (table A4-1). Where the median for a group is greater than the common reporting limit, it is displayed as a horizontal line within the box that is defined by the 25th and 75th percentiles for that group; otherwise, the median is displayed at the reporting limit. If the notched intervals around the medians for sample subsets do not overlap, the medians are statistically different at the 95-percent confidence interval.

Notched boxplots were constructed with P-STAT (P-STAT, Inc., 2008) to compare concentrations of major ions, trace elements, and other water quality variables among different subsets of the combined data for 2013 and 2014 on the basis of the $\mathrm{pH}$, specific conductance, redox variables, or topographic position index. The $\mathrm{pH}$ classes considered in this report were (1) acidic, $\mathrm{pH} 5.4$ to 6.4 ; (2) neutral, $\mathrm{pH} 6.5$ to 7.4; (3) alkaline, $\mathrm{pH} 7.5$ to 7.9 ; and very alkaline, $\mathrm{pH} 8.0$ to 9.4.

The specific conductance classes were (1) 40 to $<150$ microsiemens per centimeter at 25 degrees Celsius $\left(\mu \mathrm{S} / \mathrm{cm}\right.$ at $25^{\circ} \mathrm{C}$ ); (2) 150 to $<300 \mu \mathrm{S} / \mathrm{cm}$ at $25^{\circ} \mathrm{C}$; (3) 300 to $<450 \mu \mathrm{S} / \mathrm{cm}$ at $25^{\circ} \mathrm{C}$; and (4) 450 to $670 \mu \mathrm{S} / \mathrm{cm}$ at $25^{\circ} \mathrm{C}$. For the $\mathrm{pH}$ and $\mathrm{SC}$ classifications, the middle two groups represented approximately one-half and two-thirds of the data values, respectively. The redox classifications used in this report were based on concentration thresholds of McMahon and Chapelle (2008) but were simplified to consider only three major classes: (1) anoxic (DO $\leq 0.5 \mathrm{mg} / \mathrm{L}),(2) \operatorname{mixed}(\mathrm{DO}>$ $0.5 \mathrm{mg} / \mathrm{L}$ and either manganese $\geq 50 \mu \mathrm{g} / \mathrm{L}$ or iron $\geq 100 \mu \mathrm{g} / \mathrm{L})$, and (3) oxic (DO $>0.5 \mathrm{mg} / \mathrm{L}$, manganese $<50 \mu \mathrm{g} / \mathrm{L}$, and iron $<100 \mu \mathrm{g} / \mathrm{L}$ ). The topographic position index (TPI) was computed on the basis of the 30-meter digital elevation model and criteria reported by Llewellyn (2014) to indicate five potential classes for topographic setting - (1) ridge, (2) upper slope, (3) gentle slope, (4) lower slope, and (5) valley.

Principal components analysis (PCA), computed with SAS 9.2 (SAS Institute, Inc., 2012), was used to evaluate multivariate correlations among the elements in the regional groundwater dataset without prior classification. The goal was to identify important hydrochemical processes or master variables that could explain element associations and distributions (Joreskog and others, 1976; Drever, 1997; Thyne and others, 2004). The Spearman-rank correlation coefficient matrix for the groundwater dataset provided the standardized input for the PCA. Because the PCA model would exclude the entire record for any sample with a missing value, those constituents that were missing or those that were censored in more than 40 percent of the samples were excluded, including dissolved fluoride, organic nitrogen, and various trace elements. The PCA model was optimized with varimax rotation to maximize the differences among the principal components; only principal components with eigenvalues greater than unity, equivalent to correlations with a probability greater than or equal to 0.999, were retained (Joreskog and others, 1976; Thyne and others, 2004). Loadings for each constituent included in the PCA model are equivalent to the Spearman-rank correlation coefficient between that constituent and the principal component. To aid in interpretations, the scores for each principal component in the PCA model were compiled, then evaluated 
by correlation or graphical analysis with additional variables that had been excluded from the PCA, including lithology, land use, well depth, and chemical constituents. For simplification of displayed results, the loading values and Spearmanrank correlation coefficient values were multiplied by 100 and rounded. Significant correlation coefficients for the additional variables are displayed beneath the main PCA model results; only correlation coefficients with a probability greater than or equal to 0.999 are considered significant.

\section{Geochemical Modeling}

Quantitative geochemical modeling of inorganic constituents was done to assess the potential for geochemical factors to affect water quality. Aqueous speciation computations were conducted using the computer program PHREEQC (Parkhurst and Appelo, 2013) with the WATEQ4F thermodynamic database (Ball and Nordstrom, 1991) and cation-exchange equilibrium reactions as defined by Appelo and Postma (2005). The molal concentrations of aqueous species were used to estimate the ionic contributions to specific conductance (McCleskey and others, 2012). The mineral SI values for various major and trace minerals were used to indicate the potential for mineral dissolution and precipitation. If a mineral phase is undersaturated in groundwater (SI less than 0), that mineral phase (if present) has the potential to be dissolved by the groundwater. In contrast, if a mineral is supersaturated in groundwater (SI greater than 0), that mineral phase will not dissolve (if present), feasibly could precipitate, and thus be a limiting factor for the related dissolved constituent concentrations.

Inverse modeling with PHREEQC was used to evaluate mass-transfer processes that could feasibly produce the observed concentrations of constituents in the groundwater samples (Parkhurst and Appelo, 2013). The first series of models simulated reactions between rainfall or relatively dilute background water samples and ubiquitous silicate, oxide, carbonate, sulfate, and sulfide minerals that could produce the range of observed groundwater quality. Relatively dilute background water quality was estimated using groundwater from wells $\mathrm{WN}-371$ and $\mathrm{WN}-345$, which had specific conductance values of 80 and $40 \mu \mathrm{S} / \mathrm{cm}$ at $25^{\circ} \mathrm{C}$, respectively, and $\mathrm{pH}$ of 6.1 and 5.8, respectively. In addition to mineral dissolution and precipitation, the inverse models also considered the potential for cation exchange and mixing with brine to explain the observed compositions of various groundwater samples.

On the basis of predominant processes indicated by the inverse models, a series of forward reaction models was developed that simulated the progressive addition of calcite, road deicing salt, or brine to the dilute background water in order to illustrate the general trends in concentrations of major and minor ions. The chemical compositions indicated by the masstransfer models could then be plotted on graphs relative to the amount of solid reactant or brine added to the groundwater and on Piper diagrams and scatter plots showing the changes in $\mathrm{pH}$ or constituent concentration with reaction progress.

\section{Baseline Groundwater Quality in Wayne County}

The 2014 groundwater-quality assessment was intended to provide current data on the occurrence and concentrations of methane and a suite of inorganic constituents in groundwater in bedrock aquifers prior to shale-gas development in Wayne County. Many of the inorganic constituents selected for analysis may be present in elevated concentrations in naturally occurring brines and in flowback and produced waters associated with unconventional shale-gas development (table 1) and, therefore, are part of the PADEP pre-drill list of constituents recommended for assessment (table 2), but these same constituents are commonly present at low to moderate concentrations in shallow, fresh (non-saline) groundwater. Additionally, some of the inorganic constituents included in groundwater analyses for this study can be introduced by human activities not directly related to shale-gas production, such as use of road salt or onsite-wastewater disposal. In this report, the term "brine-related" refers to inorganic constituents present at high concentrations in brines but does not necessarily imply any direct contribution of brines to freshwater.

Dissolved constituents in groundwater may be derived from atmospheric, geologic, biologic, and man-made sources as the recharge and groundwater interacts with various materials along transport pathways. Solute concentrations can range widely depending on the presence of constituent elements in the source(s), the extent of contact between water and the source, the aqueous solubility and interactions among the dissolved elements, plus geochemical conditions such as $\mathrm{pH}$ and oxidation-reduction (redox) state that affect element form, mobility, and transport in the aqueous environment.

Major ions typically are derived by the dissolution of common minerals, including carbonates, silicates, oxides, sulfates, and sulfides, and their concentrations can be affected by ion exchange, redox processes, and mixing of freshwater with residual brines that remain in the aquifer matrix or that could be mobilized from deep sources. The concentrations of major ions, TDS, salinity, and SC of groundwater are directly related and generally expected to increase with progressive evaporation or mineral weathering (Hem, 1985). The concentrations of trace elements in solution may increase with TDS or SC, not only because of the release of trace constituents with the major ions dissolved from minerals, but because of the potential for increased displacement of adsorbed or exchangeable trace ions from mineral surfaces.

Major cations (positively charged ions such as calcium, magnesium, sodium, and potassium), major anions (negatively charged ions such as sulfate, chloride, fluoride, and bicarbonate), and nonionic solutes (uncharged solutes such as silica) typically are present in natural waters at concentrations greater than $1 \mathrm{mg} / \mathrm{L}$, whereas dissolved trace constituents (such as iron, manganese, zinc, lead, copper, nickel, vanadium, molybdenum, arsenic, selenium, radium, uranium, lithium, bromide) typically are present at concentrations less than 
$1 \mathrm{mg} / \mathrm{L}$ (Hem, 1985). Concentrations of DO range from less than $1 \mathrm{mg} / \mathrm{L}$ in geochemical environments in which oxygen is consumed through oxidation of organic compounds or minerals up to saturation concentrations of about $12 \mathrm{mg} / \mathrm{L}$ at $7.5^{\circ} \mathrm{C}$ (saturation concentration is $11.4 \mathrm{mg} / \mathrm{L}$ at $9.5^{\circ} \mathrm{C}$, the minimum measured groundwater temperature during 2014 sampling in Wayne County) in freshly recharged or organic-poor groundwater. Concentrations of nutrients (such as nitrogen and phosphorus compounds) typically range from less than $1 \mathrm{mg} / \mathrm{L}$ in most natural settings to greater than $1 \mathrm{mg} / \mathrm{L}$ because of manmade inputs. Although biological (biochemical) processes can affect the concentrations of nutrients and trace constituents in groundwater directly or indirectly because of changes to $\mathrm{pH}$ and redox, such processes generally have minor effects on major ion concentrations.

\section{Geochemical Controls on Selected Constituents in Groundwater}

Elevated concentrations of major and trace constituents in groundwater tend to be present locally or are associated with specific aquifer settings, particularly under (1) acidic (low $\mathrm{pH}$ ) or basic (high $\mathrm{pH}$ ) conditions where the solubilities and mobilities of many element species are increased (Langmuir, 1997), (2) reducing conditions where the dissolution of iron and manganese oxides can release adsorbed and coprecipitated metals (Langmuir, 1997; McMahon and Chapelle, 2008), or (3) conditions where residual brines may mix with freshwaters (Whittemore, 2007; Haluszczak and others, 2013).

Although the release of trace elements through mineral weathering is a natural process, accelerated mineral decomposition that accompanies the development of strongly acidic or reducing conditions could be a consequence of human activities. For example, groundwater acidification can result from the excavation and oxidation of sulfide minerals or the release of gaseous emissions containing sulfur or nitrogen oxides (acid rain), and groundwater reduction can result from the infiltration of organic wastes (septic systems) or overfertilization. Furthermore, some constituents may originate from industrial sources, man-made materials, or land applications. Thus, in order to determine constituent concentrations that may have been added to groundwater as a consequence of land-use or waste-disposal practices, natural background concentrations for specific geologic or environmental settings need to be established.

In order to identify geochemical environments where elevated concentrations of constituents may be present, waterquality conditions such as $\mathrm{pH}$ and redox state, and major ion composition, need to be characterized. For example, some trace elements and metals may be more soluble in acidic waters (such as copper and lead), whereas others may be more soluble in basic waters (such as arsenic as arsenate, and phosphorus as phosphate). Relative solubilities and tendency of selected trace elements and metals (as commonly occurring ions) to adsorb onto or desorb from iron oxides in relation to
$\mathrm{pH}$ are shown in Appendix 4 (fig. 4-2), which can be used to explain the presence of these constituents in aquifer settings such as that in Wayne County.

\section{Wayne County Groundwater Quality and Its Relation to Drinking-Water Standards}

Because groundwater is the main source of drinking water in Wayne County, assessment of groundwater quality relative to drinking-water standards is important. Naturally occurring constituents and constituents introduced by human activities may pose a risk to human health when present at certain concentrations in groundwater used for drinking-water supply. The U.S. Environmental Protections Agency (EPA) has established MCLs for many constituents in drinking water to protect human health (U.S. Environmental Protection Agency, 2012). These MCLs, also known as primary drinking-water standards, may be used as a guideline for private well owners but are mandatory for public drinking-water supplies. Other EPA non-regulatory drinking-water guidelines include Health Advisory (HA) levels, and secondary maximum contaminant levels (SMCLs). HA levels are listed by EPA for selected constituents that have no MCL or, in some cases, in addition to the MCL. SMCLs are listed for selected constituents that pose no known health risk but may have adverse aesthetic effects, such as staining or undesirable taste or odor (U.S. Environmental Protection Agency, 2012).

The concentrations of chemical constituents in the well-water samples were compared to established criteria for protection of human health, including the EPA MCLs and HAs (U.S. Environmental Protection Agency, 2012), also defined by USGS as health-based screening levels (HBSLs). Groundwater quality was also compared to SMCLs. Because water quality at a given location will vary temporally owing to natural hydrologic processes and seasonality, the assessment of water quality relative to established standards on the basis of samples collected only once from each well is limited to conditions at that time. Although not done for this study, constituent concentrations also could be evaluated with respect to a fraction (such as one-half) of the relevant human health criteria to allow for unknown but estimated variability related to seasonal changes, water use, analytical accuracy, and other factors.

Overall, the quality of the groundwater sampled in Wayne County in 2014 was generally within EPA drinking-water standards established for selected constituents and, therefore, considered to be very good. However, in some samples, the concentrations of certain constituents exceeded drinking-water standards and HAs (U.S. Environmental Protection Agency, 2012). Complete results for the 89 water samples are given in table 11 (back of report). Summary statistics for results are discussed in the following sections. The range of and median values for the water-quality characteristics measured in the 89 groundwater samples collected in 2014 are very similar to those determined for the 32 samples collected in 2013 (Appendix 1). 


\section{General Characteristics}

Water quality often is characterized in terms of general characteristics, such as $\mathrm{pH}$, conductivity, or hardness. Some of these characteristics, such as $\mathrm{pH}$, change after sample collection and, being unstable, typically are measured in the field at the time of sample collection. Summary statistics for chemical and physical properties measured in the field, in addition to measures of general water quality, are listed in table 3.

\section{Field measurements of $\mathrm{pH}$, Alkalinity, Specific} Conductance, and Dissolved Oxygen

Water temperature, $\mathrm{pH}$, and $\mathrm{DO}$ concentration are unstable properties and were determined in the field at the time a water sample was collected. Alkalinity and SC were both determined in the field and in the laboratory. Of the physical and chemical properties measured in the field, drinking-water standards have been established only for $\mathrm{pH}$, and results show that some samples have $\mathrm{pH}$ values that exceed SMCLs (table 3).

$\mathrm{pH}$ is a measurement of the activity of hydrogen ions in water and is expressed in logarithmic units with a $\mathrm{pH}$ of 7 considered neutral. Water with a $\mathrm{pH}$ less than 7 is acidic; water with a $\mathrm{pH}$ greater than 7 is basic (or alkaline). The $\mathrm{pH}$ of 89 water samples collected in Wayne County ranged from 5.4 to 9.3 ; the median $\mathrm{pH}$ was 7.3 (table 3). The $\mathrm{pH}$ of 27 of 89 samples (30 percent) was outside the EPA SMCL range of 6.5 to 8.5 (U.S. Environmental Protection Agency, 2012). Twenty of 89 samples (22 percent) had a pH less than 6.5 , and 7 of 89 samples ( 8 percent) had a $\mathrm{pH}$ greater than 8.5 (table 3 ). The spatial distribution of $\mathrm{pH}$ values in Wayne County groundwater is shown in figure 6 .

The alkalinity of a solution is a measure of the capacity for the solutes it contains to react with and neutralize acid and typically consists largely of carbonate and bicarbonate ions (Hem, 1985, p. 106). Alkalinity ranged from 10 to $202 \mathrm{mg} / \mathrm{L}$ as calcium carbonate $\left(\mathrm{CaCO}_{3}\right)$; the median concentration was $84 \mathrm{mg} / \mathrm{L}$ as $\mathrm{CaCO}_{3}$ (table 3). Alkalinity is related to the $\mathrm{pH}$ of a water sample. In general, water samples with a higher $\mathrm{pH}$ have a higher alkalinity (fig.7A).

Specific conductance is a measurement of the ability of water to conduct an electric current. Specific conductance ranged from 28 to $678 \mu \mathrm{S} / \mathrm{cm}$ at $25^{\circ} \mathrm{C}$; the median specific conductance was $192 \mu \mathrm{S} / \mathrm{cm}$ at $25^{\circ} \mathrm{C}$ (table 3). Specific conductance measured in the 89 water samples is linearly related to the TDS concentration, a measure of dissolved ionic concentrations, in the water sample $\left(r^{2}=0.94\right)$ (fig. 8). Specific conductance (and TDS) tended to increase as $\mathrm{pH}$ increased in the Wayne County groundwater samples (fig. 7B).

Concentrations of DO ranged from 0.1 to $10.7 \mathrm{mg} / \mathrm{L}$; the median concentration was $3.2 \mathrm{mg} / \mathrm{L}$ (table 3 ). The DO concentration was low, less than $0.5 \mathrm{mg} / \mathrm{L}$, in water samples from 18 (20 percent) of 89 wells (table 11 at back of report). Low DO concentrations are related to chemical or biochemical reactions that consume oxygen and may result in reducing conditions that promote the release of some metals. The chemical reactions that consume oxygen can be naturally occurring in soil or aquifer materials and are commonly associated with microbial activity or oxidation of selected minerals such as pyrite. In the groundwater samples collected in Wayne County, $\mathrm{DO}$ concentrations tend to decrease with increasing $\mathrm{pH}$; $\mathrm{DO}$ concentrations generally were highest in acidic (low $\mathrm{pH}$ ) water and lowest (less than $0.5 \mathrm{mg} / \mathrm{L}$ ) in alkaline water ( $\mathrm{pH}$ greater than 7.8) (fig. 7C). These relations indicate that consumption of oxygen increases as mineral weathering increases in groundwater.

\section{Total Dissolved Solids, Total Solids, Hardness, and Corrosivity}

Concentrations of TDS in the 89 water samples ranged from 24 to $370 \mathrm{mg} / \mathrm{L}$ and were all less than the SMCL of $500 \mathrm{mg} / \mathrm{L}$ (table 3). Total solids concentrations were similar to TDS, indicating that most constituents in the groundwater are present in dissolved form rather than particulate (or suspended) form. TDS concentrations often are used as a measure of salinity. Freshwater commonly is defined as having TDS concentrations less than $1,000 \mathrm{mg} / \mathrm{L}$ and saline water as having TDS concentrations greater than $1,000 \mathrm{mg} / \mathrm{L}$. In a regional study of the presence of saline water in the United States, depth to saline water (TDS greater than $1,000 \mathrm{mg} / \mathrm{L}$ ) was estimated to be greater than or equal to $1,000 \mathrm{ft}$ in northeastern Pennsylvania in the vicinity of Wayne County (Feth and others, 1965). On the basis of geophysical logs in similar hydrogeologic settings in Pike, Wayne, and Monroe Counties, the depth of freshwater circulation was estimated to be greater than $800 \mathrm{ft}$ below land surface in Monroe County, which is southeast of, and adjacent to, Wayne County (Carswell and Lloyd, 1979). Results from the 2014 sampling of the 89 wells with depths of as much as $1,300 \mathrm{ft}$ are consistent with these estimates of depth to saline water.

Hardness reflects the concentrations of calcium and magnesium ions, which are released into groundwater from the dissolution of calcium- and magnesium-bearing minerals. Hard water decreases lathering of soap and increases accumulation of mineral deposits in plumbing and cooking utensils. Hardness of the 89 well-water samples ranged from less than 1 to $170 \mathrm{mg} / \mathrm{L}$ as calcium carbonate $\left(\mathrm{CaCO}_{3}\right)$ with a median value of $74.5 \mathrm{mg} / \mathrm{L}$ as $\mathrm{CaCO}_{3}$ (table 3 ). Hard water has greater potential than soft water to form scale or encrustations on plumbing and fixtures. Using a common hardness classification (Dufor and Becker, 1964), the measured values (sum of dissolved calcium and magnesium concentrations) indicate that 35 (39 percent) of the 89 water samples were soft (less than $60 \mathrm{mg} / \mathrm{L}$ as $\mathrm{CaCO}_{3}$ ), 48 samples (54 percent) were moderately hard (61 to $120 \mathrm{mg} / \mathrm{L}$ as $\mathrm{CaCO}_{3}$ ), and 6 samples (7 percent) were hard (121 to $180 \mathrm{mg} / \mathrm{L}$ as $\mathrm{CaCO}_{3}$ ) (table 11 at back of report). Hardness varied with $\mathrm{pH}$; hardness generally was greatest at intermediate $\mathrm{pH}$ values (6.5 to 7.8$)$ (fig. 9A). Water samples with low $\mathrm{pH}$ (less than 6.5) and high $\mathrm{pH}$ (greater than 7.8) typically had hardness less than $60 \mathrm{mg} / \mathrm{L}$ 
Table 3. Minimum, median, and maximum of chemical and physical properties measured in the field, and concentrations of total dissolved solids, major ions, nutrients, and bacteria determined in the laboratory for water samples collected from 89 wells in Wayne County, Pennsylvania, July-September 2014.

$\left[\mu \mathrm{S} / \mathrm{cm}\right.$, microsiemens per centimeter at 25 degrees Celsius; $\mathrm{mg} / \mathrm{L}$ as $\mathrm{CaCO}_{3}$, milligrams per liter as calcium carbonate; $\mathrm{mg} / \mathrm{L}$, milligrams per liter; ${ }^{\circ} \mathrm{C}$, degrees Celsius; $\mathrm{SiO}_{2}$, silica; $\mathrm{mg} / \mathrm{L}$ as N, milligrams per liter as nitrogen; $\mathrm{mg} / \mathrm{L}$ as $\mathrm{P}$, milligrams per liter as phosphorous; col/100 mL, colonies per $100 \mathrm{milliliters;} \mathrm{--,} \mathrm{no}$ data or not applicable; <, less than; > greater than; MCL, maximum contaminant level; HA, Health Advisory; SMCL, secondary maximum contaminant level]

\begin{tabular}{|c|c|c|c|c|c|c|c|c|c|}
\hline \multirow{2}{*}{$\begin{array}{c}\text { Well characteristics, } \\
\text { sample properties, } \\
\text { and } \\
\text { constituents }\end{array}$} & \multirow{2}{*}{ Units } & \multirow{2}{*}{$\begin{array}{c}\text { Number } \\
\text { (percent) } \\
\text { above reporting } \\
\text { level }\end{array}$} & \multicolumn{3}{|c|}{ Concentration range and median } & \multirow{2}{*}{$\begin{array}{l}\text { Number } \\
\text { (percent) } \\
\text { exceeding } \\
\text { standard }\end{array}$} & \multicolumn{3}{|c|}{$\begin{array}{l}\text { Drinking-water } \\
\text { standard }^{1}\end{array}$} \\
\hline & & & Minimum & Median & Maximum & & MCL & HA & SMCL \\
\hline \multicolumn{10}{|c|}{ Well characteristics } \\
\hline Well depth & feet & "85 & 85 & 291 & 1,300 & -- & -- & -- & -- \\
\hline Casing length & feet & ${ }^{* *} 69$ & 14 & 55 & 223 & -- & -- & -- & -- \\
\hline \multicolumn{10}{|c|}{ Field properties } \\
\hline Water temperature & ${ }^{\circ} \mathrm{C}$ & $89(100)$ & 9.5 & 10.9 & 18.2 & -- & -- & -- & -- \\
\hline Dissolved oxygen & $\mathrm{mg} / \mathrm{L}$ & $89(100)$ & 0.1 & 3.2 & 10.7 & -- & -- & -- & -- \\
\hline Specific conductance, field & $\mu \mathrm{S} / \mathrm{cm}$ & $89(100)$ & 28 & 192 & 678 & -- & -- & -- & -- \\
\hline $\mathrm{pH}$, field & $\mathrm{pH}$ units & $89(100)$ & 5.4 & 7.3 & 9.3 & a27 (30) & $6.5-8.5$ & -- & -- \\
\hline Alkalinity (dissolved) & $\mathrm{mg} / \mathrm{L}$ as $\mathrm{CaCO}_{3}$ & ${ }^{* * *} 85(100)$ & 10 & 84 & 202 & -- & -- & -- & -- \\
\hline \multicolumn{10}{|c|}{ Laboratory analyses ${ }^{2,3}$} \\
\hline Total dissolved solids & $\mathrm{mg} / \mathrm{L}$ & $89(100)$ & 24 & 120 & 370 & $0(0)$ & \multirow[t]{2}{*}{--} & \multirow[t]{2}{*}{--} & \multirow[t]{2}{*}{${ }^{\mathrm{b}} 500$} \\
\hline Total solids & $\mathrm{mg} / \mathrm{L}$ & $89(100)$ & 32 & 127.5 & 363 & & & & \\
\hline Hardness, total & $\mathrm{mg} / \mathrm{L}$ as $\mathrm{CaCO}_{3}$ & $89(100)$ & $<1$ & 74.5 & 170 & & -- & -- & $c_{--}$ \\
\hline \multicolumn{10}{|c|}{ Major ions (dissolved and total) } \\
\hline Calcium, dissolved & $\mathrm{mg} / \mathrm{L}$ & $89(100)$ & 0.21 & 23.7 & 62.3 & -- & \multirow[t]{2}{*}{--} & \multirow[t]{2}{*}{--} & \multirow[t]{2}{*}{--} \\
\hline Calcium, total & $\mathrm{mg} / \mathrm{L}$ & $89(100)$ & 0.20 & 23.9 & 57.7 & & & & \\
\hline Magnesium, dissolved & $\mathrm{mg} / \mathrm{L}$ & $89(100)$ & 0.02 & 2.92 & 7.86 & -- & -- & -- & -- \\
\hline Magnesium, total & $\mathrm{mg} / \mathrm{L}$ & $89(100)$ & 0.02 & 2.80 & 7.7 & -- & -- & -- & -- \\
\hline Sodium, dissolved & $\mathrm{mg} / \mathrm{L}$ & $89(100)$ & 0.53 & 6.54 & 143 & ${ }^{d} 14(16)$ & -- & 20 & $30-60$ \\
\hline Sodium, total & $\mathrm{mg} / \mathrm{L}$ & $87(98)$ & $<5$ & 6.8 & 158 & d14 (16) & -- & 20 & $30-60$ \\
\hline Potassium, dissolved & $\mathrm{mg} / \mathrm{L}$ & $89(100)$ & 0.29 & 0.89 & 2.15 & -- & -- & -- & -- \\
\hline Potassium, total & $\mathrm{mg} / \mathrm{L}$ & $89(100)$ & 0.30 & 0.90 & 2.1 & -- & -- & -- & -- \\
\hline Alkalinity (dissolved) & $\mathrm{mg} / \mathrm{L}$ as $\mathrm{CaCO}_{3}$ & $89(100)$ & 13.2 & 87.4 & 204 & -- & -- & -- & -- \\
\hline Bromide, dissolved & $\mathrm{mg} / \mathrm{L}$ & $89(100)$ & $<0.03$ & $<0.03$ & 0.966 & -- & -- & -- & -- \\
\hline Chloride, dissolved & $\mathrm{mg} / \mathrm{L}$ & $89(100)$ & 0.45 & 3.83 & 117 & $0(0)$ & -- & -- & ${ }^{\mathrm{b}} 250$ \\
\hline Chloride, total & $\mathrm{mg} / \mathrm{L}$ & $58(65)$ & $<1,<5$ & 5.7 & 110 & $0(0)$ & -- & -- & ${ }^{\mathrm{b}} 250$ \\
\hline Fluoride, dissolved & $\mathrm{mg} / \mathrm{L}$ & $89(100)$ & 0.02 & 0.06 & 0.35 & $0(0)$ & 4 & -- & 2 \\
\hline Sulfate, dissolved & $\mathrm{mg} / \mathrm{L}$ & $89(100)$ & 1.08 & 7.51 & 19.8 & $0(0)$ & -- & 500 & 250 \\
\hline Sulfate, total & $\mathrm{mg} / \mathrm{L}$ & $77(87)$ & $<1,<5$ & 9.4 & 20.0 & $0(0)$ & -- & 500 & 250 \\
\hline Silica, dissolved & $\mathrm{mg} / \mathrm{L}$ as $\mathrm{SiO}_{2}$ & $89(100)$ & 2.50 & 8.05 & 14.6 & -- & -- & -- & -- \\
\hline
\end{tabular}


Table 3. Minimum, median, and maximum of chemical and physical properties measured in the field, and concentrations of total dissolved solids, major ions, nutrients, and bacteria determined in the laboratory for water samples collected from 89 wells in Wayne County, Pennsylvania, July-September 2014.-Continued

$\left[\mu \mathrm{S} / \mathrm{cm}\right.$, microsiemens per centimeter at 25 degrees Celsius; $\mathrm{mg} / \mathrm{L}$ as $\mathrm{CaCO}_{3}$, milligrams per liter as calcium carbonate; $\mathrm{mg} / \mathrm{L}$, milligrams per liter; ${ }^{\circ} \mathrm{C}$, degrees Celsius; $\mathrm{SiO}_{2}$, silica; $\mathrm{mg} / \mathrm{L}$ as N, milligrams per liter as nitrogen; $\mathrm{mg} / \mathrm{L}$ as $\mathrm{P}$, milligrams per liter as phosphorous; col/100 mL, colonies per $100 \mathrm{milliliters;} \mathrm{--,} \mathrm{no}$ data or not applicable; <, less than; > greater than; MCL, maximum contaminant level; HA, Health Advisory; SMCL, secondary maximum contaminant level]

\begin{tabular}{|c|c|c|c|c|c|c|c|c|c|}
\hline \multirow{2}{*}{$\begin{array}{c}\text { Well characteristics, } \\
\text { sample properties, } \\
\text { and } \\
\text { constituents }\end{array}$} & \multirow{2}{*}{ Units } & \multirow{2}{*}{$\begin{array}{c}\text { Number } \\
\text { (percent) } \\
\text { above reporting } \\
\text { level }\end{array}$} & \multicolumn{3}{|c|}{ Concentration range and median } & \multirow{2}{*}{$\begin{array}{l}\text { Number } \\
\text { (percent) } \\
\text { exceeding } \\
\text { standard }\end{array}$} & \multicolumn{3}{|c|}{$\begin{array}{l}\text { Drinking-water } \\
\text { standard }{ }^{1}\end{array}$} \\
\hline & & & Minimum & Median & Maximum & & MCL & HA & SMCL \\
\hline \multicolumn{10}{|c|}{ Nutrients (dissolved or total) } \\
\hline Kjeldahl nitrogen, total & $\mathrm{mg} / \mathrm{L}$ as $\mathrm{N}$ & $5(6)$ & $<1.0$ & $<1.0$ & 2.6 & -- & -- & -- & -- \\
\hline Ammonia, dissolved & $\mathrm{mg} / \mathrm{L}$ as $\mathrm{N}$ & $12(13)$ & $<0.01$ & $<0.01$ & 0.08 & $0(0)$ & -- & 30 & -- \\
\hline Nitrate + Nitrite, dissolved ${ }^{4}$ & $\mathrm{mg} / \mathrm{L}$ as $\mathrm{N}$ & $76(85)$ & $<0.04$ & 0.42 & 4.36 & $0(0)$ & 10 & -- & -- \\
\hline Orthophosphate, dissolved & $\mathrm{mg} / \mathrm{L}$ as $\mathrm{P}$ & $84(94)$ & $<0.004$ & 0.014 & 0.061 & -- & -- & -- & -- \\
\hline \multicolumn{10}{|c|}{ Bacteria (total) } \\
\hline Total coliform & $\mathrm{col} / 100 \mathrm{~mL}$ & $22(25)$ & $<1$ & $<1$ & $>200$ & $22(25)$ & $<1$ & -- & -- \\
\hline Escherichia Coli & $\mathrm{col} / 100 \mathrm{~mL}$ & $2(2)$ & $<1$ & $<1$ & 2 & $2(2)$ & 0 & - & -- \\
\hline \multicolumn{10}{|c|}{${ }^{3}$ Laboratory analysis for total concentrations in unfiltered samples done by contract laboratories using drinking-water methods (see Appendix 2). } \\
\hline \multicolumn{10}{|c|}{${ }^{4}$ Because nitrite concentrations are low, nitrate is nearly equivalent to nitrate plus nitrite. } \\
\hline \multicolumn{10}{|c|}{${ }^{a} \mathrm{pH}$ was less than 6.5 in 20 samples ( 22 percent) and greater than 8.5 in 7 samples ( 8 percent). } \\
\hline \multicolumn{10}{|c|}{${ }^{\text {b }}$ Same standard established by Pennsylvania Department of Environmental Protection (2010) for flow-back discharge to streams. } \\
\hline \multicolumn{10}{|c|}{$\begin{array}{l}{ }^{\mathrm{c}} \text { No drinking-water standard but water characterized as: soft, } 0-60 \mathrm{mg} / \mathrm{L} \text { in } 35 \mathrm{samples}(39 \text { percent); moderately hard, } 61-120 \mathrm{mg} / \mathrm{L} \text { in } 48 \mathrm{samples} \\
\text { (54 percent); hard, } 121-180 \mathrm{mg} / \mathrm{L} \text { in } 6 \text { samples ( } 7 \text { percent); and very hard, }>180 \mathrm{mg} / \mathrm{L} \text { in } 0 \text { samples }(0 \text { percent). }\end{array}$} \\
\hline \multicolumn{10}{|c|}{ d 14 samples exceeded HA of $20 \mathrm{mg} / \mathrm{L}$ and 6 samples exceeded upper SMCL limit of $60 \mathrm{mg} / \mathrm{L}$ for sodium. } \\
\hline \multicolumn{10}{|c|}{${ }^{*}$ Data on depths available for 85 wells. } \\
\hline${ }^{* *}$ Data on casing lengths avai & le for 69 wells. & & & & & & & & \\
\hline
\end{tabular}

as $\mathrm{CaCO}_{3}$ and were soft. There are no health-related standards established specifically for hardness in drinking water.

Water-resources engineers commonly identify the corrosion and encrustation potential of water on the basis of the Langelier Index (LI), which provides an indication of the potential for lead and copper to enter water supplies from pipes and plumbing (Snoeyink and Jenkins, 1981). The LI, which is the difference between the measured $\mathrm{pH}$ and the $\mathrm{pH}$ at equilibrium with calcite $\left(\mathrm{CaCO}_{3}\right)$, is equal in value to the calcite saturation index (SICAL), discussed in more detail in section "Geochemical Modeling." If the LI or SICAL is positive, the $\mathrm{pH}$ is greater than that at equilibrium with $\mathrm{CaCO}_{3}$, and the water will tend to deposit a $\mathrm{CaCO}_{3}$ coating or scale that can insulate pipes, boilers, and other components of a system from contact with water; however, if the LI is negative, the water is undersaturated with $\mathrm{CaCO}_{3}$ and will tend to be corrosive in the distribution system. The optimum value for the LI or SICAL is close to zero, whereby the water will neither be strongly corrosive or scale forming. For the Wayne County groundwater samples, SICAL ranged from -4.7 to 0.5 , increasing with $\mathrm{pH}$ (fig. 9B). Of the water samples collected from 89 wells in 2014, 41 (46 percent) had LI values that were less than -1 , indicating potentially strongly corrosive characteristics, and these samples were acidic with $\mathrm{pH}$ less than 7 (and also soft, fig. 9A). The remaining samples are considered neither strongly corrosive nor scale forming. 


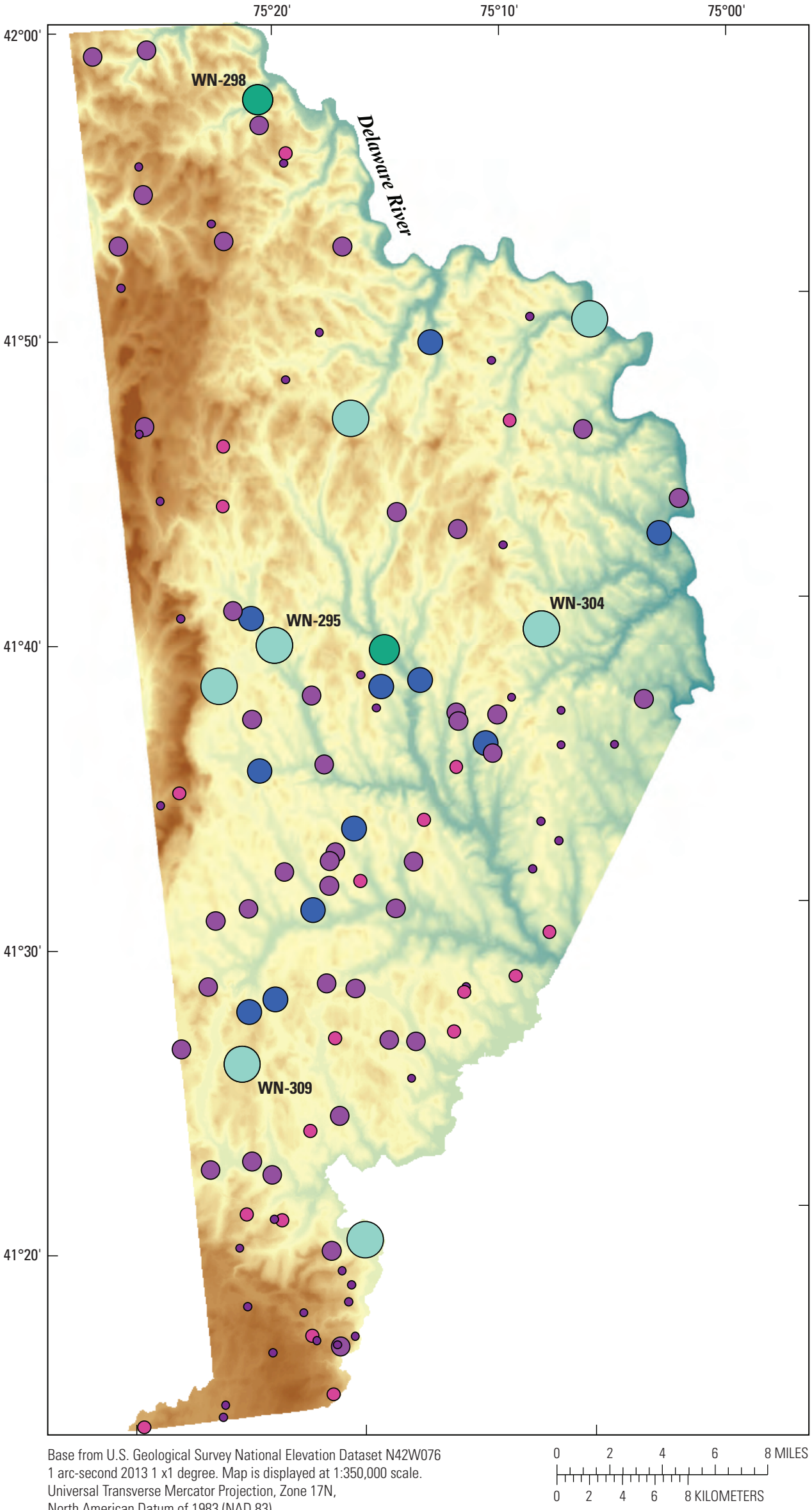

\section{EXPLANATION}

Land-surface elevation above NAVD 88

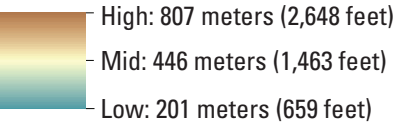

$\mathrm{pH}$ value of water sample

- 5.40 to 6.5

○ 6.51 to 7.0

7.01 to 7.5

7.51 to 8.0

8.01 to 8.5

( 8.51 to 9.3

Figure 6. Spatial distribution of $\mathrm{pH}$ in water samples collected from 89 wells in 2014 and 32 wells in 2013 in Wayne County, Pennsylvania. For four wells (WN-295, 298, 304, and 309) sampled twice, results for 2014 are plotted on top of results for 2013. 

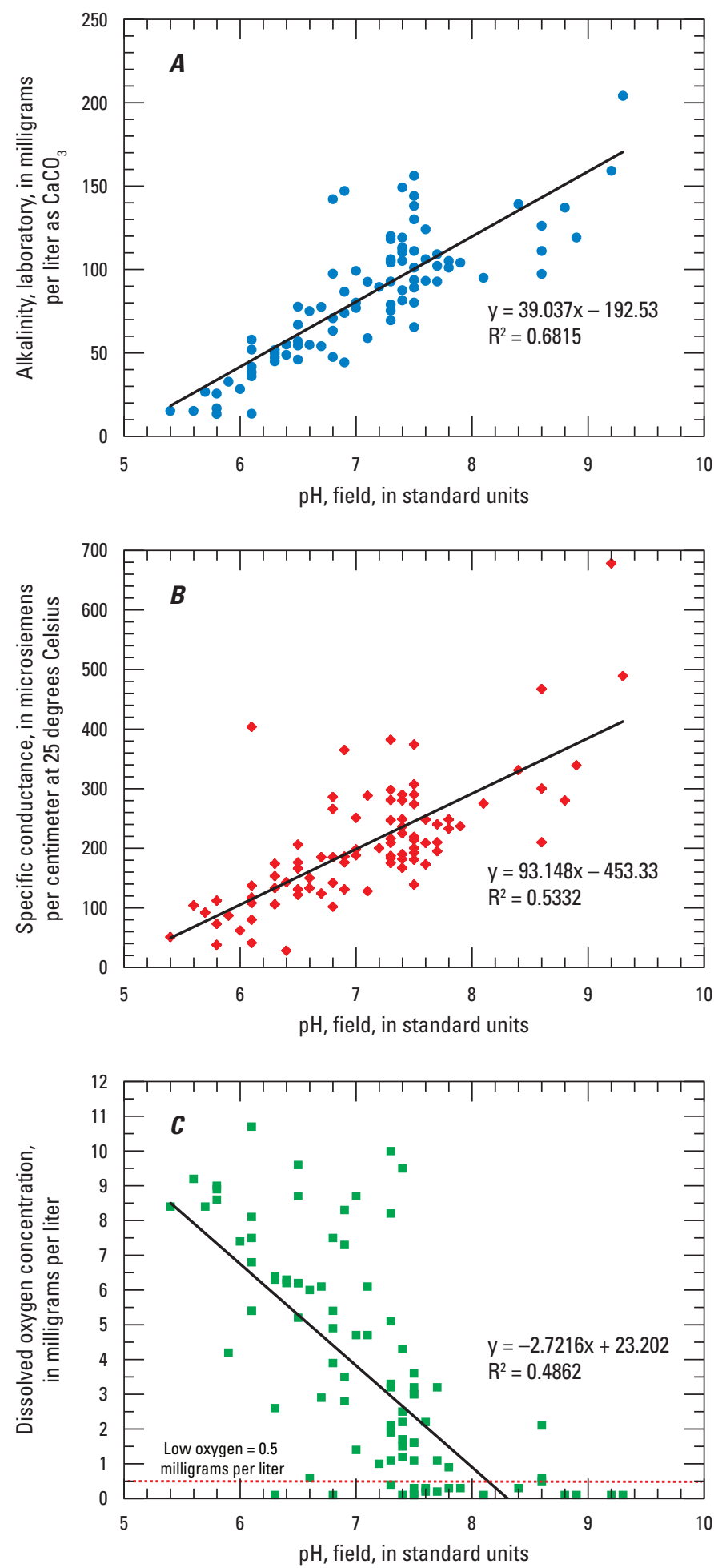

Figure 7. Relation between field measured $\mathrm{pH}$ and $A$, laboratory alkalinity, $B$, field specific conductance, and $C$, dissolved oxygen concentrations in water samples collected from 89 wells in Wayne County, Pennsylvania, July-September 2014.

\section{Major and Minor lons}

Sources of major and minor ions include atmospheric precipitation, mineral dissolution, and compounds introduced or associated with land-use practices such as use of deicing salts on roads, on-site wastewater disposal (septic systems), and agricultural application of lime or fertilizers on fields. The major ions consist of positively charged cations (calcium, magnesium, sodium, and potassium) balanced by negatively charged anions (bicarbonate, chloride, sulfate). Silica is a major constituent that commonly occurs as an uncharged ion. Nitrate, discussed in the section "Nutrients," is an anion that sometimes is present in large enough concentrations to be considered a major ion; nitrite rarely is present in concentrations greater than $1 \mathrm{mg} / \mathrm{L}$ in groundwater. Ammonia, a nitrogen compound that commonly occurs in groundwater as the cation ammonium, occasionally may be present in large enough concentrations to be considered a major ion. Drinking-water standards have been established for only a few major ions and, except for two nitrogen compounds (nitrate and nitrite), are typically either a SMCL or HA, both of which are recommended rather than required standards.

Fluoride and bromide are minor anions typically present in concentrations of less than $1 \mathrm{mg} / \mathrm{L}$ in Wayne County groundwater. Of these minor ions, only fluoride has an established MCL in drinking water.

The summary statistics for concentrations of major and minor ions listed in table 3 show that only sodium is present in concentrations greater than a HA or SMCL. Sodium concentrations were greater than the HA level of $20 \mathrm{mg} / \mathrm{L}$

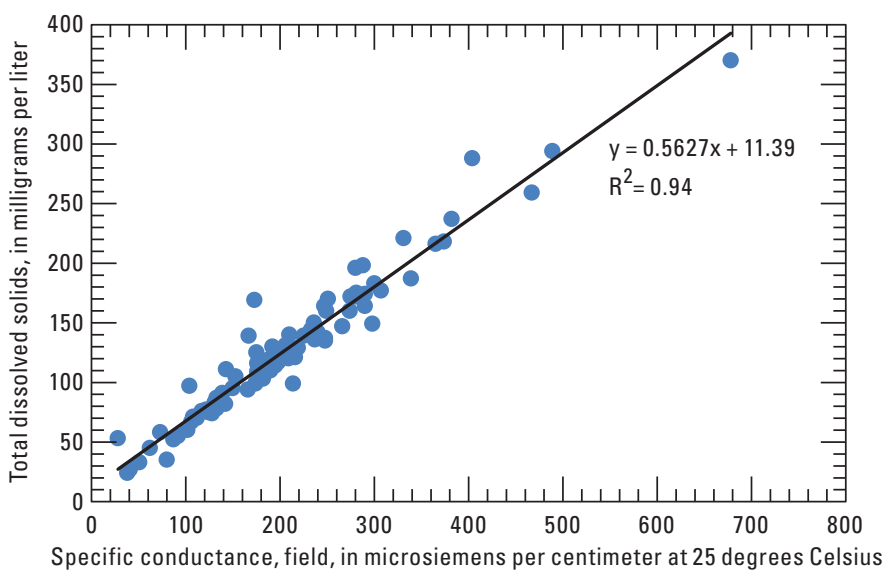

Figure 8. Relation between field measured specific conductance and concentrations of total dissolved solids in water samples collected from 89 wells in Wayne County, Pennsylvania, July-September 2014. 

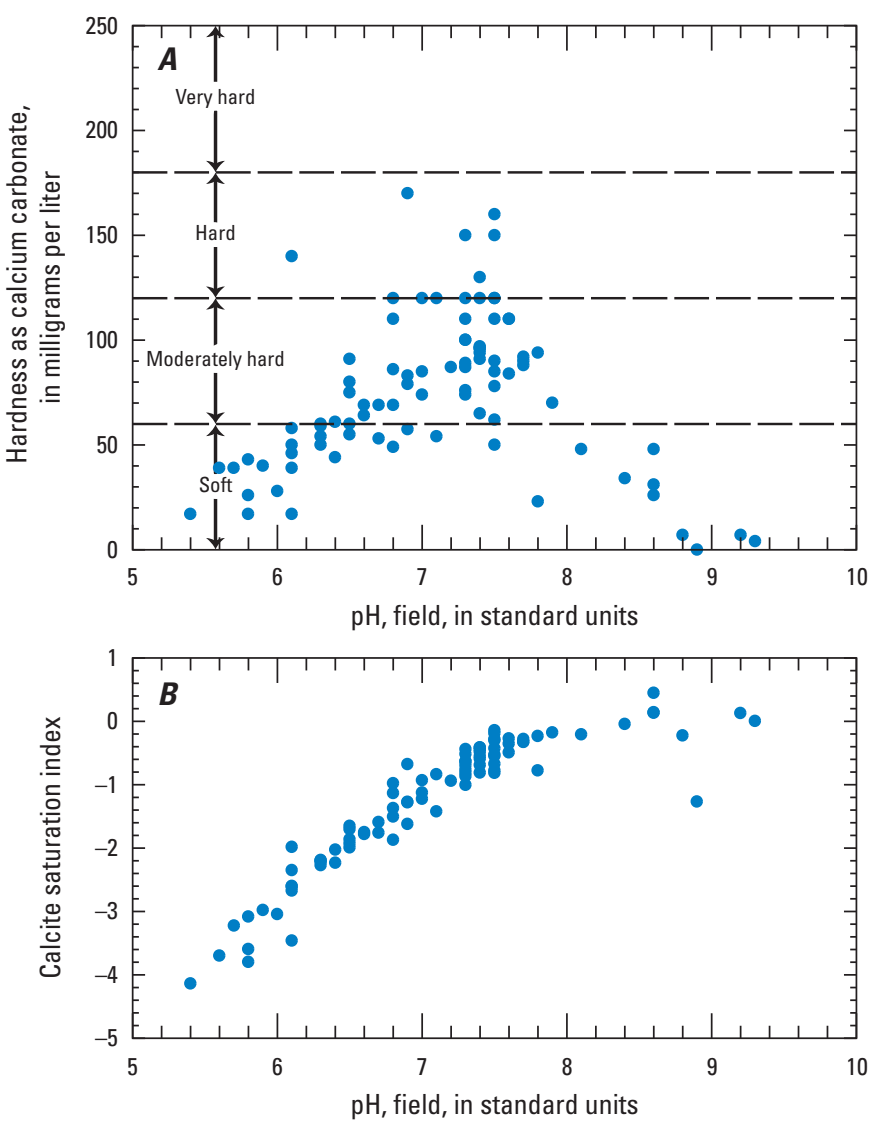

Figure 9. Relation between field measured $\mathrm{pH}$ and $A$, hardness, and $B$, corrosivity (as measured by calcite saturation index) in water samples collected from 89 wells in Wayne County, Pennsylvania, July-September 2014.

\section{Nutrients}

The nutrients nitrogen $(\mathrm{N})$ and phosphorus $(\mathrm{P})$ most commonly are present in groundwater in the dissolved phase. Sources of nitrogen include atmospheric precipitation, decomposing organic matter (leaves and other vegetation), fertilizers, animal wastes, and septic systems; the latter three sources potentially contribute greater amounts to groundwater than precipitation, depending on land use in recharge area. Nitrogen may be present in various forms, depending on origin and geochemical environment. Ammonia and nitrite tend to be present in reducing (low oxygen concentrations typically less than $0.5 \mathrm{mg} / \mathrm{L}$ ) environments, and nitrate tends to be present in oxidizing environments (oxygen concentrations typically greater than $0.5 \mathrm{mg} / \mathrm{L}$ ). Sources of phosphorus include mineral dissolution, fertilizers, and septic systems. Orthophosphate is a common soluble form of phosphorus.

Ammonia and nitrite were detected in less than 15 percent of the samples at concentrations that did not exceed respective drinking-water standards (table 3). Nitrate was detected in 85 percent of the samples at low to moderate concentrations that ranged up to about $4.4 \mathrm{mg} / \mathrm{L}$ as $\mathrm{N}$ but did not exceed the MCL of $10 \mathrm{mg} / \mathrm{L}$ as $\mathrm{N}$ in any sample. Orthophosphate was detected in 94 percent of the samples, with concentrations ranging up to $0.061 \mathrm{mg} / \mathrm{L}$ as $\mathrm{P}$ and greater than or equal to $0.02 \mathrm{mg} / \mathrm{L}$ as $\mathrm{P}$ in 29 samples (about 33 percent). Concentrations of orthophosphate greater than 0.01 to $0.02 \mathrm{mg} / \mathrm{L}$ in streams in glaciated northeastern Pennsylvania may represent slight enrichment relative to reference conditions (U.S. Environmental Protection Agency, 2001) and could be from human-related sources (Andrew Reif, U.S. Geological Survey, oral commun., 2008) or from groundwater with orthophosphate concentrations greater than $0.02 \mathrm{mg} / \mathrm{L}$ as $\mathrm{P}$ in the form of base-flow contributions (Denver and others, 2010). Sources of elevated orthophosphate in the Wayne County groundwater samples have not been identified but could include dissolution of apatite or other phosphorusbearing minerals in addition to phosphorus from wastewater disposal and fertilizers.

\section{Bacteria}

Total coliform bacteria were detected in 22 of 89

(25 percent) well-water samples (table 3), with concentrations ranging from 1 colony per 100 milliliter [reported as most probable number per 100 milliliters (MPN/100 mL)] to $38 \mathrm{MPN} / 100 \mathrm{~mL}$ in 19 samples and greater than $200 \mathrm{MPN} / 100 \mathrm{~mL}$ in 3 samples. The presence of total coliform does not necessarily indicate pathogenic bacteria but does indicate potential pathways from the surface or near surface to groundwater. Guidelines for evaluation of health risks associated with bacteria state that analysis for bacteria of fecal origin, such as E. Coli, should be done if total coliform bacteria are detected (U.S. Environmental Protection Agency, 2012). Of the 22 samples that had total coliform bacteria, only 2 samples had detectable $E$. Coli in very low concentrations 


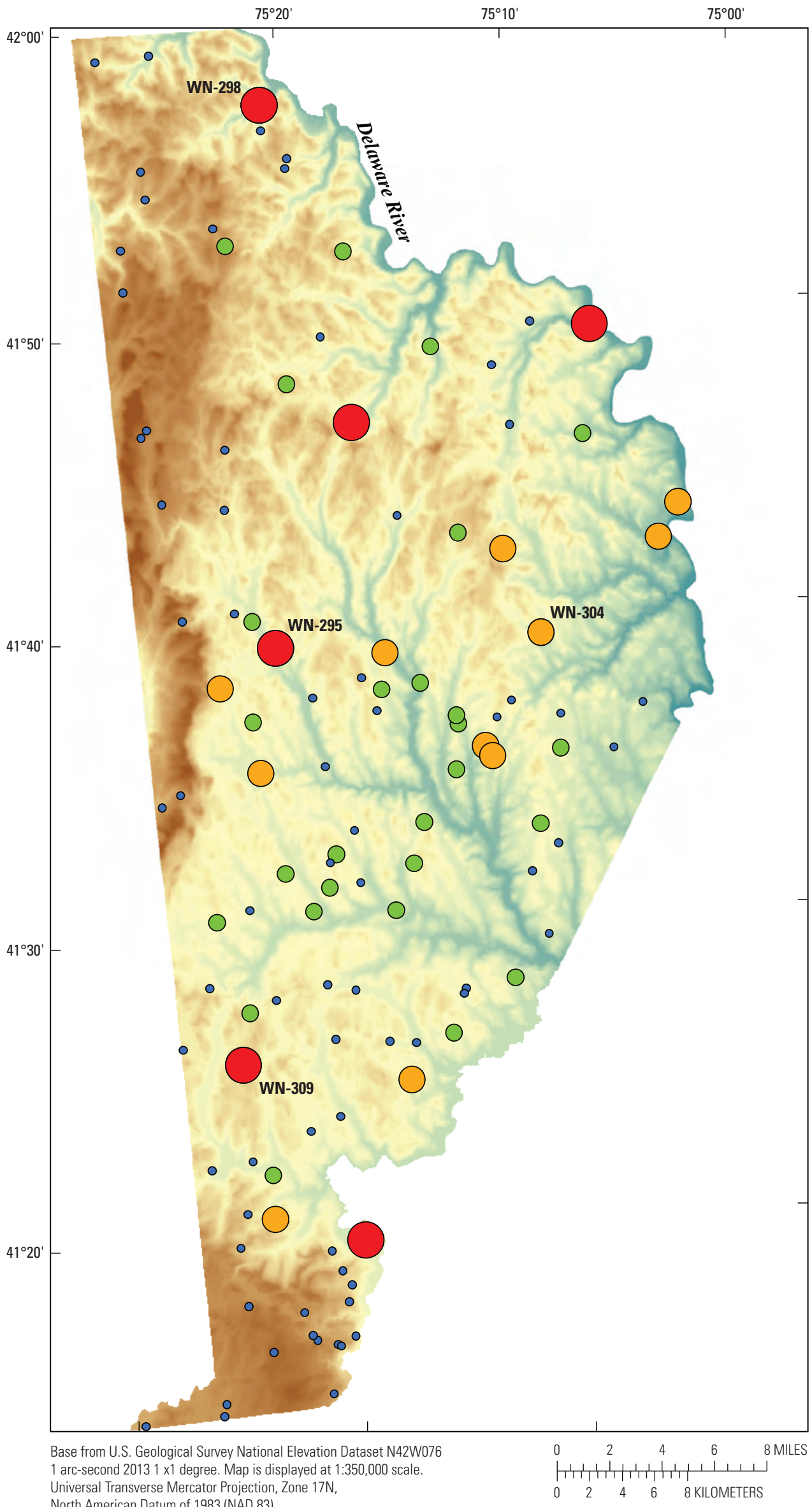

\section{EXPLANATION}

Land-surface elevation above NAVD 88

High: 807 meters (2,648 feet)

- Mid: 446 meters (1,463 feet)

Low: 201 meters (659 feet)

Sodium concentration,

in milligrams per liter

- 0 to 9.9

10.0 to 19.9

20.0 to 59.9

60.0 to 143

Figure 10. Spatial distribution of dissolved sodium concentrations in water samples collected from 89 wells in 2014 and 32 wells in 2013 in Wayne County, Pennsylvania. For four wells (WN-295, 298, 304, and 309) sampled twice, results for 2014 are plotted on top of results for 2013. 
of 1 and 2 MPN/100 mL. Low bacteria concentrations near or at detection levels are uncertain, and the replicate sample for one of these two samples had no E.Coli present (Appendix 3). Possible sources of $E$. Coli include on-site wastewater disposal (septic system, sand mound) or other infiltration of surface waters containing fecal matter.

\section{Trace Elements and Metals}

Most analyses for inorganic trace constituents (metals and other elements) were conducted on filtered samples (table 4) and represent dissolved concentrations. Analyses for a few constituents - barium, iron, manganese, and strontiumwere conducted on both filtered and unfiltered samples (table 4), using drinking-water methods on unfiltered samples and USGS methods on filtered samples for these constituents. Little to no differences between dissolved and total concentrations of barium and strontium were apparent, indicating these constituents are present in the dissolved form in the groundwater samples. Differences between dissolved and total concentrations of manganese generally were small, also indicating manganese generally occurs in the dissolved form. Substantial differences in dissolved and total concentrations of iron were measured for some samples, with total concentrations exceeding dissolved concentrations by more than $100 \mu \mathrm{g} / \mathrm{L}$ and up to about $8,750 \mu \mathrm{g} / \mathrm{L}$ in 12 of 89 samples (13 percent). Differences in dissolved and total concentrations of trace constituents may occur, sometimes caused by presence of, or adsorption of, trace metals on particulate iron or manganese oxides. Consequently, concentrations of some constituents (such as arsenic), in some cases, may exceed respective MCLs or SMCLs in unfiltered samples but not in filtered samples.

Of the 20 inorganic trace constituents (metals and other elements) included in 2014 analyses of filtered water samples, 19 were present in concentrations greater than the reporting level in at least one sample (table 4). Dissolved concentrations of the most frequently detected inorganic trace constituents (strontium, barium, lithium) generally were higher than dissolved concentrations of the less frequently detected constituents. Barium, strontium, and lithium dissolved concentrations were measured at values greater than the reporting levels in all 89 samples. Arsenic, copper, and lead were the next most frequently detected metals. Boron concentrations tended to be higher than the concentrations of lithium and three other metals (arsenic, copper, and lead), but boron was detected less frequently because its reporting level of $5 \mu \mathrm{g} / \mathrm{L}$ was relatively high.

\section{Arsenic}

Of the trace constituents analyzed, only arsenic exceeded a primary drinking-water standard. Dissolved arsenic concentrations exceeded the MCL of $10 \mu \mathrm{g} / \mathrm{L}$ in 4 of 89 samples (4.5 percent) and were higher than the HA level of $2 \mu \mathrm{g} / \mathrm{L}$ in 27 of 89 samples (30 percent). Elevated arsenic concentrations generally occur in water with elevated $\mathrm{pH}$. Arsenic concentrations in groundwater samples collected in Wayne County in 2014 (fig. 11A) and 2013 (Sloto, 2014) generally were higher than the MCL of $10 \mu \mathrm{g} / \mathrm{L}$ only when the $\mathrm{pH}$ was greater than 7.8 and higher than the HA of $2 \mu \mathrm{g} / \mathrm{L}$ when the $\mathrm{pH}$ was greater than 7.2. The relation between elevated $\mathrm{pH}$ and elevated arsenic concentrations in Wayne County may be attributed to the increased mobility of arsenic under these geochemical conditions. The spatial distribution of dissolved arsenic concentrations in Wayne County groundwater in 2013 and 2014 is shown in figure 12. Although the dissolved arsenic concentrations in water from four wells sampled in both years were similar, the arsenic concentration in one well (WN-304) exceeded the MCL of $10 \mu \mathrm{g} / \mathrm{L}$ in $2013(20.9 \mu \mathrm{g} / \mathrm{L})$ but was slightly less than the MCL in $2014(9.5 \mu \mathrm{g} / \mathrm{L})$

(see Appendix 3).

Increases in $\mathrm{pH}$ to levels greater than 7 may result in mobilization of some negatively charged ions (anions) that tend to be adsorbed on iron oxides or other mineral surfaces in aquifer materials at low pH (see fig. 27A in "Geochemical Modeling" section). Arsenic commonly is present in groundwater as arsenate $\left(\mathrm{AsO}_{4}{ }^{3-}\right)$ or, in more reducing conditions, arsenite $\left(\mathrm{AsO}_{3}{ }^{3-}\right)$, both oxyanions (Welch and others, 2000). Under acidic conditions or at $\mathrm{pH}$ less than 8 , arsenate tends to remain mostly sorbed on aquifer materials, but at $\mathrm{pH}$ greater than 8 , arsenate can be mobilized (desorbed) to a greater extent. Using a geochemical model to evaluate ion sorption on iron oxides (that commonly are present in aquifer materials), the simulated fraction of arsenic (as arsenate) in solution exceeds 35 percent at $\mathrm{pH}$ values greater than 8 (see fig. 27A in "Geochemical Modeling” section).

Other constituents that have some chemical characteristics similar to arsenic, forming oxyanions that are more mobile at higher $\mathrm{pH}$ values, include molybdenum, antimony, and selenium. Of these metals in the Wayne County groundwater samples, the relation between increasing $\mathrm{pH}$ and dissolved concentrations was strongest for molybdenum (Appendix 4, fig. A4-1); the highest molybdenum concentrations were measured in samples with $\mathrm{pH}$ greater than 7.5 (fig. 11B), a value above which geochemical modeling indicates greater than 90 percent of the molybdenum ion molybdenate $\left(\mathrm{MoO}_{4}{ }^{2-}\right)$ is likely to be dissolved rather than adsorbed (see fig. 27A in "Geochemical Modeling” section).

\section{Iron and Manganese}

Total iron concentrations were greater than the SMCL of $300 \mu \mathrm{g} / \mathrm{L}$ in 9 of 89 samples (10 percent), but dissolved iron concentrations did not exceed this standard, indicating that the particulate phase of iron can be a water-quality concern. Concentrations of dissolved and total manganese were similar, and concentrations of both exceeded the SMCL of $50 \mu \mathrm{g} / \mathrm{L}$ in 2 of 89 samples ( 2.2 percent), indicating that the dissolved phase of manganese is predominant and can be a water-quality concern. No sample had dissolved or total manganese concentrations that exceeded the HA of $300 \mu \mathrm{g} / \mathrm{L}$. 
Table 4. Minimum, median, and maximum concentrations of trace elements and metals determined in the laboratory for water samples collected from 89 wells in Wayne County, Pennsylvania, July-September 2014.

$[\mu \mathrm{g} / \mathrm{L}$, micrograms per liter; <, less than; --, no data or not applicable; MCL, maximum contaminant level; HA, Health Advisory; SMCL, secondary maximum level]

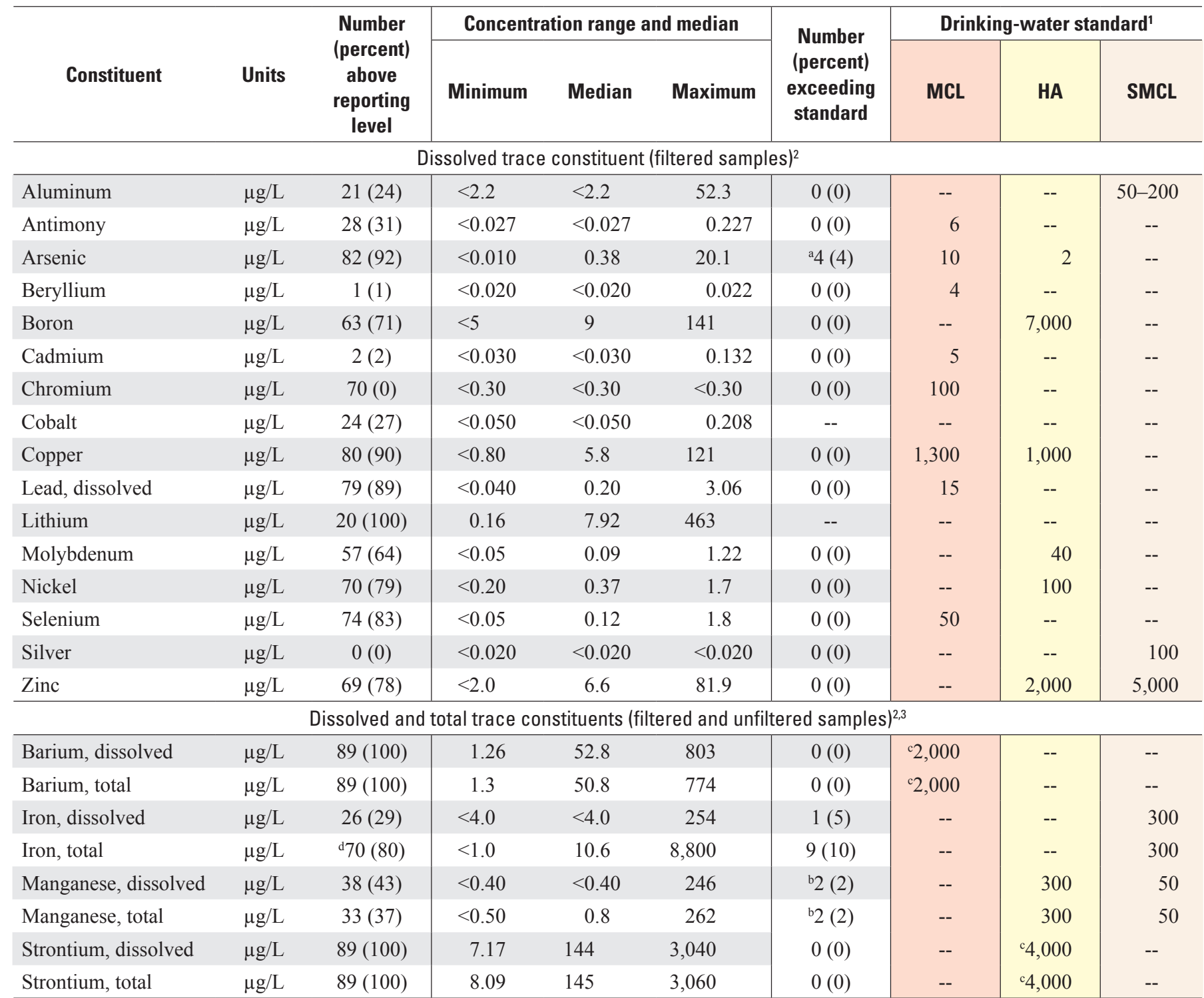

${ }^{1}$ U.S. Environmental Protection Agency (2012).

${ }^{2}$ Laboratory analysis for dissolved concentrations in filtered samples done by U.S. Geological Survey National Water Quality Laboratory (NWQL).

${ }^{3}$ Laboratory analysis for total concentrations in unfiltered samples done by contract laboratories using drinking-water methods (see Appendix 2).

${ }^{a}$ Four samples exceed the MCL of $10 \mu \mathrm{g} / \mathrm{L}$ and 27 samples (30 percent) exceed the HA of $2 \mu \mathrm{g} / \mathrm{L}$ for arsenic.

${ }^{\mathrm{b}}$ Two samples exceed the SMCL level of $50 \mu \mathrm{g} / \mathrm{L}$ but no (0) samples exceed the HA of $300 \mu \mathrm{g} / \mathrm{L}$ for manganese.

${ }^{c}$ Pennsylvania Department of Environmental Protection (2010) established standards are $10 \mathrm{mg} / \mathrm{L}(10,000 \mu \mathrm{g} / \mathrm{L})$ for barium and $10 \mathrm{mg} / \mathrm{L}(10,000 \mu \mathrm{g} / \mathrm{L})$ for strontium in flow-back discharge to streams.

${ }^{\mathrm{d}}$ Missing total iron value for one sample. 

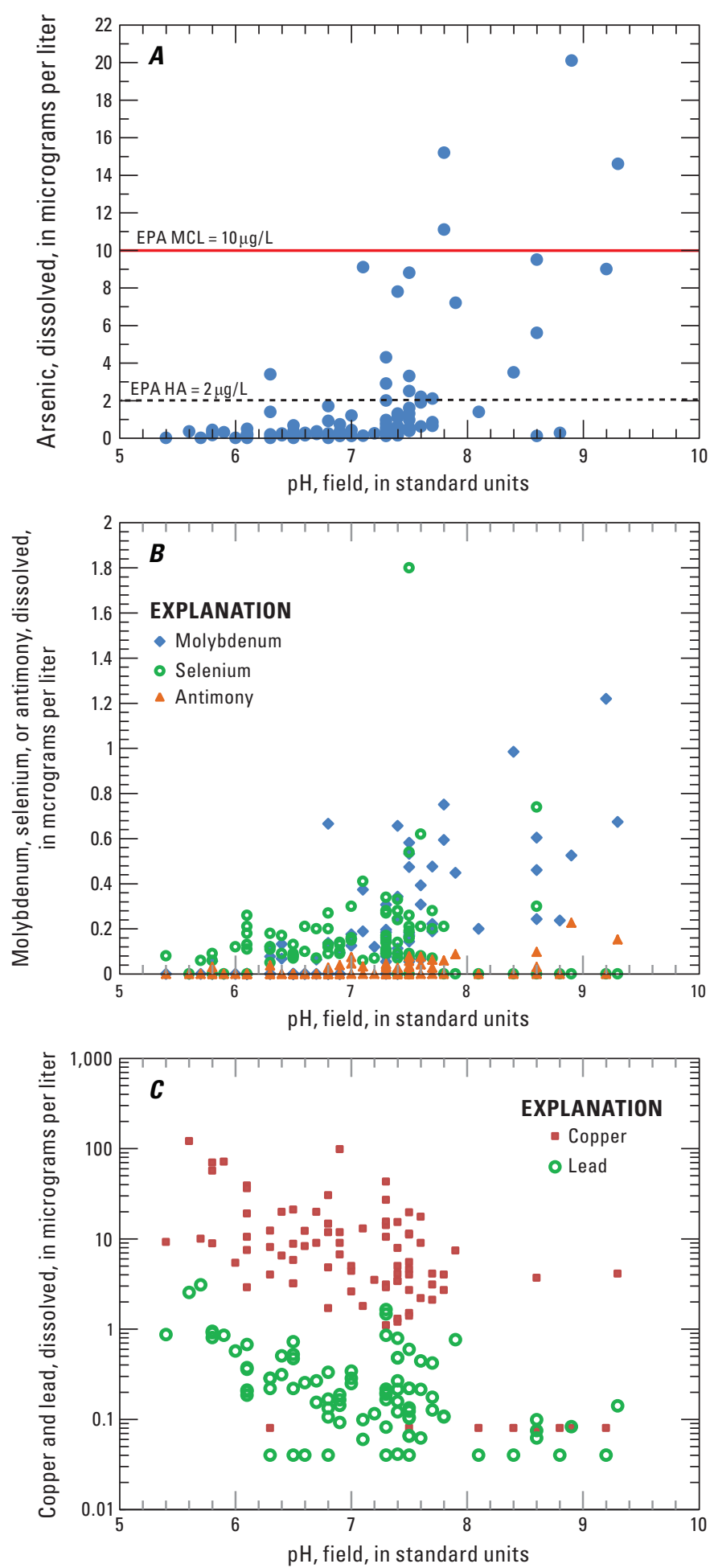

Figure 11. Relation between field measured $\mathrm{pH}$ and dissolved concentrations of $A$, arsenic, $B$, molybdenum, antimony, and selenium, and $C$, copper and lead in water samples collected from 89 wells in Wayne County, Pennsylvania, July-September 2014.
The characteristic brownish-red color of the "red beds" of the Catskill Formation result from the presence of various iron-oxide minerals, such as hematite $\left(\mathrm{Fe}_{2} \mathrm{O}_{3}\right)$ (Friend, 1966). Limonite, a family of hydrous iron oxide minerals $\left(\mathrm{FeO}(\mathrm{OH}) \cdot \mathrm{nH}_{2} \mathrm{O}\right)$ is reported to occur in the Catskill Formation in Pike County (Sevon and others, 1989). Under reducing conditions for iron and manganese oxides [Fe(III) and $\mathrm{Mn}(\mathrm{III}, \mathrm{IV})]$, the concentrations of dissolved iron and manganese and associated sorbed trace anions and cations may become elevated. The reductive dissolution of iron and manganese oxides is typically coupled with the oxidation of organic compounds after supplies of DO, nitrate $\left(\mathrm{NO}_{3}^{-}\right)$, and nitrite $\left(\mathrm{NO}_{2}^{-}\right)$have been depleted but before the development of sulfate-reducing conditions (Ehrlich, 1990; Stumm and Morgan, 1996; Drever, 1997; McMahon and Chapelle, 2008). Thus, the presence of dissolved iron, manganese, and sulfate in anoxic groundwater that lacks nitrate and nitrite can be interpreted to indicate reducing geochemical conditions capable of mobilizing trace elements associated with iron and manganese oxides in the aquifer but incapable of precipitating sulfide minerals (McMahon and Chapelle, 2008).

Dissolved iron and manganese concentrations are greater than the SMCLs of 300 and $50 \mu \mathrm{g} / \mathrm{L}$, respectively, in only a few groundwater samples in Wayne County (fig. 13, table 4), and these elevated concentrations of dissolved iron and manganese may be present where sufficient organic carbon (from natural or man-made sources) is available for oxidation. DO and nitrate concentrations are very low (less than $0.5 \mathrm{mg} / \mathrm{L}$ ), and sulfate concentrations relatively low but detectable (less than $10 \mathrm{mg} / \mathrm{L}$ ), for most of the samples with elevated iron and manganese concentrations (fig. 13), indicating reducing (but not extremely reducing) conditions potentially capable of mobilizing those trace elements that tend to sorb on iron and manganese oxides under certain $\mathrm{pH}$ conditions. However, the groundwater-quality data for Wayne County do not appear to indicate extensive mobilization of trace metals through reduction dissolution of iron oxides. Elevated concentrations of dissolved trace metals were not associated with elevated dissolved iron and manganese concentrations, perhaps because the relatively high $\mathrm{pH}$ values in these moderately reducing waters limit some trace metal mobility. The highest concentrations of copper and lead were in water samples that had among the lowest $\mathrm{pH}$ values (most acidic) (fig. 11C) in addition to relatively high concentrations of DO. These metals form cations that tend to be desorbed and mobile under acidic conditions (fig. 27B). Such metals could be mobilized from plumbing at low $\mathrm{pH}$ but also could be naturally occurring in the aquifer.

Iron occurs in particulate form to a greater extent than does manganese in the Wayne Couny groundwater samples, where the particulate concentration is the concentration of total minus dissolved metal. Total and particulate iron concentrations showed no clear relation to DO concentrations (fig. 14A), indicating that controls on the formation of particulate iron are more complex than redox conditions. Although a range of total iron concentrations was observed over the range of $\mathrm{pH}$ values for the Wayne County groundwater samples, the 


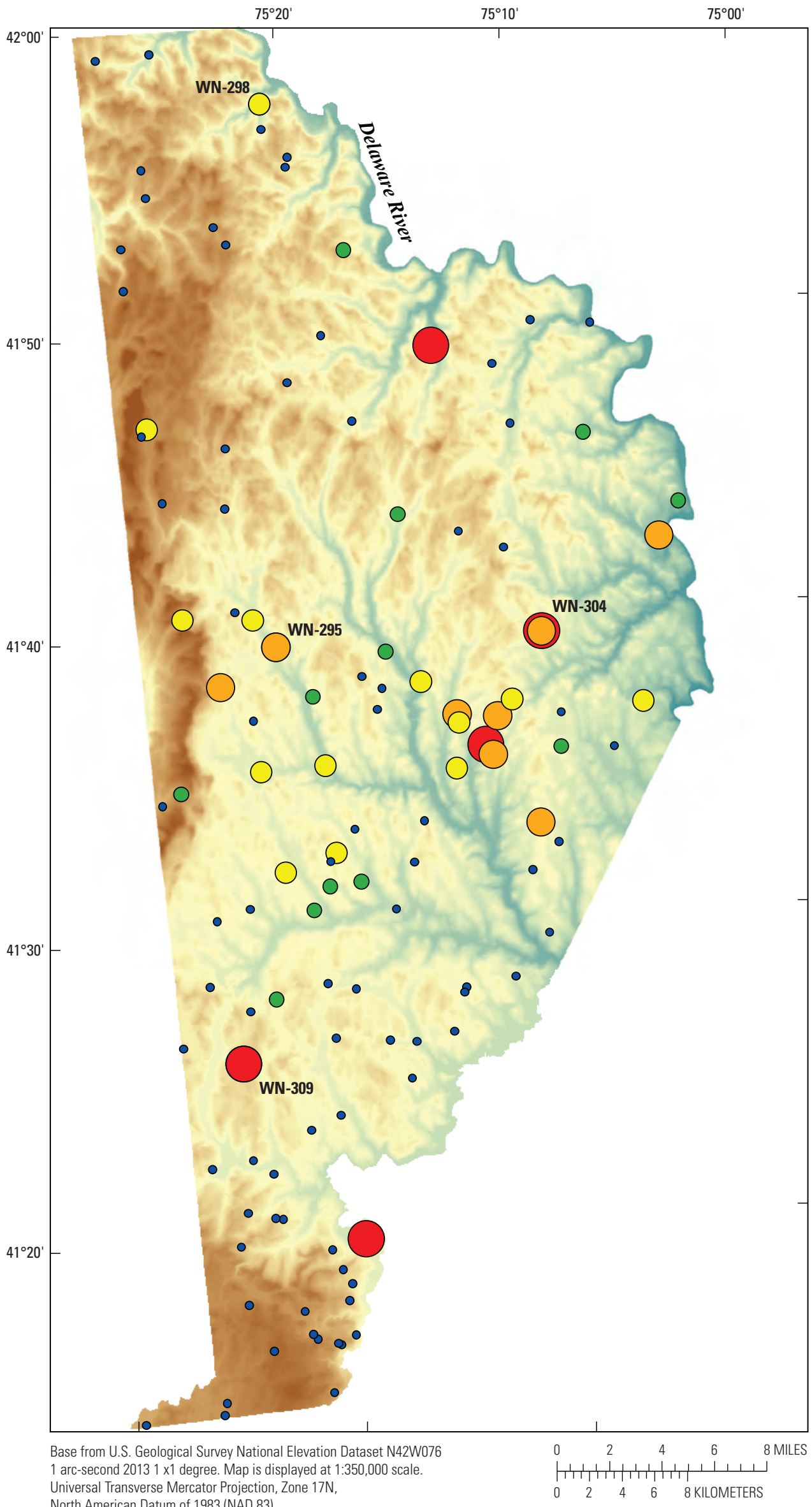

\section{EXPLANATION}

Land-surface elevation above NAVD 88

- High: 807 meters (2,648 feet)

- Mid: 446 meters (1,463 feet)

Low: 201 meters (659 feet)

Arsenic concentration,

in micrograms per liter

- 0 to 1.0

- 1.1 to 1.9

2.0 to 4.9

○ 5.0 to 9.9

10.0 to 21.8

Figure 12. Spatial distribution of dissolved arsenic concentrations in water samples collected from 89 wells in 2014 and 32 wells in 2013 in Wayne County, Pennsylvania. For four wells (WN-295, 298, 304, and 309) sampled twice, results for 2014 are plotted on top of results for 2013. 

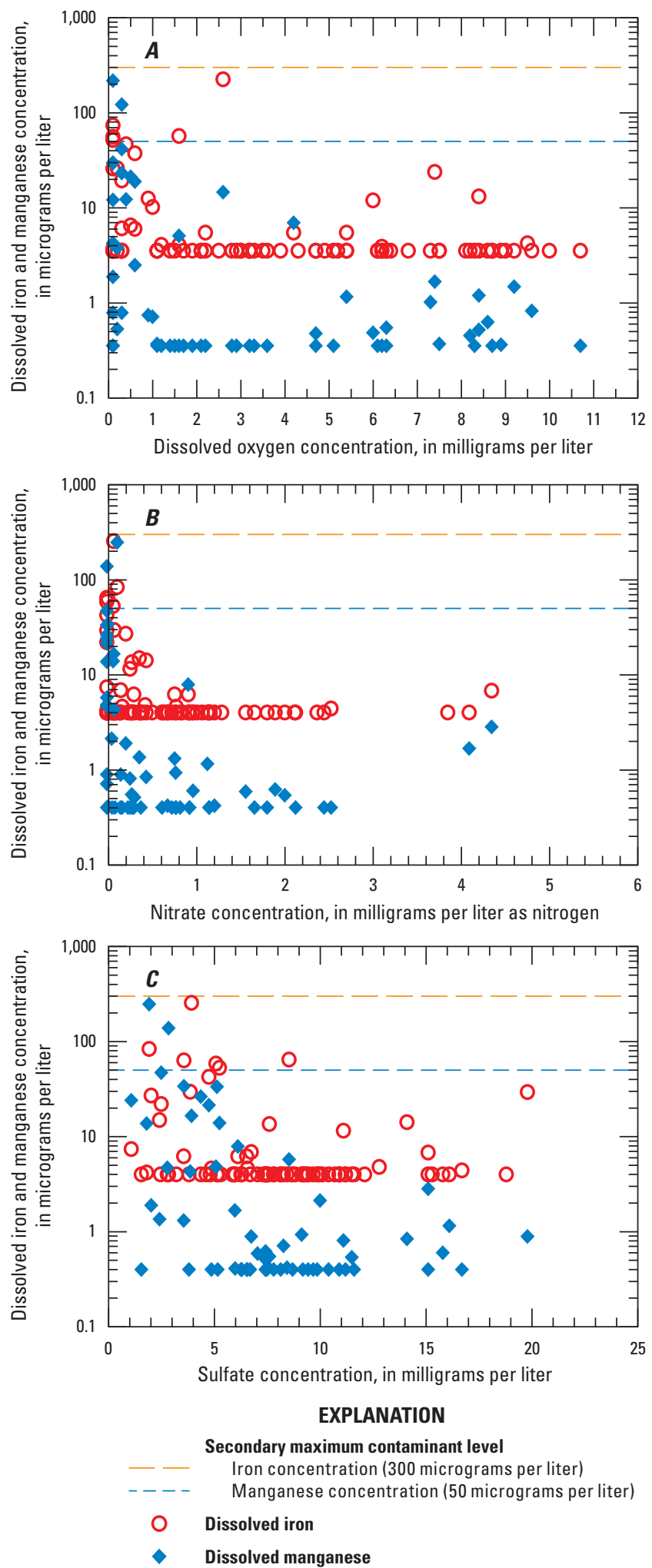

Figure 13. Concentrations of dissolved iron and manganese in relation to concentrations of $A$, dissolved oxygen, $B$, nitrate, and $C$, sulfate in water samples collected from 89 wells in Wayne County, Pennsylvania, July-September 2014. (SMCL, secondary maximum contaminant level; $\mu \mathrm{g} / \mathrm{L}$, micrograms per liter.) highest total (and particulate) iron concentrations, including all those greater than the SMCL $300 \mu \mathrm{g} / \mathrm{L}$, were in water samples having $\mathrm{pH}$ less than 7.5 (fig. 14B). Like iron, particulate manganese concentrations showed no strong relation to $\mathrm{pH}$ or $\mathrm{DO}$ concentration, but total manganese concentrations were highest at lowest DO concentrations, reflecting the predominant presence of manganese in the dissolved phase.

\section{Radionuclides}

Radionuclides naturally present in rocks and soils may enter or leach into groundwater through mineral dissolution, desorption from mineral surfaces, or in the case of radon (gas), diffusion. Naturally occurring radioactivity in groundwater is produced primarily by the radioactive decay of uranium-238 and thorium-232. These isotopes of uranium and thorium disintegrate in steps emitting either alpha or beta particles and forming a series of radioactive nuclide "daughter" products, mostly short lived, until a stable lead isotope is produced. The uranium-238 decay series commonly produces the greatest amount of radioactivity in natural groundwater (Hem, 1985, p. 147). Uranium-238 has a half-life of $4.5 \times 10^{9}$ years. Its daughter products include radium-226 (half-life of 1,620 years) and radon-222 (half-life of 3.8 days). Radon-222, a decay product of radium-226, is a colorless, odorless, chemically inert, alpha-particle-emitting gas that is soluble in water. The end product of the uranium-238 decay series is the stable isotope lead-206. Radioactivity is the release of energy and energetic particles (alpha or beta) by changes in the structure of certain unstable elements as they break down to form more stable arrangements, for which (1) alpha radiation consists of positively charged helium nuclei, (2) beta radiation consists of electrons or positrons, and (3) gamma radiation consists of electromagnetic waves.

Analyses for radioactivity and radionuclides in the 89 well-water samples collected in Wayne County in 2014 included gross alpha radioactivity, gross beta radioactivity, and dissolved radon-222 (radon gas). Uranium, a radioactive element, also was analyzed in the dissolved form. Summary statistics for radioactive constituents are given in table 5, and analytical results are provided in table 11 (back of report). Water samples were not analyzed for radium-226, a constituent that may be elevated in brines and that has an EPA (2012) $\mathrm{MCL}$ of $5 \mathrm{pCi} / \mathrm{L}$ in drinking water. Limited results for radium in groundwater in neighboring Pike County show radium-226 values were less than $1 \mathrm{pCi} / \mathrm{L}$ (Senior, 2014).

\section{Gross alpha- and gross beta-particle radioactivity}

Various radioactive isotopes present in groundwater may contribute to the total or gross radioactivity measured in a sample, as measured in analyses for gross alpha-particle and gross beta-particle radioactivity. Differences between gross alpha and gross beta radioactivity measured soon after sample collection (within 72 hours) and after 30 days indicate whether short-lived radionuclides (such as radium-224, half-life of 

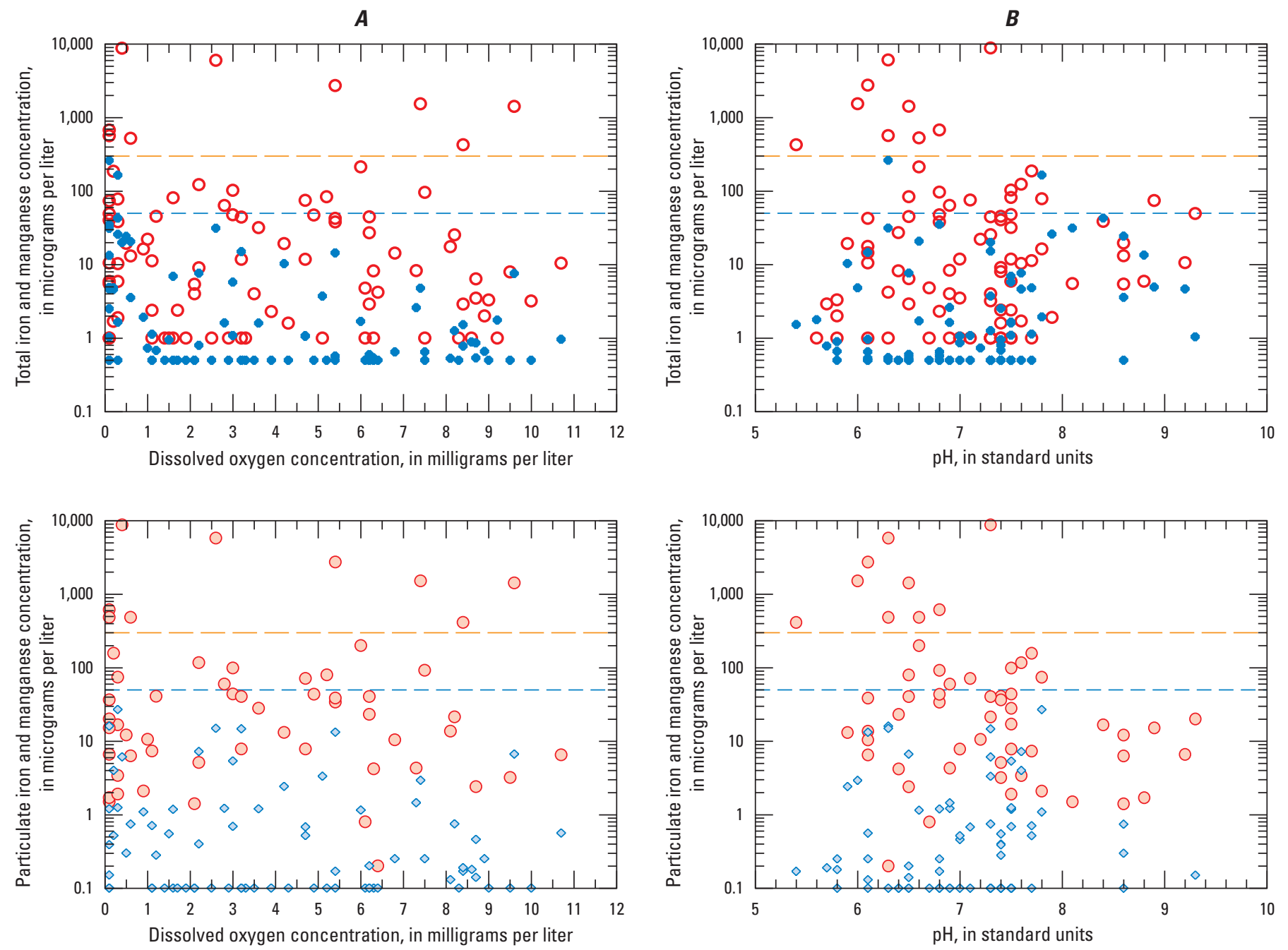

\section{EXPLANATION}

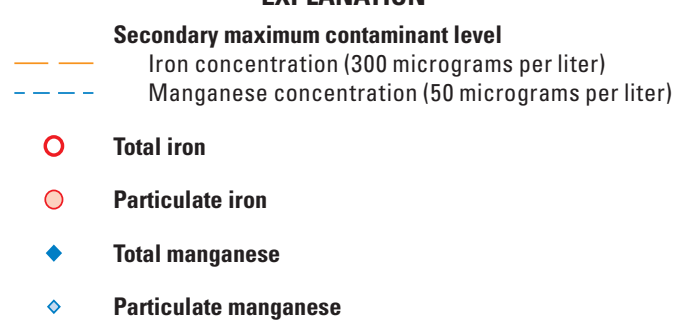

Figure 14. Concentrations of total and particulate iron and manganese in relation to concentrations of $A$, dissolved oxygen and $B, \mathrm{pH}$, in water samples collected from 89 wells in Wayne County, Pennsylvania, July-September 2014. (SMCL, secondary maximum contaminant level; $\mu \mathrm{g} / \mathrm{L}$, micrograms per liter). 
Table 5. Minimum, median, and maximum concentrations of selected radioactive constituents determined in the laboratory for water samples collected from 89 wells in Wayne County, Pennsylvania, July-September 2014.

$[\mathrm{pCi} / \mathrm{L}$, picocuries per liter; mrem/yr, millirem per year; $\mu \mathrm{g} / \mathrm{L}$, micrograms per liter; $<$, less than; --, no data or not applicable; MCL, maximum contaminant level; HA, Health Advisory; SMCL, secondary maximum level]

\begin{tabular}{|c|c|c|c|c|c|c|c|c|c|}
\hline \multirow[b]{2}{*}{ Radioactive constituent ${ }^{2}$} & \multirow[b]{2}{*}{ Units } & \multirow{2}{*}{$\begin{array}{l}\text { Number } \\
\text { (percent) } \\
\text { above } \\
\text { reporting } \\
\text { level }\end{array}$} & \multicolumn{3}{|c|}{ Concentration range and median } & \multirow{2}{*}{$\begin{array}{c}\text { Number } \\
\text { (percent) } \\
\text { exceeding } \\
\text { standard }\end{array}$} & \multicolumn{3}{|c|}{ Drinking-water standard ${ }^{1}$} \\
\hline & & & Minimum & Median & Maximum & & MCL & HA & SMCL \\
\hline \multicolumn{10}{|c|}{ Total (unfiltered sample) } \\
\hline $\begin{array}{l}\text { Gross alpha radioactivity, } \\
\text { 30-day recount }\end{array}$ & $\mathrm{pCi} / \mathrm{L}$ & $49(55)$ & -- & 0.8 & 9.8 & $0(0)$ & 15 & -- & -- \\
\hline $\begin{array}{l}\text { Gross beta radioactivity, } \\
\text { 30-day recount }\end{array}$ & $\mathrm{pCi} / \mathrm{L}$ & $69(78)$ & -- & 2.1 & 7.2 & $0(0)$ & a4 mrem/yr & -- & -- \\
\hline $\begin{array}{l}\text { Gross beta radioactivity, } \\
\text { 72-hour count }\end{array}$ & $\mathrm{pCi} / \mathrm{L}$ & $67(75)$ & -- & 1.8 & 5.8 & $0(0)$ & a $4 \mathrm{mrem} / \mathrm{yr}$ & -- & -- \\
\hline \multicolumn{10}{|c|}{ Dissolved (filtered sample) } \\
\hline Uranium (natural) & $\mu \mathrm{g} / \mathrm{L}$ & $83(93)$ & $<0.014$ & 0.824 & 16.4 & $0(0)$ & 30 & 20 & -- \\
\hline
\end{tabular}

3.6 days) are present in the sample. Because well owners are consuming water soon after it is pumped from a well, it is prudent to assess radioactivity measured as soon as possible (such as within 72 hours) relative to the established drinking-water standards. If gross alpha- or gross beta-particle activities are elevated, it is likely that a radionuclide (such as radium-226 for gross alpha-particle activities) that contributes to those radioactivities is also elevated. Thus, gross alpha- and gross beta-particle activities commonly are used to screen for possible presence of radionuclides in concentrations of concern.

The gross alpha radioactivity (72-hour count) in water from the 89 sampled wells ranged from non-detect (less than the detection limit) to $12.0 \mathrm{pCi} / \mathrm{L}$, and the median activity was $1.5 \mathrm{pCi} / \mathrm{L}$ (table 5). Values considered "non-detects" are listed with an "R" preceding the value (table 11). Most gross alpha radioactivity values were less than the method reporting level (MRL) of $3 \mathrm{pCi} / \mathrm{L}$ and, when reported without an " $\mathrm{R}$ " qualifier, are considered to be estimated values that have larger uncertainty than those quantified at greater than the MRL. Twenty of 89 samples (22.5 percent) had gross alpha radioactivity (72-hour count) greater than or equal to $3 \mathrm{pCi} / \mathrm{L}$. Gross alpha-particle activity in the 30-day count was similar to or slightly less than the activity in the 72-hour count (table 11). No water sample exceeded the EPA MCL of $15 \mathrm{pCi} / \mathrm{L}$ for gross alpha-particle activity (table 5).

The gross beta radioactivity (72-hour count) ranged from non-detect (less than the detection limit) to $5.8 \mathrm{pCi} / \mathrm{L}$, and the median activity was $1.8 \mathrm{pCi} / \mathrm{L}$ (table 5 ). Similar to gross alpha-particle activity, uncertainty is relatively greater for values less than the MRL of $3 \mathrm{pCi} / \mathrm{L}$. Seventeen of 89 samples (19.1 percent) had gross beta-particle activity (72-hour count) greater than or equal to $3 \mathrm{pCi} / \mathrm{L}$. Gross beta-particle activity in the 30-day count was similar to or slightly greater than the activity in the 72-hour count in most of the samples (table 11). Gross alpha- and gross beta-particle activities generally were directly related (fig 15A). 

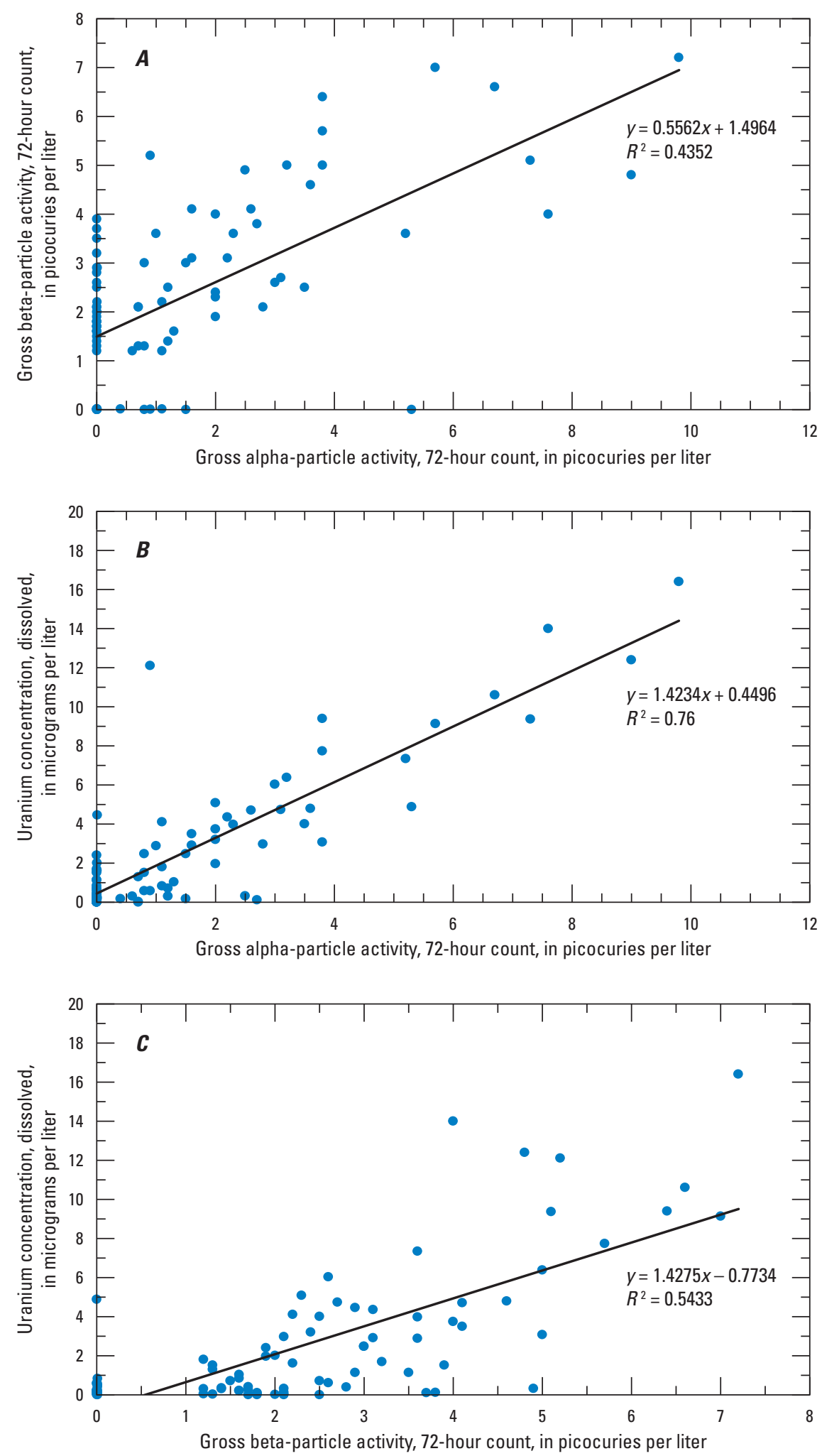

Figure 15. Relation between $A$, gross alpha-particle activity and gross beta-particle activity, $B$, gross alpha-particle activity and dissolved uranium concentrations, and $C$, gross beta-particle activity and dissolved uranium concentrations in water samples collected from 89 wells in Wayne County, Pennsylvania, July-September 2014. 


\section{Radon-222}

Radon-222, a daughter product of radium-226, is an inert gas that dissolves in water. The EPA has set health-based standards for radon-222 in air ( $4 \mathrm{pCi} / \mathrm{L})$ but currently does not regulate radon-222 in drinking water. However, under the framework specified by the 1999 Notice for the Proposed Radon in Drinking Water Rule (Federal Register, 1999), the EPA proposed an alternative maximum contaminant level (AMCL) of 4,000 pCi/L for radon-222 for community water systems that use groundwater for all or some of the supply in states with an enhanced indoor radon program. For states without an enhanced indoor air program, EPA proposed an MCL of $300 \mathrm{pCi} / \mathrm{L}$ for radon-222.

Activities of radon-222 in water from the 89 wells ranged from 25 to $7,400 \mathrm{pCi} / \mathrm{L}$, with a median activity of $2,120 \mathrm{pCi} / \mathrm{L}$ (table 5). Water samples from 86 of the 89 wells ( 97 percent) exceeded the proposed EPA MCL of $300 \mathrm{pCi} / \mathrm{L}$, and samples from 12 of the 89 wells (13 percent) exceeded the proposed EPA AMCL of 4,000 pCi/L for radon-222. Radon-222 activities in water samples from the 89 wells did not appear to be related to other measured sources of radioactivity (gross alphaor gross beta-particle radioactivity or uranium). The spatial distribution of radon-222 activities (concentrations) in Wayne County groundwater is shown in figure 16.

\section{Uranium}

The concentration of uranium ranged from less than 0.014 to $16.4 \mu \mathrm{g} / \mathrm{L}$ with a median concentration of $0.824 \mu \mathrm{g} / \mathrm{L}$ (table 5). No water samples exceeded the EPA MCL of $30 \mu \mathrm{g} / \mathrm{L}$ or the HA of $20 \mu \mathrm{g} / \mathrm{L}$ for uranium, although the highest measured uranium concentration of $16.4 \mu \mathrm{g} / \mathrm{L}$ was close to the HA. Uranium concentrations were directly related to gross alpha- and gross beta-particle activity, with a stronger relation to gross alpha-particle activity $\left(\mathrm{r}^{2}=0.76\right.$, fig. $\left.15 \mathrm{~B}\right)$ than to gross beta-particle activity $\left(\mathrm{r}^{2}=0.54\right.$, fig. 15C). Thus, gross alpha-particle activity may be more useful than gross betaparticle activity to serve as a screen for potentially elevated concentrations of uranium in Wayne County groundwater. Using the linear relation shown in figure $15 \mathrm{~B}$, estimated uranium concentrations would be predicted to exceed the HA of $20 \mu \mathrm{g} / \mathrm{L}$ at 72-hour gross alpha activities of about $14 \mathrm{pCi} / \mathrm{L}$ and the MCL of $30 \mu \mathrm{g} / \mathrm{L}$ at 72-hour gross alpha activities of about $21 \mathrm{pCi} / \mathrm{L}$.

Although measured uranium concentrations in groundwater samples did not exceed drinking-water standards, at least one sample had a concentration $(16.4 \mu \mathrm{g} / \mathrm{L})$ near the HA level of $20 \mu \mathrm{g} / \mathrm{L}$. Uranium has been reported to be present at enriched levels at some localities in the Catskill Formation in Pennsylvania (McCauley, 1961; Pirc and Rose, 1981), including central Wayne County (Kleimic, 1962); therefore, there is the potential for uranium to occur at elevated levels in groundwater at least locally in Wayne County if mobilized from aquifer materials under certain chemical conditions. Where uranium is not present in enriched concentrations in aquifer materials, elevated concentrations in groundwater are less likely. Uranium ion solubility is affected by $\mathrm{pH}$, alkalinity, and redox conditions; uranium ions can form complexes with other ions, particularly bicarbonate and carbonate, which can increase uranium mobility at neutral to alkaline $\mathrm{pH}$. The concentrations of uranium in groundwater in Wayne County tended to be highest at or near neutral $\mathrm{pH}$ (fig. 17), with low to moderate concentrations of DO (1 to $6 \mathrm{mg} / \mathrm{L})$. The spatial distribution of uranium concentrations in Wayne County groundwater is shown in figure 18.

\section{Man-made Organic Compounds}

All samples were analyzed for selected man-made (synthetic) organic compounds, including 68 VOCs, 2 glycols, 8 alcohols, and oil and grease (table 6), but none of these man-made organic compounds was measured in a detectable concentration in any sample. The reporting level for VOCs was $0.5 \mu \mathrm{g} / \mathrm{L}$, which is lower than drinking-water MCLs established for most analyzed VOCs. However, drinking-water MCLs for two compounds-1,2-dibromo-3-chloropropane (DBCP) and 1,2-dibromoethane (EDB) - are less than the method reporting level, as performed by the laboratory, so for these compounds, a more sensitive method is needed to determine whether they are present in concentrations greater than the MCLs (although below the reporting level of $0.5 \mu \mathrm{g} / \mathrm{L}$ ). Therefore, with the exception of these two compounds, if VOCs are present in groundwater at concentrations less than the reporting level of $0.5 \mu \mathrm{g} / \mathrm{L}$, those concentrations would not exceed an established drinking-water standard.

The reporting level for the analyzed glycols and alcohols was $5 \mathrm{mg} / \mathrm{L}$, a level which may not be low enough to detect the possible presence of these compounds in groundwater. However, at the time of this study, a more sensitive approved method with lower reporting levels was not available. Therefore, these analyses indicate only that glycols and alcohols were not present in concentrations greater than $5 \mathrm{mg} / \mathrm{L}$.

\section{Methane and Other Dissolved Hydrocarbon Gases}

Methane is a colorless, odorless, combustible gas that may occur naturally in groundwater. Methane may be derived from several sources, including but not limited to surficial sediments, organic-rich layers within rocks, and microbial activity involved in the breakdown of organic matter, and can be broadly classified as thermogenic or microbial (biogenic) in origin (Schoell, 1980). Thermogenic methane is formed from breakdown of organic material in sediments under high-temperature conditions caused by deep burial. In contrast, microbial methane is formed in shallow subsurface or near surface environments by microbial (bacterial) reduction of carbon dioxide or fermentation of organic debris (Breen and others, 2007). The methane present in the Marcellus Shale and Utica Shale being developed for natural gas in Pennsylvania is of thermogenic origin (Baldassare and others, 2014; Kirschbaum 


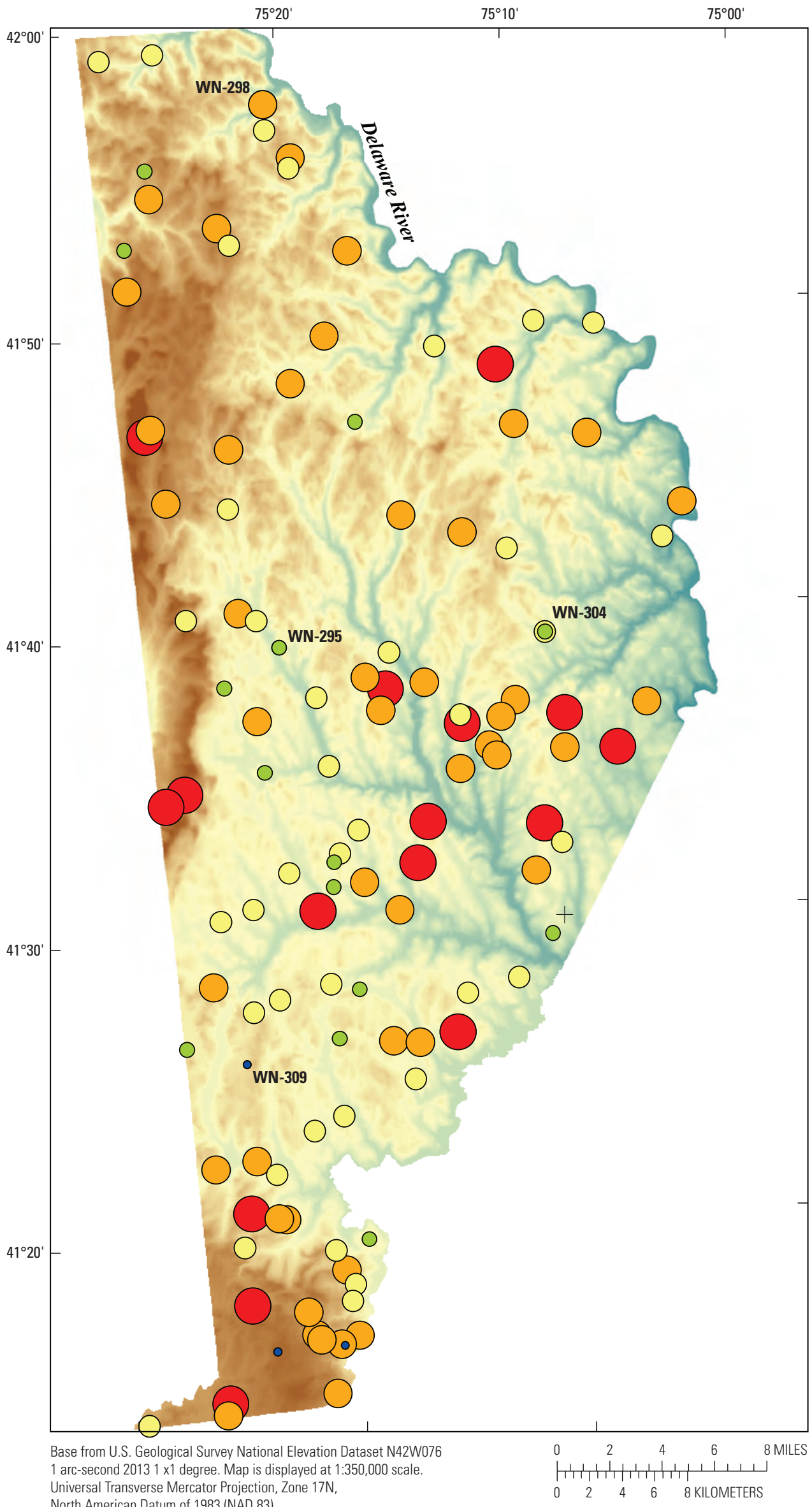

\section{EXPLANATION}

Land-surface elevation above NAVD 88

- High: 807 meters (2,648 feet)

Mid: 446 meters (1,463 feet)

Low: 201 meters (659 feet)

Radon-222, in picocuries per liter

- 0 to 300

301 to 1,000

1,001 to 2,000

2,001 to 4,000

4,001 to 7,400

Figure 16. Spatial distribution of radon-222 activities

(concentrations) in water samples collected from 89 wells in 2014 and 32 wells in 2013 in Wayne County, Pennsylvania. For four wells (WN295, 298, 304, and 309) sampled twice, results for 2014 are plotted on top of results for 2013. 


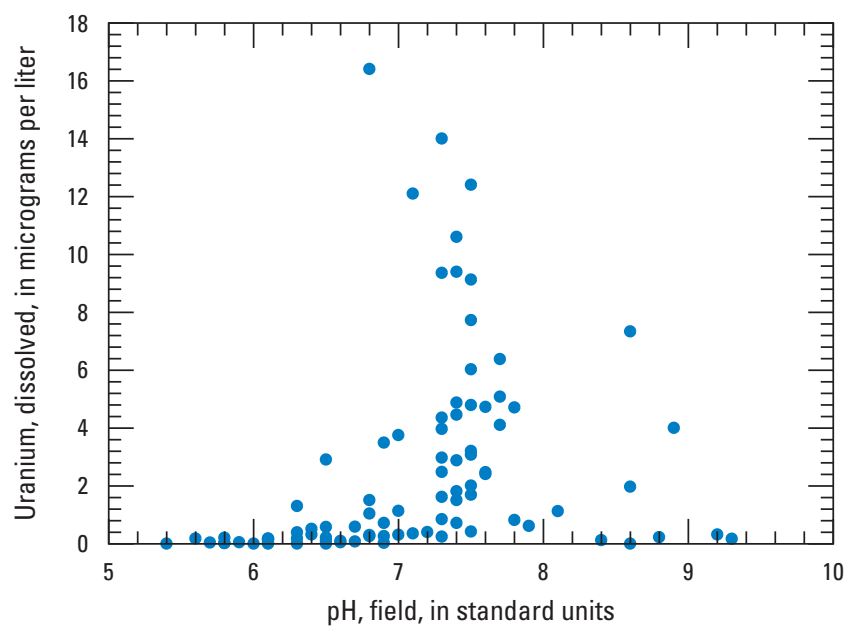

Figure 17. Dissolved uranium concentrations in relation to field measured $\mathrm{pH}$ in water samples collected from 89 wells in Wayne County, Pennsylvania, July-September 2014.

and others, 2012). Sources of methane may be inferred from the isotopic composition of the methane itself and from the presence of other gases on the basis of numerous studies described in Breen and others (2007).

Although the presence of methane in well water is not known to pose a health risk through ingestion, methane at sufficient concentrations in well water may increase the hazard of explosion when vented into a confined space (Eltschlager and others, 2001). Recommended action levels for methane concentrations in well water listed in table 7 are guidelines, but site-specific conditions need to be considered when evaluating potential risks (Eltschlager and others, 2001).

Water samples from 89 wells were analyzed for the hydrocarbon gases methane, ethane, and propane by a contract laboratory (Environmental Services Laboratory, Inc.) using method PADEP 3686, but only methane was detected. Methane was measured in concentrations greater than the laboratory reporting level of $0.24 \mathrm{mg} / \mathrm{L}$ in samples from 8 of 89 wells (9 percent), ranging from 0.74 to $9.6 \mathrm{mg} / \mathrm{L}$. Two samples had dissolved methane concentrations $(6.8$ and $9.6 \mathrm{mg} / \mathrm{L})$ near or exceeding the Pennsylvania action level of $7 \mathrm{mg} / \mathrm{L}$ set to minimize hazards related to explosion (Commonwealth of Pennsylvania, 2014).

Ethane and propane, with laboratory reporting levels of 1.24 and $1.42 \mathrm{mg} / \mathrm{L}$, were not detected by the contract laboratory (Environmental Services Laboratory, Inc.) in any of the 89 samples. For the previous assessment, which was based on samples collected in 2011 and 2013 (Sloto, 2014), dissolved gases were determined using a different laboratory and method with lower reporting levels $(0.0006 \mathrm{mg} / \mathrm{L})$ than the laboratory and method (PADEP 3686) used for the 2014 samples $(0.24 \mathrm{mg} / \mathrm{L})$; consequently, methane was detected more frequently and at lower concentrations than in 2014. Sloto (2014) reported that 22 of 34 well-water samples (65 percent) collected in 2011 and 2013 had detectable concentrations of methane, ranging from 0.00012 to $3.3 \mathrm{mg} / \mathrm{L}$, but only 3 of the 34 samples ( 8.8 percent) had methane concentrations greater than $0.24 \mathrm{mg} / \mathrm{L}$ (see also Appendix 1 table A1-1). The spatial distribution of relatively elevated methane concentrations (greater than $0.7 \mathrm{mg} / \mathrm{L}$ ) in Wayne County groundwater is shown in figure 19, which also shows that elevated methane tends to occur with elevated lithium concentrations.

Replicate samples from 16 wells sampled in 2014 were sent to Isotech Laboratories, Inc., for isotopic characterization of methane; for dissolved gas analysis that included methane, ethane, ethylene, propane, propylene, iso-butane, and N-butane; and for the hydrocarbon liquids iso-pentane, N-pentane, and hexane. Seven of the 16 samples sent to Isotech Laboratories, Inc., for dissolved gas analysis had methane concentrations near or greater than $1 \mathrm{mg} / \mathrm{L}$, as previously determined by the contract laboratory method PADEP 3686. Of the hydrocarbon gases analyzed by Isotech Laboratories, Inc., only methane and ethane were detected (table 12, at back of report). Methane concentrations were measured at greater than the reporting level of $0.0003 \mathrm{mg} / \mathrm{L}$ in 15 of 16 samples, with those concentrations ranging from 0.00052 to $9.7 \mathrm{mg} / \mathrm{L}$ (table 8). Ethane was measured at greater than the reporting level of $0.0002 \mathrm{mg} / \mathrm{L}$ in 6 of 16 samples, with those concentrations ranging from 0.00032 to $0.0017 \mathrm{mg} / \mathrm{L}$. Methane concentrations determined by Isotech Laboratories, Inc., were similar to but generally somewhat less (about 10 to 35 percent less in 6 samples and 1 percent higher in 1 sample) than those determined by laboratory method PADEP 3686 (table 8). Differences in results between laboratories may be related to analytical techniques, calibrations, sample-collection methods, or sample containers.

\section{Methane Isotopic Composition and Origin of Methane Gas}

The isotopic composition of methane was determined for eight groundwater samples that had methane concentrations ranging from 0.19 to $9.7 \mathrm{mg} / \mathrm{L}$ (table 12 at back of report). These isotopic compositions of methane in Wayne County groundwater samples plot mostly in the range of compositions for methane gas of known thermogenic origin, with some plotting in the range for methane of microbial origin (formed by carbon dioxide reduction processes) (see well WN-309, fig. 20). Although the isotopic signature of the methane gas in the Wayne County groundwater samples appears to indicate a thermogenic origin, the small amounts of accompanying ethane may be interpreted to infer a microbial origin for the methane (Bernard and others, 1978; Schoell, 1980; Révész and others, 2012).

In samples collected from well WN-309 about 1 year apart, there appears to be a shift toward methane of microbial origin from 2013 to 2014. Other shifts in water quality in WN-309 were indicated, including decreases in barium, boron, bromide, fluoride, and lithium concentrations (constituents 


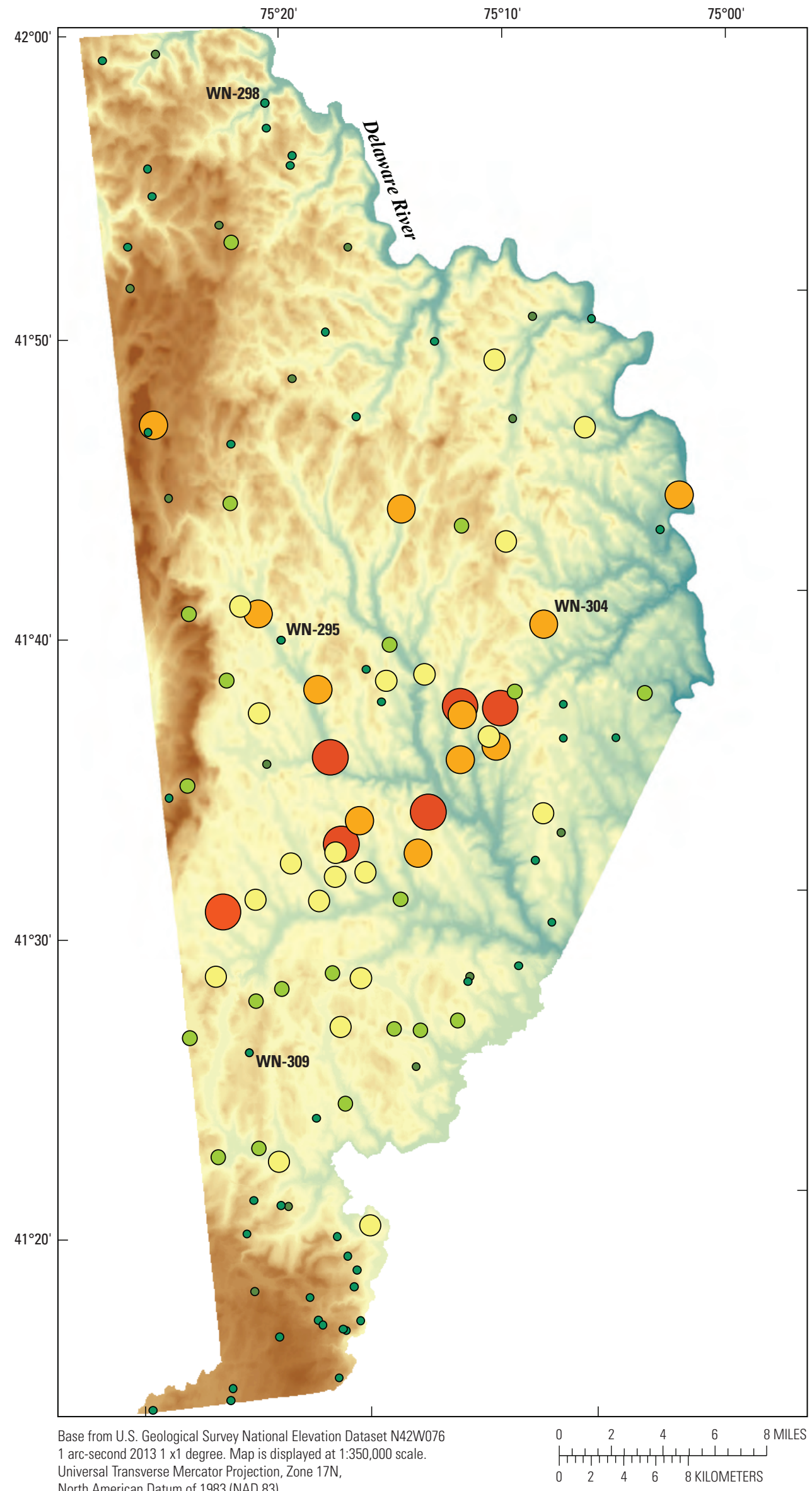

\section{EXPLANATION}

Land-surface elevation above NAVD 88

- High: 807 meters (2,648 feet)

- Mid: 446 meters (1,463 feet)

- Low: 201 meters (659 feet)

Uranium concentration,

in micrograms per liter
- 0 to 1.0
1.1 to 2.5
2.6 to 5.0
5.1 to 10
? 10.1 to 16.4

Figure 18. Spatial distribution of dissolved uranium concentrations in water samples collected from 89 wells in 2014 and 32 wells in 2013 in Wayne County, Pennsylvania. For four wells (WN-295, 298, 304, and 309) sampled twice, results for 2014 are plotted on top of results for 2013. 
Table 6. Reporting levels and drinking-water standards for man-made organic compounds determined in the laboratory for water samples collected from 89 wells in Wayne County, Pennsylvania, July-September 2014.

[ $\mu \mathrm{g} / \mathrm{L}$, micrograms per liter; mg/L, milligrams per liter; \%, percent; MCL, maximum contaminant level; HA, health advisory]

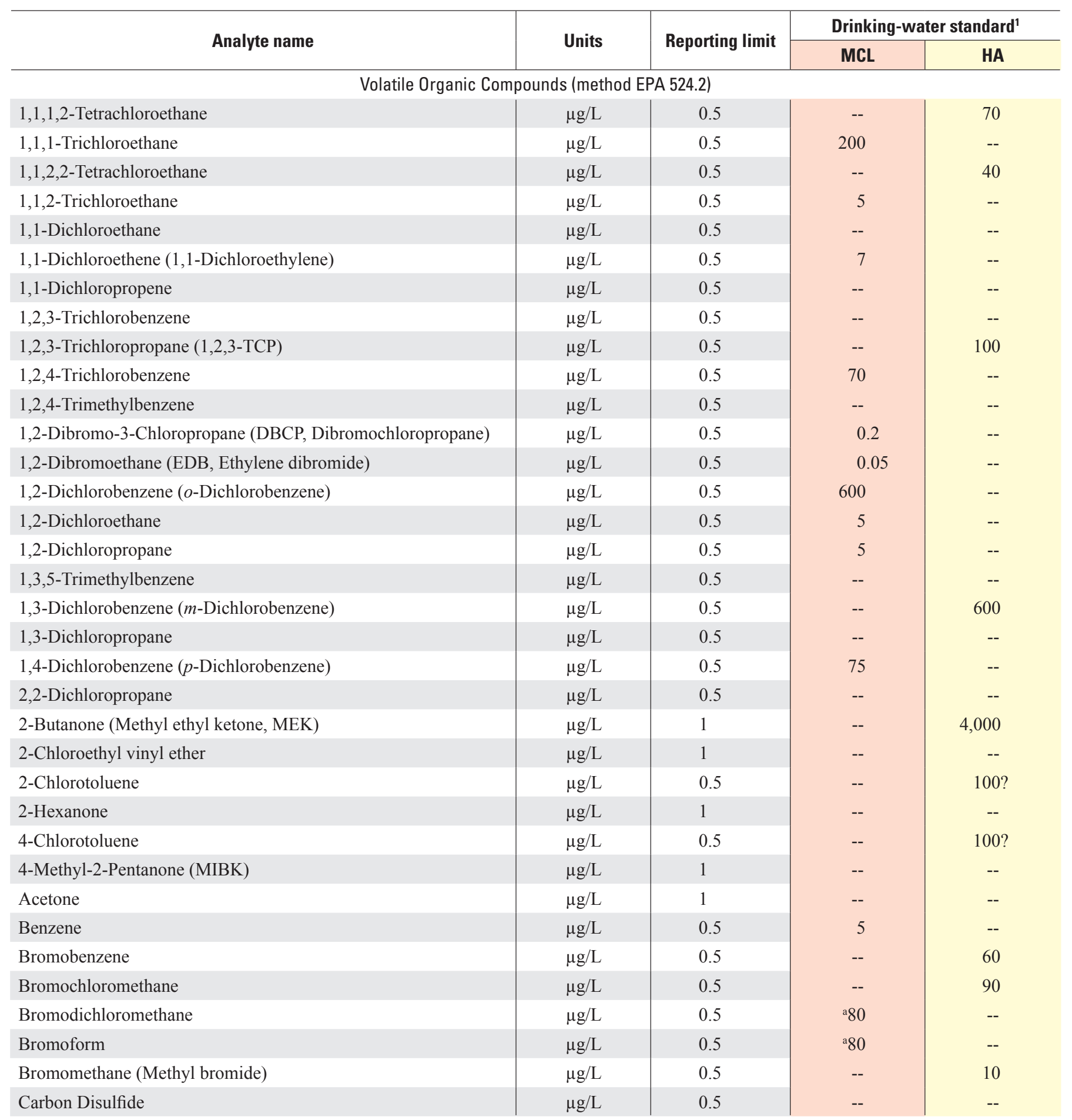


Table 6. Reporting levels and drinking-water standards for man-made organic compounds determined in the laboratory for water samples collected from 89 wells in Wayne County, Pennsylvania, July-September 2014._-Continued

[ $\mu \mathrm{g} / \mathrm{L}$, micrograms per liter; mg/L, milligrams per liter; \%, percent; MCL, maximum contaminant level; HA, health advisory]

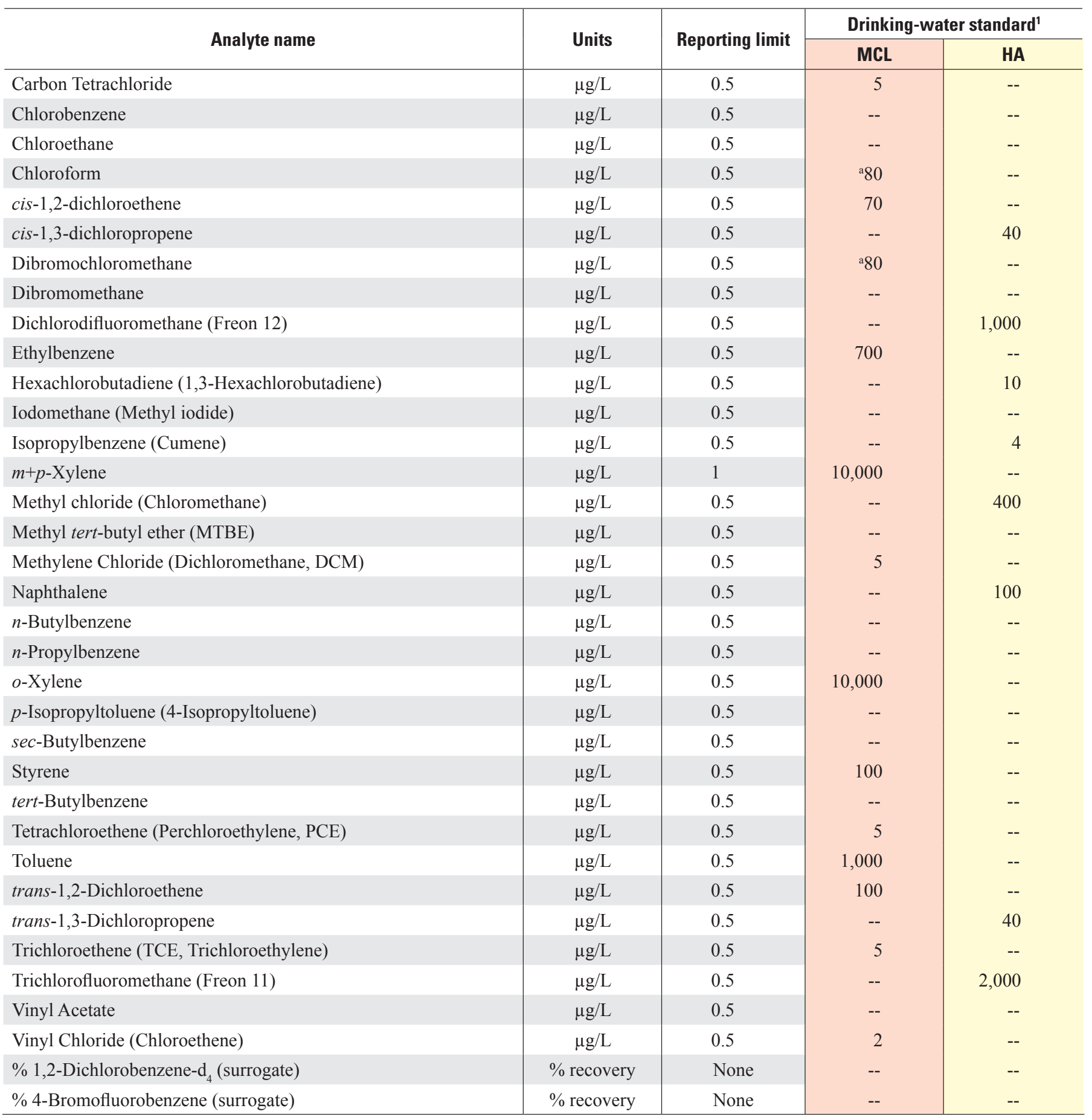


Table 6. Reporting levels and drinking-water standards for man-made organic compounds determined in the laboratory for water samples collected from 89 wells in Wayne County, Pennsylvania, July-September 2014.—Continued

[ $\mu \mathrm{g} / \mathrm{L}$, micrograms per liter; mg/L, milligrams per liter; \%, percent; MCL, maximum contaminant level; HA, health advisory]

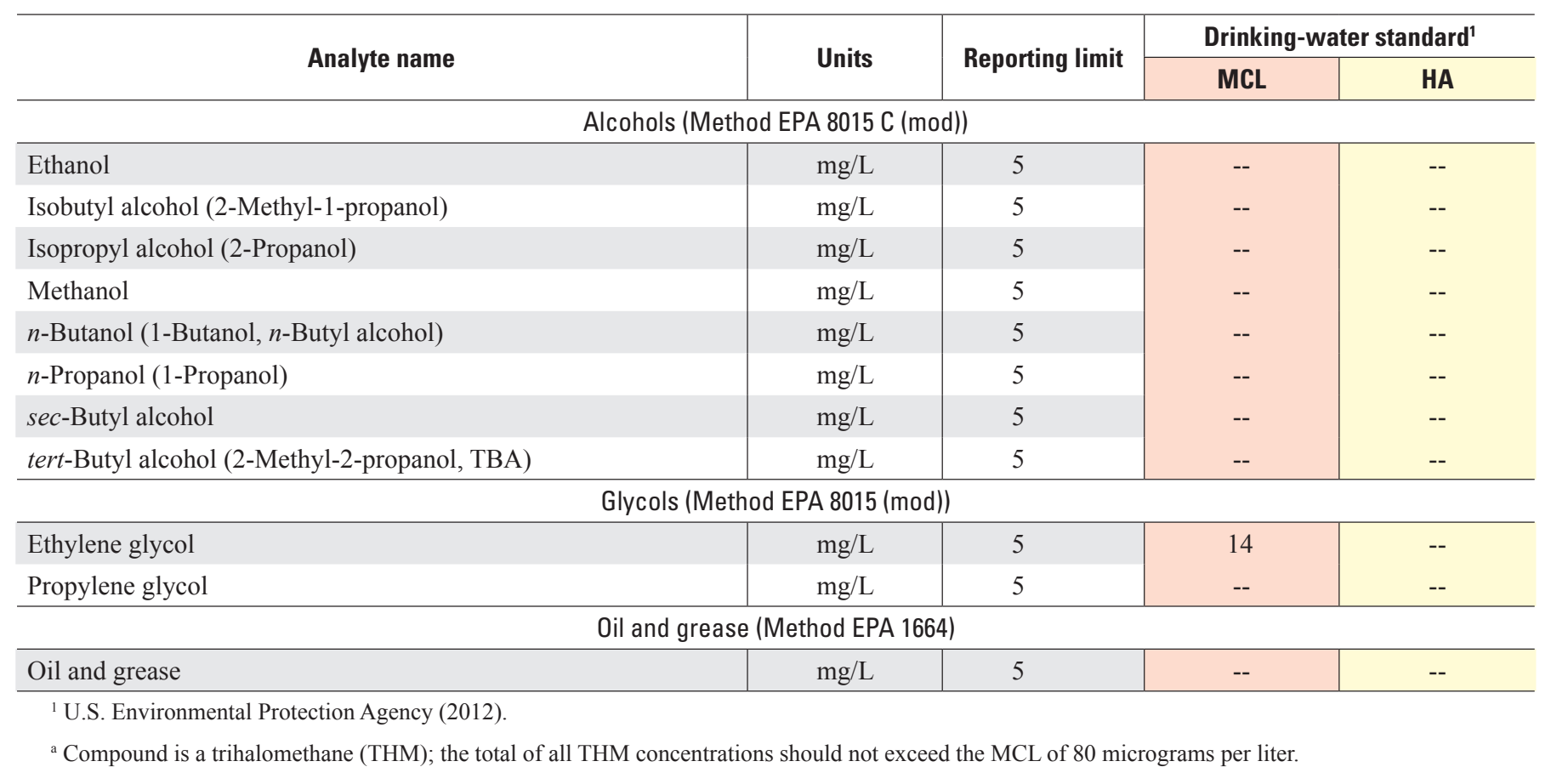

Table 7. Minimum, median, and maximum concentrations of methane, ethane, and propane determined in the laboratory for water samples collected from 89 wells in Wayne County, Pennsylvania, July-September 2014.

[mg/L, milligrams per liter; <, less than; >, greater than; --, no data or not applicable; PADEP, Pennsylvania Department of Environmental Protection]

\begin{tabular}{|c|c|c|c|c|c|c|c|c|c|}
\hline \multirow[b]{2}{*}{$\begin{array}{l}\text { Dissolved } \\
\text { gas }\end{array}$} & \multirow[b]{2}{*}{ Units } & \multirow{2}{*}{$\begin{array}{l}\text { Number } \\
\text { (percent) } \\
\text { above } \\
\text { reporting } \\
\text { level }\end{array}$} & \multicolumn{3}{|c|}{ Concentration range and median } & \multirow{2}{*}{$\begin{array}{l}\text { Number } \\
\text { (percent) } \\
\text { exceeding } \\
\text { standard }\end{array}$} & \multicolumn{3}{|c|}{$\begin{array}{l}\text { Well-water action level' } \\
(\mathrm{mg} / \mathrm{L})\end{array}$} \\
\hline & & & Minimum & Median & Maximum & & Immediate & $\begin{array}{l}\text { Warning- } \\
\text { investigate }\end{array}$ & $\begin{array}{c}\text { No immediate } \\
\text { action- } \\
\text { periodic } \\
\text { monitoring }\end{array}$ \\
\hline \multicolumn{10}{|c|}{ Dissolved gas by Environmental Services Laboratory using PADEP 3686 method (89 samples) } \\
\hline Ethane & $\mathrm{mg} / \mathrm{L}$ & $0(0)$ & $<1.24$ & $<1.24$ & $<1.24$ & $0(0)$ & -- & -- & -- \\
\hline Propane & $\mathrm{mg} / \mathrm{L}$ & $0(0)$ & $<1.42$ & $<1.42$ & $<1.42$ & $0(0)$ & -- & -- & -- \\
\hline
\end{tabular}

\footnotetext{
${ }^{1}$ Recommended action level to minimize the hazard of explosion, with lowest action level of $10 \mathrm{mg} / \mathrm{L}$ (Eltschlager and others, 2001); alternate lowest action level for methane in well water is $7 \mathrm{mg} / \mathrm{L}$ (Commonwealth of Pennsylvania, 2014).

${ }^{a}$ Two samples had methane concentrations $(9.6$ and $6.8 \mathrm{mg} / \mathrm{L})$ at or near the action level of $7 \mathrm{mg} / \mathrm{L}$.
} 


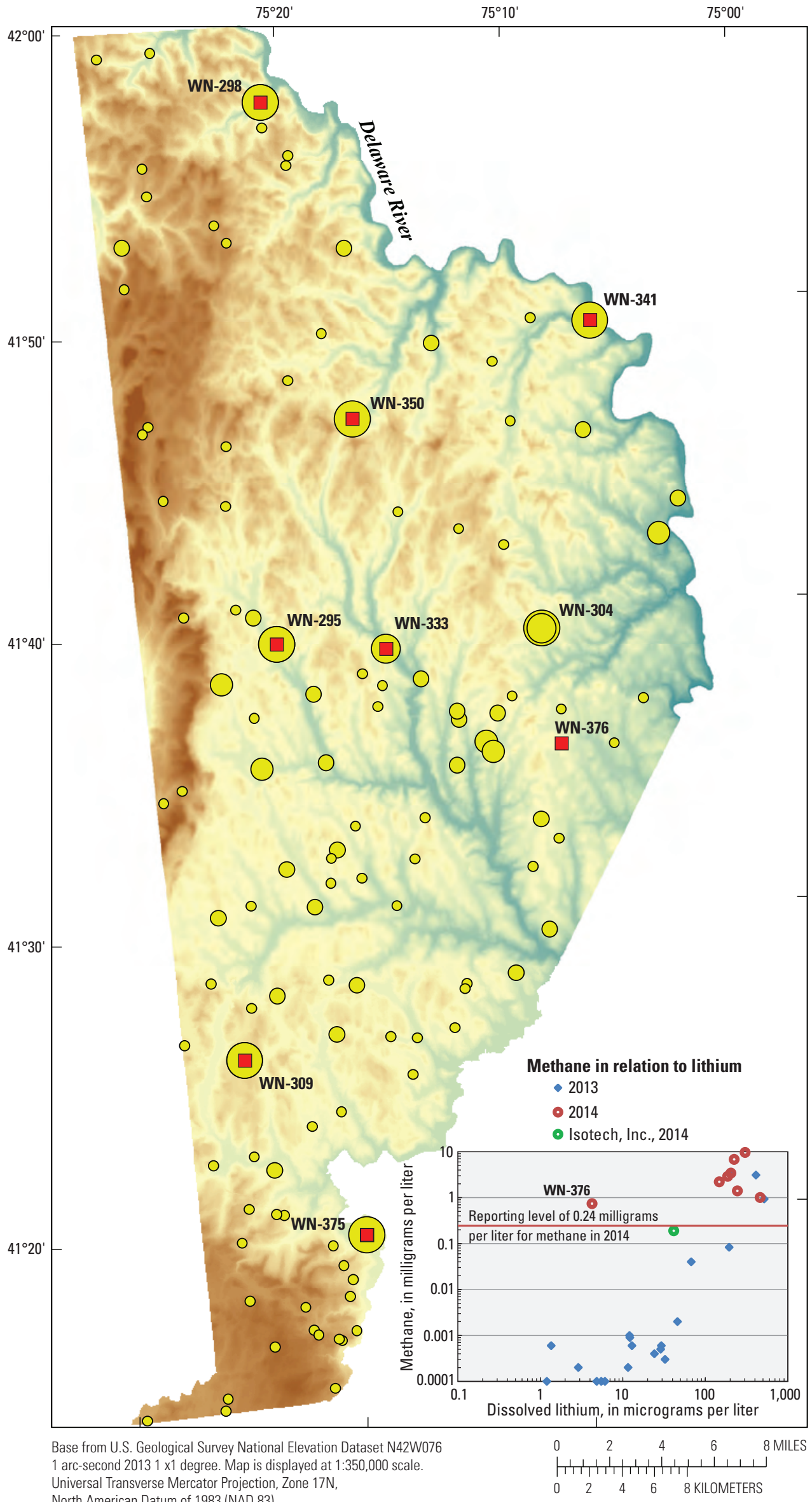

\section{EXPLANATION}

Land-surface elevation above NAVD 88

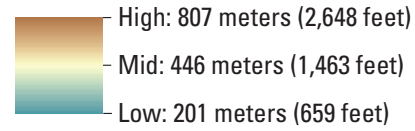

2014 methane concentration,

in milligrams per liter

0.7 to 9.6

2013 and 2014 lithium concentration, in micrograms per liter
○ 0 to 20
20.1 to 50
○ 50.1 to 100
( 100.1 to 150
C 150.1 to 519

Figure 19. Spatial distribution of dissolved lithium and relatively elevated ( $>0.7 \mathrm{mg} / \mathrm{L}$ ) methane concentrations in water samples collected from 89 wells in 2014 and 32 wells in 2013 in Wayne County, Pennsylvania. For four wells (WN-295, 298, 304, and 309) sampled twice, results for 2014 are plotted on top of results for 2013. (mg/L, milligrams per liter) 
Table 8. Concentrations of methane and ethane determined by two laboratories for water samples collected from 8 wells in Wayne County, Pennsylvania, July-September 2014.

[USGS, U.S. Geological Survey; Isotech, Isotech Laboratories, Inc.; ESL, Environmental Services Laboratory, Inc.; <, less than; --, no data or not applicable; $\mathrm{C} 1 / \mathrm{C} 2$ ratio, ratio of methane (c1) to ethane (c2) concentrations; PADEP, Pennsylvania Department of Environmental Protection]

\begin{tabular}{|c|c|c|c|c|c|c|c|}
\hline \multirow{2}{*}{$\begin{array}{l}\text { USGS local } \\
\text { well number }\end{array}$} & \multirow{2}{*}{$\begin{array}{l}\text { Sample } \\
\text { date }\end{array}$} & \multicolumn{4}{|c|}{$\begin{array}{l}\text { Concentrations by laboratory } \\
\text { (milligrams per liter) }\end{array}$} & \multirow{2}{*}{$\begin{array}{l}\text { Ratio of } \\
\text { Isotech } \\
\text { methane to } \\
\text { ESL methane }\end{array}$} & \multirow{2}{*}{$\begin{array}{l}\mathrm{C} 1 / \mathrm{C} \\
\text { ratio }\end{array}$} \\
\hline & & \multicolumn{2}{|c|}{ Isotech } & \multicolumn{2}{|c|}{ ESL $^{1}$} & & \\
\hline \multicolumn{8}{|c|}{ Water samples analyzed for dissolved gas and methane isotopic composition } \\
\hline WN-295 & $8 / 26 / 2014$ & 5.30 & 0.0010 & 6.8 & $<1.2$ & 0.78 & 5,300 \\
\hline WN-309 & $9 / 16 / 2014$ & 0.76 & 0.0013 & 1.0 & $<1.2$ & 0.76 & 585 \\
\hline WN-333 & $7 / 23 / 2014$ & 1.5 & 0.00032 & 2.2 & $<1.2$ & 0.68 & 4,688 \\
\hline WN-339 & $7 / 28 / 2014$ & 0.19 & $<0.0002$ & $<0.24$ & $<1.2$ & -- & -- \\
\hline WN-341 & $7 / 31 / 2014$ & 9.70 & 0.0017 & 9.6 & $<1.2$ & 1.01 & 5,706 \\
\hline WN-350 & $8 / 5 / 2014$ & 2.8 & 0.00054 & 3.4 & $<1.2$ & 0.82 & 5,185 \\
\hline \multicolumn{8}{|c|}{ Water samples analyzed for dissolved gas concentrations only } \\
\hline WN-327 & $7 / 16 / 2014$ & 0.0034 & $<0.0002$ & $<0.24$ & $<1.2$ & -- & \\
\hline WN-329 & $7 / 21 / 2014$ & $<0.0002$ & $<0.0002$ & $<0.24$ & $<1.2$ & -- & \\
\hline WN-355 & $8 / 5 / 2014$ & 0.00035 & $<0.0002$ & $<0.24$ & $<1.2$ & -- & \\
\hline WN-385 & $9 / 9 / 2014$ & 0.0013 & $<0.0002$ & $<0.24$ & $<1.2$ & -- & \\
\hline WN-388 & 9/9/2014 & 0.0011 & $<0.0002$ & $<0.24$ & $<1.2$ & -- & \\
\hline WN-389 & $9 / 10 / 2014$ & 0.00074 & $<0.0002$ & $<0.24$ & $<1.2$ & -- & \\
\hline
\end{tabular}

${ }^{1}$ Methane determined by PADEP 3686 method.

commonly associated with elevated methane in Wayne County groundwater) from 2013 to 2014 . The differences in water quality and isotopic composition of methane between the 2013 and 2014 samples from WN-309 indicate that these water samples represent mixtures from multiple water-bearing zones that may differ in composition or in relative contributions of water through time.

Another scheme used to characterize methane by origin and type is shown in figure 21, which focuses on the boundaries between thermogenic and microbial methane formed by carbon dioxide reduction and displays methane compositions in Wayne County groundwater and those reported for gas derived from the geologic formations that underlie the study area (although gas samples are from elsewhere in Pennsylvania). In this scheme, shown in figure 21A, methane in the groundwater samples from Wayne County plots in the thermogenic, mixed, and microbial (carbon dioxide reduction) ranges, in addition to an unnamed field (sample from well WN-375), similar to the scheme presented in figure 20. The isotopic composition of two groundwater samples (from wells $\mathrm{WN}-341$ and $\mathrm{WN}-350$ ) in the thermogenic field (fig. 21A) is similar to the mean composition reported for methane gas in mud-logging samples from the Catskill and Lock Haven Formations (undifferentiated) during drilling of Marcellus Shale gas wells in Pennsylvania (Baldassare and others, 2014). As gas matures or originates from greater depths, the isotopic composition of methane apparently becomes heavier, as shown by the composition of Marcellus gas samples in figure 21A (Baldassare and others, 2014). However, shifts in isotopic composition related to gas maturation and oxidation are similar. Some methane in the Wayne County groundwater samples may have been affected by oxidation, which would cause the remaining methane to become more enriched with heavier isotopes (a less negative composition), such as the two samples from WN-339 and WN-375; the methane in these samples possibly is of microbial or mixed origin that has been oxidized (fig. 21A). Oxidation of the methane may not be occurring at locations in the aquifer where elevated methane concentrations were measured in the groundwater; all samples with methane concentrations $>0.7 \mathrm{mg} / \mathrm{L}$ had very low oxygen concentrations $(<0.5 \mathrm{mg} / \mathrm{L})$. A previous study (Breen and others, 2007) indicates that the values for isotopic composition 
of dissolved inorganic carbon, $\delta^{13} \mathrm{C}_{\mathrm{DIC}}$, would be near $-25 \%$ if oxidation of methane were an active process in the groundwater. Limited data for $\delta^{13} \mathrm{C}_{\mathrm{DIC}}$ (values ranged from -16 to $-10 \%$ in samples from three wells) in nearby Pike County groundwater (Senior, 2014), which is similar in composition to Wayne County groundwater, indicate that oxidation of methane is not an active process where methane in groundwater was measured but could have occurred elsewhere in the aquifer. Data on $\delta^{13} \mathrm{C}_{\mathrm{DIC}}$ were not collected for the Wayne County study but, if available, may provide additional information about the possible origin of, and processes affecting, methane in groundwater in Wayne County.

The ratio of methane to higher chain carbon compounds (commonly denoted as $\mathrm{C} 1 / \mathrm{C} 2$ for ratio of methane to ethane or $\mathrm{C} 1 / \mathrm{C} 2+$ for ratio of methane to sum of all higher chain carbon compounds) has been used to identify the origins of methane; the ratio also is a measure of gas "wetness," with larger amounts of $\mathrm{C} 2+$ compounds in wetter gas. Methane accompanied by low concentrations of ethane and higher chain carbon compounds commonly is called "dry gas."

$\mathrm{C} 1 / \mathrm{C} 2+$ ratios (calculated for gases reported in units of volume or molar percent) greater than 1,000 have been reported to indicate microbial origins and ratios less than 1,000 to indicate thermogenic origins (Taylor and others, 2000). The $\mathrm{C} 1 / \mathrm{C} 2$ ratios (computed from reported mole percent of gases) for the six Wayne County groundwater samples with detectable ethane were all greater than 1,000 , indicating a predominantly microbial origin for the methane or a derivation from thermogenic natural gas that is depleted in ethane for other reasons, such as relative depletion of ethane as part of gas maturation or migration (Coleman and others, 1995).

The isotopic composition and methane/ethane $(\mathrm{C} 1 / \mathrm{C} 2)$ ratios for gas dissolved in the Wayne County groundwater samples do not definitely characterize the source of the methane gas. The available evidence indicates that the methane in groundwater appears to be predominantly of microbial origin and has undergone various amounts of oxidation. Alternatively, methane in some of the samples may be thermogenic but from a source relatively depleted in ethane. Organic material within the Catskill Formation and other Devonian-age deposits in northern Pennsylvania may be a source of "dry-gas" methane (Wilson, 2014). Use of both the isotopic composition of methane and $\mathrm{C} 1 / \mathrm{C} 2$ ratios may be helpful in distinguishing existing baseline gas in groundwater from gas that might be introduced through shale-gas development. Additional data, such as analyses for carbon-14 (for age dating) of methane and for $\delta^{13} \mathrm{C}_{\mathrm{DIC}}$, discussed previously, might be useful to further characterize the origin and fate of methane in groundwater in Wayne County and elsewhere.

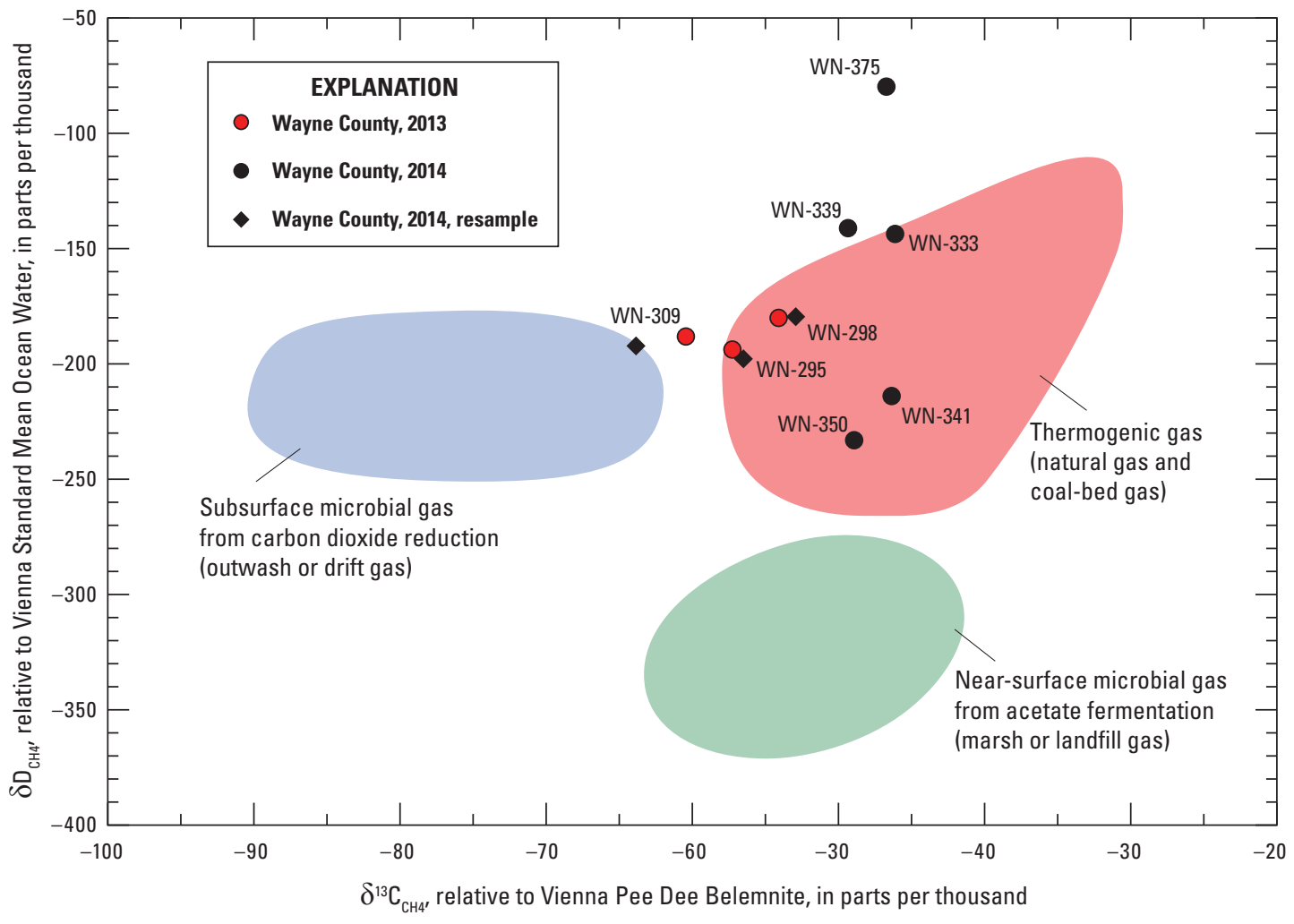

Figure 20. Isotopic composition of methane in water samples collected from eight wells in 2014, Wayne County, Pennsylvania. Three of the 8 wells sampled in 2014 also were sampled in 2013. 


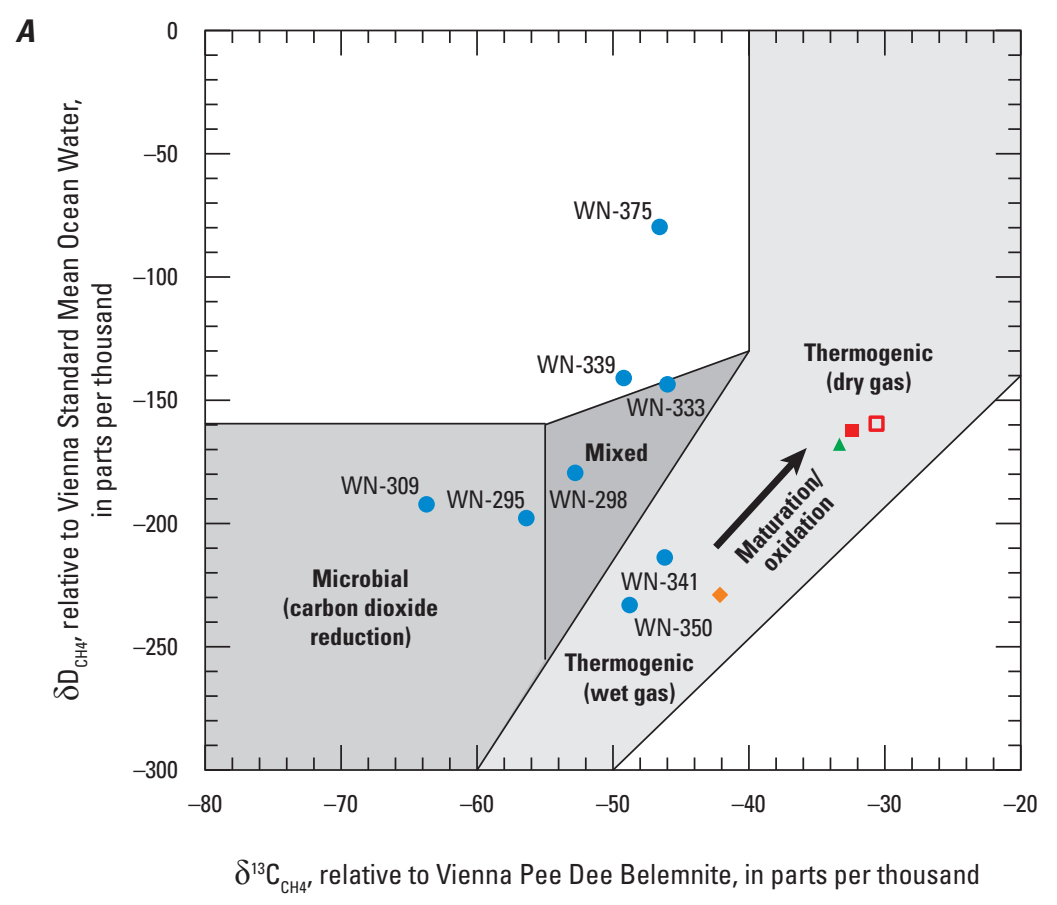

\author{
EXPLANATION \\ Isotopic composition of methane gas in groundwater \\ - Wayne County groundwater sample, 2014 \\ Mean isotopic composition of methane gas from mud gas \\ logging of shale-gas wells in Pennsylvania \\ (Baldassare and others, 2014) \\ - Catskill/Lockhaven Formation \\ $\Delta \quad$ Hamilton Group \\ - Marcellus Formation
}

Methane gas composition, Susquehanna County (Reese and others, 2014)

Marcellus Formation

B

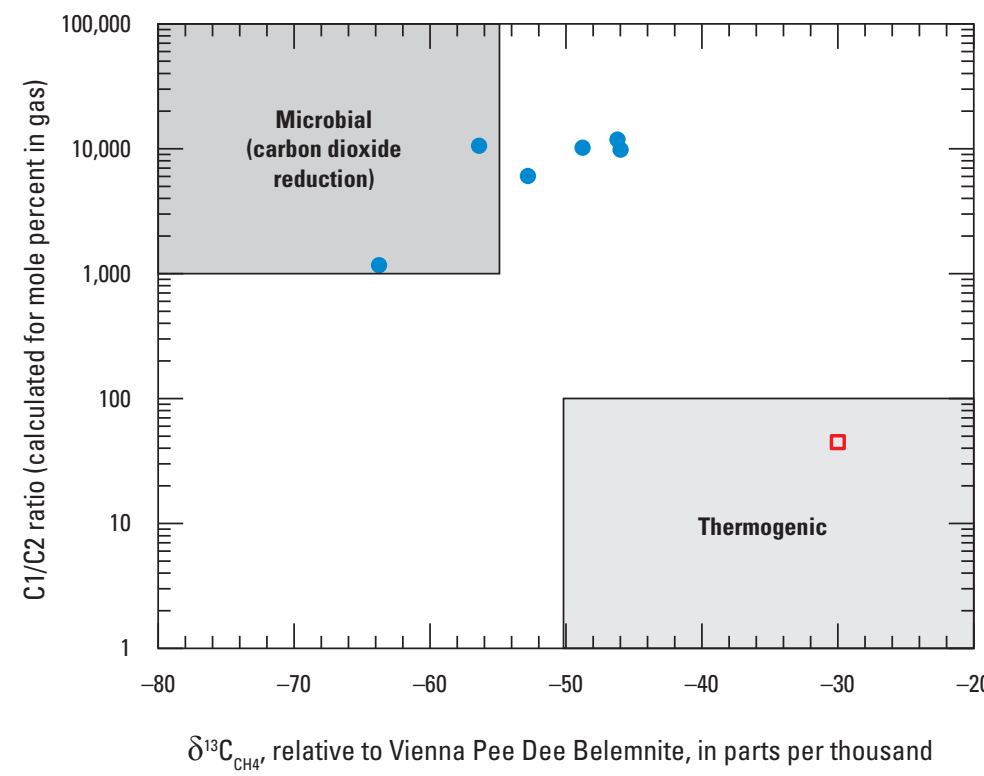

EXPLANATION

Isotopic composition of carbon in methane gas and methane/ethane (C1/C2) ratio

- Wayne County groundwater sample, 2014

․ Marcellus Formation methane gas, Susquehanna County (Reese and others, 2014)

Figure 21. A, Isotopic composition of methane in water samples collected from eight wells in Wayne County, Pennsylvania, 2014, and in mud-logging gas samples collected from different geologic formations during drilling of Marcellus Shale gas wells in Pennsylvania, and $B, C 1 / C 2$ (methane/ethane) ratios in relation to carbon-isotopic composition for methane in these same samples. Compositional shift related to gas maturation/oxidation show by arrow. Boundaries of gas types from Reese and others (figure 30, p. 38, 2014) and mud-logging gas data from Baldassare and others (2014). 


\section{Geochemical Modeling and Analysis of Water Quality Data}

To assist in understanding why certain constituents are present in the groundwater and the spatial distribution of water quality, geochemical modeling and other analyses of data were done to provide insight on processes affecting or controlling water quality throughout Wayne County. Water-quality data from 2013 and 2014 were combined to create an extensive dataset for these analyses, which included characterization of the groundwater by (1) type through Piper diagrams (major ion composition), (2) ratios of chloride to bromide and sodium to provide insight on origins of chloride, (3) correlations among constituents to identify patterns in constituent associations, (4) geochemical modeling of mineral saturation indices to identify minerals that affect groundwater composition through dissolution or precipitation, and (5) geochemical modeling of dissolution, exchange, and mixing processes that might explain observed water quality. In this section, a conceptual model of how groundwater quality evolves is presented, and the spatial distribution of groundwater quality throughout Wayne County is discussed.

The groundwater samples collected in Wayne County in 2014 provided patterns of associations among constituents. For example, groundwater with lower $\mathrm{pH}$ tended to be the most dilute and have higher DO concentrations, whereas groundwater with higher $\mathrm{pH}$ tended to have higher concentrations of TDS, selected major ions, and inorganic trace constituents. Groundwater with relatively elevated methane concentrations differed in composition from that of groundwater with low methane concentrations. The seven well-water samples in 2014 with the highest methane concentrations (from about 1 to $9.6 \mathrm{mg} / \mathrm{L}$ ) also had among the highest $\mathrm{pH}$ values (8.1 to 9.3) and concentrations of sodium, lithium, boron, fluoride, arsenic, and bromide (fig. 22, table 11). Relatively elevated concentrations of some other constituents, such as barium, strontium, and chloride, commonly were present in, but not limited to, well-water samples with elevated methane in Wayne County. Similar patterns in constituent associations were noted for groundwater samples collected in Wayne County in 2013 and in two other counties with similar geologic units-Pike County in 2012 (Senior, 2014) and Sullivan County in 2012 (Sloto, 2013). Identification of associations among constituents leads to improved understanding of processes controlling the existing water quality that may be useful for predicting where existing water-quality problems are likely to occur and in determining possible effects related to possible future shalegas development or other changes in land use. Some of these associations also may be related to effects of current land-use activities that may contribute specific constituents (such as salts and nutrients from deicing roads and septic systems) to groundwater.

\section{Types of Groundwater as Characterized by Major lons}

The relative proportions of major ions in water samples may be used to distinguish different types of water, as shown on trilinear (Piper) diagrams (fig. 23A). Major cations are calcium, magnesium, and sodium (and potassium which usually is less than, but plotted with, the sodium component). Major anions are bicarbonate $\left(\mathrm{HCO}_{3}^{-}\right)$, sulfate, and chloride (and nitrate and fluoride, both of which are plotted with, but usually are less than, the chloride component). The major ion composition of 121 water samples collected during 2013 and 2014 from 117 wells (four wells were sampled in 2013 and 2014) in Wayne County as plotted on a Piper diagram (fig. 23B) is predominantly calcium-bicarbonate (more than 50 percent calcium and bicarbonate as cations and anions, respectively). A few samples (15 of 117 or about 13 percent) plot as much higher in sodium than the other samples and can be categorized as sodium-bicarbonate-type waters (fig. 23B). The compositions of Wayne County groundwater samples are plotted in figure 23B using different symbols to distinguish ranges in SC, with the most dilute waters (lowest SC, less than $150 \mu \mathrm{S} / \mathrm{cm}$ ) having calcium/bicarbonate to mixed calcium/ bicarbonate-chloride-sulfate composition. The SC is directly and linearly related to TDS in the Wayne County samples (fig. 8), so that ranges in SC correspond to ranges in TDS concentrations; for Wayne County groundwaters, a SC of $150 \mu \mathrm{S} / \mathrm{cm}$ is equivalent to about $95 \mathrm{mg} / \mathrm{L} \mathrm{TDS}$, and a $\mathrm{SC}$ of $425 \mu \mathrm{S} / \mathrm{cm}$ is approximately equivalent to the SMCL of $250 \mathrm{mg} / \mathrm{L}$ TDS. Intermediate SC [150 to $300 \mu \mathrm{S} / \mathrm{cm}$ (TDS of 95 to $180 \mathrm{mg} / \mathrm{L}$ )] waters had mostly calcium/bicarbonate type composition, and the highest SC [300 to $450 \mu \mathrm{S} / \mathrm{cm}$ (TDS of 180 to $265 \mathrm{mg} / \mathrm{L}$ ) and 450 to $700 \mu \mathrm{S} / \mathrm{cm}$ (TDS of 265 to $405 \mathrm{mg} / \mathrm{L}$ )] waters had mostly sodium/bicarbonate to mixed sodium/bicarbonate-chloride type composition (fig. 23B). The compositions of brines and Marcellus flowback (sodium/chloride type) are also plotted for comparison on the Piper diagram (fig. 23B), which shows the composition of Wayne County groundwater samples.

Representative samples are identified on the Piper diagram in order to explain their characteristics and possible origins (fig. 23C). Well-water samples from WN-371, $\mathrm{WN}-345$, and WN-361 are classified as calcium/bicarbonate types, which can be produced simply by the dissolution of calcite. Two of these samples (from wells WN-345 and WN-371) were relatively dilute and acidic (SC less $81 \mu \mathrm{S} /$ $\mathrm{cm}$ at $25^{\circ} \mathrm{C}$, TDS less than $36 \mathrm{mg} / \mathrm{L}$, pH less than 6.2), indicating small amounts of mineral dissolution, and the third sample (from well WN-361) had intermediate TDS and $\mathrm{pH}$ $(177 \mathrm{mg} / \mathrm{L}$ and 7.1 , respectively), indicating greater amounts of mineral dissolution. The characteristics of the very dilute, acidic sample from well WN-345 (SC of $40 \mu \mathrm{S} / \mathrm{cm}$ at $25^{\circ} \mathrm{C}$ and low $\mathrm{pH}$ of 5.8) could have been formed by evaporation of rainwater (recharge), with minor additions of sulfate (from pyrite, gypsum, or other sources) and limited dissolution of calcite. Water samples from wells WN-300 and WN-309 with 

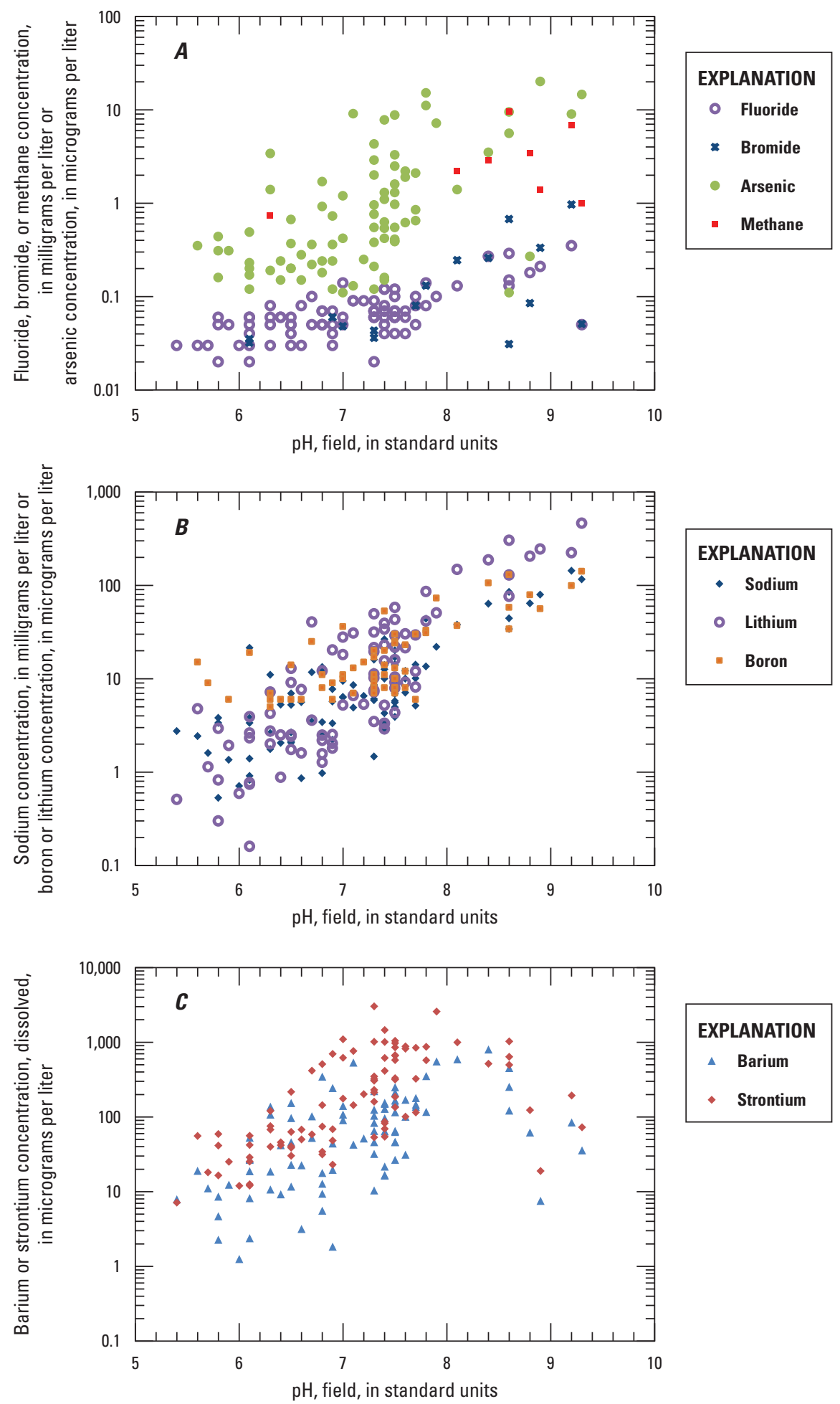

\section{EXPLANATION \\ $\triangle$ Barium \\ - Strontium}

Figure 22. Relation of field measured $\mathrm{pH}$ to dissolved $A$, arsenic, bromide, fluoride, and methane concentrations, $B$, sodium, lithium, and boron concentrations, and $C$, barium and strontium concentrations in water samples collected from 89 wells in Wayne County, Pennsylvania, July-September 2014. 
A. Water Type or Hydrochemical Facies

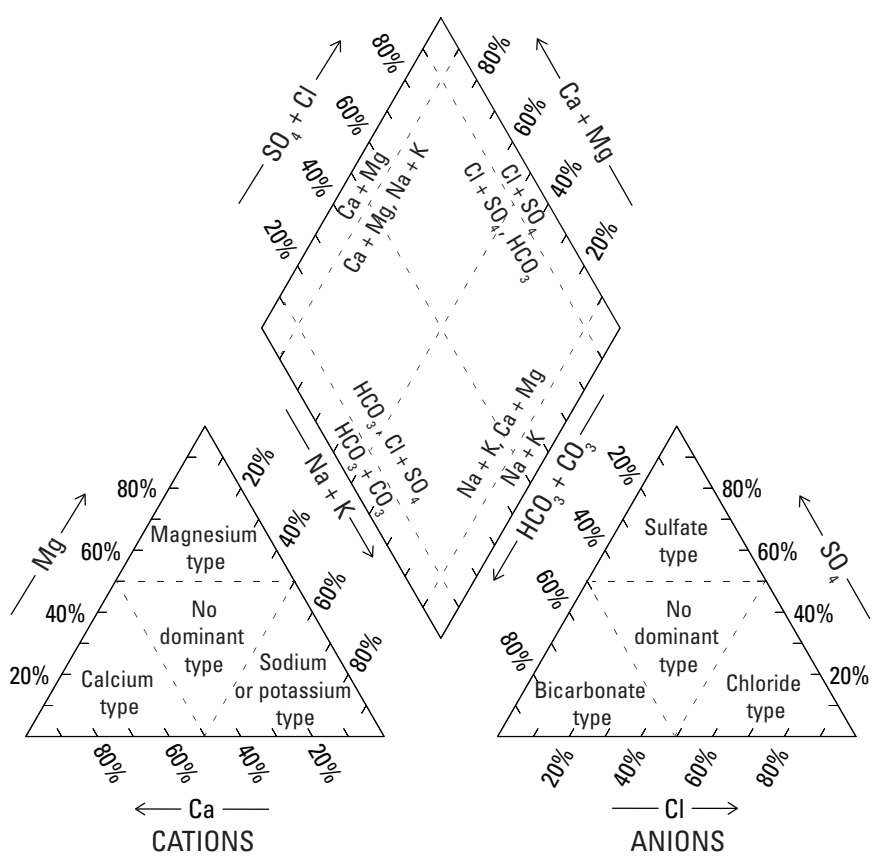

PERCENTAGE OF TOTAL MILLIEQUIVALENTS PER LITER

B. Wayne County Groundwater 2013 and 2014

EXPLANATION

\section{Groundwater}

- $40<\mathrm{SC}<150$ microsiemens per centimeter

- $150 \leq \mathrm{SC}<300$ microsiemens per centimeter

$300 \leq \mathrm{SC}<450$ microsiemens per centimeter

$450 \leq \mathrm{SC}<700$ microsiemens per centimeter

Oil and gas well brine (from Dresel and Rose, 2010)

Flowback water (from Hayes, 2009)
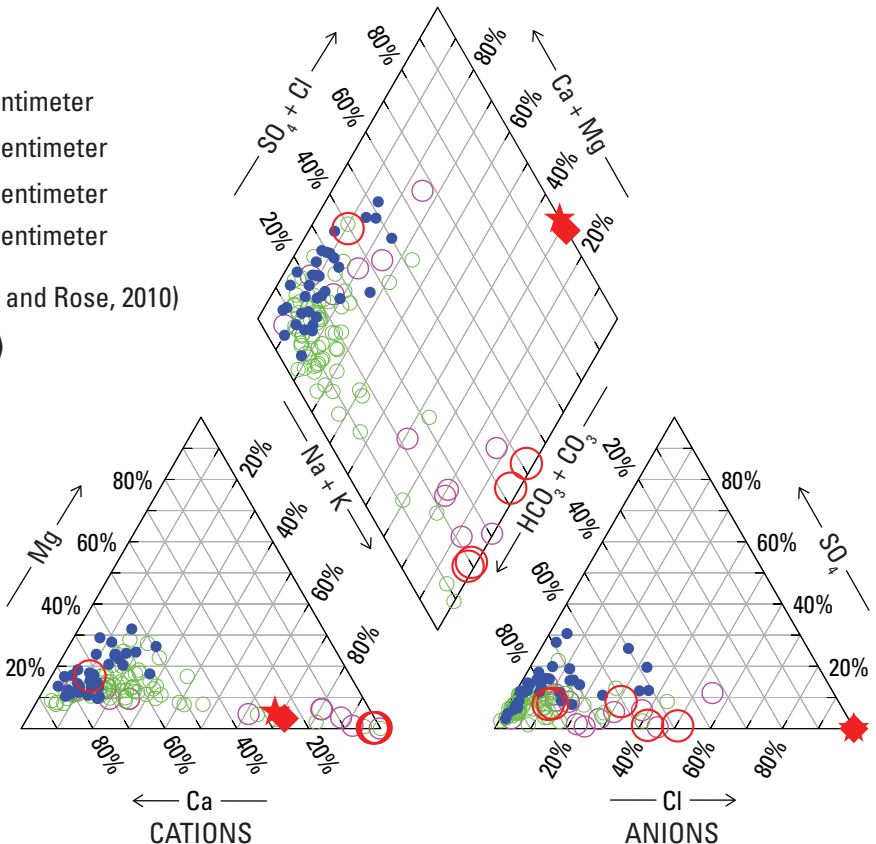

PERCENTAGE OF TOTAL MILLIEQUIVALENTS PER LITER

Figure 23. Major ion composition for $A$, predominant water types or hydrochemical facies, $B$, water samples collected from 117 wells in Wayne County, Pennsylvania, 2013-14 plus median composition of brine from oil and gas wells in western Pennsylvania and flowback water from Marcellus Shale gas wells, $C$, 11 selected groundwater samples from Wayne County, 2013-14, and D, evolution pathways for mixing of dilute $\mathrm{Ca}-\mathrm{HCO}_{3}$ groundwater with road salt; with brine; with brine combined with cation exchange; or with brine plus calcite dissolution to saturation and then cation exchange. Evolution pathways computed for groundwater sample WN-371 mixed in varying proportions with median composition for brine and for the same initial groundwater sample with varying amounts of road salt (with composition $\mathrm{NaCl}_{0.99996} \mathrm{Br}_{0.00004}$ ). (TDS, total dissolved solids; <, less than; $\leq$, less than or equal to; mg/L milligrams per liter; SC, specific conductance) 


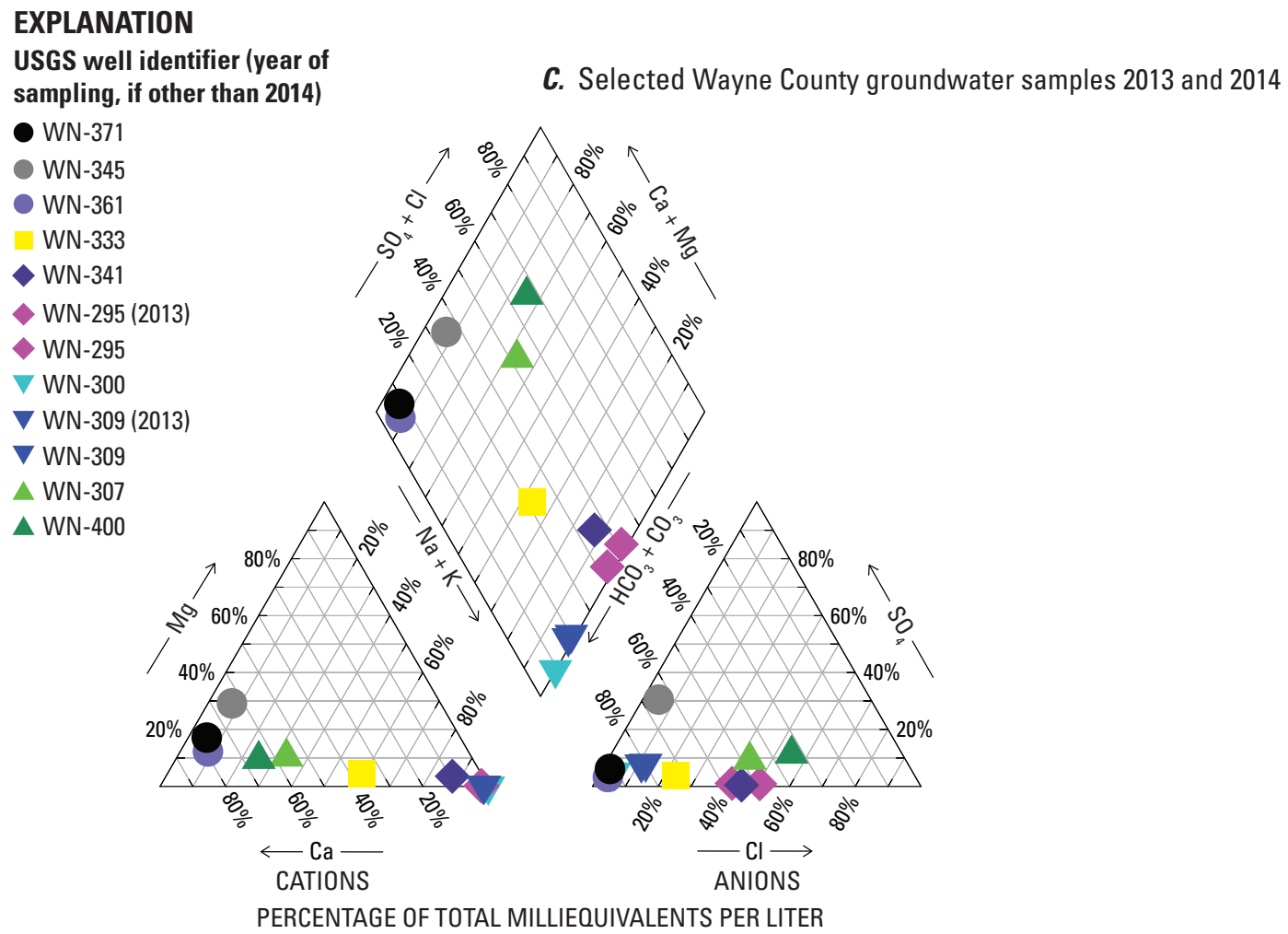

\section{EXPLANATION}

D. Evolution pathways computed for GW+Roadsalt; GW+Brine;
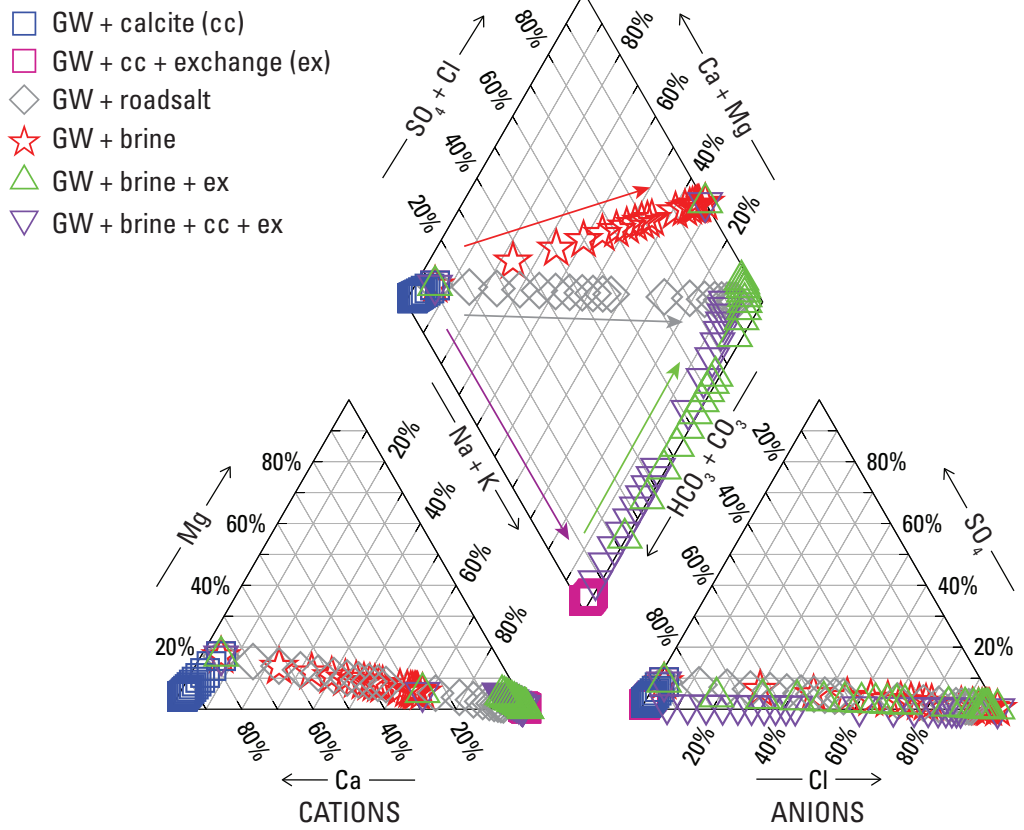

PERCENTAGE OF TOTAL MILLIEQUIVALENTS PER LITER

Figure 23. Major ion composition for $A$, predominant water types or hydrochemical facies, $B$, water samples collected from 117 wells in Wayne County, Pennsylvania, 2013-14 plus median composition of brine from oil and gas wells in western Pennsylvania and flowback water from Marcellus Shale gas wells, $C, 11$ selected groundwater samples from Wayne County, 2013-14, and $D$, evolution pathways for mixing of dilute $\mathrm{Ca}-\mathrm{HCO}_{3}$ groundwater with road salt; with brine; with brine combined with cation exchange; or with brine plus calcite dissolution to saturation and then cation exchange. Evolution pathways computed for groundwater sample WN-371 mixed in varying proportions with median composition for brine and for the same initial groundwater sample with varying amounts of road salt (with composition $\mathrm{NaCl}_{0.99996} \mathrm{Br}_{0.00004}$ ) (TDS, total dissolved solids; $<$, less than; $\leq$, less than or equal to; $\mathrm{mg} / \mathrm{L}$ milligrams per liter; $\mathrm{SC}$, specific conductance)-Continued 
intermediate to high TDS (106 and $294 \mathrm{mg} / \mathrm{L}$, respectively) are classified as sodium/bicarbonate types. Samples from WN-333 and WN-295 with relatively high TDS (172 and 370 $\mathrm{mg} / \mathrm{L}$, respectively) and elevated chloride $(27.5$ and $117 \mathrm{mg} / \mathrm{L}$, respectively) are classified as sodium/bicarbonate-chloride types, where the chloride could be from road-deicing compounds, sewage, animal waste, or possibly brine of geological origin. Finally, samples from WN-307 and WN-400 with intermediate to high TDS (131 and $288 \mathrm{mg} / \mathrm{L}$, respectively) are classified as calcium/chloride-bicarbonate or calcium/ bicarbonate-chloride types; these samples contain 30 and 66.7 $\mathrm{mg} / \mathrm{L}$ chloride, respectively, and sodium and minor sulfate, which could be derived from the various mineral or salt sources described above.

The relative contributions of major ions in selected samples of varying ionic strength (as indicated by specific conductance, which is related to the amount of dissolved constituents) and composition are shown in pie charts (fig. 24) to clarify and extend the interpretation of the Piper diagrams (fig. 23). Individual ion conductivities were estimated from dissolved constituent concentrations as the "transport number" (relative contribution of a given ion to the overall conductivity, using methods of McCleskey and others, 2012) after aqueous speciation calculations with PHREEQC (Parkhurst and Appelo, 2013). Water of similar ionic strength (specific conductance) may have different relative ionic compositions. For example, water samples from wells WN-345 and WN-371 differ in relative ionic composition despite both having relatively low specific conductance values of 40 and $80 \mu \mathrm{S} / \mathrm{cm}$ at $25{ }^{\circ} \mathrm{C}$, respectively (figs. $24 \mathrm{~A}, \mathrm{~B}$ ). In the sample from well $\mathrm{WN}-345$, calcium was the predominant cation with successively lesser contributions of magnesium, sodium, hydrogen, and potassium; bicarbonate and sulfate were almost equally predominant anions with successively lesser contributions of chloride, nitrate, and hydroxide $\left(\mathrm{OH}^{-}\right)$. The observation that hydrogen ions contributed more than potassium to the conductivity is consistent with the acidic $\mathrm{pH}$ (5.8) of this sample. In contrast, sample WN-371 had slightly higher $\mathrm{pH}$ of 6.1 and specific conductance of $80 \mu \mathrm{S} / \mathrm{cm}$ at $25^{\circ} \mathrm{C}$, but the relative ionic composition of this sample was dominated by calcium and bicarbonate. Conversely, water of substantially different ionic strength (specific conductance) may have similar relative ionic composition. For example, although the water sample from well WN-361 had substantially higher $\mathrm{pH}$ of 7.5 and specific conductance of $308 \mu \mathrm{S} / \mathrm{cm}$ at $25^{\circ} \mathrm{C}$ than the sample from well $\mathrm{WN}-371$, the relative ionic composition of these two samples was very similar (figs. 23B, C). Many other samples with specific conductance values less than $335 \mu \mathrm{S} / \mathrm{cm}$ at $25^{\circ} \mathrm{C}$ exhibited similar characteristics and would be classified as calcium/bicarbonate waters.

On the other extreme of ionic strengths for the Wayne County groundwater data, the water sample from well WN-295, which had a pH of 9.2 and SC of $668 \mu \mathrm{S} / \mathrm{cm}$ at $25{ }^{\circ} \mathrm{C}$, had predominant contributions of sodium (as cation) and chloride (as anion) to ionic conductivity with lesser contributions of bicarbonate and carbonate ions. The predominance of sodium and chloride ionic conductivities was exhibited mainly by samples with elevated specific conductance but also by some samples with intermediate specific conductance values, such as sample WN-300 (fig. 23C), which had pH of 6.5 and $\mathrm{SC}$ of $170 \mu \mathrm{S} / \mathrm{cm}$ at $25^{\circ} \mathrm{C}$.

Although informative, disadvantages of Piper diagrams and pie charts include the lack of scaling to indicate the ionic strength and the omission of data on other important characteristics such as the $\mathrm{pH}$, redox state, and trace-element concentrations. These other characteristics are helpful in distinguishing the origins of the groundwaters.

\section{Ratios of Chloride, Bromide, and Sodium in Groundwater}

In Wayne County, chloride concentrations greater than a few milligrams per liter in shallow groundwater likely represent the effects of local and distributed land-use activities or potential contributions from naturally occurring deeper, more saline groundwater of regional extent. The concentrations of chloride ( 0.5 to $117 \mathrm{mg} / \mathrm{L}$ ) ranged widely for the groundwater samples collected from 117 wells for this and the previous 2013 study (Sloto, 2014), as did concentrations of two constituents commonly associated with chloride - sodium ( 0.5 to $143 \mathrm{mg} / \mathrm{L}$ ) and bromide $(<0.01$ to $0.97 \mathrm{mg} / \mathrm{L})$. In some samples, the elevated chloride concentrations are associated with elevated concentrations of sodium and, in a few cases, with elevated nitrate and sulfate, which indicates effects from human or animal waste. In other samples, elevated chloride concentrations are associated with relatively elevated bromide concentrations, which could indicate effects from residual brine of geologic origin.

Chloride/bromide ratios can be useful in distinguishing different sources of chloride (Davis and others, 1998; Mullaney and others, 2009; Whittemore, 2007). Bromide, like chloride, is a soluble anion that exhibits conservative transport properties and can be used as a tracer. Some sources of chloride introduced into the environment by human activities, such as salt (sodium chloride, $\mathrm{NaCl}$ ) used for road deicing or present in septic effluent, typically have relatively low amounts of bromide and, consequently, relatively high chloride/bromide mass ratios (Davis and others, 1998).

Recent studies of groundwater quality in nearby Susquehanna County in northeastern Pennsylvania (Warner and others, 2012; Llwellyn, 2014) report groundwater that has relatively elevated concentrations of chloride and chloride/ bromide ratios that indicate possible mixing with higher salinity or brine-type waters; these brine-type waters are postulated to originate from undetermined depths below the freshwater aquifer and mix with shallow, more dilute groundwater. The chloride/bromide mass ratio for saline water (Salt Spring) in Susquehanna County, Pa., is similar to the range of ratios reported for Marcellus Shale flowback waters and oil- and gasfield brines (fig. 25).

Plots of the mass ratio of chloride to bromide $(\mathrm{Cl} / \mathrm{Br})$ and the concentration of bromide or sodium compared to the 
A. $\mathrm{WN}-345 ; \mathrm{SC}=40 ; \mathrm{pH}=5.8$

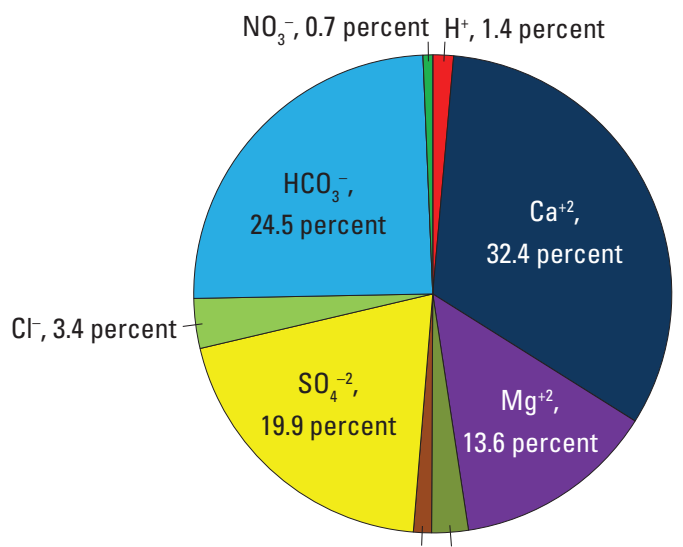

$\mathrm{K}^{+}, 1.2$ percent $\mathrm{Na}^{+}, 2.5$ percent
B. $\mathrm{WN}-371 ; \mathrm{SC}=80 ; \mathrm{pH}=6.1$

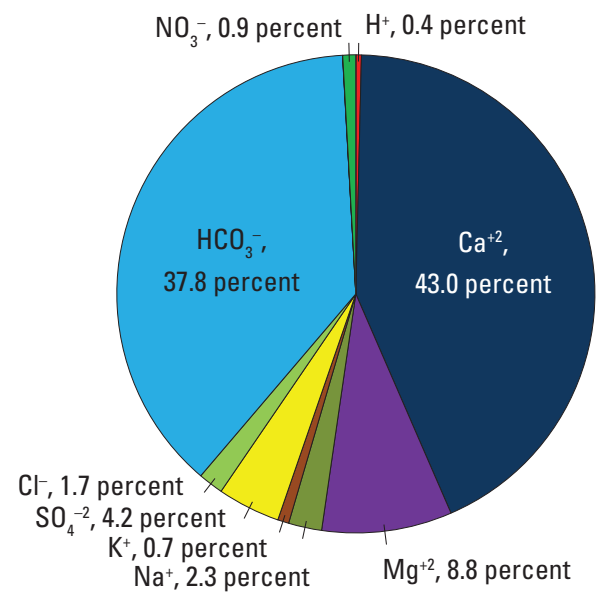

C. $\mathrm{WN}-361 ; \mathrm{SC}=308 ; \mathrm{pH}=7.5$

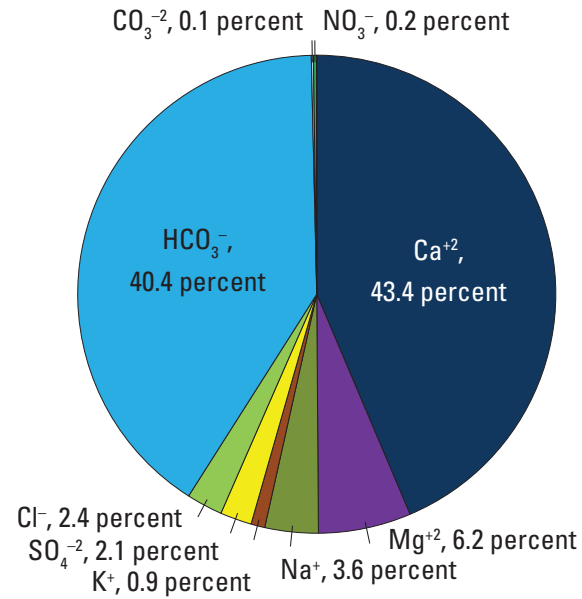

D. WN-295; $\mathrm{SC}=668 ; \mathrm{pH}=9.2$

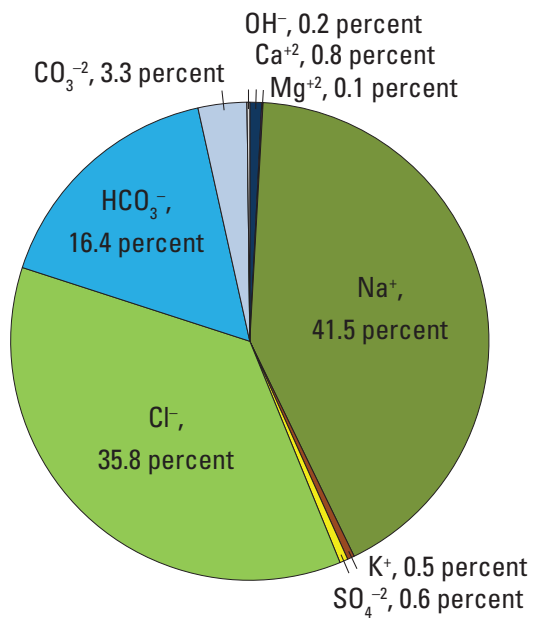

\section{EXPLANATION}

\begin{tabular}{|l|l|}
\hline Hydrogen $\left(\mathrm{H}^{+}\right)$ & Chloride $\left(\mathrm{Cl}^{-}\right)$ \\
\hline Calcium $\left(\mathrm{Ca}^{+2}\right)$ & Bicarbonate $\left(\mathrm{HCO}_{3}{ }^{-}\right)$ \\
\hline Magnesium $\left(\mathrm{Mg}^{+2}\right)$ & Carbonate $\left(\mathrm{CO}_{3}{ }^{-2}\right)$ \\
\hline Sodium $\left(\mathrm{Na}^{+}\right)$ & Nitrate $\left(\mathrm{NO}_{3}{ }^{-}\right)$ \\
\hline Potassium $\left(\mathrm{K}^{+}\right)$ & $\quad$ Hydroxide $\left(\mathrm{OH}^{-}\right)$ \\
\hline Sulfate $\left(\mathrm{SO}_{4}{ }^{-2}\right)$ & \\
\hline
\end{tabular}

SC, specific conductane, in milligrams per liter at 25 degrees Celsius

Figure 24. Typical ionic contributions to computed specific conductance (SC) for selected groundwater samples from Wayne County, 2014, for wells $A, \mathrm{WN}-345, B, \mathrm{WN}-371, C, \mathrm{WN}-361$, and $D, \mathrm{WN}-295$. Individual ion conductivities estimated from dissolved constituent concentrations using methods of McCleskey and others (2012) after aqueous speciation calculations with PHREEOC (Parkhurst and Appelo, 2013). Note that the ionic conductivity contributions for samples having relatively low SC values (WN-371 and WN-345) are dominated by calcium $\left(\mathrm{Ca}^{2+}\right)$, magnesium $\left(\mathrm{Mg}^{2+}\right)$, bic arbonate $\left(\mathrm{HCO}_{3}{ }^{-}\right)$, and sulfate $\left(\mathrm{SO}_{4}{ }^{2-}\right)$. In contrast, the samples with higher $\mathrm{SC}$ values have increased contributions from sodium $\left(\mathrm{Na}^{+}\right)$and chloride $(\mathrm{Cl})$. 


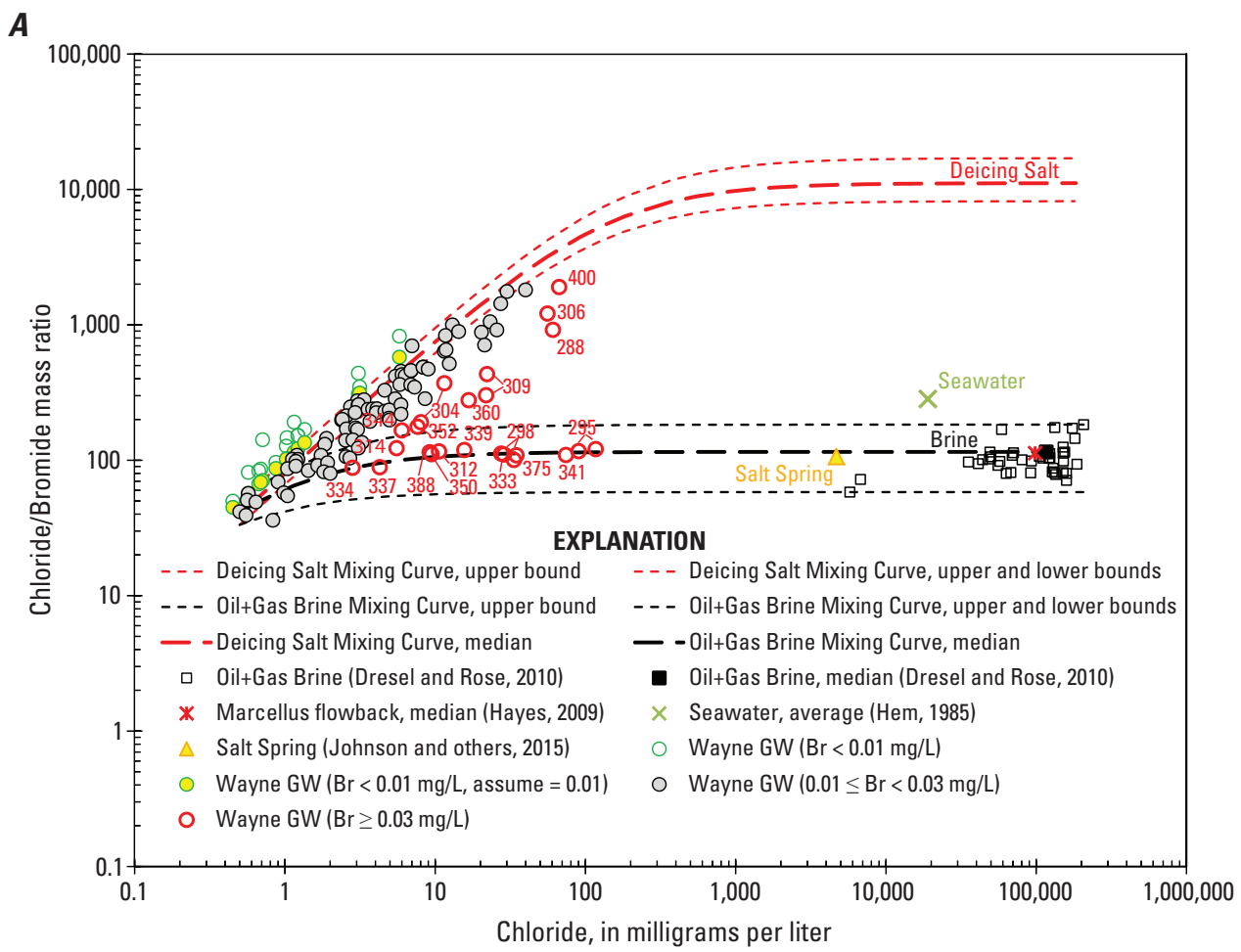

B

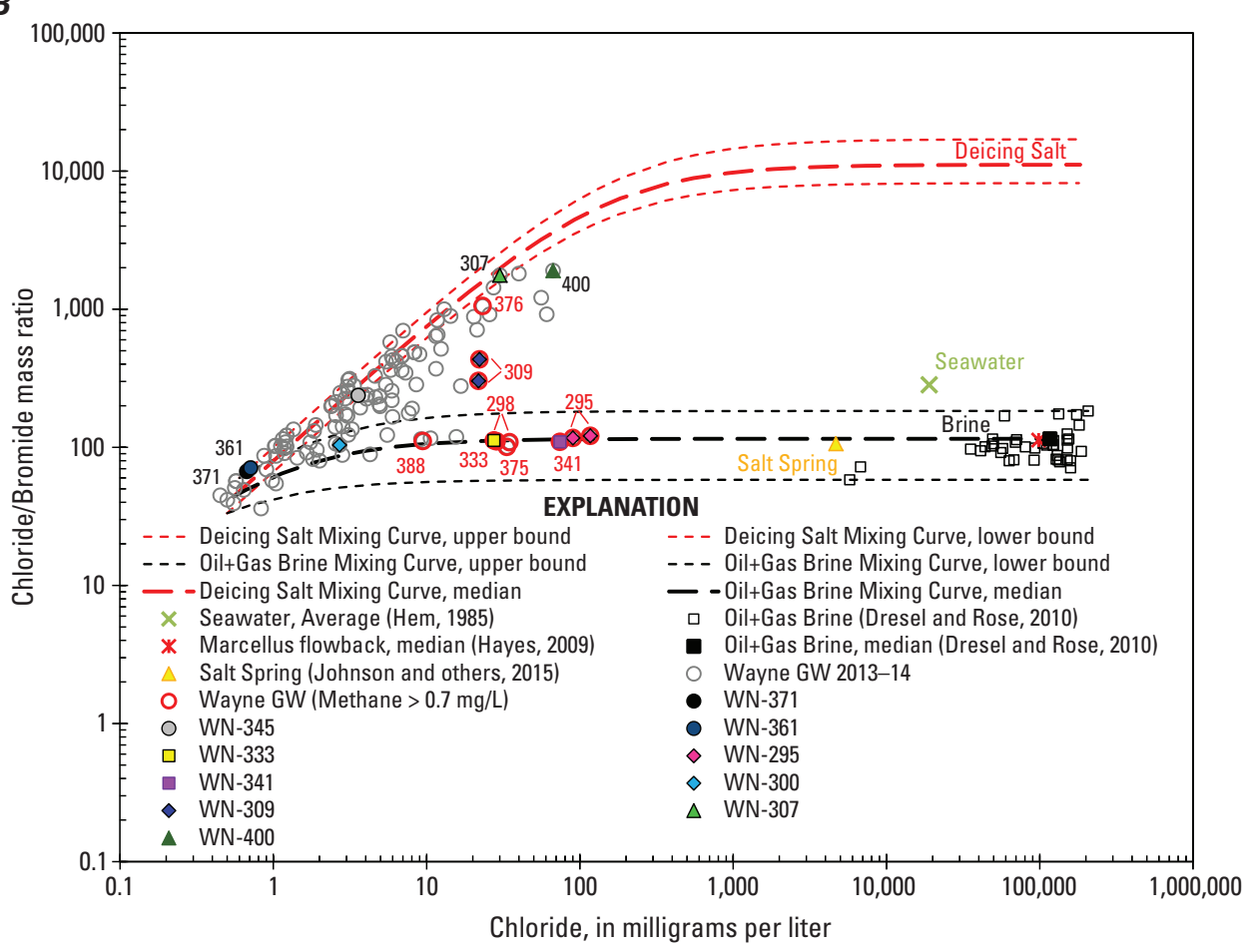

Figure 25. Chloride concentrations in relation to $A$, chloride/bromide mass ratios for various ranges of bromide concentrations, $B$, chloride/bromide mass ratios for samples with and without elevated $(>1.0 \mathrm{mg} / \mathrm{L}$ ) methane concentrations, $C$, bromide concentrations, and $D$, sodium concentrations for 121 groundwater samples collected from 117 wells in Wayne County, Pennsylvania, 2013-14, plus median values for Salt Spring, flowback waters from Marcellus Shale gas wells, and oil- and gas-field brines from Western Pennsylvania. Mixing curves computed for initial fresh water with chloride concentration (Cl) of 0.5 to 0.6 milligrams per liter and bromide concentration (Br) of 0.01 to $0.015 \mathrm{mg} / \mathrm{L}$ mixed with road deicing salt having composition $\mathrm{NaCl}_{0.99996} \mathrm{Br}_{0.00004}$ or with median composition of oil- and gas-field brine. [Salt spring values from Llewellyn (2014). Flowback water values from Marcellus Shale gas wells from Hayes (2009). Oil- and gas-field brine values from Dresel and Rose (2010). Road salt composition from Llewellyn (2014). (GW, groundwater)] 

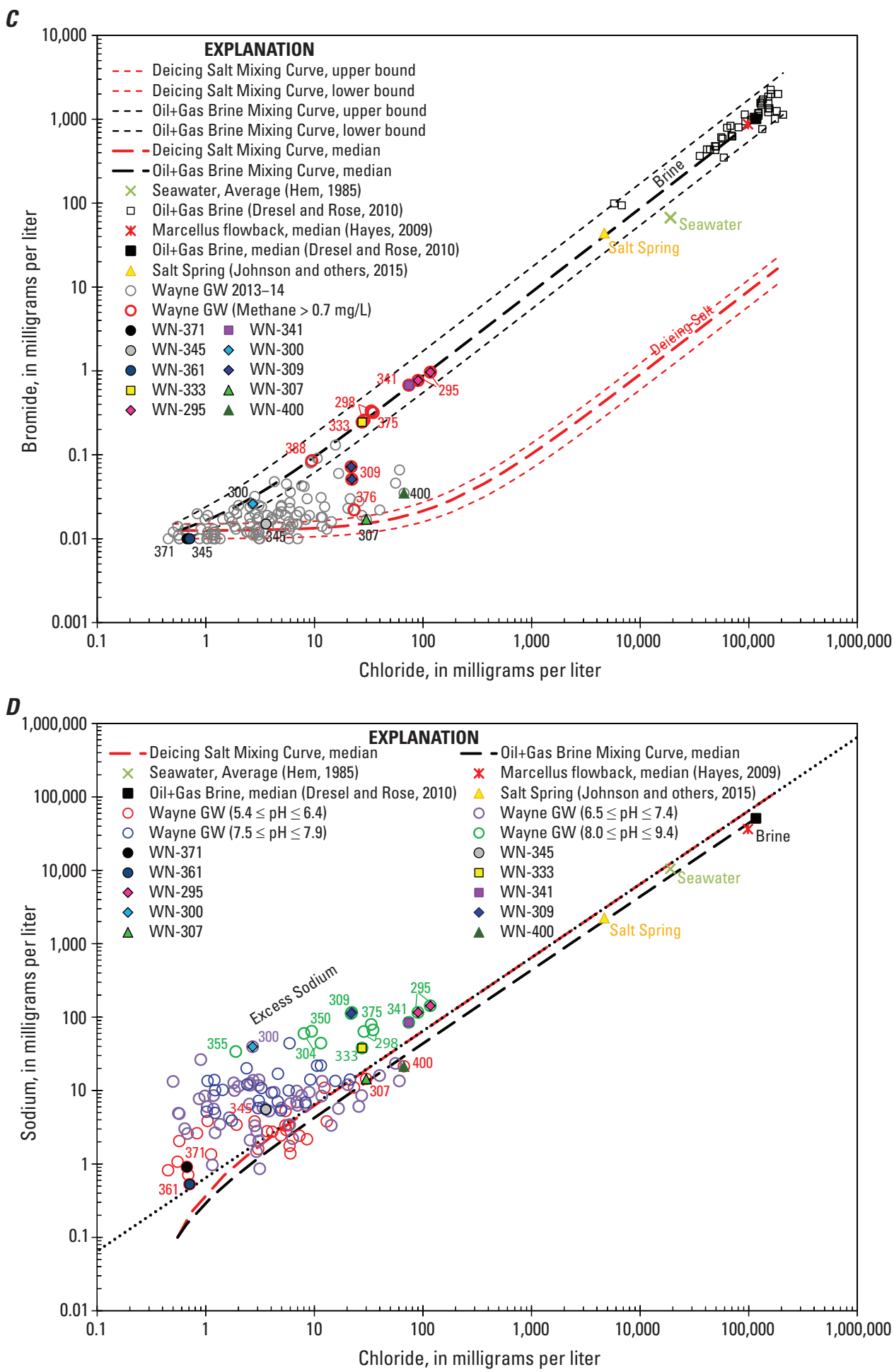

Figure 25. Chloride concentrations in relation to $A$, chloride/bromide mass ratios for various ranges of bromide concentrations, $B$, chloride/bromide mass ratios for samples with and without elevated $(>1.0 \mathrm{mg} / \mathrm{L})$ methane concentrations, $C$, bromide concentrations, and $D$, sodium concentrations for 121 groundwater samples collected from 117 wells in Wayne County, Pennsylvania, 2013-14, plus median values for Salt Spring, flowback waters from Marcellus Shale gas wells, and oil- and gas-field brines from Western Pennsylvania. Mixing curves computed for initial fresh water with chloride concentration ( $\mathrm{Cl}$ ) of 0.5 to 0.6 milligrams per liter and bromide concentration $(\mathrm{Br})$ of 0.01 to $0.015 \mathrm{mg} / \mathrm{L}$ mixed with road deicing salt having composition $\mathrm{NaCl}_{0.99996} \mathrm{Br}_{0.00004}$ or with median composition of oil- and gas-field brine. [Salt spring values from Llewellyn (2014). Flowback water values from Marcellus Shale gas wells from Hayes (2009). Oil- and gas-field brine values from Dresel and Rose (2010). Road salt composition from Llewellyn (2014). (GW, groundwater)]—Continued 
concentration of chloride in groundwater samples show potentially different sources of salinity, including road-deicing salts and brines from oil and gas operations. The chloride/bromide mass ratios for the water samples from 117 wells are shown in relation to chloride concentrations in figure $25 \mathrm{~A}$ and $\mathrm{B}$, which also show curves representing compositions resulting from mixing of different proportions of dilute groundwater with (1) low-bromide salt (such as sodium chloride used for road salt or in septic effluent) or (2) Marcellus-type oil and gas brines. The laboratory reporting level for bromide was $0.010 \mu \mathrm{g} / \mathrm{L}$ for 2013 samples and $0.030 \mu \mathrm{g} / \mathrm{L}$ for 2014 samples, although estimated concentrations from NWQL were available for bromide concentrations less than the reporting level of $0.030 \mu \mathrm{g} / \mathrm{L}$ in the 2014 samples. Because many of the bromide concentrations are less than $0.030 \mu \mathrm{g} / \mathrm{L}$, the chloride/bromide ratios for these 2014 samples were computed using the estimated bromide concentrations (table 11). Chloride/bromide ratios calculated using bromide concentrations greater than the two reporting levels and those estimated by the laboratory to be less than the reporting level are differentiated by symbol type in figure $25 \mathrm{~A}$.

Most of the Wayne County well-water samples plot on or near the curve representing chloride/bromide mass ratios that would result from addition of a low-bromide source of chloride, such sodium chloride in deicing salt (road salt) or septic systems, to the groundwater (fig. 25A). However, several Wayne County well-water samples (with bromide concentrations greater than $0.030 \mathrm{mg} / \mathrm{L}$ ) plot near or on the mixing curve for oil and gas field brines (figs. 25A and C), indicating a possible small contribution of chloride from a brine-like source. As chloride concentrations increase, the chloride/ bromide mass ratios in these groundwater samples appear to stabilize on the brine-mixing curve at values of about 100 to 120 (figs. 25A). Wayne County samples plotting on the brinemixing curve, with chloride concentrations as low as $10 \mathrm{mg} / \mathrm{L}$, have chloride/bromide mass ratios that are similar to those of the brines, indicating a source of chloride that is similarly enriched in bromide.

The eight water samples with methane concentrations greater than $1 \mathrm{mg} / \mathrm{L}$ are among those samples plotting on the brine-mixing curve (fig. 25B). One of these samples was collected from the deepest well $(1,300 \mathrm{ft})$ in the study, WN-309. Also plotting on this curve is Salt Spring (fig. 25A), a naturally occurring saline spring in Susquehanna County. These chloride/bromide relations are similar to those for 20 groundwater samples collected in 2012 in Sullivan County (Sloto, 2013) and 20 groundwater samples collected in 2012 in Pike County (Senior, 2014), where relatively elevated methane concentrations (greater than $1 \mathrm{mg} / \mathrm{L}$ ) also were present in well-water samples that plot on the brine-mixing curve. These findings indicate that groundwater with relatively elevated bromide and methane concentrations is present locally in northeastern Pennsylvania.

Although most of the Wayne County well-water samples have chloride/bromide ratios that plot along the mixing curve for low-bromide salt (sodium chloride, $\mathrm{NaCl}$ ) (fig. 25B), the concentrations of chloride are not balanced by equivalent amounts of sodium (fig. 25D). Many samples contain excess sodium relative to chloride, indicating sources for sodium other than salt. The most likely sources of this excess sodium, as explained in more detail in section "Evolution of Chemical Composition and the Conceptual Hydrogeochemical Model," are residual sodium on cation exchange sites on clay minerals in the aquifer and, to a lesser extent, dissolution of sodiumbearing silicate minerals.

\section{Correlations Among Major and Trace Constituents in Groundwater}

Principal component analysis (PCA) is a statistical technique used to provide insight to hydrochemical processes affecting groundwater chemistry in the study area by indicating intercorrelations among chemical constituents and environmental variables. Four principal components (PCs) explain nearly 73 percent of the variance in the groundwater dataset and consist of loadings (correlations of individual variables to PCs) for 22 commonly detected constituents (table 9). Associations of additional chemical and physical variables excluded from the statistical (PCA) model because of few detections, redundancy, or other reasons are indicated by the Spearman-rank coefficient of correlation of these variables with the principal component scores, listed below the PCA model loading values (table 9). Positive correlations or loadings indicate that as the value of one constituent increases, the value of the correlated constituent also increases; negative correlations and loadings indicate that as the value of one constituent increases, the value of the correlated constituent decreases.

The first principal component, PC1, accounts for most of the variance of the data ( 42 percent) and is labeled Exchange (table 9) because many of the correlated constituents are interpreted to represent weathering and cation exchange processes as groundwater composition evolves. $\mathrm{PC} 1$ has positive loadings of lithium, potassium, sodium, strontium, barium, $\mathrm{pH}$, alkalinity, arsenic, boron, fluoride, silica, and specific conductance, and negative loading of DO (table 9). Some of these relations can be seen in plots of constituents in relation to $\mathrm{pH}$ (figs. 7, 8, 9, 11, and 22; see also Appendix 4). Scores on $\mathrm{PC} 1$ are positively correlated with total dissolved solids (TDS, ROE), molybdenum, antimony, ammonia, uranium, and gross alpha and beta radioactivity, and negatively correlated with land-surface elevation, zinc, and copper (table 9). The negative associations of $\mathrm{PC} 1$ with land-surface elevation, well-bottom elevation (calculated by subtracting well depth from land-surface elevation), and $\mathrm{DO}$ and positive associations with $\mathrm{pH}$ and TDS are consistent with the conceptual model of older, more evolved groundwater. As recharge passes through the soil zone into underlying fractured rock aquifer, oxygen is consumed, and $\mathrm{pH}$ and TDS increase as groundwater interacts with soil and aquifer materials, oxidizing organic matter and becoming more mineralized, alkaline, and "softened" along 
Table 9. Major factors in principal components analysis model controlling the chemistry of groundwater, Wayne County, Pennsylvania, 2013-14. Analysis included data from 117 wells.

[Varimax rotation pattern for rank-transformed data (SAS, 1988); minimum eigenvalue $>1$; loading values for constituents included in model and Spearman correlation coefficients for constituents excluded from model multiplied by 100 and rounded; *, highly significant loading (p $<0.0001)$; +, significant loading $(\mathrm{p}<0.001) ;<$, less than]

\begin{tabular}{|c|c|c|c|c|c|}
\hline Constituent & $\begin{array}{c}\text { Exchange } \\
\text { PC1 }\end{array}$ & $\begin{array}{c}\text { Redox } \\
\text { PC2 }\end{array}$ & $\begin{array}{c}\text { Hardness } \\
\text { PC3 }\end{array}$ & $\begin{array}{c}\text { Chloride } \\
\text { PC4 }\end{array}$ & Communality \\
\hline \multicolumn{6}{|c|}{ Loadings for constituents included in model (variable name) } \\
\hline Lithium (Li) & $94 *$ & 11 & -4 & 21 & 0.930 \\
\hline Strontium (Sr) & $88^{*}$ & -11 & 23 & 2 & 0.850 \\
\hline Potassium (K) & $87^{*}$ & 1 & 20 & 24 & 0.851 \\
\hline Arsenic (As) & $81^{*}$ & -11 & -14 & 21 & 0.729 \\
\hline Barium (Ba) & $79 *$ & -21 & 14 & 17 & 0.721 \\
\hline Sodium (Na) & $78 *$ & 34 & 1 & 33 & 0.842 \\
\hline $\mathrm{pH}(\mathrm{pH})$ & $78^{*}$ & 30 & 6 & 8 & 0.709 \\
\hline Boron (B) & $78^{*}$ & 22 & -9 & 29 & 0.747 \\
\hline Fluoride (F) & $76^{*}$ & 29 & -12 & -10 & 0.680 \\
\hline Alkalinity (ALK) & $72 *$ & $37+$ & $35+$ & 25 & 0.846 \\
\hline Specific Conductance (SCL) & $68^{*}$ & 24 & $35+$ & $51^{*}$ & 0.899 \\
\hline Silica (SiO2) & $59 *$ & -11 & $38+$ & -1 & 0.507 \\
\hline Iron $(\mathrm{Fe})$ & -5 & $83^{*}$ & -12 & 7 & 0.710 \\
\hline Manganese (Mn) & 7 & $70^{*}$ & -34 & 20 & 0.645 \\
\hline Nitrate (NO3N) & -21 & $-59^{*}$ & 31 & $43+$ & 0.673 \\
\hline Dissolved Oxygen (DOX) & $-58^{*}$ & $-62 *$ & -12 & -4 & 0.731 \\
\hline Calcium $(\mathrm{Ca})$ & 18 & -22 & $88^{*}$ & 15 & 0.874 \\
\hline Magnesium (Mg) & 24 & 2 & $82 *$ & -9 & 0.744 \\
\hline Sulfate (SO4) & 8 & $38+$ & $44^{*}$ & $40+$ & 0.496 \\
\hline Aluminum (Al) & 18 & 28 & $-58^{*}$ & 19 & 0.480 \\
\hline Chloride (Cl) & 28 & -2 & -6 & $85^{*}$ & 0.805 \\
\hline Bromide (Br) & 30 & 20 & -12 & $76^{*}$ & 0.713 \\
\hline Eigenvalue & 9.378 & 3.681 & 1.784 & 1.339 & 16.182 \\
\hline Cumulative Percent Variance Explained & 42.63 & 59.36 & 67.47 & 73.56 & \\
\hline
\end{tabular}

flow paths from recharge areas in uplands to discharge areas in valleys. High positive scores on PC1 (> 50, table 9) generally may be attributed to the progressive weathering of calcite and dolomite (carbonate minerals) and silicate minerals (sources of silica) combined with cation-exchange processes (Hem, 1985). Cation exchange reactions, which liberate sodium and other alkali metals, such as lithium and potassium, while removing alkaline earth metals calcium and magnesium (hardness), generally take place where sodium (and other alkali metals) is retained by clay minerals in the siliciclastic bedrock along flow paths (discussed in the section "Evolution of Chemical Composition and the Conceptual Hydrogeochemical Model").

Although barium and strontium have positive loadings on the $\mathrm{PC} 1$ factor, measured concentrations of these constituents peak around $\mathrm{pH} 7.5$ to 8.5 , then decline with increasing $\mathrm{pH}$ above 8.5 (fig. $22 \mathrm{C}$ ), indicating that barium and strontium (alkaline earth metals like calcium) may also be removed from solution through the ion exchange process and may not be conservative tracers for brines. Barium and strontium are present in high concentrations in brines. The mass ratio of barium and strontium in relation to magnesium $[(\mathrm{Ba}+\mathrm{Sr}) / \mathrm{Mg}$ mass ratio] has been used to identify sources of regional brine and road salt in northern Susquehanna County and vicinity, with increasing values above background freshwater of about 0.02 to 0.04 , indicating contributions of brine to groundwater and streams (Johnson and others, 2015). In the Wayne County groundwater samples, the $(\mathrm{Ba}+\mathrm{Sr}) / \mathrm{Mg}$ mass ratio generally increases with $\mathrm{pH}$ from values near 0.01 at acidic $\mathrm{pH}$ to values 
Table 9. Major factors in principal components analysis model controlling the chemistry of groundwater, Wayne County, Pennsylvania, 2013-14. Analysis included data from 117 wells.-Continued

[Varimax rotation pattern for rank-transformed data (SAS, 1988); minimum eigenvalue $>1$; loading values for constituents included in model and Spearman correlation coefficients for constituents excluded from model multiplied by 100 and rounded; *, highly significant loading (p $<0.0001$ ); +, significant loading $(\mathrm{p}<0.001) ;<$, less than]

\begin{tabular}{|c|c|c|c|c|c|}
\hline Constituent & $\begin{array}{l}\text { Exchange } \\
\text { PC1 }\end{array}$ & $\begin{array}{l}\text { Redox } \\
\text { PC2 }\end{array}$ & $\begin{array}{l}\text { Hardness } \\
\text { PC3 }\end{array}$ & $\begin{array}{l}\text { Chloride } \\
\text { PC4 }\end{array}$ & Communality \\
\hline \multicolumn{6}{|c|}{ Significant Spearman correlations for constituents not included in model (variable name) $(p<0.001)$} \\
\hline Total Dissolved Solids (TDS) & 70 & & 38 & 45 & \\
\hline Residue on Evaporation 180C (ROE180) & 66 & & 37 & 50 & \\
\hline $\begin{array}{l}\text { Gross beta radioactivity, } 72 \text {-hour count, water, filtered, } \\
\text { Cs-137 curve, picocuries per liter (BetaCs72) }\end{array}$ & 51 & & & & \\
\hline Antimony (Sb) & 44 & & & & \\
\hline Well Bottom Elevation (WELLZALT) & -67 & & & & \\
\hline Methane (Methane) & & 35 & & & \\
\hline Selenium (Se) & & -39 & & & \\
\hline Copper $(\mathrm{Cu})$ & -40 & -42 & & & \\
\hline Lead $(\mathrm{Pb})$ & & -47 & & & \\
\hline Nitrogen, Total (NT) & & -59 & & 43 & \\
\hline Hardness (Hard) & & & 92 & & \\
\hline Cobalt (Co) & & & & 38 & \\
\hline
\end{tabular}

near 1.0 at $\mathrm{pH}$ of 8 and greater, with some exceptions that may be related to local aquifer mineralogy; some of the relative increase in barium and magnesium with $\mathrm{pH}$ may be related to dissolution of barium- and strontium-bearing minerals, and possibly small contributions of saline water.

With the addition of sodium and the removal of calcium and magnesium from solution, the groundwater can become undersaturated with respect to calcite and dolomite, thus promoting additional dissolution of the carbonate minerals and progressive increases in $\mathrm{pH}$ and alkalinity. The resultant sodium-bicarbonate waters have alkaline (basic) $\mathrm{pH}$ values and high positive scores on $\mathrm{PC} 1$. At elevated $\mathrm{pH}(>8)$, silica solubility increases and various trace elements that occur as oxyanions in groundwater, including arsenic, boron, molybdenum, antimony, and uranium (complexed with carbonate ions), tend to be poorly sorbed; however, at $\mathrm{pH}$ greater than 8 , trace cations, such as copper and zinc, tend to be adsorbed from solution.
PC2 is labeled Redox (table 5) because positive loading and positively correlated constituents are interpreted to indicate reducing conditions, and negative loadings and negatively correlated constituents indicate oxidizing conditions. PC2, which explains 16.8 percent of the variance in the data, has positive loadings of iron, manganese, and alkalinity and negative loadings by DO, nitrate, and sulfate (table 9). Scores on PC2 are positively correlated with ammonia and methane and negatively correlated with copper, lead, selenium, and total nitrogen. The samples that had positive scores for PC2 were classified as anoxic (DO less than or equal to $0.5 \mathrm{mg} / \mathrm{L}$ ). Methane is stable in anoxic groundwater and may be relatively stable in very low oxygen groundwater, such as that observed in many of the Wayne County well-water samples; the highest concentrations of methane were measured in groundwater samples with very low oxygen concentrations (less than or equal to $0.5 \mathrm{mg} / \mathrm{L}$ ). High positive scores on PC2 are interpreted to indicate isolation from the atmosphere, the 
development of reducing conditions, and the production of alkalinity without strong effects from carbonate dissolution (implied by $\mathrm{PC} 1$ and $\mathrm{PC} 3$ ) or ion exchange (implied by PC1). Alkalinity $\left(\mathrm{HCO}_{3}^{-}\right)$indicated by $\mathrm{PC} 2$ can be produced without affecting major cation concentrations by the reductive dissolution of $\mathrm{Fe}^{\mathrm{III}}$-oxides $(\mathrm{FeOOH}), \mathrm{Mn}^{\mathrm{III}-\mathrm{IV}}$-oxides $\left(\mathrm{MnO}_{2}\right)$, nitrate $\left(\mathrm{NO}_{3}^{-}\right)$, or sulfate $\left(\mathrm{SO}_{4}^{2-}\right)$ in reactions involving organic carbon (represented as $\mathrm{CH}_{2} \mathrm{O}$ in $4 \mathrm{FeOOH}+\mathrm{CH}_{2} \mathrm{O}+7 \mathrm{H}^{+}=4 \mathrm{Fe}^{2+}+$ $\mathrm{HCO}_{3}^{-}+6 \mathrm{H}_{2} \mathrm{O} ; 2 \mathrm{MnO}_{2}+\mathrm{CH}_{2} \mathrm{O}+3 \mathrm{H}^{+}=2 \mathrm{Mn}^{2+}+\mathrm{HCO}_{3}^{-}+$ $2 \mathrm{H}_{2} \mathrm{O} ; 4 \mathrm{NO}_{3}^{-}+5 \mathrm{CH}_{2} \mathrm{O}=2 \mathrm{~N}_{2}+4 \mathrm{HCO}_{3}^{-}+\mathrm{H}_{2} \mathrm{CO}_{3}+2 \mathrm{H}_{2} \mathrm{O}$; and $\left.\mathrm{SO}_{4}^{2-}+2 \mathrm{CH}_{2} \mathrm{O}=\mathrm{H}_{2} \mathrm{~S}+2 \mathrm{HCO}_{3}^{-}\right)$, thereby increasing concentrations of dissolved iron $\left(\mathrm{Fe}^{2+}\right)$ and manganese $\left(\mathrm{Mn}^{2+}\right)$ and decreasing concentrations of sulfate and nitrate. The general pattern of higher concentrations of dissolved iron and manganese associated with lower concentrations of nitrate and sulfate was observed in the Wayne County groundwater samples (fig. 13). However, although 20 percent of the samples were anoxic (DO $\leq 0.5 \mathrm{mg} / \mathrm{L})$, few had chemical characteristics consistent with $\mathrm{Mn}^{\mathrm{IV}}$ and $\mathrm{Fe}^{\mathrm{IIII}}$ reducing conditions (dissolved concentrations of $\mathrm{NO}_{3}<0.5 \mathrm{mg} / \mathrm{L}, \mathrm{Mn}>0.05 \mathrm{mg} / \mathrm{L}$, $\mathrm{Fe}>0.1 \mathrm{mg} / \mathrm{L}$, and $\mathrm{SO}_{4}>0.5 \mathrm{mg} / \mathrm{L}$ ), as defined by McMahon and Chapelle (2008) or the more strongly reducing conditions necessary for sulfate reduction only or for methanogenesis $\left(\mathrm{SO}_{4}<0.5 \mathrm{mg} / \mathrm{L}\right)$. The negative correlations of lead and copper with PC2 could indicate decreased mobility of these constituents where the concentrations of dissolved iron, manganese, and alkalinity are elevated, possibly because of coprecipitation with siderite $\left(\mathrm{FeCO}_{3}\right)$ or because most anoxic waters had alkaline $\mathrm{pH}$ that limits solubility of lead and copper.

PC3 is labeled Hardness (table 9) because positive loadings and correlations are interpreted to indicate processes that increase hardness in groundwater. PC3, which explains 8.2 percent of the variance in the data, has positive loadings by calcium, magnesium, sulfate, alkalinity, silica, and specific conductance and negative loadings by aluminum (table 9). Scores on PC3 are positively correlated with hardness, dissolved solids, and uranium. High positive scores on PC3 can be attributed to the dissolution of calcite, dolomite, gypsum, and possibly pyrite or other sulfide minerals without the cation-exchange softening effects (alkaline $\mathrm{pH}$ ) indicated by high scores on PC1. The negative loading of aluminum on PC3 is consistent with its solubility minimum exerted by oxide and aluminosilicate minerals at slightly acidic to near-neutral $\mathrm{pH}$ (5.5 to 7.0). The positive correlation with uranium is consistent with its mobilization as the uranyl-carbonate complex, whereas positive association of sulfate implies intermediate redox conditions. Uranium mineralization at some locations in the Catskill Formation in northeastern Pennsylvania is associated with copper and iron sulfides (Klemic, 1962), potentially providing sources of sulfate where uranium is present.

PC4, which explains 6.0 percent of the variance in the data, has positive loadings by chloride, bromide, nitrate, sulfate, and specific conductance, and is labeled Chloride (table 5) because positive loadings and correlations provide information about various sources of chloride. Scores on PC4 are positively correlated with TDS, total nitrogen, and cobalt.
The strong positive association between chloride and bromide indicates the possible contribution of Appalachian Basin brine to the groundwater of associated samples. However, the additional correlations with nitrate and sulfate indicate possible man-made sources of contamination, such as sewage, fertilizer, or road-deicing salt. The relations between chloride and other constituents associated with PC4 indicate that chloride appears to be from multiple sources (high-bromide brine source and low-bromide man-made sources), as discussed in section "Ratios of Chloride, Bromide, and Sodium in Groundwater" and shown on the chloride/bromide ratio plots (figs. 25A-C).

\section{Evolution of Chemical Composition and the Conceptual Hydrogeochemical Model}

The observed water types and relations among selected constituents and $\mathrm{pH}$ indicate that dilute recharge waters interact with minerals in the near surface, gradually becoming less acidic and less oxygenated, while increasing in concentrations of dissolved constituents. The predominant processes that account for the observed chemical composition of waters were modeled using the progressive dissolution of calcite (calcium carbonate) to equilibrium, combined in some cases with cation exchange and mixing with saline or brine-like waters. Evaluation of the Wayne County groundwater-quality data indicates that calcite is undersaturated (can dissolve) in waters with $\mathrm{pH}$ less than about 7.5 to 8 but nears saturation in waters with $\mathrm{pH}$ greater than about 8 . Detailed descriptions of geochemical modeling and evaluation of the potential for minerals to dissolve or precipitate (saturation indices) in Wayne County groundwaters are provided in the following section.

\section{Geochemical Modeling}

The Catskill Formation consists of clastic sedimentary bedrock that includes shale, siltstone, sandstone, arkose, and conglomerate (Sloto, 2014). Such clastic rocks are mainly composed of silicate and aluminosilicate minerals, including quartz, feldspar, chlorite, muscovite, and illite, plus minor carbonate, sulfate, sulfide, and oxide minerals that occur as clasts, fracture filling, and cements. Although mineralogy is expected to vary locally, the carbonate, sulfate, and sulfide minerals are prone to weathering in near-surface environments where they may be important sources of hardness, acid neutralizing capacity (ANC) or alkalinity, $\mathrm{SO}_{4}$, and other solutes. Likewise, various clay minerals, which are hydrated aluminosilicates having layered crystal structures that readily accommodate ionic substitutions, are widely recognized to be involved in cation-exchange and sorption processes (Hem, 1985; Appelo and Postma, 2005). For example, reactions involving chlorite, muscovite, illite, and kaolinite, which are common clay minerals in soils, shales, and siltstones, could affect solute concentrations in well-water samples from the study area. 
To evaluate the potential for various minerals to be dissolved or precipitated by the groundwater, the saturation index (SI) values are displayed as a function of $\mathrm{pH}$ for the Wayne County well-water samples in figure 26 . The samples that had $\mathrm{pH}$ less than or equal to 8 were undersaturated (SI less than 0 ) with respect to calcite and dolomite $\left(\mathrm{CaMg}\left(\mathrm{CO}_{3}\right)_{2}\right)$, indicating the groundwater could feasibly dissolve these carbonate minerals, if present. The SI for calcite increased linearly from $\mathrm{pH}$ of 5.4 (SI -4.14) to $\mathrm{pH}$ of 8 (SI -0.2), above which the SI value approximately equal to 0 was maintained. Despite the indicated equilibrium, dissolution of calcite could be anticipated to continue at $\mathrm{pH}$ values greater than 8 because of the removal of calcium $(\mathrm{Ca})$ in exchange of sodium $(\mathrm{Na})$. As the concentrations of $\mathrm{Ca}$ are depleted, the groundwater could dissolve more calcite with progressive increases in concentrations of ANC and $\mathrm{pH}$ to values as high as 9.3 (fig. 26).

On the basis of negative SI values, feldspar minerals, represented by albite $\left(\mathrm{NaAlSi}_{3} \mathrm{O}_{8}\right)$ were undersaturated and could feasibly dissolve in groundwater, albeit slowly. In addition to being sources of base cations [Na, potassium (K), $\mathrm{Ca}$ ], aluminum ( $\mathrm{Al})$, and silicon $(\mathrm{Si})$, the feldspars commonly contain traces of phosphate $\left(\mathrm{PO}_{4}\right)$ and, thus, could be a potential natural source of $\mathrm{PO}_{4}$ in the sampled groundwaters (Denver and others, 2010). Likewise, the clay mineral chlorite $\left.\left(\mathrm{Mg}_{5} \mathrm{Al}_{2} \mathrm{Si}_{3} \mathrm{O}_{10}(\mathrm{OH})_{8}\right)\right)$ was indicated to be undersaturated and unstable. In contrast, quartz $\left(\mathrm{SiO}_{2}\right)$ and kaolinite $\left(\mathrm{Al}_{2} \mathrm{Si}_{2} \mathrm{O}_{5}(\mathrm{OH})_{4}\right)$ were saturated or supersaturated. Thus, over the range of $\mathrm{pH}$ for the samples in this study, the unstable aluminosilicates generally would be anticipated to dissolve incongruently, releasing cations to solution while $\mathrm{Si}$ and $\mathrm{Al}$ are retained in secondary solid phases, such as quartz and kaolinite. Other clay minerals, including beidellite $\left(\left(\mathrm{NaKMg}_{0.5}\right)_{0.11}\right.$ $\left.\mathrm{Al}_{2.33} \mathrm{Si}_{3.67} \mathrm{O}_{10}(\mathrm{OH})_{2}\right)$ ), illite $\left.\left(\mathrm{K}_{0.6} \mathrm{Mg}_{0.25} \mathrm{Al}_{2.3} \mathrm{Si}_{3.5} \mathrm{O}_{10}(\mathrm{OH})_{2}\right)\right)$, and muscovite $\left(\mathrm{KAl}_{3} \mathrm{Si}_{3} \mathrm{O}_{10}(\mathrm{OH})_{2}\right)$, had SI values that ranged from negative to positive, indicating these or similar phases could potentially decompose where undersaturated, or such phases could participate in surface complexation or exchange reactions where saturated or supersaturated.

The major $\mathrm{Ca}$ and magnesium $(\mathrm{Mg})$ carbonate minerals commonly contain traces of other cations, including iron $(\mathrm{Fe})$, manganese (Mn), strontium ( $\mathrm{Sr}$ ), and barium $(\mathrm{Ba})$ (Hanshaw and Back, 1979). These trace cations also could be present locally as pure carbonate phases. Over the range of $\mathrm{pH}$, the SI values for siderite $\left(\mathrm{FeCO}_{3}\right)$, rhodochrosite $\left(\mathrm{MnCO}_{3}\right)$, strontianite $\left(\mathrm{SrCO}_{3}\right)$, and witherite $\left(\mathrm{BaCO}_{3}\right)$ were negative, indicating these carbonate minerals, if present, could feasibly be dissolved by the groundwater. Hence, dissolution of calcite, dolomite, or other carbonates could release various trace cations to solution. However, the concentrations of trace elements may be limited by the formation of other solid phases. For example, the accumulation of $\mathrm{SO}_{4}$ from rainfall, sulfide mineral oxidation, or gypsum $\left(\mathrm{CaSO}_{4} \cdot 2 \mathrm{H}_{2} \mathrm{O}\right)$ dissolution could promote the observed supersaturation of barite $\left(\mathrm{BaSO}_{4}\right)$, which could precipitate and limit the concentrations of dissolved $\mathrm{Ba}$. In contrast, celestine $\left(\mathrm{SrSO}_{4}\right)$ was indicated to be undersaturated.
Nevertheless, Sr concentrations could possibly be limited by coprecipitation with Ba in barite (Hanor, 1968). Furthermore, $\mathrm{Sr}, \mathrm{Ba}$, and other trace cations could participate in exchange reactions with clay minerals or adsorption processes.

Hydrous oxides of iron $\left(\mathrm{FeOOH}, \mathrm{Fe}(\mathrm{OH})_{3}(\mathrm{a})\right)$ and manganese $(\mathrm{MnOOH})$ are common in soils and weathered bedrock. The groundwaters sampled for the study generally were indicated to be saturated or supersaturated with respect to $\mathrm{Fe}$ and $\mathrm{Mn}$ oxides, which indicates such phases could feasibly precipitate as stable secondary phases (although the redox state is uncertain) upon dissolution of carbonates or oxidation of sulfides containing Fe and Mn. The hydrous Fe and Mn oxides are widely recognized as potential sorbents of trace anions (As, Se, Mo, B) at acidic $\mathrm{pH}$ and cations $(\mathrm{Cu}, \mathrm{Pb}, \mathrm{Zn})$ at neutral to alkaline pH (Appelo and Postma, 2005; Dzombak and Morel, 1990; Hem 1985). Adsorption, or surface complexation, can maintain trace-element concentrations at low levels compared to the solubilities of corresponding trace-element minerals; however, as the $\mathrm{pH}$ or redox conditions change, the trace ions could be released into solution by the oxides (Chapman and others, 2013). An illustration of the effects of changes in $\mathrm{pH}$ on the potential for adsorption and desorption of trace elements by hydrous Fe oxide are shown in figure 27.

The evolution pathways for the major ions indicated on the Piper diagram (fig. 23D) and as mixing curves on the bromide/chloride and sodium/chloride plots (fig. 25) were computed using the PHREEQC geochemical model, considering the various mixing scenarios with road deicing salt or brine plus reactions including calcite dissolution and (or) cation exchange. In addition to determining the concentrations of major cations and bromide, displayed previously, the geochemical models also indicated the effects of reactions and mixtures on the $\mathrm{pH}$ and the concentrations of minor elements including strontium, barium, potassium, and lithium.

Parallel sets of reaction models initially simulated the addition of road deicing salt or brine to groundwater, without or with calcite dissolution, but did not consider cation exchange (fig. 28). The simplest models indicated the effect of increasing additions of the specified salt (fig. 28A) or brine (fig. 28C) to the initial groundwater. For both scenarios, the $\mathrm{pH}$ decreased progressively from the initial value of 6.2, whereas the concentrations of sodium, chloride, and bromide increased. Because the samples that had elevated sodium (34 to $143 \mathrm{mg} / \mathrm{L}$ ) (figs. 22 and 25D) had alkaline $\mathrm{pH}$, these conservative mixing models were considered unsatisfactory and were enhanced by specifying that calcite would dissolve to equilibrium (fig. 28B and D). The resultant models that involved mixing and calcite dissolution produced results that could explain the formation of near-neutral waters of calciumsodium/bicarbonate-chloride types, such as samples from WN-307 or WN-400, but not the sodium/bicarbonate types with $\mathrm{pH}$ values greater than 8 .

The geochemical models were modified further to evaluate the potential effects of calcite dissolution plus cation exchange on the $\mathrm{pH}$ and solute concentrations (fig. 29). For 


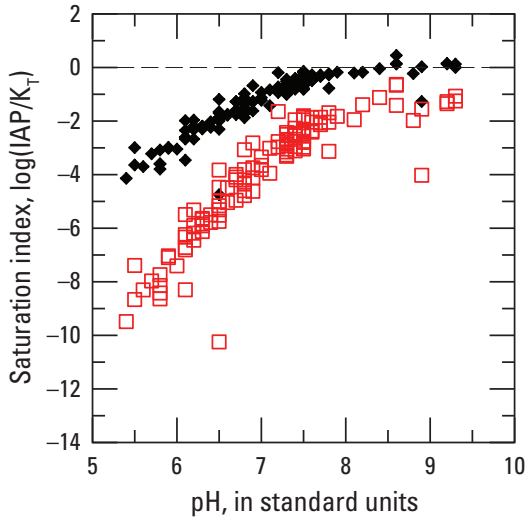

EXPLANATION

- Calcite- $\mathrm{CaCO}_{3}$

$\square$ Dolomite- $\mathrm{CaMg}\left(\mathrm{CO}_{3}\right)_{2}$

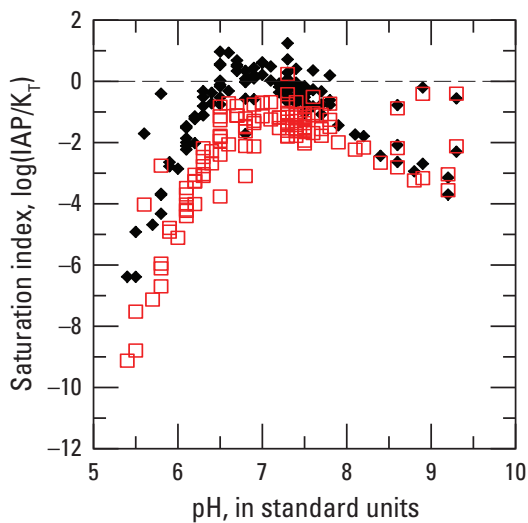

EXPLANATION

- Beidellite- $\left(\mathrm{NaKMg}_{0.5}\right)_{0.11} \mathrm{Al}_{2.33} \mathrm{Si}_{3.67} \mathrm{O}_{10}(\mathrm{OH})_{2}$

口 Illite $-\mathrm{K}_{0.6} \mathrm{Mg}_{0.25} \mathrm{Al}_{2.3} \mathrm{Si}_{3.5} \mathrm{O}_{10}(\mathrm{OH})_{2}$

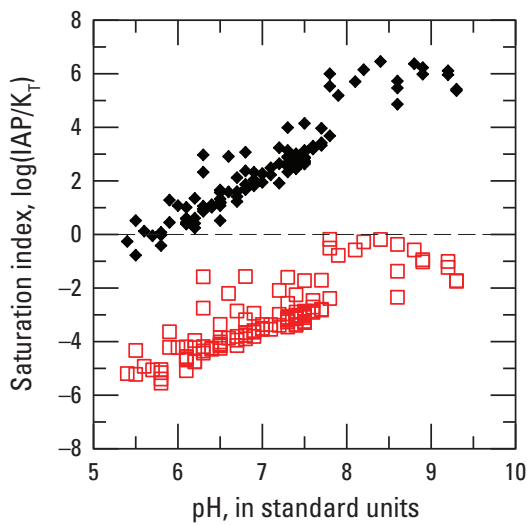

EXPLANATION

- Manganite-MnOOH

$\square$ Rhodochrosite- $\mathrm{MnCO}_{3}$

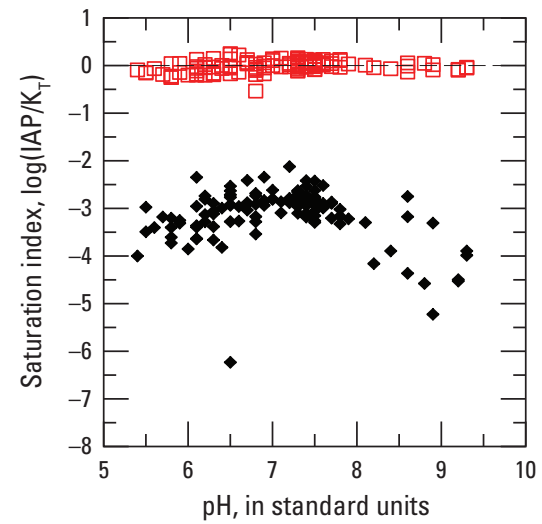

EXPLANATION

- Gypsum- $-\mathrm{CaSO}_{4} \cdot 2 \mathrm{H}_{2} \mathrm{O}$

$\square \quad$ Quartz-SiO

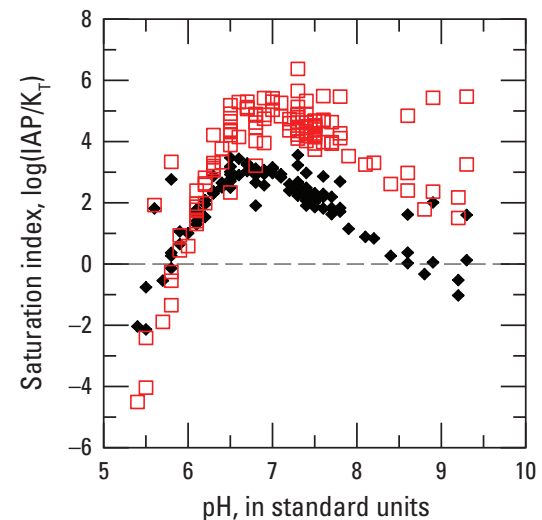

EXPLANATION

- Kaolinite- $\mathrm{Al}_{2} \mathrm{Si}_{2} \mathrm{O5}(\mathrm{OH})_{4}$

$\square$ Muscovite- $-\mathrm{KAI}_{3} \mathrm{Si}_{3} \mathrm{O}_{10}(\mathrm{OH})_{2}$

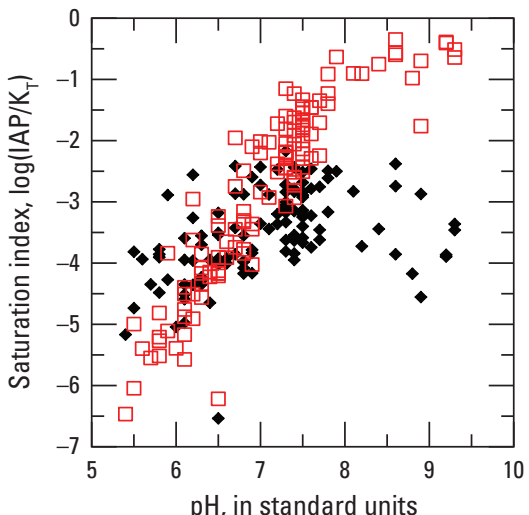

EXPLANATION

- Celestine-SrSO

$\square$ Strontianite- $\mathrm{SrCO}_{3}$

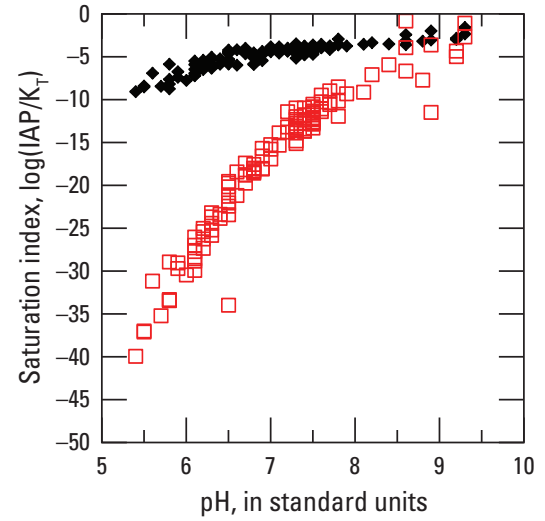

EXPLANATION

- Albite- $\mathrm{NaAlSi}_{3} \mathrm{O}$

$\square$ Chlorite- $\mathrm{Mg}_{5} \mathrm{Al}_{2} \mathrm{Si}_{3} \mathrm{O}_{10}(\mathrm{OH})_{8}$

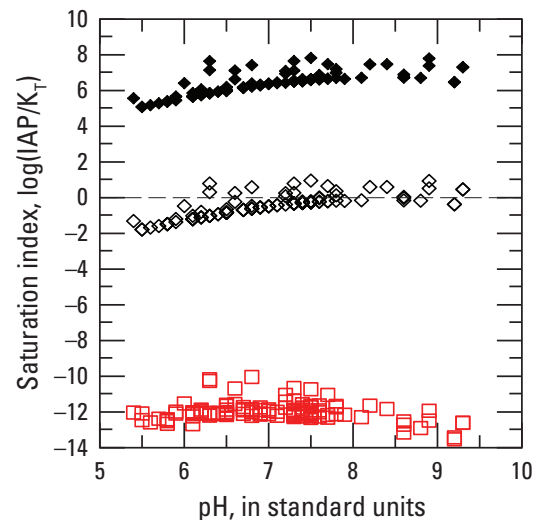

EXPLANATION

- Goethite-Fe0OH

$\diamond \mathrm{Fe}(\mathrm{OH})_{3}(\mathrm{a})-\mathrm{Fe}(\mathrm{OH})_{3}$

$\square$ Siderite- $\mathrm{FeCO}_{3}$

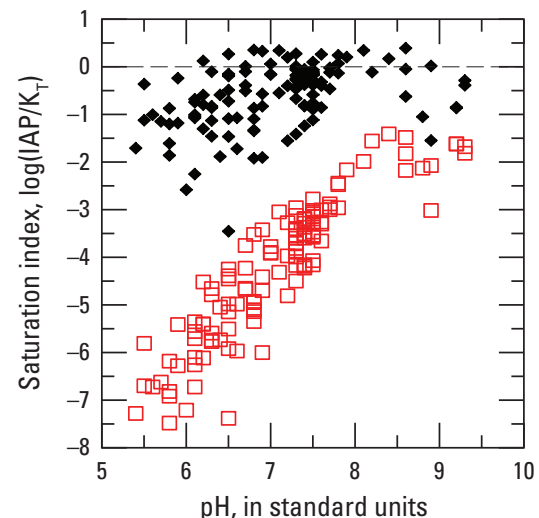

EXPLANATION

- Barite-BaSO

$\square$ Witherite- $-\mathrm{BaCO}_{3}$

Figure 26. Saturation indices for minerals and other solids in relation to $\mathrm{pH}$ for 121 groundwater samples from 117 wells in Wayne County, Pennsylvania, 2013-14. Computations made using PHREEOC (Parkhurst and Appelo, 2013) with WATEQ4F database (Ball and Nordstrom, 1991). [IAP, ion activity product; KT, solubility product (thermodynamic reaction constant)] 

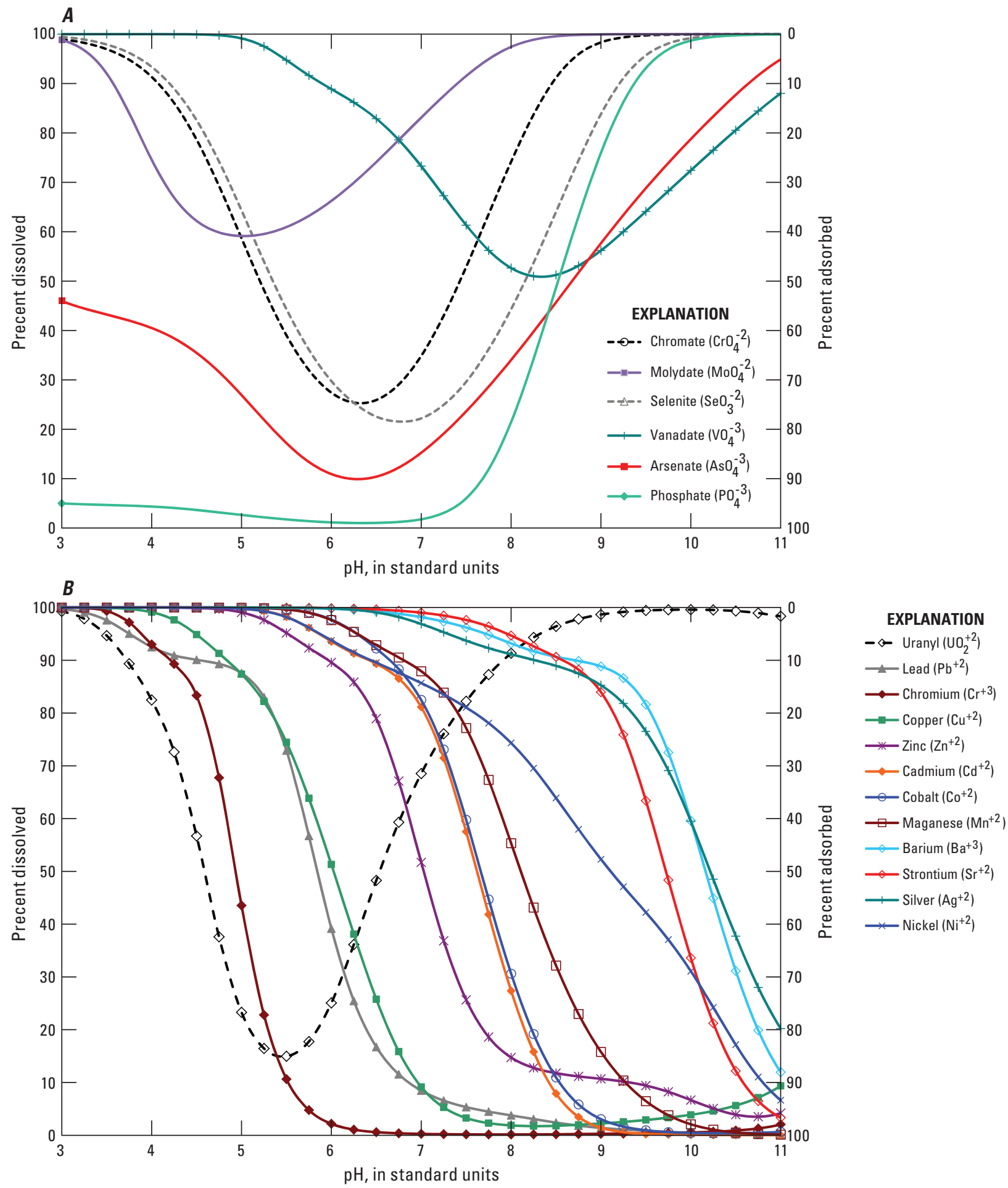

Figure 27. Equilibrium fractions of initial concentrations of $A$, anions or $B$, cations that may be dissolved or adsorbed on a finite amount of hydrous ferric oxide (HFO) at 25 degrees Celsius as a function of $\mathrm{pH}$. Area below curve indicates fraction that is not adsorbed; area above curve indicates fraction that is adsorbed. (From Cravotta and Brady, 2015) 
A

Groundwater + deicing salt;

no cation exchange; no mineral dissolution;

Result: acidic $\mathrm{pH}$;

elevated $\mathrm{Na}, \mathrm{Cl}$

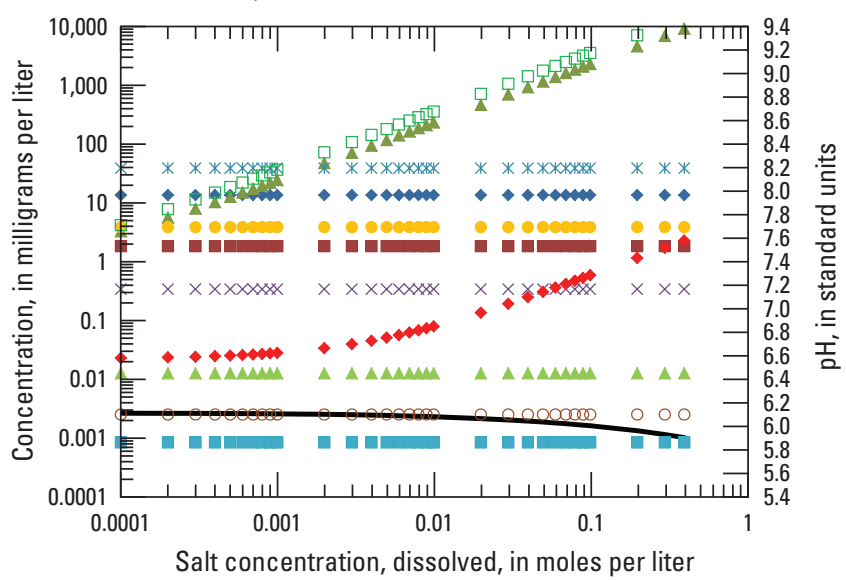

C

Groundwater + deicing salt + calcite dissolution; no cation exchange;

Result: near-neutral $\mathrm{pH}$;

elevated $\mathrm{Na}, \mathrm{Cl}, \mathrm{Ca}$, ANC

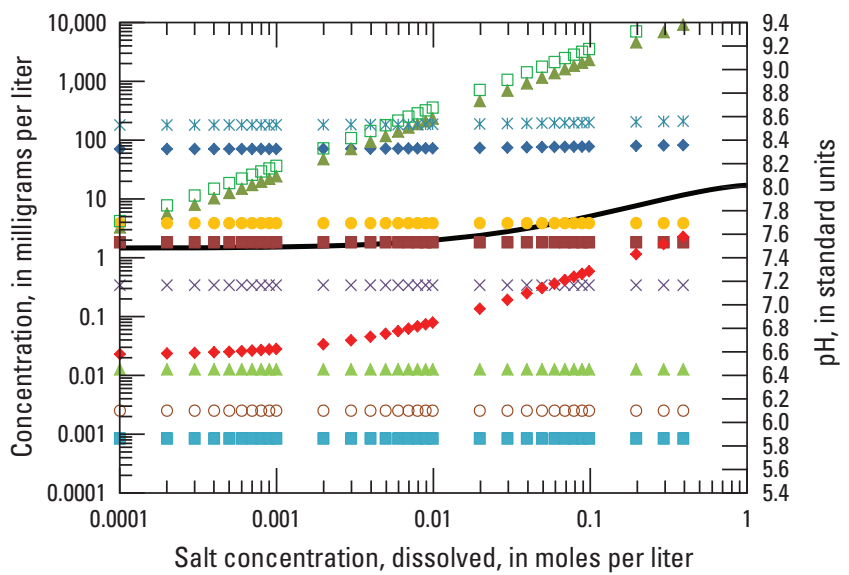

B

Groundwater + brine mixture;

no cation exchange; no mineral dissolution;

Result: acidic $\mathrm{pH}$;

low $\mathrm{SO}_{4^{\prime}}$ ANC; elevated $\mathrm{Cl}, \mathrm{Br}, \mathrm{Na}, \mathrm{K}, \mathrm{Li}, \mathrm{Sr}, \mathrm{Ba}, \mathrm{Ca}, \mathrm{Mg}$

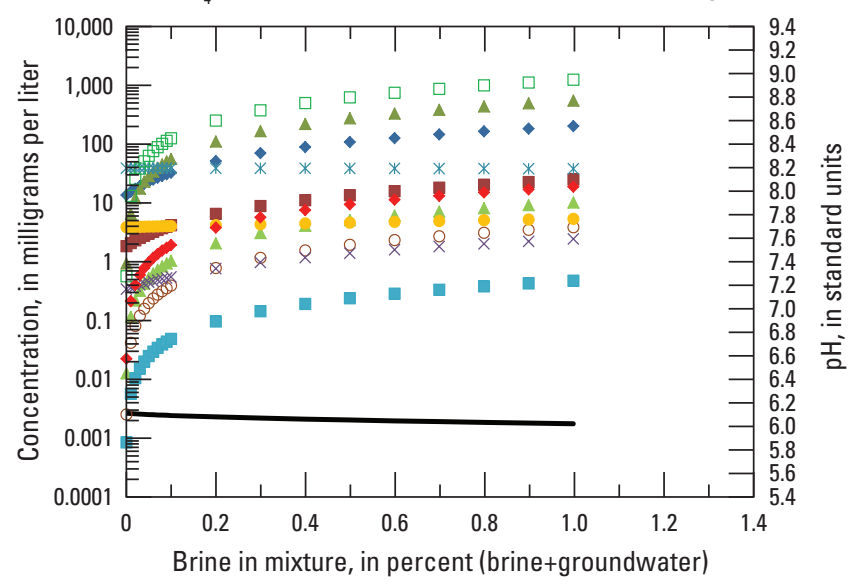

D

Groundwater + brine mixture + calcite dissolution; Result: near-neutral $\mathrm{pH}$;

low $\mathrm{SO}_{4}$; elevated $\mathrm{Cl}, \mathrm{Br}, \mathrm{Na}, \mathrm{K}$, $\mathrm{Li}, \mathrm{Sr}, \mathrm{Ca}, \mathrm{Mg}$

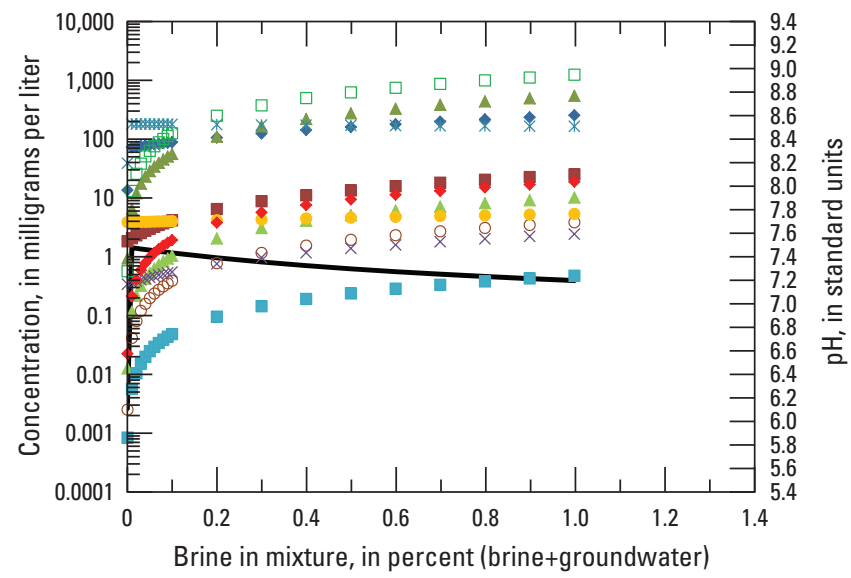

EXPLANATION

\begin{tabular}{|c|c|c|c|}
\hline & pH & $x$ & Potassium (K) \\
\hline - & Calcium (Ca) & - & Lithium (Li) \\
\hline - & Magnesium (Mg) & * & Acid neutralizing capacity (ANC) \\
\hline$\Delta$ & Strontium (Sr) & - & Sulfate $\left(\mathrm{SO}_{4}\right)$ \\
\hline$\circ$ & Barium (Ba) & 口 & Chloride (CI) \\
\hline$\Delta$ & Sodium (Na) & • & Bromide (Br) \\
\hline
\end{tabular}

Figure 28. Computed compositions of waters resulting from initial composition of low-ionic strength groundwater (from well WN-371) with dissolution of road deicing salt $\left(\mathrm{NaCl}_{0.99996} \mathrm{Br}_{0.00004}\right)$ and (or) calcite, but without cation exchange. Low ionic strength groundwater (WN-371) with $A$, dissolution of deicing salt but without other reactions, $B$, mixing with median oil and gas well brine but without other other reactions, $C$, dissolution of deicing salt plus calcite $\left(\mathrm{CaCO}_{3}\right)$ dissolution to equilibrium (saturation index $=0$ ), and $D$, mixing with median oil and gas well brine plus calcite dissolution to equilibrium. Computations conducted using the aqueous geochemical computer program, PHREEQC (Parkhurst and Appelo, 2013). [Median oil and gas well brine composition from Dresel and Rose (2010)] 
A

Groundwater + calcite dissolution;

no cation exchange;

Result: near-neutral $\mathrm{pH}$;

elevated $\mathrm{Ca}$, ANC

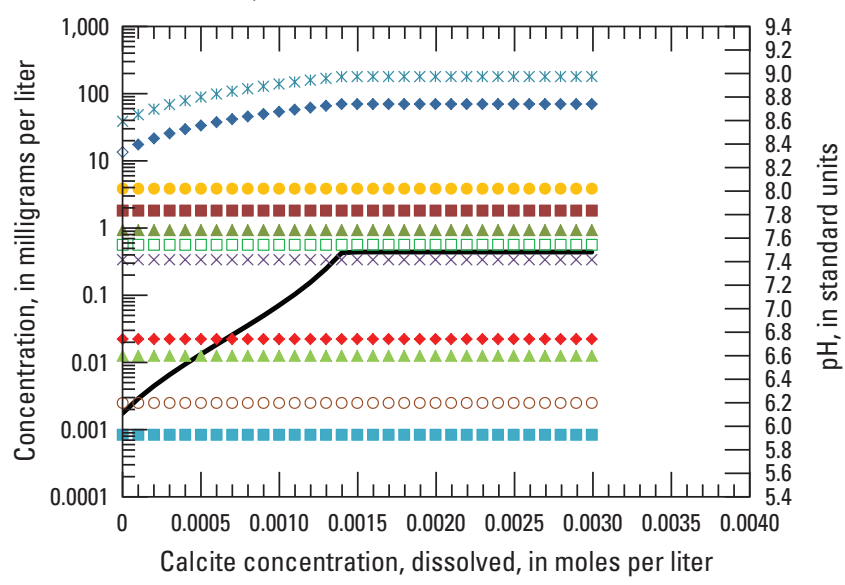

C

Groundwater + brine mixture + cation exchange;

no mineral dissolution;

Result: acidic $\mathrm{pH}$;

low $\mathrm{SO}_{4}, \mathrm{Ca}, \mathrm{Mg}$; elevated $\mathrm{ANC}, \mathrm{Cl}, \mathrm{Br}, \mathrm{Na}$, $\mathrm{K}$, $\mathrm{Li}$

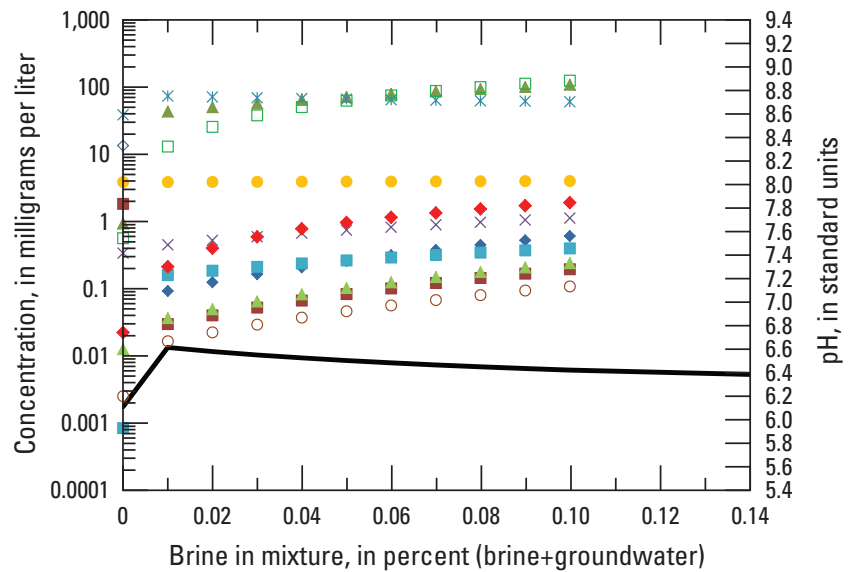

B Groundwater + calcite dissolution + cation exchange Result: alkaline $\mathrm{pH}$;

low $\mathrm{Cl}, \mathrm{Br}, \mathrm{SO}_{4}, \mathrm{Ca}, \mathrm{Mg}$; elevated $\mathrm{ANC}, \mathrm{Na}$, $\mathrm{K}$, Li, $\mathrm{Sr}, \mathrm{Ba}$

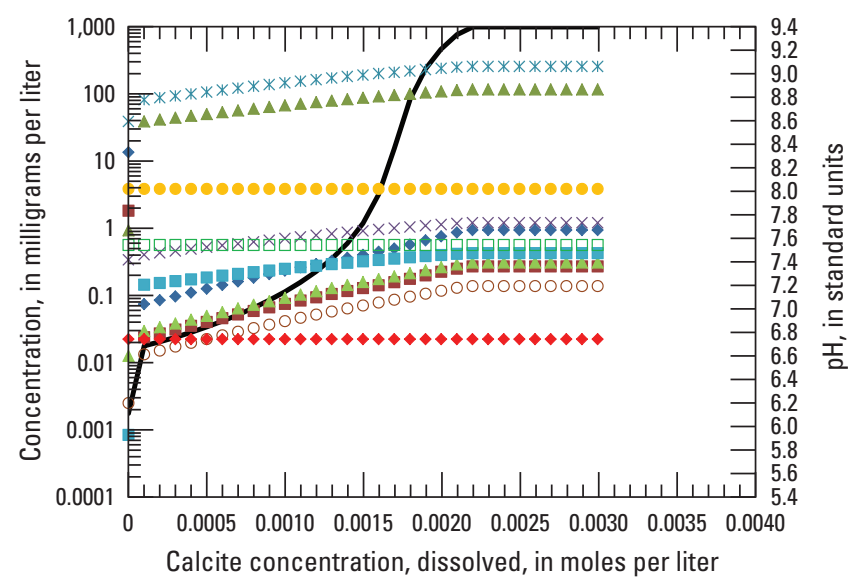

D

Groundwater + brine mixture + calcite dissolution + cation exchange;

Result: alkaline $\mathrm{pH}$;

low $\mathrm{SO}_{4}, \mathrm{Ca}, \mathrm{Mg}$; elevated $\mathrm{ANC}, \mathrm{Cl}, \mathrm{Br}, \mathrm{Na}, \mathrm{K}, \mathrm{Li}, \mathrm{Sr}, \mathrm{Ba}$

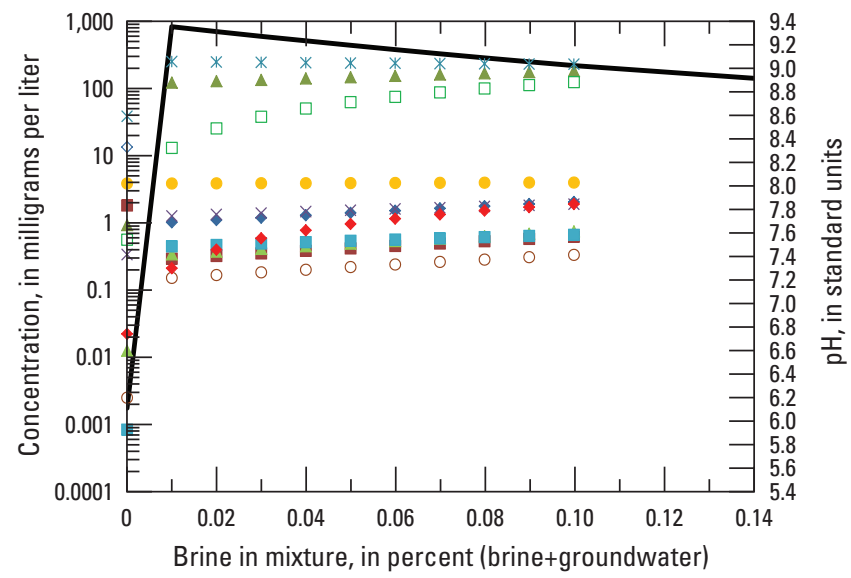

EXPLANATION

\begin{tabular}{|c|c|c|c|}
\hline & $\mathrm{pH}$ & $x$ & Potassium (K) \\
\hline - & Calcium (Ca) & - & Lithium (Li) \\
\hline - & Magnesium (Mg) & * & Acid neutralizing capacity (ANC) \\
\hline$\Delta$ & Strontium $(\mathbf{S r})$ & $\bullet$ & Sulfate $\left(\mathrm{SO}_{4}\right)$ \\
\hline$\circ$ & Barium (Ba) & 口 & Chloride (CI) \\
\hline$\Delta$ & Sodium (Na) & - & Bromide (Br) \\
\hline
\end{tabular}

Figure 29. Computed composition of waters resulting from initial composition of low-ionic strength groundwater (from well WN-371) with reactions including dissolution of calcite and (or) cation exchange and (or) mixing with different amounts of brine. Low-ionic strength groundwater (WN-371) with dissolution of incremental amounts of calcite $\left(\mathrm{CaCO}_{3}\right)$ until reaching equilibrium $A$, without cation exchange, $B$, with cation exchange. Low-ionic strength groundwater (WN-371) mixes with median oil and gas well brine $C$, with cation exchange, and $D$, with calcite dissolution to equilibrium and cation exchange. Computations conducted using the aqueous geochemical computer program, PHREEOC (Parkhurst and Appelo, 2013). [Median oil and gas well brine composition from Dresel and Rose (2010)] 
these models, instead of road deicing salt, calcite was added progressively to the initial groundwater, without or with cation exchange (fig. 29A and B). Likewise, the groundwater plus brine mixing scenarios are considered with cation exchange, without or with calcite dissolution (fig. 29C and D). Generally, calcite dissolution alone could produce near-neutral calcium/ bicarbonate waters, which were the most common types. Furthermore, a mixture of 0.01 percent to 0.07 percent brine plus groundwater could produce the observed concentrations of bromide and chloride plus other major and trace ions. However, calcite dissolution plus cation exchange was required to produce the elevated $\mathrm{pH}, \mathrm{ANC}$, and sodium concentrations. The exchange sites were modeled as containing mostly sodium, with minor calcium, magnesium, strontium, barium, and lithium (instead of all sodium). Thus, observed concentrations of strontium, barium, and lithium could be maintained or increased through the exchange reactions.

\section{Conceptual Hydrogeochemical Model}

The conceptual model for geochemical evolution of groundwater for the area of study involves chemical reactions in the recharge areas and along the flow paths. A schematic diagram illustrating the conceptual model of how waterquality is thought to evolve along local and regional groundwater flow paths, based on the data analysis presented in this report, is shown in figure 30. Recently (less than a few years) recharged shallow groundwater in the uplands likely had limited interaction with aquifer and soil materials, and consequently, has relatively low $\mathrm{pH}$, low TDS, and high DO concentrations. The precipitation that recharges aquifers in northeastern Pennsylvania is dilute and acidic, although currently (2015) less acidic than it was 30 years ago. The $\mathrm{pH}$ of precipitation has increased from about 4.2 in 1985 to about 5.0 in 2013 (National Atmospheric Deposition Program, 2016).

Following recharge in the shallow part of the aquifer, groundwater continues to interact with aquifer materials, and soluble minerals, such as calcite, begin to dissolve. As calcite dissolves, $\mathrm{pH}$ rises to near neutral, and calcium, magnesium, and bicarbonate (alkalinity) concentrations increase. Hardness (a measure of calcium and magnesium) reaches a maximum near $\mathrm{pH}$ of 7.5. Along the groundwater flow paths, oxygen is consumed by various biochemical reactions involving oxidation of organic material in soils or aquifer, or by oxidation of some minerals, such as pyrite. Exchange of alkali metals (sodium, lithium) for alkaline earth metals (calcium, magnesium, and to a lesser extent barium and strontium) on mineral surfaces (such as illite, a mineral reported to be present in aquifer materials) is thought to occur, based on apparent relations between various constituents, and was included in the geochemical model. Through ion exchange, concentrations of calcium and magnesium decrease while sodium and other alkali metals, alkalinity, and $\mathrm{pH}$ continue to increase. The increases in $\mathrm{pH}$ and alkalinity result from the progressive dissolution of calcite, to maintain equilibrium, as calcium and magnesium are removed from solution by exchange processes. The shift in groundwater composition from $\mathrm{Ca}$ and $\mathrm{Mg}$ as the predominant cations (for example, well $\mathrm{WN}-371$ ) to $\mathrm{Na}$ as the predominant cation (for example, well WN-295) is shown on Piper diagrams (fig. 23B, C). This shift from calcium to sodium as predominant cation generally is accompanied by increases in TDS (fig. 23B). Formation of sodium-bicarbonate waters with elevated $\mathrm{pH}$ as a result of ion-exchange (sodium for calcium) has been reported for shallow shale aquifers elsewhere (Kresse and others, 2012). Plots showing simulated changes in concentrations and $\mathrm{pH}$ though modeled chemical processes are shown in figs. 28 and 29. At $\mathrm{pH}$ values greater than 8 , oxyanions, such as arsenate, are mobilized, resulting in increases in dissolved concentrations of arsenic and other trace elements with similar chemical properties.

Mixing of groundwater with brines or other saline waters from deep parts of the aquifer or areas of restricted flow (low permeability) contributes certain constituents, such as bromide and chloride. Wells that penetrate deep parts of the aquifer or are near areas of regional groundwater discharge appear to be most likely to intercept groundwater with a saline component. Geochemical modeling indicates that the measured (observed) concentrations of chloride and bromide in the Wayne County groundwater samples with the highest concentrations of bromide could result from a mixture of freshwater and brine, with brine representing less than 0.02 percent of the solution (see fig. 29). Other sources of chloride include road salt and septic effluent. Contributions of chloride from low-bromide manmade sources to shallow groundwater that has not undergone extensive ion exchange results in the type of water exemplified by water samples from wells WN-307 and WN-400 (figs. 23C and 24B). The evolution pathway indicated for groundwater plus road deicing salt produces sodium/chloride water type (on the right corner of the Piper diagram), as does mixing of groundwater with brine plus cation exchange, with or without calcite dissolution (fig. 23D).

These findings and chemical models indicate that the waters with elevated methane concentrations (greater than $1 \mathrm{mg} / \mathrm{L}$ ) in Wayne County appear to have been formed by a series of chemical reactions, including mineral dissolution, ion exchange, and some mixing with brine. These types of waters appear distinct from other groundwater types in Wayne County, although they may have formed gradually.

Brines with elevated concentrations of sodium, chloride, bromide, barium, strontium, and other solutes occupy pore spaces in deep-lying sedimentary rocks throughout Pennsylvania. The highly saline sodium/chloride brines and overlying groundwaters of intermediate salinity generally are present 1,000 feet or more below the surface (Feth and others, 1965; Heisig and Scott, 2013). Such brine-affected waters typically discharge from gas or oil wells (Dresel and Rose, 2010) and may be present locally at springs and some shallow water wells in northeastern Pennsylvania (Llewellyn, 2014). 


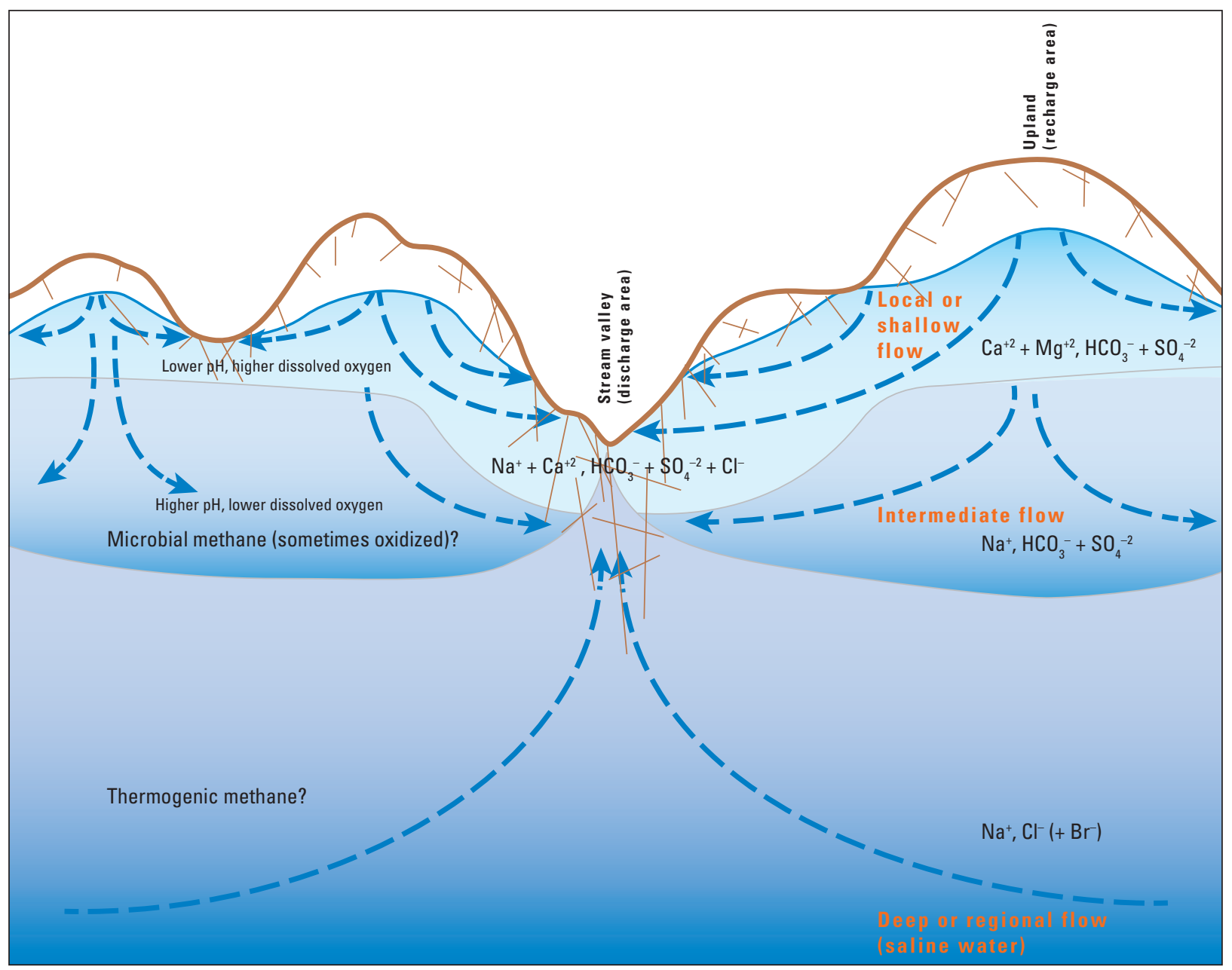

Not to scale

EXPLANATION

$$
\begin{array}{ll}
\mathrm{Ca}^{+2}-\text { Calcium } & \mathrm{Br}-\mathrm{Bromide} \\
\mathrm{Mg}^{+2}-\text { Magnesium } & \mathrm{Cl}^{-}-\text {Chloride } \\
\mathrm{Na}^{+}-\text {Sodium } & \mathrm{HCO}_{3}^{-}-\text {Bicarbonate } \\
\mathrm{SO}_{4}^{-2}-\text { Sulfate } & \\
\longrightarrow & \text { Directon of groundwater flow }
\end{array}
$$

Figure 30. Schematic diagram of generalized conceptual hydrogeochemical model for distribution of fresh and saline groundwater in fractured bedrock aquifer setting. Groundwater-flow directions shown in blue with local, intermediate, and regional flow paths indicated. Groundwater composition evolves from calcium-magnesium-bicarbonate-sulfate type with relatively low pH and high dissolved oxygen concentrations (DO) in recharge areas and local flow zones to predominantly sodium-bicarbonate-sulfate with higher $\mathrm{pH}$ and lower DO along intermediate flow paths. Deeper or regional water that is relatively saline may be mixing with intermediate-flow waters, especially in discharge areas, such as stream valleys, where methane from microbial and (or) thermogenic sources appears to be present most frequently and at highest concentrations in northeastern Pennsylvania. 
The shallowest flow systems tend to be present in highly fractured aquifers where actively circulating freshwater over time has depleted sodium, chloride, and other vestiges of connate brines (fluids trapped in rocks during and after formation). In the shallow groundwater zone (fig. 30), water types of predominantly calcium-magnesium/bicarbonate and calcium-magnesium/bicarbonate-sulfate compositions are produced by the active weathering of moderately soluble carbonate minerals, and to a lesser extent sulfate, sulfide, and silicate minerals. In the intermediate zone, groundwater of sodium/ bicarbonate type and moderate salinity typically is present between the shallow, actively circulating freshwater and the deeper, slower moving sodium/chloride type water. Poth (1963) explains the freshening process in the intermediate zone as follows: " $(\mathrm{t}) \mathrm{he}$ chloride is readily removed by circulating ground water, but the sodium is more difficult to remove because much of it is adsorbed on the clay in the rocks." The sodium, which occupies exchange sites on clay minerals, tends to be displaced by calcium and magnesium though cation exchange. Such processes lead to the formation of sodium/ bicarbonate type waters, which are transitional between the sodium/chloride waters at great depth and the calcium-magnesium/bicarbonate waters in the overlying freshwater zone.

Most wells constructed for domestic use are completed within the local, freshwater flow system. All but one well sampled for this study in Wayne County were completed at depths ranging from 14 to $740 \mathrm{ft}$ below land surface; one-half of these were drilled to depths of 200 to $380 \mathrm{ft}$. One well, $\mathrm{WN}-309$, was completed at a depth of 1,300 ft below land surface; a single low-yielding water bearing zone was reported at $988 \mathrm{ft}$. The water sampled from WN-309 exhibited characteristics of brine affected water, notably elevated specific conductance and dissolved solids dominated by sodium and chloride plus elevated concentrations of bromide, lithium, and methane. Some other wells that were shallower in depth and located within stream valleys where deep groundwater may be discharging had similar types of brine affected waters, including wells WN-295 (225 ft deep) and WN-341 (230 ft deep) (fig. 5).

Statistically significant correlations indicated an inverse relation between both land surface and well-bottom elevation and constituents associated with factor PC1 (table 9), including $\mathrm{pH}$, lithium, and sodium. These correlations support the conceptual model (fig. 30) by showing that the more evolved waters tend to be present at lower elevations (less than about 1,200 to $1,500 \mathrm{ft}$ above the North American Vertical Datum of 1988) and, in some cases, at greater depths (> 1,000 ft below land surface) in the aquifer. The apparent lack of strong relations between groundwater quality and TPI (index for local topographic setting that does not account for regional setting) (see Appendix 4-5) also supports the conceptual model because shallow local flow discharging to upland valleys likely would not have undergone as extensive chemical evolution as water that discharges regionally to lowland valleys and major streams.

\section{Spatial Distribution of Groundwater Quality and Relation to Hydrogeologic Setting}

The observed distributions of water types, and $\mathrm{pH}$, methane, and trace elements, such as lithium, vary spatially throughout Wayne County and, in some cases, exhibit apparent relations to hydrogeologic setting. In the highlands along the western and southern areas of Wayne County, groundwater tends to be relatively more dilute, with lower $\mathrm{pH}$, and higher DO concentrations; these areas correspond to the recharge area on the generalized conceptual schematic of groundwater flow (fig. 30). At lower elevations in Wayne County, groundwater has higher $\mathrm{pH}$, dissolved solids, alkalinity, and hardness; these areas correspond to the intermediate flow zone on the generalized conceptual schematic (fig. 30). This schematic is similar to that presented by Siegel and others (2015) for a generalized Appalchian Plateau hydogeologic setting, which would pertain to Wayne County. In selected stream valleys in Wayne County, some groundwater samples had high $\mathrm{pH}$ (greater than 8) and elevated concentrations of sodium, lithium, boron, bromide, fluoride, and methane; these areas correspond to the valley settings on the generalized conceptual schematic diagram in figure 30, where groundwaters from shallow local, intermediate, and deep regional flow zones mix. Similar occurrences of relatively elevated methane in groundwater associated with valley hydrogeologic settings have been reported for nearby areas of New York with similar geology. In a study of methane in groundwater in Upper Devonian shale bedrock in south-central New York, methane concentrations were found to differ by hydrogeologic setting, with the highest concentrations measured in water from wells in confined valley settings and the lowest concentrations in water from wells in upland unconfined settings (Heisig and Scott, 2013).

The spatial distribution of $\mathrm{pH}$ values for samples from 117 wells sampled in 2013 and 2014 shows the lowest $\mathrm{pH}$ values $(<6.5$, acidic water) in the highlands along the western and southern areas of Wayne County and in an area along the eastern border with Pike County (figs. 1 and 6). Groundwater with near neutral $\mathrm{pH}$ (6.5 to 7.5) tends to be present in the central part of the county at intermediate land-surface elevations. Groundwater with highest $\mathrm{pH}(>8.0$, alkaline water) tends to be present in stream valleys. This observed distribution of pH is consistent (fig. 6) with a conceptual model that shows groundwater in upland areas is young, dilute, and acidic, and groundwater at lower elevations has higher $\mathrm{pH}$ and TDS acquired through mineral dissolution. Groundwater samples with the highest $\mathrm{pH}(>8)$, collected in stream valleys, appear to represent waters that have undergone cation exchange and have mixed with a small amount of brine. Differences in $\mathrm{pH}$ in relation to elevation are indicated by boxplots showing the distribution in elevations of well bottoms and land surfaces for four groups of $\mathrm{pH}$ ranges (fig. 31); the most acidic ( $\mathrm{pH}$ $<6.5)$ groundwater is associated with wells with the highest land surface and well bottom elevations (where well bottom elevation is calculated by subtracting well depth from land surface elevation), and the most alkaline groundwater $(\mathrm{pH}>8)$ 

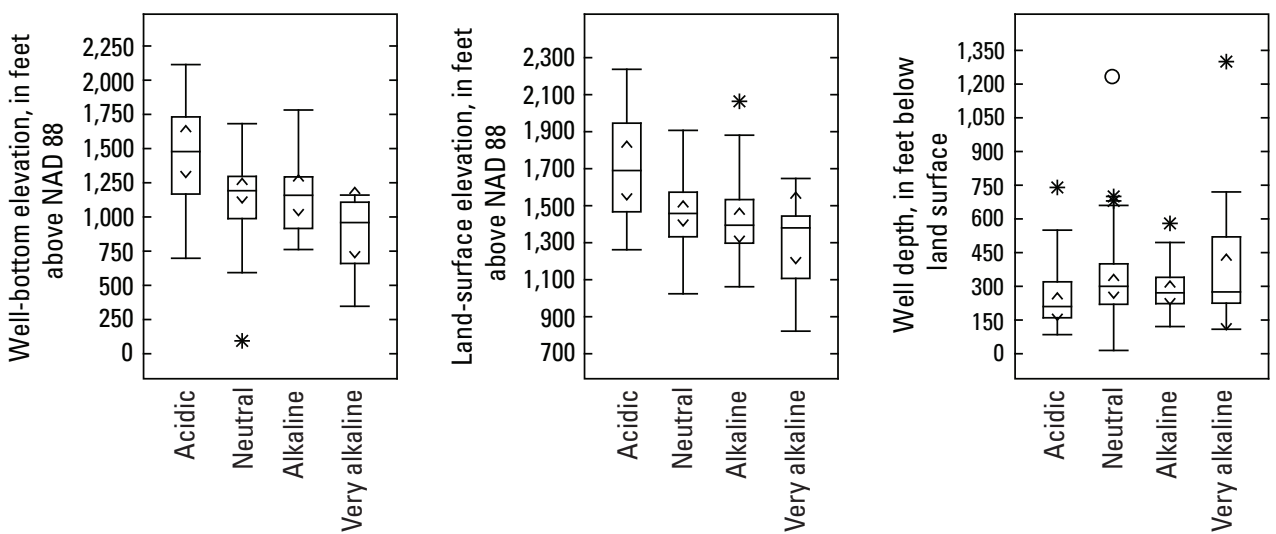

\section{EXPLANATION}

O Outlier data value greater than 3 times the interquartile range outside the quartile

* Outlier data value less than or equal to 3 and greater than 1.5 times the interquartile range outside the quartile

Data value less than or equal to 1.5 times the interquartile
range outside the quartile
75th percentile
Upper notch
Median
Lower notch
25th percentile

Figure 31. Boxplots showing distribution of well bottom elevations, land surface elevations, and well depths for groundwater samples from 117 wells in Wayne County, Pennsylvania, 2013-14, grouped by pH class interval as "acidic" $(5.4<\mathrm{pH}<6.4$, $\mathrm{n}=29)$, "neutral" $(6.5<\mathrm{pH}$ $<7.4, \mathrm{n}=32)$, "alkaline" (7.5< $\mathrm{pH}<7.9, \mathrm{n}=25)$, and "very alkaline" $(8.0<\mathrm{pH}<9.4, \mathrm{n}=9)$. Elevations are in feet above North American Vertical Datum 1988 and well depth in feet below land surface. Well-bottom elevation is calculated by subtracting well depth from land-surface elevation.

is associated with wells with the lowest land surface and well bottom elevations. Little to no relation between $\mathrm{pH}$ and well depth is indicated by the data (fig. 31).

The $\mathrm{pH}$ may also reflect aquifer mineralogy; for example, the area of low $\mathrm{pH}(<6.5)$ along the southeastern border with Pike County (fig. 6) may indicate a sparsity of calcite in aquifer materials. Additionally, the geologic units that underlie uplands typically are more resistant to erosion and, consequently, may contain a smaller amount of relatively soluble minerals (such as calcite in the humid climate of northeastern Pennsylvania) than those geologic units that underlie lowlands.

The samples with highest $\mathrm{pH}$ also generally have the highest concentrations of dissolved methane, sodium, lithium, boron, bromide, and fluoride and among the highest concentrations of arsenic (fig. 22), in addition to the highest concentrations of dissolved ammonia. Most of these constituents were identified through statistical analysis to correlate with each other generally group together (factor PC1); lithium is the most strongly correlated constituent. Elevated lithium concentrations show a strong relation to elevated methane concentrations and are present in samples with the highest $\mathrm{pH}$, mostly in stream valley settings (figs. 6 and 19). Similar relations among constituents were apparent in studies of groundwater quality in nearby Pike County (Senior, 2014) and Sloto (2013). Some of these constituents, such as bromide, may indicate a small amount of brine mixing with fresh groundwater, which has evolved in chemical composition along a flow path and discharges to stream valleys.

Concentrations of arsenic exceeding the MCL of $10 \mathrm{mg} / \mathrm{L}$ generally were associated with the higher $\mathrm{pH}$ waters $(>7.8 \mathrm{pH}$; fig. 12), reflecting geochemical controls on the solubility of arsenic. Concentrations of arsenic exceeding the HA level of $2 \mathrm{mg} / \mathrm{L}$ were most frequently measured in samples from wells in the Lackawaxen drainage in central Wayne County (fig. 5), where $\mathrm{pH}$ values were near or greater than neutral $(\mathrm{pH}>7)$. This central area of Wayne County also had among the highest concentrations of radon-222 and uranium in groundwater samples (figs. 16 and 18, respectively), which may indicate that the aquifer materials are relatively enriched in uranium and daughter products. The presence of uranium associated with an old copper prospect in Waymart Township, west-central Wayne County (fig. 2), was described by Klemic (1962). 


\section{Summary and Conclusions}

In 2014, the U.S. Geological Survey, in cooperation with the Wayne Conservation District, conducted a study to assess baseline shallow groundwater quality in bedrock aquifers prior to possible shale-gas development in the county. Wayne County in northeastern Pennsylvania is underlain by nearly flat-lying Pennsylvanian-age and older sedimentary rocks, including the Devonian-age Marcellus Shale and Ordovician-age Utica Shale, formations that have potential for natural gas development and are being developed elsewhere in Pennsylvania as near as adjacent Susquehanna County. The Marcellus Shale is present from less than approximately 2,000 feet ( $\mathrm{ft}$ ) below land surface in southern Wayne County to more than 7,000 ft below land surface in western Wayne County. The Utica Shale is present thousands of feet below the Marcellus Shale. Bedrock units nearest the land surface in Wayne County form fractured bedrock aquifers, which are recharged by precipitation and discharge locally to streams and regionally to rivers. Glacial deposits that partly cover the bedrock units are minor sources of groundwater. In rural Wayne County, groundwater is the primary source of supply; most wells are completed in bedrock aquifers.

The 2014 study expanded on a previous study done in 2013, for which 32 wells were sampled in Wayne County. Eighty-nine wells were sampled in summer 2014 to provide data on the presence of methane and other aspects of existing groundwater quality throughout the county, including concentrations of inorganic constituents typically present at low concentrations in shallow, fresh groundwater but elevated in brines associated with fluids extracted from geologic formations during shale-gas development. Depths of sampled wells ranged from 85 to $1,300 \mathrm{ft}$, with a median of $291 \mathrm{ft}$. All groundwater samples collected in Wayne County in 2014 were analyzed for bacteria, major ions, nutrients, selected inorganic trace constituents (including metals and other elements), selected organic compounds (including volatile organic compounds and glycols), radon-222, gross alpha- and gross beta-particle activity, dissolved gases (methane, ethane, and propane), and if possible, the isotopic composition of methane.

Results of the 2014 sampling show that groundwater quality generally met most drinking-water standards, but some samples had one or more constituents or properties, including arsenic, iron, $\mathrm{pH}$, bacteria, and radon-222, that exceeded primary or secondary maximum contaminant levels (MCLs). Arsenic concentrations were higher than the MCL of 10 micrograms per liter $(\mu \mathrm{g} / \mathrm{L})$ in 8 of the 89 well-water samples ( 9 percent), with measured concentrations as high as $20 \mu \mathrm{g} / \mathrm{L}$; arsenic concentrations were higher than the Health Advisory (HA) level of $2 \mu \mathrm{g} / \mathrm{L}$ in 27 of 89 samples (30 percent). Total iron concentrations exceeded secondary maximum contaminant level (SMCL) of $300 \mu \mathrm{g} / \mathrm{L}$ in 9 of the 89 samples. The $\mathrm{pH}$ ranged from 5.4 to 9.3 and did not meet the SMCL range of 6.5 to 8.5 in 27 of 89 samples ( 30 percent). Twenty-two samples had pH less than 6.5, and 5 samples had $\mathrm{pH}$ greater than 8.5. Total coliform bacteria were detected in
22 of 89 samples (25 percent); Escherichia coli (E.Coli) were detected in only 2 of 22 samples. Radon-222 activities ranged from 25 to 7,400 picocuries per liter ( $\mathrm{pCi} / \mathrm{L}$ ), with a median of $2,120 \mathrm{pCi} / \mathrm{L}$, and exceeded the proposed drinking-water standard of $300 \mathrm{pCi} / \mathrm{L}$ in 86 of the 89 samples (97 percent); radon-222 activities were higher than the alternative proposed standard of $4,000 \mathrm{pCi} / \mathrm{L}$ in 12 of 89 samples (13 percent). Although no sample had uranium concentrations greater than the MCL of $30 \mu \mathrm{g} / \mathrm{L}$, one sample had a concentration $(16.4 \mu \mathrm{g} / \mathrm{L})$ that was close to the HA of $20 \mu \mathrm{g} / \mathrm{L}$.

Water from 8 ( 9 percent) of 89 wells sampled in 2014 had concentrations of methane greater than the reporting level of 0.24 milligrams per liter $(\mathrm{mg} / \mathrm{L})$; in samples from the 8 wells, the detectable methane concentrations ranged from 0.74 to $9.6 \mathrm{mg} / \mathrm{L}$. Low levels of ethane (up to $0.0017 \mathrm{mg} / \mathrm{L}$ ) were measured in the six samples with the highest methane concentrations. The isotopic composition of methane in 6 of 8 samples with sufficient dissolved methane (about $1 \mathrm{mg} / \mathrm{L}$ ) for isotopic analysis is consistent with a predominantly thermogenic methane source (sample $\delta^{13} \mathrm{C}_{\mathrm{CH} 4}$ values ranging from $-56.36 \%$ to $-45.97 \%$ and $\delta \mathrm{D}_{\mathrm{CH} 4}$ values ranging from -233.1 parts per thousand (\%o) to $-141.1 \%$ ); however, the low levels of ethane relative to methane indicate that the methane may be of microbial origin that subsequently underwent oxidation. Isotopic compositions indicated a possibly mixed thermogenic and microbial source (carbon dioxide reduction process) for the methane in another sample $\left(\delta^{13} \mathrm{C}_{\mathrm{CH} 4}\right.$ of $-63.72 \%$ and $\delta \mathrm{D}_{\mathrm{CH} 4}$ of $-192.3 \%$ ) and potential oxidation of microbial and (or) thermogenic methane in the remaining sample $\left(\delta^{13} \mathrm{C}_{\mathrm{CH} 4}\right.$ of $-46.76 \%$ and $\delta \mathrm{D}_{\mathrm{CH} 4}$ of $-79.7 \%$ ).

The groundwater with elevated methane concentrations had a chemical composition that differed in some respects ( $\mathrm{pH}$, selected major ions, and inorganic trace constituents) from groundwater with low methane concentrations. The seven well-water samples with the highest methane concentrations (from about 1 to $9.6 \mathrm{mg} / \mathrm{L}$ ) also had among the highest $\mathrm{pH}$ values (8.1 to 9.3, respectively) and highest concentrations of sodium, lithium, boron, fluoride, arsenic, ammonia, and bromide. Elevated concentrations of some other constituents, such as barium, strontium, and chloride, commonly were not limited to well-water samples with elevated methane.

Relations among chemical constituents were investigated through statistical (principal component analysis; PCA) and graphical (Piper diagrams, scatter plots, and boxplots) methods, which aid in understanding how groundwaters develop different chemical compositions, especially those waters that have elevated concentrations of constituents of concern, such as arsenic and methane. Data from 2013 and 2014 were combined to create a dataset with greater spatial extent, which could be used to better characterize groundwater quality in the county.

Characterization of water by major ion composition shows that most groundwaters are of a calcium-magnesiumbicarbonate-sulfate type; a few samples were mostly a sodium-bicarbonate type. The sodium-bicarbonate type waters generally have low dissolved oxygen and high $\mathrm{pH}$ values, and 
some of the highest concentrations of arsenic. Elevated $\mathrm{pH}$ is an important geochemical control on arsenic concentrations because arsenic tends to be more soluble at $\mathrm{pH}$ values above 7.5. The statistical grouping of constituents through PCA identified four main factors that reflect geochemical processes and man-made contributions.

Groundwater samples with elevated methane concentrations (near or greater than $1 \mathrm{mg} / \mathrm{L}$ ) have chloride/bromide ratios that indicate mixing with a small amount of brine similar in composition to that reported for shale-gas brines in Pennsylvania. Most other samples with low methane concentrations (less than about $1 \mathrm{mg} / \mathrm{L}$ ) have chloride/bromide ratios that indicate predominantly man-made sources of chloride, such as road salt or septic systems.

Results of geochemical modeling of combined 2013 and 2014 data show that water in samples with elevated $\mathrm{pH}$, sodium, lithium, bromide, and alkalinity could have been affected by dissolution of calcite (calcium carbonate), followed by ion exchange, and mixing with a small amount (less than 0.02 percent) of brine. Brine contributions may originate from deep parts of the aquifer system. The spatial distribution of groundwater composition generally shows that relatively dilute, slightly acidic, oxygenated, calciumcarbonate type water tends to be present in the uplands along the western border of Wayne County; water with near neutral $\mathrm{pH}$ and with highest amounts of hardness (calcium and magnesium) generally was present in areas of intermediate elevations. Water with $\mathrm{pH}$ values greater than 8 , low oxygen concentrations, and the highest arsenic, sodium, lithium, bromide concentrations most frequently was present in stream valleys, especially at relatively lower elevations near areas of regional groundwater discharge, such as the Delaware River.

Thus, the baseline assessment of groundwater quality in Wayne County prior to gas-well development shows that shallow (less than about 1,000 ft deep) groundwater is generally of good quality. However, methane and some constituents (sodium, lithium, bromide, boron, and others) that are present in high concentrations in brines and potentially associated with shale-gas development also are present at low to moderate concentrations, and in some areas at relatively elevated concentrations, in groundwater in Wayne County. The flow and transport processes responsible for the presence of methane and the relatively elevated sodium and associated trace constituent concentrations in groundwater in Wayne County are not known. Although isotopic characterization of methane may be used to identify the naturally occurring methane in shallow bedrock aquifers as part of the baseline assessment, additional investigations may be needed to determine the origin of this methane and explain its association with the high $\mathrm{pH}$, sodiumbicarbonate, bromide-enriched groundwater.

Limited results for 4 wells sampled twice 1-year apart (in 2013 and 2014) indicate that temporal variability in water quality may be a factor to consider when establishing baseline water quality. Although some differences may be related to analytical uncertainty, differences greater than 20 percent for constituents occurring in concentrations substantially higher than the reporting level may represent real differences in water quality between samples collected at different times. Additional monitoring through time beyond the one-time sampling conducted for this assessment would be needed to determine seasonal or other types of variability in water quality.

\section{References Cited}

Appelo, C.A.J., and Postma, D., 2005, Geochemistry, groundwater and pollution ( $2 \mathrm{~d}$ ed.): Leiden, The Netherlands, A.A. Balkema Publishers, $649 \mathrm{p}$.

Back, William, 1966, Hydrochemical facies and ground-water flow patterns in northern part of Atlantic Coastal Plain: U.S. Geological Survey Professional Paper 498-A, p. A1-A42, 1 plate in pocket.

Ball, J.W., and Nordstrom, D.K., 1991, User's manual for WATEQ4F with revised database: U.S. Geological Survey Open-File Report 91-183, 189 p.

Baldassare, F.J., McCaffrey, M.A., and Harper, J.A., 2014, A geochemical context for stray gas investigations in the northern Appalachian Basin: Implications of analyses of natural gases from Neogene-through Devonian-age strata: American Association of Petroleum Geologists Bulletin, v. 98 , no. 2, p. 341-372.

Bernard, B.B., Brooks, J.J., and Sackett, W.M., 1978, Light hydrocarbons in recent Texas continental shelf and slope sediments: Journal of Geophysical Research, v 83, p. 4053-4061.

Berg, T.M., Sevon, W.D., and Bucek, M.F., 1977, Geology and mineral resources of the Pocono Pines and Mount Pocono quadrangles, Monroe County, Pennsylvania: Pennsylvania Geological Survey, 4th series, Atlas 204cd, 66 p., 2 plates, scale 1:24,000.

Bethke, C.M., and Yeakel, S., 2010, The Geochemist's Workbench Release 8.0: GWB essentials guide: Champaign, Ill., Aqueous Solutions, LLC.

Breen, K.J., Révész, Kinga, Baldassare, F.J., and McAuley, S.D., 2007, Natural gases in ground water near Tioga Junction, Tioga County, North-Central PennsylvaniaOccurrence and use of isotopes to determine origins, 2005: U.S. Geological Survey Scientific Investigations Report 2007-5085, 65 p.

Carswell, L.D., and Lloyd, O.B., Jr., 1979, Geology and groundwater resources of Monroe County, Pennsylvania: Pennsylvania Geological Survey, 4th Series, Water Resource Report 47, 61 p. 
Chapman, E.C., Capo, R.C., Stewart, B.W., Kirby, C.S., Hammack, R.W., Schroeder, K.T., and Edenborn, H.M., 2012, Geochemical and strontium isotope characterization of produced waters from Marcellus Shale natural gas extraction: Environmental Science \& Technology, v. 46, p. 3545-3553.

Chapman, M.J., Cravotta, C.A. III, Szabo, Zoltan, and Lindsey, B.D., 2013, Naturally occurring contaminants in the Piedmont and Blue Ridge crystalline-rock aquifers and Piedmont Early Mesozoic Basin siliciclastic-rock aquifers, eastern United States, 1994-2008: U. S. Geological Survey Scientific Investigations Report 2013-5072, 74 p.

Coleman, D.D., Liu, C.L., Liu, Chao-Li, Hackley, K.C., and Pelphrey, S.R., 1995, Isotopic identification of landfill methane: Environmental Geosciences, v. 2, no. 2, p. 95-103.

Commonwealth of Pennsylvania, 2014, The Pennsylvania code chapter 78. Oil and gas wells, accessed March 31, 2014, at http:/www.pacode.com/secure/data/025/chapter78/ chap78toc.html.

Cravotta, C.A. III, and Brady, K.B.C., 2015, Priority pollutants in untreated and treated discharges from coal mines in Pennsylvania, U.S.A.: Applied Geochemistry, v. 62, p. 108-130.

Davis, S., Whittemore, D., and Fabryka-Martin, J., 1998, Use of chloride/bromide ratios in studies of potable water: Ground Water, v. 36, p. 338-350.

Delaware River Basin Commission, 2014, Natural gas drilling index page, accessed February 11, 2014, at http://www. state.nj.us/drbc/programs/natural/.

Denver, J.M., Cravotta, C.A., III, Ator, S.W., and Lindsey, B.D., 2010, Contributions of phosphorus from groundwater to streams in the Piedmont, Blue Ridge, and Valley and Ridge Physiographic Provinces, eastern United States: U.S. Geological Survey Scientific Investigations Report 2010-5176, 38 p.

Dresel, P.E., and Rose, A.W., 2010, Chemistry and origin of oil and gas well brines in western Pennsylvania: Pennsylvania Geological Survey, 4th ser., Open-File Report OFOG 10-01.0, 48 p.

Drever, J.I., 1997, The geochemistry of natural waterssurface and groundwater environments ( $3 \mathrm{~d}$ ed.): Upper Saddle River, N.J., Prentice Hall, 436 p.

Dufor, C.N., and Becker, Edith, 1964, Public water supplies of the 100 largest cities in the United States, 1962: U.S. Geological Survey Water-Supply Paper 1812, 364 p.

Duro, L., Grivé, M., and Giffaut E., 2012. ThermoChimie, the ANDRA thermodynamic database: MRS Proceedings, 1475, imrc11-1475-nw35-o71 doi:10.1557/op1.2012.637.
Dzombak, D.A., and Morel, F.M.M., 1990, Surface complexation modeling-Hydrous ferric oxide: New York, John Wiley \& Sons, Inc., 393 p.

Eckhardt, D.A., and Sloto, R.A., 2012, Baseline groundwater quality in national park units within the Marcellus and Utica Shale gas plays, New York, Pennsylvania, and West Virginia, 2011: U.S. Geological Survey Open-File Report 2012-1150, 20 p.

Ehrlich, H.L, 1990, Geomicrobiology (2d ed.): New York, Marcel-Dekker, Inc., 646 p.

Eltschlager, K.K., Hawkins, J.W., Ehler, W.C., and Baldassare, Fred, 2001, Technical measures for the investigation and mitigation of fugitive methane hazards in areas of coal mining: U.S. Department of Interior, Office of Surface Mining Reclamation and Enforcement, 129 p.

Federal Register, 1999, National primary drinking water regulations; radon-222: Federal Register, v. 64, no. 211, p. 59245-59294.

Feth, J.H., and others, 1965, Preliminary map of the conterminous United States showing depth to and quality of shallowest ground water containing more than 1,000 parts per million dissolved solids: U.S. Geological Survey Hydrologic Atlas 199.

Fishman, M.J., and Friedman, L.C., eds., 1989, Methods for determination of inorganic substances in water and fluvial sediments: U.S. Geological Survey Techniques of WaterResources Investigations, book 5, chap. A1, 545 p.

Friend, P.F., 1966, Clay fractions and colours of some Devonian red beds in the Catskill mountains, U.S.A.: Quarterly Journal of the Geological Society, v. 122, p. 273-288.

Haluszczak, L.O., Rose, A.W., and Kump, L.R., 2013, Geochemical evaluation of flowback brine from Marcellus gas wells in Pennsylvania, USA: Applied Geochemistry, v. 28 , p. 55-61.

Hanor, J. S., 1968, Frequency distribution of compositions in the barite-celestite series: American Mineralogist, v. 53, p. 1215-1222.

Hanshaw, B.B., and Back, William, 1979, Major geochemical processes in the evolution of carbonate-aquifer systems: Journal of Hydrology, v. 43, p. 287-312.

Harrison, M.J., Marshak, Stephen, and McBride, J.H., 2004, The Lackawanna synclinorium: a salt-collapse structure, partially modified by thin-skinned folding: Geological Society of America Bulletin v. 116, no. 11/12, p. 1499-1514. 
Hayes, T., 2009, Sampling and analysis of water streams associated with the development of Marcellus shale gas. Report by Gas Technology Institute, Des Plaines, IL, for the Marcellus Shale Coalition, accessed at http://www. bucknell.edu/script/environmentalcenter/marcellus/default. aspx? articleid $=14$.

Heisig, P.M., and Scott, Tia-Marie, 2013, Occurrence of methane in groundwater of south-central New York State, 2012 - Systematic evaluation of a glaciated region by hydrogeologic setting: U.S. Geological Survey Scientific Investigations Report 2013-5190, 32 p.

Helsel, D.R. and Hirsch, R.M., 2002, Statistical methods in water resources: U.S. Geological Survey Techniques of Water-Resources Investigations, book 4, chap. A3, 523 p.

Hem, J.D., 1985, Study and interpretation of the chemical characteristics of natural waters ( $3 \mathrm{~d}$ ed.): U.S. Geological Survey Water-Supply Paper 2254, 263 p.

Johnson, J.D., Graney, J.R., Capo, R.C., and Stewart, B.W., 2015 , Identification and quantification of regional brine and road salt sources in watersheds along the New York/ Pennsylvania border, USA: Applied Geochemistry, v. 60, p. 37-50.

Joreskog, K.G., Klovan, J.E., and Reyment, R.A., 1976, Geological factor analysis: New York, Elsevier, 178 p.

Kargbo, D.M., Wilhelm, R.G., and Campbell, D.J., 2010, Natural gas plays in the Marcellus shale-Challenges and potential opportunities: Environmental Science and Technology, v. 44, p. 5679-5684.

Kerr, R.A., 2010, Natural gas from shale bursts onto the scene: Science, v. 328, p. 1624-1626.

Kirschbaum, M.A., Schenk, C.J., Cook, T.A., Ryder, R.T., Charpentier, R.R., Klett, T.R., Gaswirth, S.B., Tennyson, M.E., and Whidden, K.J., 2012, Assessment of undiscovered oil and gas resources of the Ordovician Utica Shale of the Appalachian Basin Province, 2012: U.S. Geological Survey Fact Sheet 2012-3116.

Klemic, Harry, 1962, Uranium occurrences in sedimentary rocks of Pennsylvania: U.S. Geological Survey Bulletin 1107-D, p. 243-288.

Kresse, T.M., Warner, N.R., Hays, P.D., Down, Adrian, Vengosh, Avner, and Jackson, R.B., 2012, Shallow groundwater quality and geochemistry in the Fayetteville Shale gas-production area, north-central Arkansas, 2011: U.S. Geological Survey Scientific Investigations Report 2012-5273, $31 \mathrm{p}$.
Langmuir, Donald, 1971, The geochemistry of some carbonate groundwaters in central Pennsylvania: Geochimica et Cosmochimica Acta, v. 35, p. 1023-1045.

Langmuir, Donald, 1997, Aqueous environmental geochemistry: Prentice Hall, New Jersey, 600 p.

Llewellyn, G.T., 2014, Evidence and mechanisms for Appalachian Basin brine migration into shallow aquifers in NE Pennsylvania, USA: Hydrogeology Journal, v. 22, p. 1055-1066.

Lohman, S.W., 1937, Groundwater in northeastern Pennsylvania: Pennsylvania Geological Survey, 4th series, Bulletin W4, 208 p.

Manning, D.A.C., 2008, Phosphate minerals, environmental pollution and sustainable agriculture: Elements, v. 4, p. $105-108$.

McCauley, J.F., 1961, Uranium in Pennsylvania: Pennsylvania Geological Survey, 4th series, Bulletin M3, 71 p.

McCleskey, R.B, Nordstrom, D.K., Ryan, J.N., and Ball, J.W., 2012, A new method of calculating electrical conductivity with applications to natural waters: Geochimica et Cosmochimica Acta, v. 77, p. 369-382.

McMahon, P.B, and Chapelle, F.H., 2008, Redox processes and water quality of selected principal aquifer systems: Ground Water, v. 46, p. 259-271.

Miles, C.E., and Whitefield, T.G., comps., 2001, Bedrock geology of Pennsylvania: Pennsylvania Geological Survey, 4th series, digital dataset, scale 1:250,000.

Mullaney, J.R., Lorenz, D.L., Arntson, A.D., 2009. Chloride in groundwater and surface water in areas underlain by the Glacial Aquifer System, northern United States: U.S. Geological Survey Scientific Investigations Report 2009-5086, 41 p.

National Atmospheric Deposition Program, 2016, Annual trend plots for NTN site PA72 (Milford, Pennsylvania) accessed May 18, 2016, at http://nadp.sws.uiuc.edu/data/ ntn/plots/ntntrends.html?siteID=PA72.

National Oceanic and Atmospheric Administration, 2015, Climate Data Online Annual Summaries, Annual Climatological Summary 2013 and 2014 for stations COOP: 367029_Pleasant Mount 1 W, PA US and COOP:363758Hawley 1 E, PA US, accessed October 7, 2015, at http:// www.ncdc.noaa.gov/cdo-web/datasets\#ANNUAL. 
Parkhurst, D.L., and Appelo, C.A.J., 2013, Description of input and examples for PHREEQC version 3-A computer program for speciation, batch-reaction, one-dimensional transport, and inverse geochemical calculations: U.S. Geological Survey Techniques and Methods 6-A43, 497 p.

Pennsylvania Department of Environmental Protection, 2012, PA-DEP Recommended Basic Oil \& Gas Pre-Drill Parameters: Factsheet 8000-FS-DEP4300, Rev. November 2012.

Pennsylvania Department of Environmental Protection, 2014a, Wells drilled by county, accessed January 28, 2014, at http:// www.depreportingservices.state.pa.us/ReportServer/Pages/ ReportViewer.aspx?/Oil_Gas/Wells_Drilled_By_County.

Pennsylvania Department of Environmental Protection, 2014 b, Year to date permits issued by well type, accessed January 28, 2014, at http://www.depreportingservices.state. pa.us/ReportServer/Pages/ReportViewer.aspx?/Oil_Gas/ Permits_Issued_Count_by_Well_Type_YTD.

Pennsylvania Department of Environmental Protection, 2014c, PA-DEP Recommended Basic Oil and Gas Pre-Drill Parameters, revised April 2014, accessed July 18, 2014, at http://www.elibrary.dep.state.pa.us/dsweb/Get/Document100259/8000-FS-DEP4300.pdf.

Pennsylvania Department of Environmental Protection, Office of Oil and Gas Management, 2015a, Spud Data accessed September 29, 2015, at http://www.depreportingservices. state.pa.us/ReportServer/Pages/ReportViewer.aspx?/ Oil_Gas/Spud_External_Data.

Pennsylvania Department of Environmental Protection, Office of Oil and Gas management, 2015b, Wells drilled by County, accessed September 29, 2015, at http:/www. depreportingservices.state.pa.us/ReportServer/Pages/ ReportViewer.aspx?/Oil_Gas/Wells_Drilled_By_County.

Peters, N.E., and Bonelli, J.E., 1982, Chemical composition of bulk precipitation in the north-central and northeastern United States, December 1980 through February 1981: U.S. Geological Survey Circular 874, 63 p.

Pirc, Simon, and Rose, A.W., 1981, Uranium anomalies in paleo-aquifers near sandstone-type deposits in the Devonian Catskill Formation of Pennsylvania: Journal of Geochemical Exploration v. 15, p. 219-231.

Poth, C.W., 1962, The occurrence of brine in western Pennsylvania: Pennsylvania Geological Survey, 4th ser., Mineral Resources Report 47.
Poth, Charles W., 1963. Geology and hydroology of the Mercer Quadrangle, Mercer, Lawrence, and Butler Counties, Pennsylvania: Pennsylvania Geologic Survey Water Resource Report 16, 149 p.

P-STAT, Inc., 2008, P-STAT Version 2.23 Release 11, May 2008. Hopewell, N.J., P-STAT, Inc.

Reilly, D., Singer, D., Jefferson, A., and Eckstein, Y., 2015, Identification of local groundwater pollution in northeastern Pennsylvania: Marcellus flowback or not?: Environmental Earth Sciences, v. 73 no.12, p. 8097-8109.

Reese, S.O., Neboga, V.V., Pelepko, Seth, Kosmer, W.J., and Beattie, Stewart, 2014, Groundwater and petroleum resources of Sullivan County, Pennsylvania: Pennsylvania Geological Survey, 4th series, Water Resource Report 71, 99 p., 6 pls., 27 p. appendix

Révész, K.M., Breen, K.J., Baldassare, A.J., and Burruss, R.C., 2012, Carbon and hydrogen isotopic evidence for the origin of combustible gases in water-supply wells in northcentral Pennsylvania: Applied Geochemistry, 2010, v. 25, p. 1845-1859. Erratum: Applied Geochemistry, 2012, v. 27, p. $361-375$.

Rhodes, A.L., and Horton, N.J., 2015, Establishing baseline water quality for household wells within the Marcellus Shale gas region, Susquehanna County, Pennsylvania, U.S.A.: Applied Geochemistry, accessed at http://dx.doi. org/10.1016/j.apgeochem.2015.03.004.

SAS Institute Inc., 2012, SAS 9.4 for Windows: Cary, N.C. SAS Institute, Inc.

Schoell, M., 1980, The hydrogen and carbon isotopic composition of methane from natural gases of various origins: Geochimica et Cosmochimica Acta, v. 44, p. 649-661.

Senior, L.A., 2014, A reconnaissance spatial and temporal assessment of methane and inorganic constituents in groundwater in bedrock aquifers, Pike County, Pennsylvania, 2012-13: U.S. Geological Survey Scientific Investigations Report 2014-5117, 91 p.

Sevon, W.D., 1975, Geology and mineral resources of the Tobyhanna and Buck Hill Falls quadrangles, Monroe County, Pennsylvania: Pennsylvania Geological Survey, 4th series, Atlas 204ab, 2 pls.

Sevon, W.D., Berg, T.M., Schultz, L.D., and Crowl, G.H., 1989, Geology and mineral resources of Pike County, Pennsylvania: Pennsylvania Geological Survey, 4th Series, County Report 65, 141 p., 2 pls. 
Sevon, W.D., 2000, Physiographic provinces of Pennsylvania: Pennsylvania Geological Survey, 4th series, Map 13, 1 sheet.

Siegel, D.I., Smith, B., Perry, E., Bothun, R., and Hollingsworth, M., 2015, Pre-drilling water-quality data of groundwater prior to shale gas drilling in the Appalachian Basin: Analysis of the Chesapeake Energy Corporation dataset: Applied Geochemistry, v. 63, p. 37-57.

Sloto, R.A., 2013, Baseline groundwater quality from 20 domestic wells in Sullivan County, Pennsylvania, 2012: U.S. Geological Survey Scientific Investigations Report 2013-5085, 27 p.

Sloto, R.A., 2014, Baseline groundwater quality from 34 wells in Wayne County, Pennsylvania, 2011 and 2013: U.S. Geological Survey Open-File Report 2014-1116, 24 p.

Snoeyink, V.L., and Jenkins, D., 1981, Water chemistry: New York, John-Wiley \& Sons, 463 p.

Stumm, Werner, and Morgan, J.J., 1996, Aquatic chemistrychemical equilibria and rates in natural waters (3rd): New York, Wiley-Interscience, $1022 \mathrm{p}$.

Taylor, L.E., 1984, Groundwater resources of the upper Susquehanna River Basin, Pennsylvania: Pennsylvania Geological Survey, 4th series, Water Resource Report 58, $136 \mathrm{p}$.

Taylor, S.W., Lollar, B.S., and Wassenaar, L.I., 2000, Bacteriogenic ethane in near-surface aquifers: Implications for leaking hydrocarbon well bores: Environmental Science \& Technology, v. 34, p. 4727-4732.

Thyne, Geoffrey, Guler, Cuneyt, and Porter, Eileen, 2004, Sequential analysis of hydrochemical data for watershed characterization: Ground Water, v. 42, p. 711-723.
U.S. Census Bureau, 2014, Annual estimates of the resident population: April 1, 2010 to July 1, 2013, accessed March 31, 2014, at http://factfinder2.census.gov/faces/tableservices/jsf/pages/productview.xhtml? src=bkmk.

U.S. Environmental Protection Agency, 2001, Ambient water quality criteria recommendations information supporting the development of state and Tribal nutrient criteria rivers and streams in Nutrient Ecoregion VIII: U.S. Environmental Protection Agency EPA-822-B-01-015, accessed April 11, 2016, at https:/www.epa.gov/sites/production/files/documents/rivers8.pdf.

U.S. Environmental Protection Agency, 2012, 2012 Edition of the drinking water standards and health advisories: U.S. Environmental Protection Agency EPA 822-S-12-001, accessed June 10, 2014, at http://water.epa.gov/action/advisories/drinking/upload/dwstandards2012.pdf.

U.S. Environmental Protection Agency, 2014, Natural gas extraction-hydraulic fracturing, accessed February 12, 2014, at http://water.epa.gov/type/groundwater/uic/class2/ hydraulicfracturing/.

U.S. Geological Survey, variously dated, National field manual for the collection of water-quality data: U.S. Geological Survey Techniques of Water-Resources Investigations, book 9, chap. A1-A9, accessed December 5, 2012, at http://pubs. water.usgs.gov/twri9A/.

U.S. Geological Survey, 2014a, National Water Quality Laboratory, accessed February 11, 2014, at http://nwql.usgs. gov/.

U.S. Geological Survey, 2014b, USGS water data for Pennsylvania, accessed February 11, 2014, at http://waterdata.usgs.gov/pa/nwis/nwis. 
Velleman, P.F., and Hoaglin, D., 1981, Applications, basics, and computing of exploratory data analysis: Boston, Mass., Duxbury Press, 354 p.

Warner, N.R., Jackson, R.B., Darrah, T.H., Osborn, S.G., Down, Adrian, Zhao, Kaiguang, White, Alissa, and Vengosh, Avner, 2012, Geochemical evidence for possible natural migration of Marcellus Formation brine to shallow aquifers in Pennsylvania: Proceedings of the National Academy of Sciences, v. 109, no. 30, p. 11961-11966.

Wayne County Planning Commission, 2010, Wayne County comprehensive plan update, accessed October 28, 2013, at http://planning.co.wayne.pa.us/resource-materials/ wayne-county-comprehensive-plan-update/.

Welch, A.H., Westjohn, D.B., Helsel, D.R., and Wanty, R.B., 2000, Arsenic in ground water of the United StatesOccurrence and geochemistry: Ground Water, v. 38, p. 589-604.

White, I.C., 1881, The geology of Susquehanna County and Wayne County: Pennsylvania Geological Survey, 2nd series, Report G5, 243 p.

Whittemore, D.O., 1995, Geochemical differentiation of oil and gas brine from other saltwater sources contaminating water resources: case studies from Kansas and Oklahoma: Environmental Geoscience, v. 2, p. 15-31.

Whittemore, D.O., 2007, Fate and identification of oil-brine contamination in different hydrogeologic settings: Applied Geochemistry, v. 22, p. 2099-2114.

Wilson, B., 2014. Geologic and baseline groundwater evidence for naturally occurring, shallowly sourced, thermogenic gas in northeastern Pennsylvania: American Association of Petroleum Geologists Bulletin, v. 98, p. 37 
Table 10. Location, depth, and construction characteristics for 89 wells sampled in Wayne County, Pennsylvania, July-September 2014.

[USGS, U.S. Geological Survey; DDMMSS.S, degrees, minutes, seconds; --, no data; NAD 83, North American Datum 1983; NAVD 88, North American Vertical Datum 1988; Geologic units: Dck, Catskill Formation; Dcpp, Poplar Gap and Packerton Members of Catskill Formation, undivided; Dclw, Long Run and Walcksville Members of Catskill Formation, undivided; Ded, Duncannon Member of Catskill Formation; Dcpg, Poplar Gap Member of Catskill Formation]

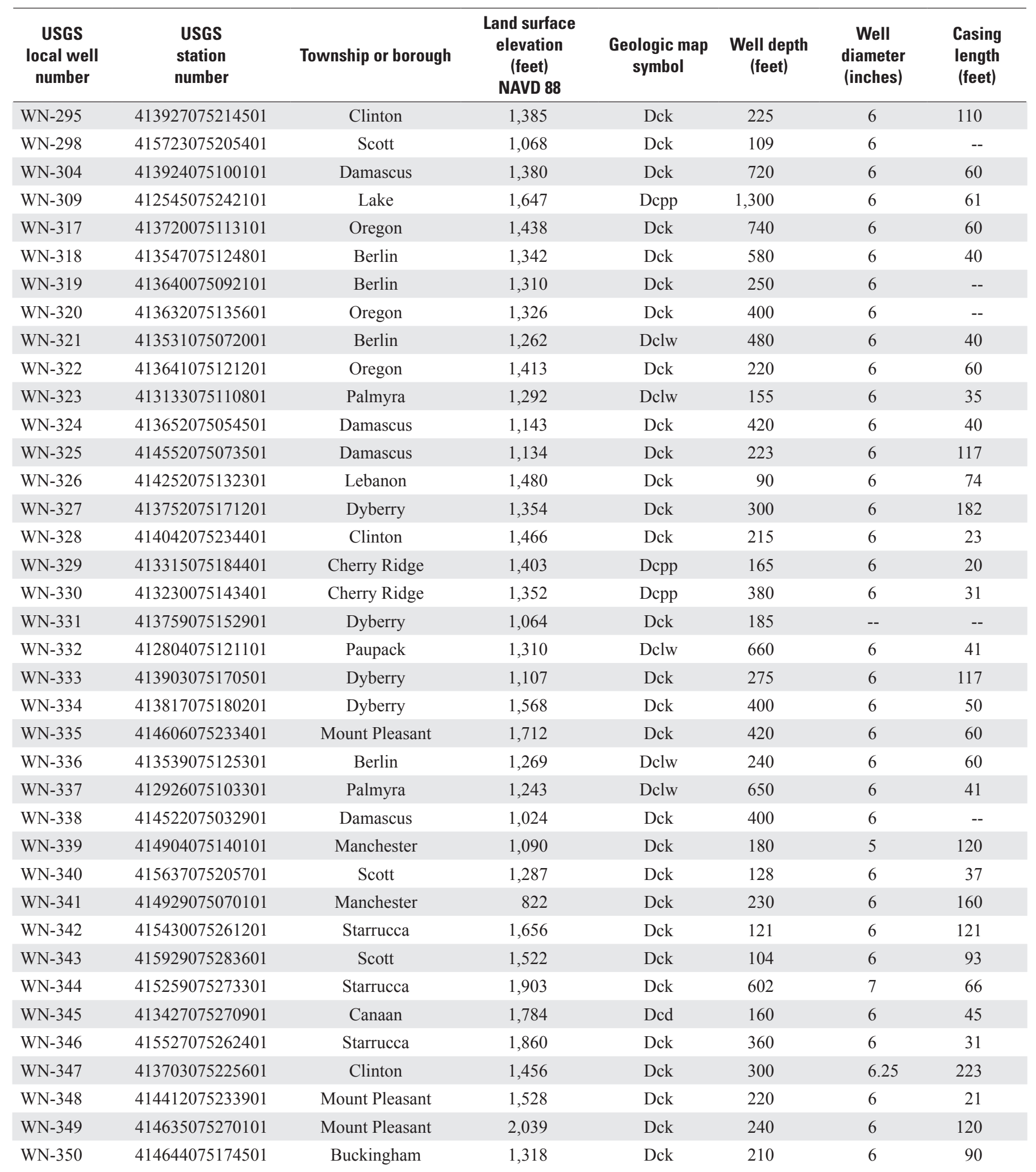


Table 10. Location, depth, and construction characteristics for 89 wells sampled in Wayne County, Pennsylvania, July-September 2014.-Continued

[USGS, U.S. Geological Survey; DDMMSS.S, degrees, minutes, seconds; --, no data; NAD 83, North American Datum 1983; NAVD 88, North American Vertical Datum 1988; Geologic units: Dck, Catskill Formation; Dcpp, Poplar Gap and Packerton Members of Catskill Formation, undivided; Dclw, Long Run and Walcksville Members of Catskill Formation, undivided; Ded, Duncannon Member of Catskill Formation; Dcpg, Poplar Gap Member of Catskill Formation]

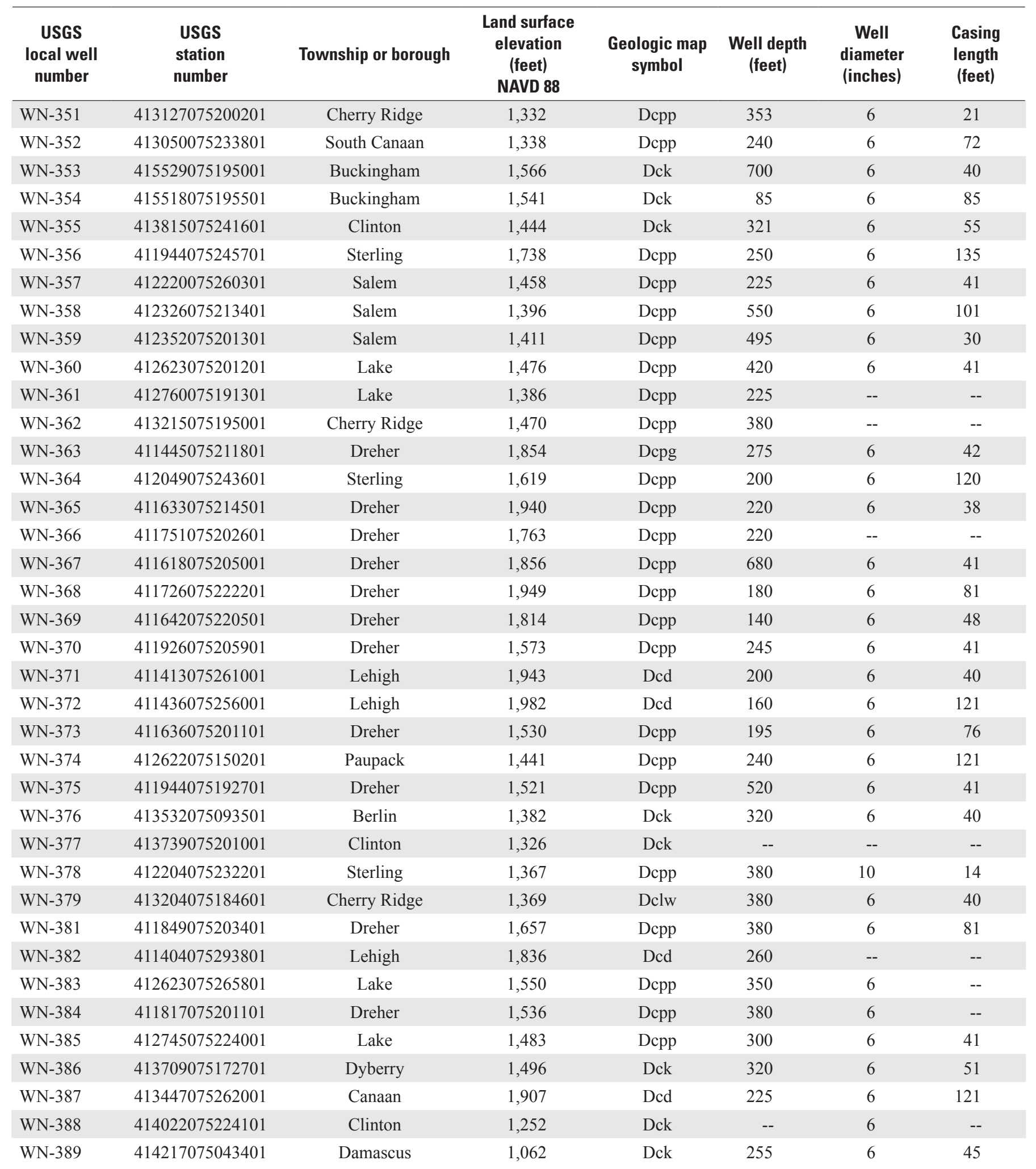


Table 10. Location, depth, and construction characteristics for 89 wells sampled in Wayne County, Pennsylvania, July-September 2014.-Continued

[USGS, U.S. Geological Survey; DDMMSS.S, degrees, minutes, seconds; --, no data; NAD 83, North American Datum 1983; NAVD 88, North American Vertical Datum 1988; Geologic units: Dck, Catskill Formation; Dcpp, Poplar Gap and Packerton Members of Catskill Formation, undivided; Dclw, Long Run and Walcksville Members of Catskill Formation, undivided; Dcd, Duncannon Member of Catskill Formation; Depg, Poplar Gap Member of Catskill Formation]

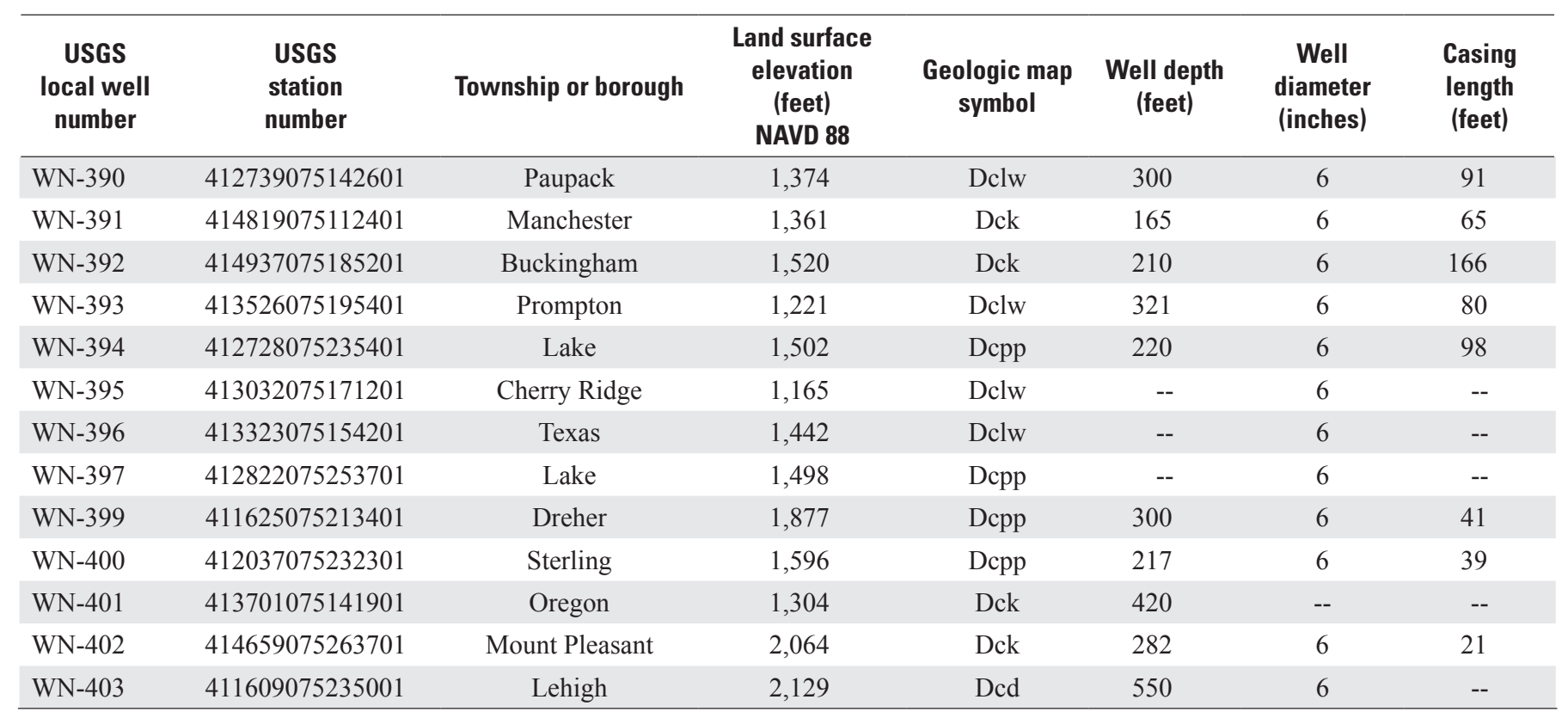




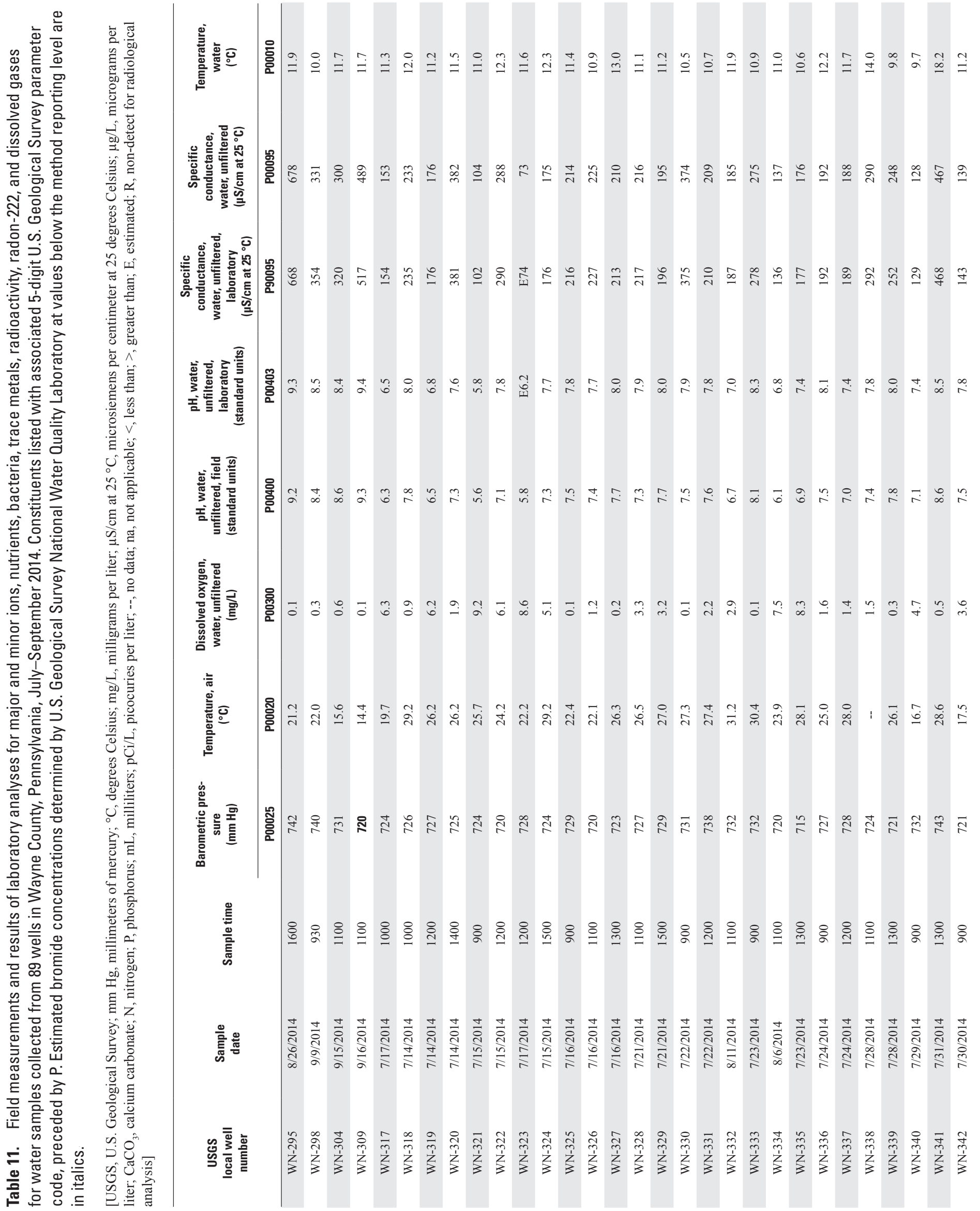




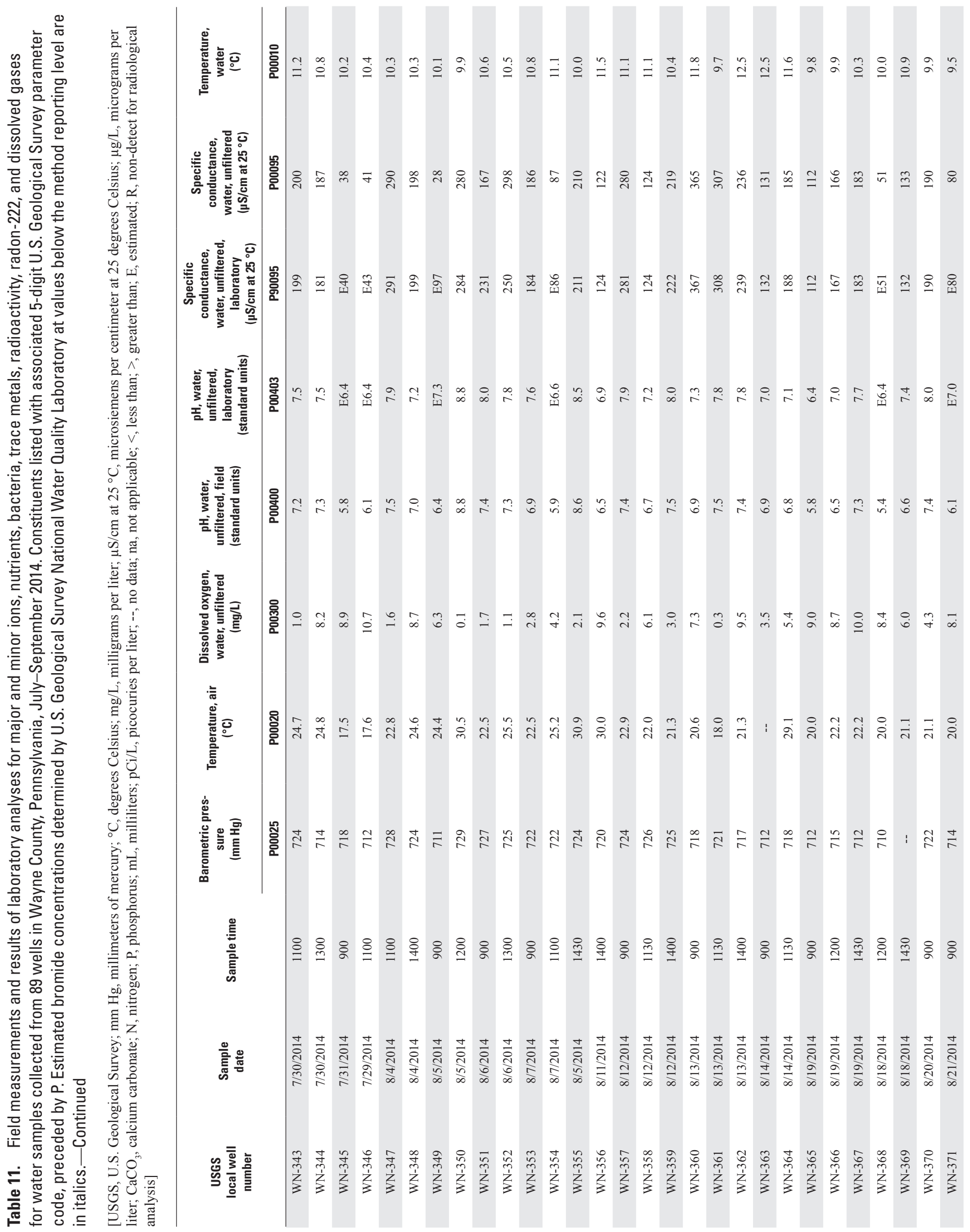




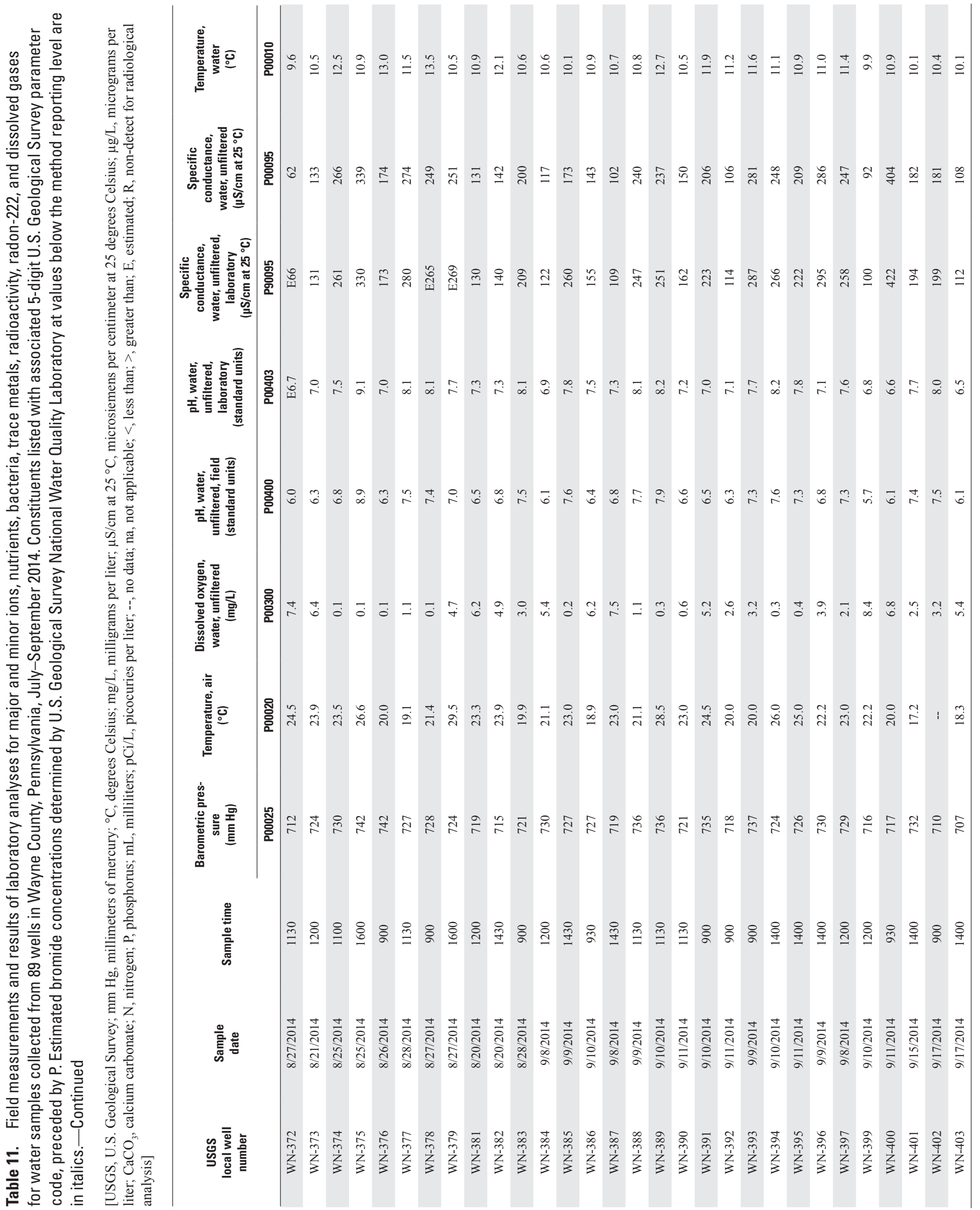




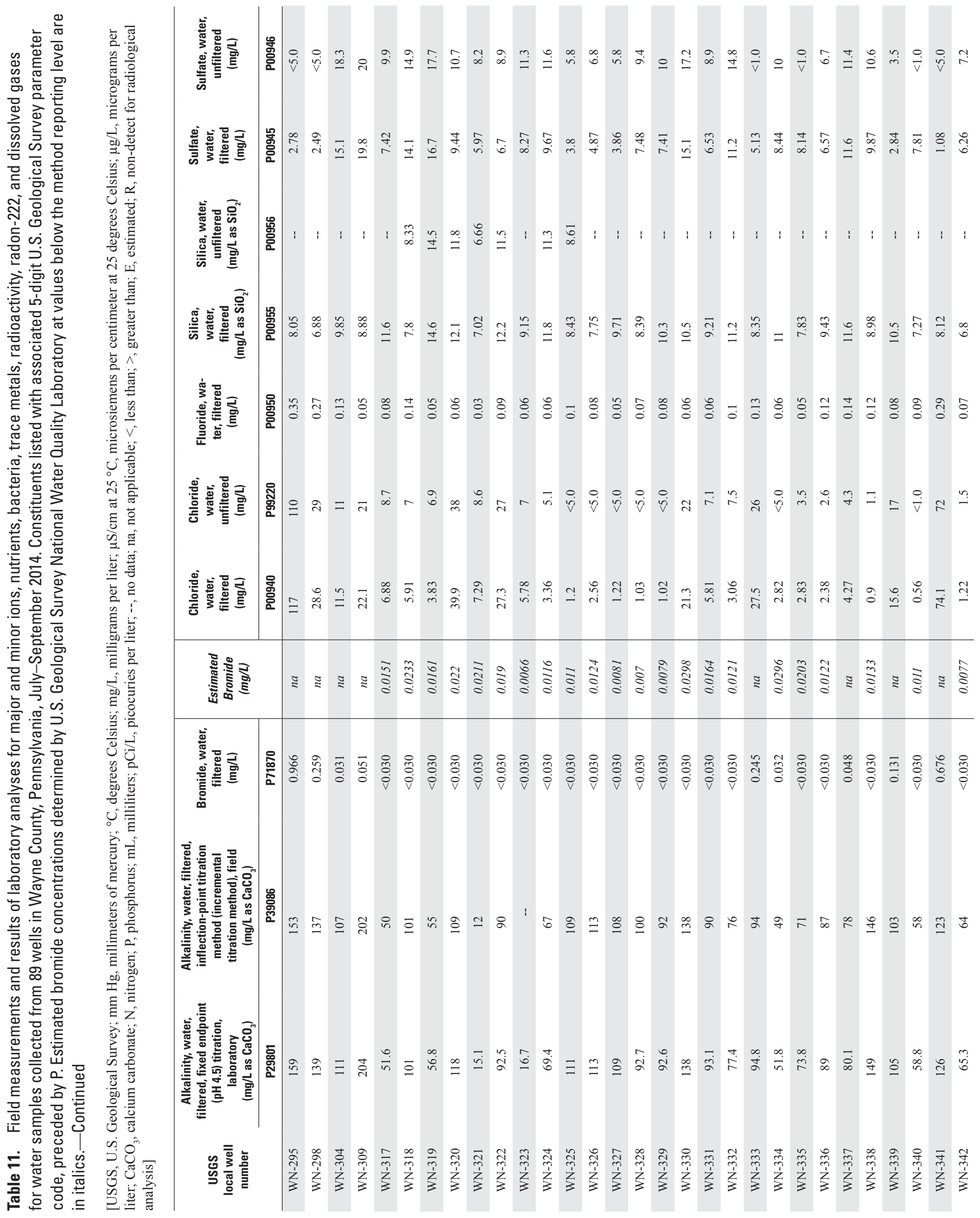




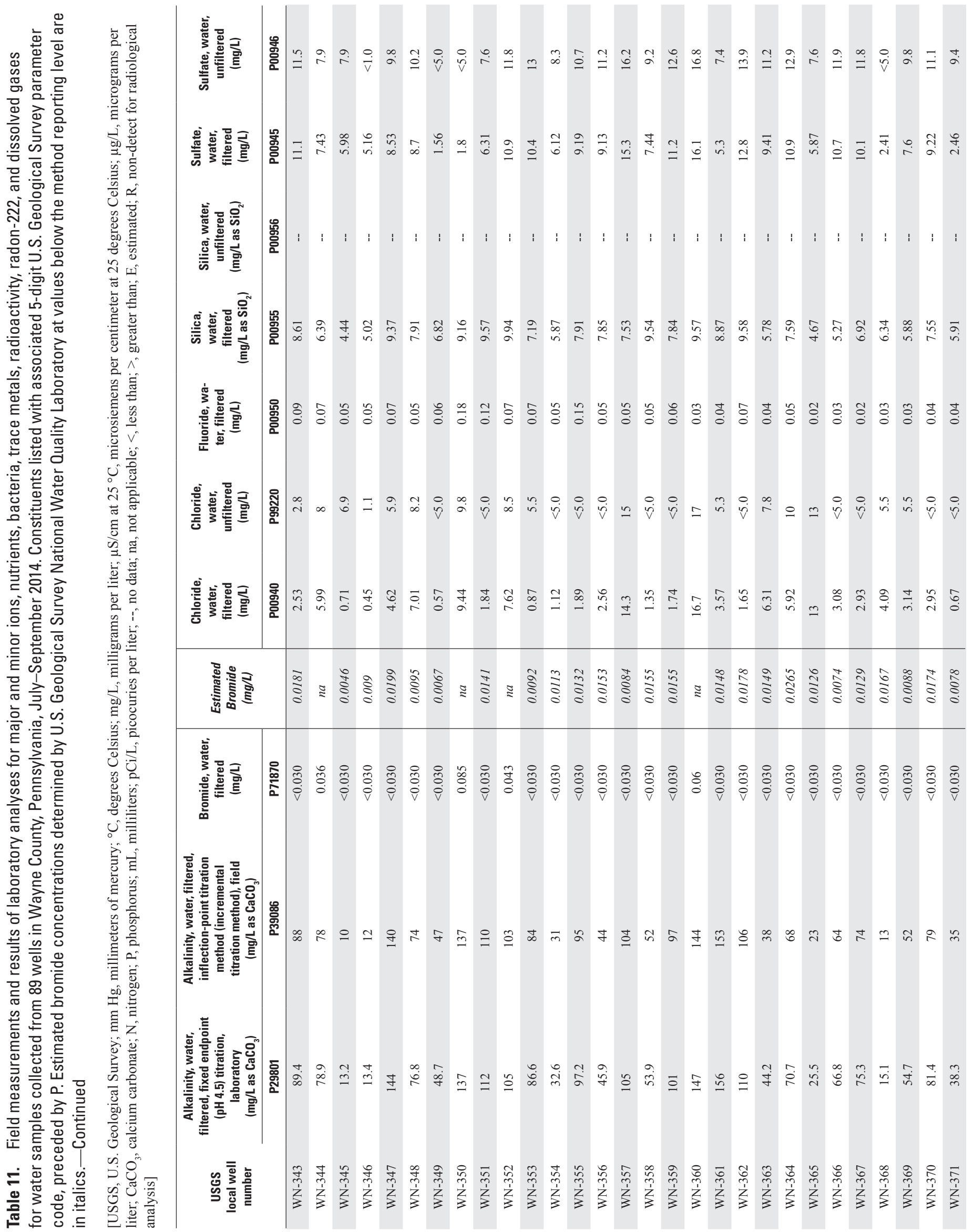




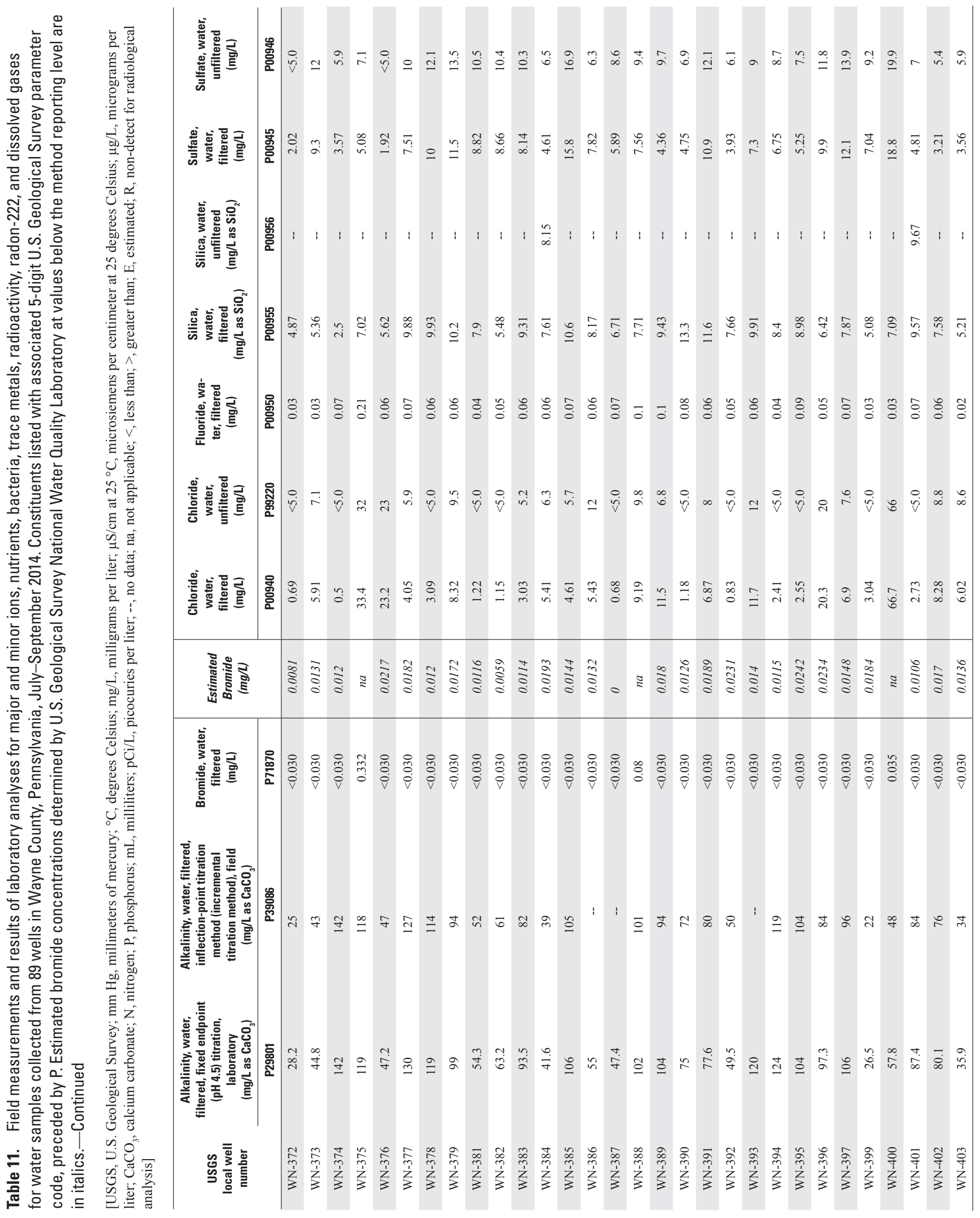




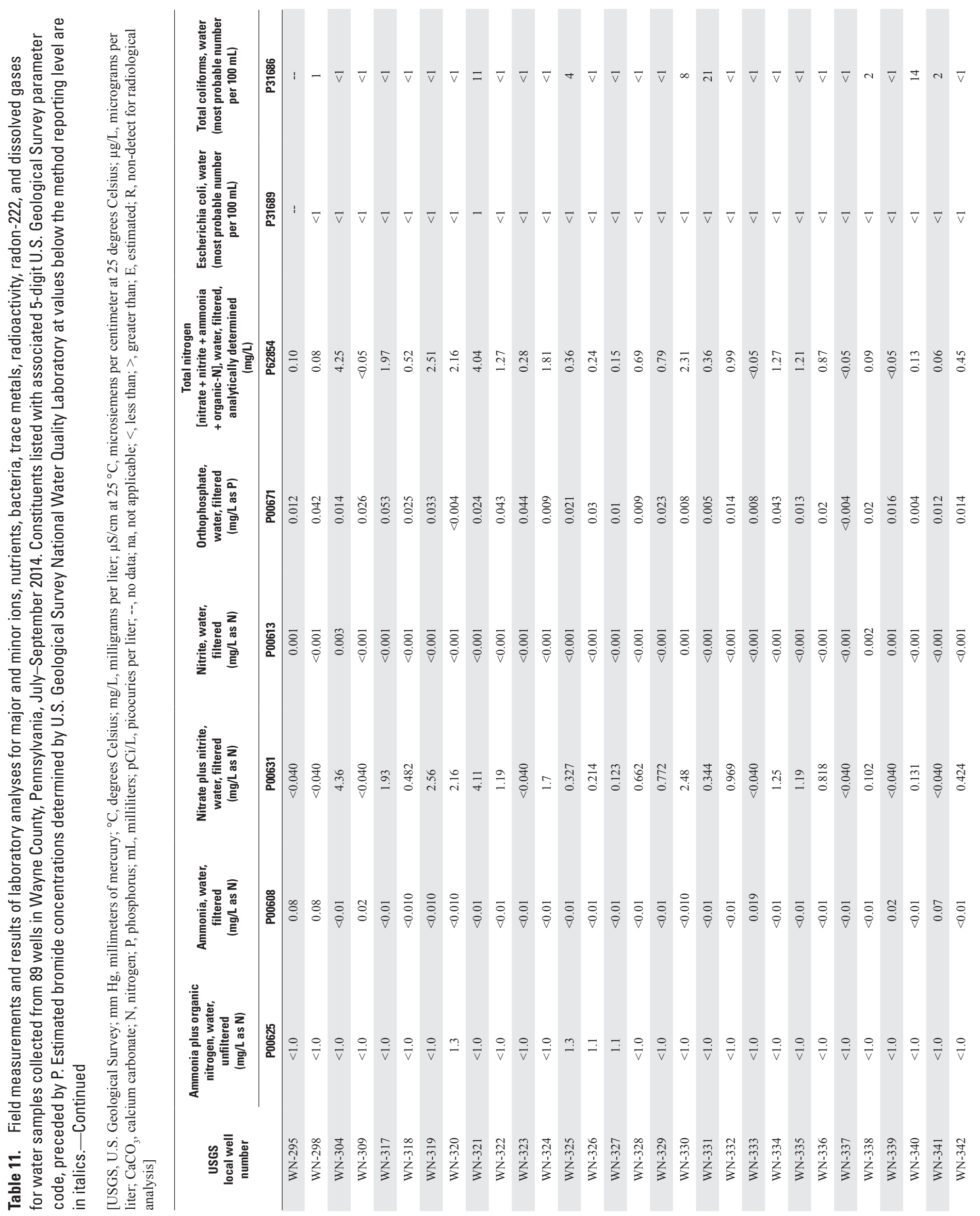




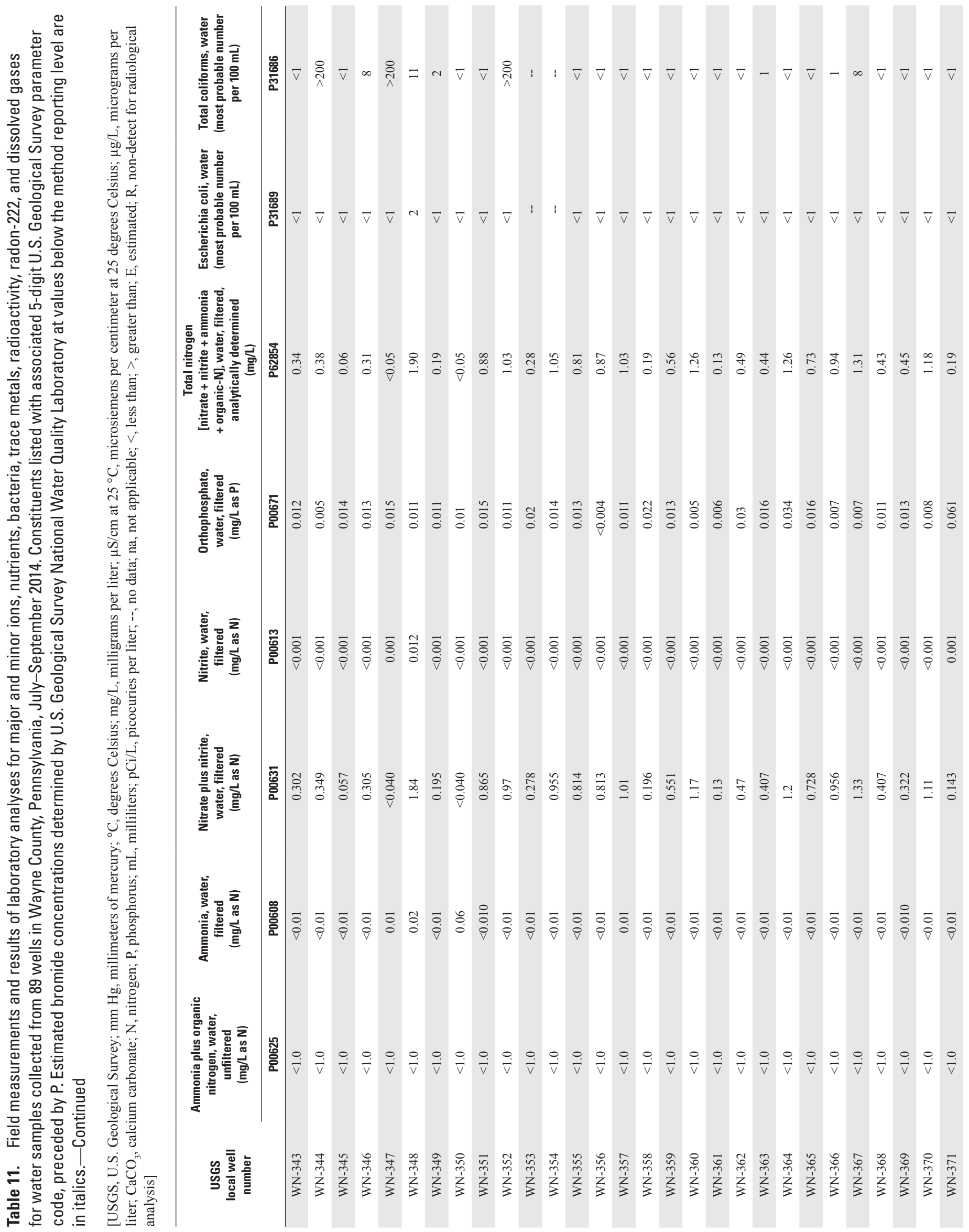




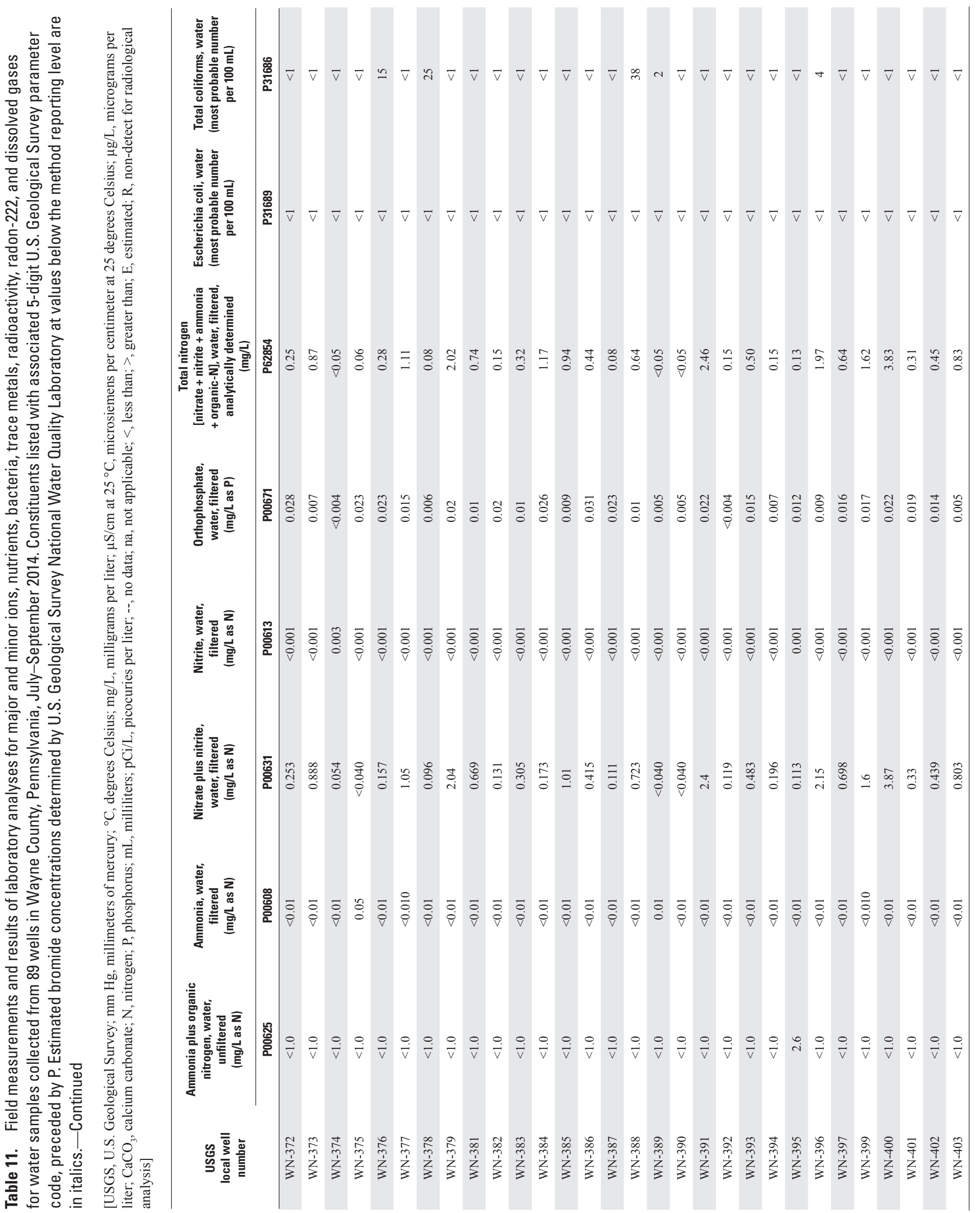




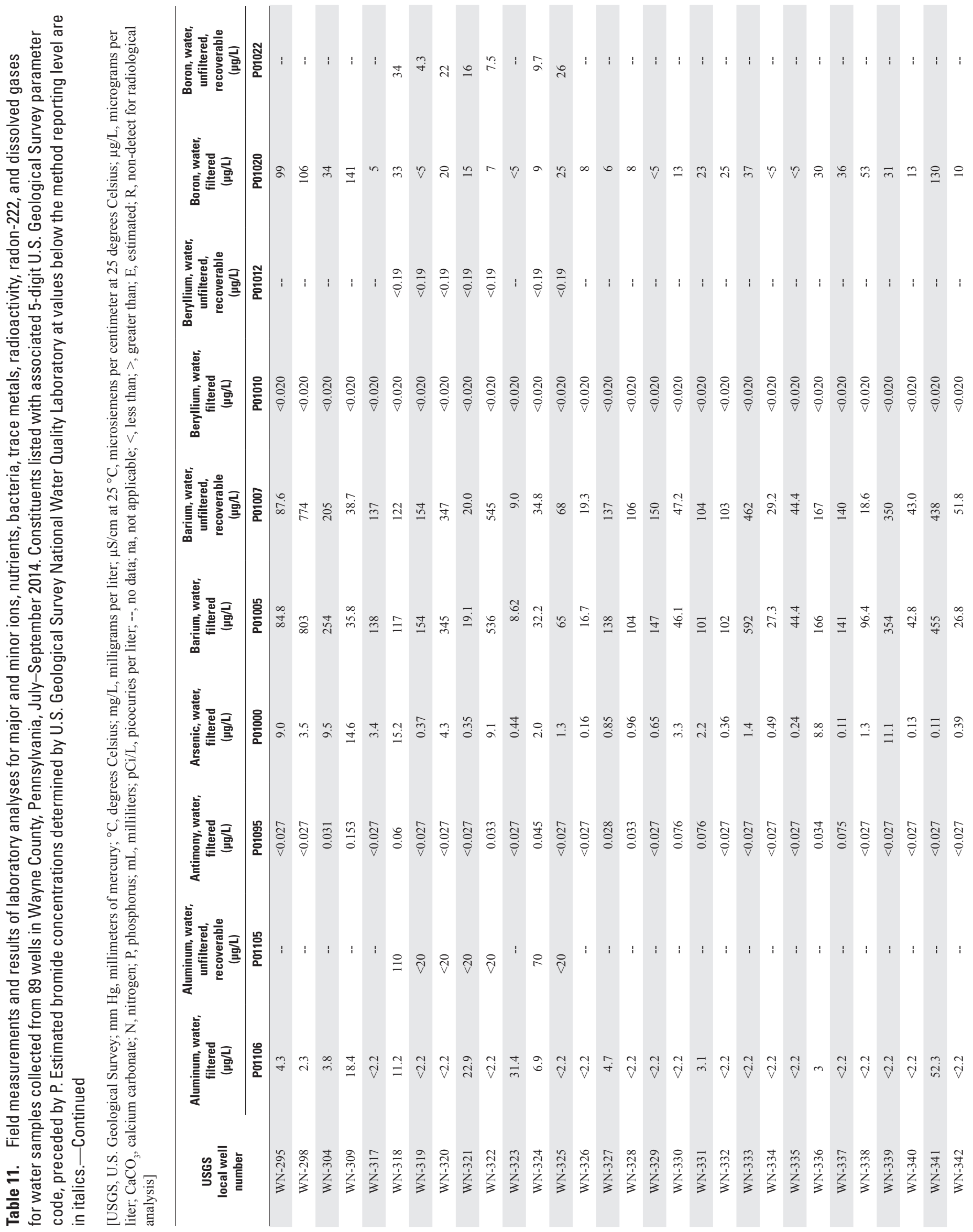




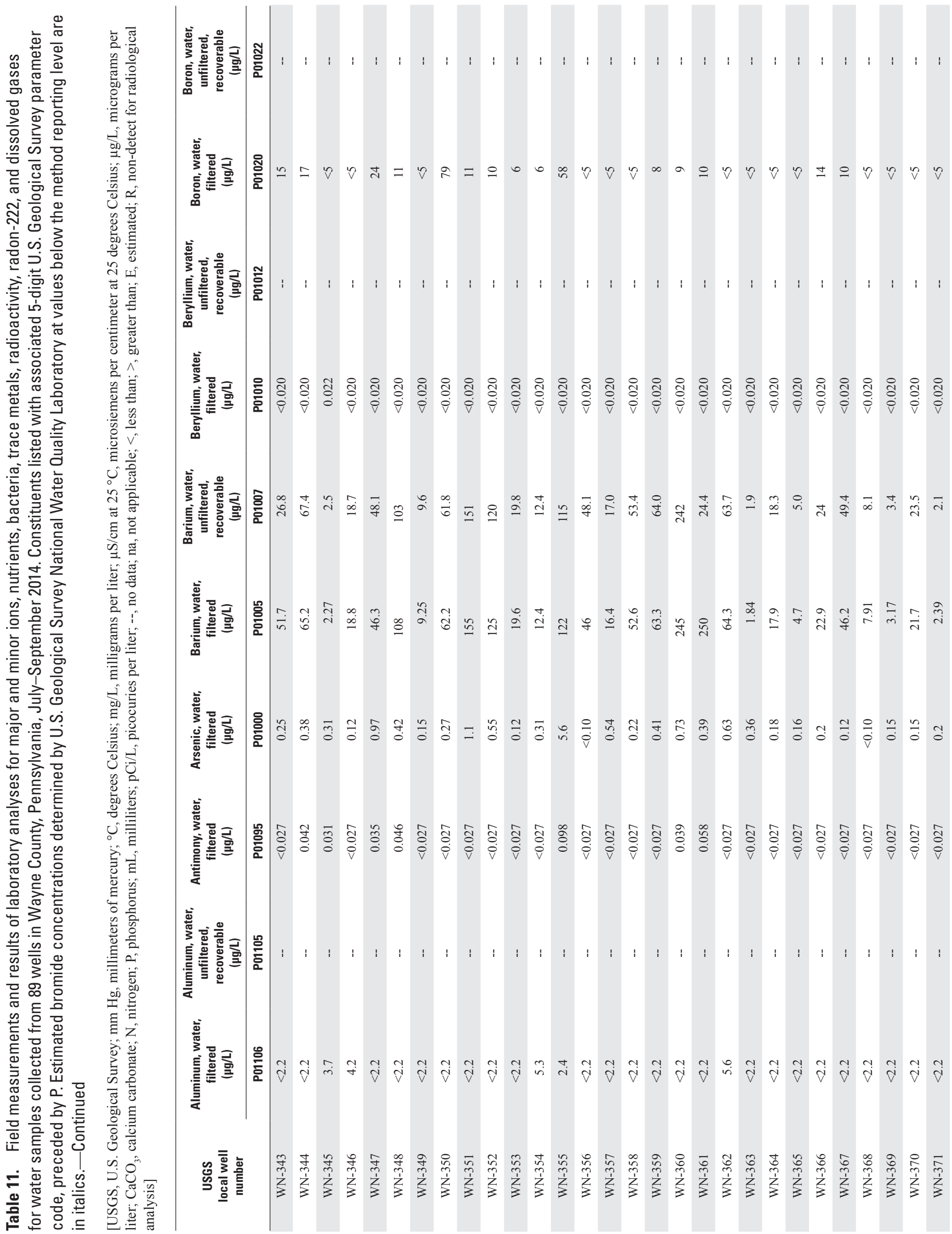




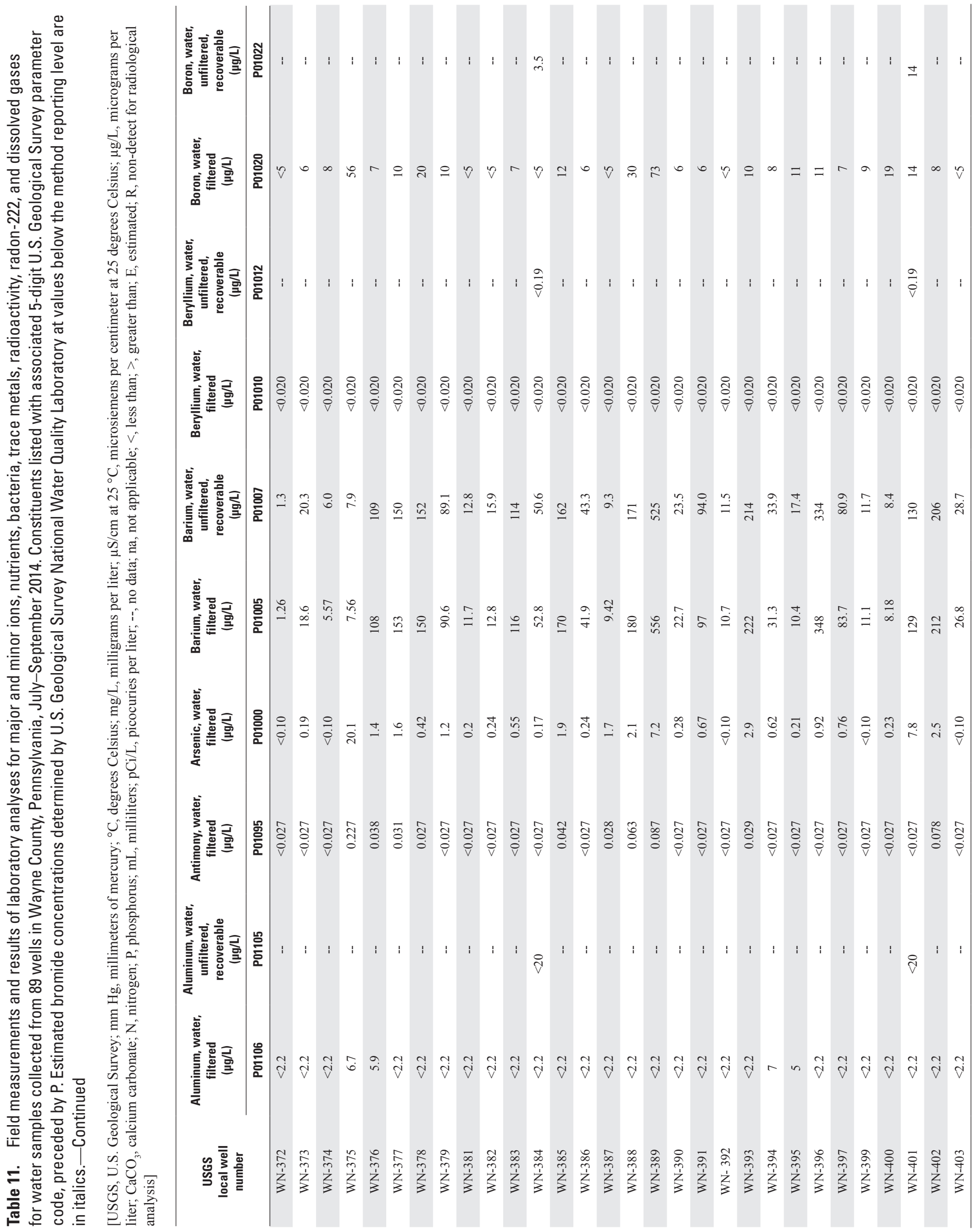




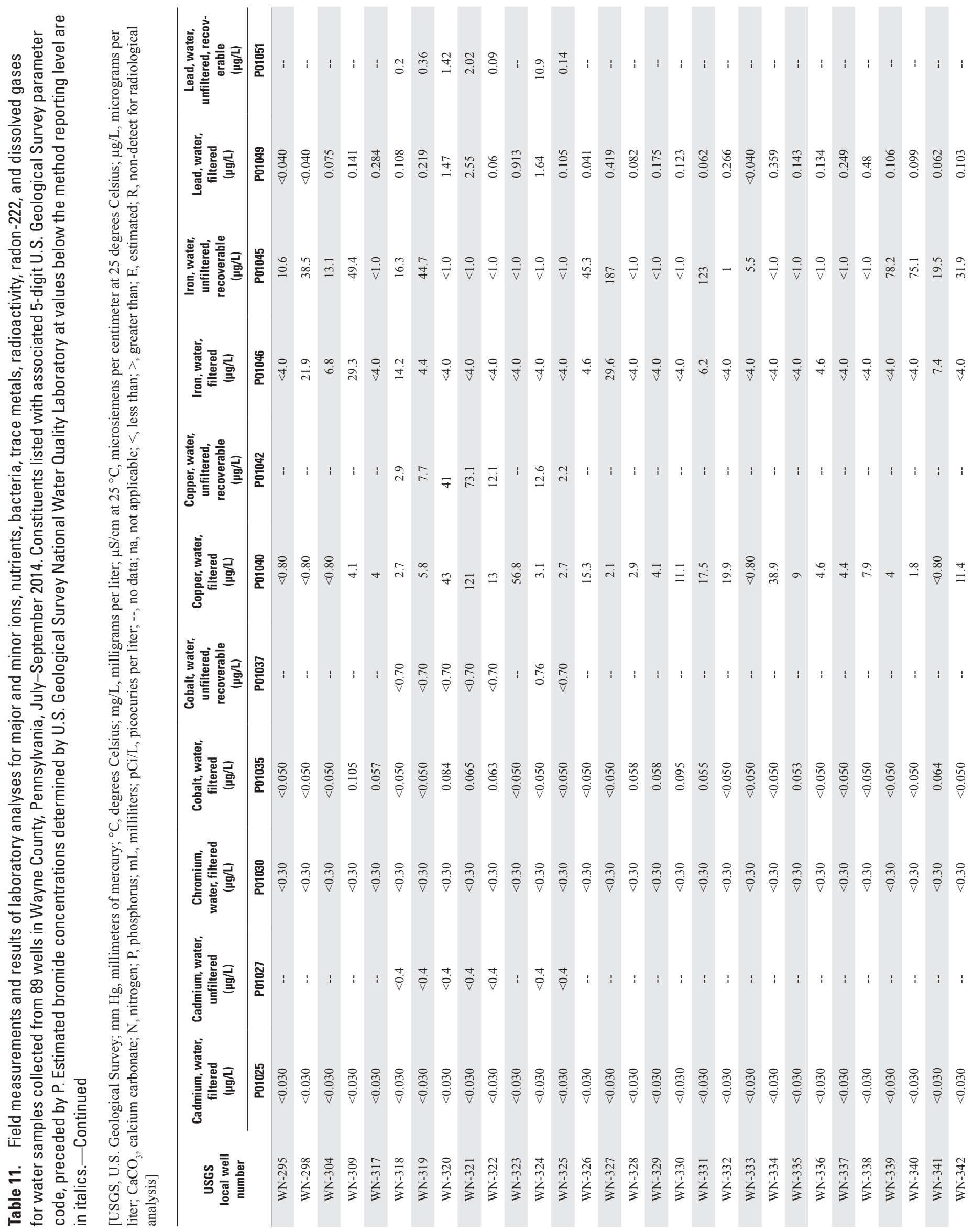




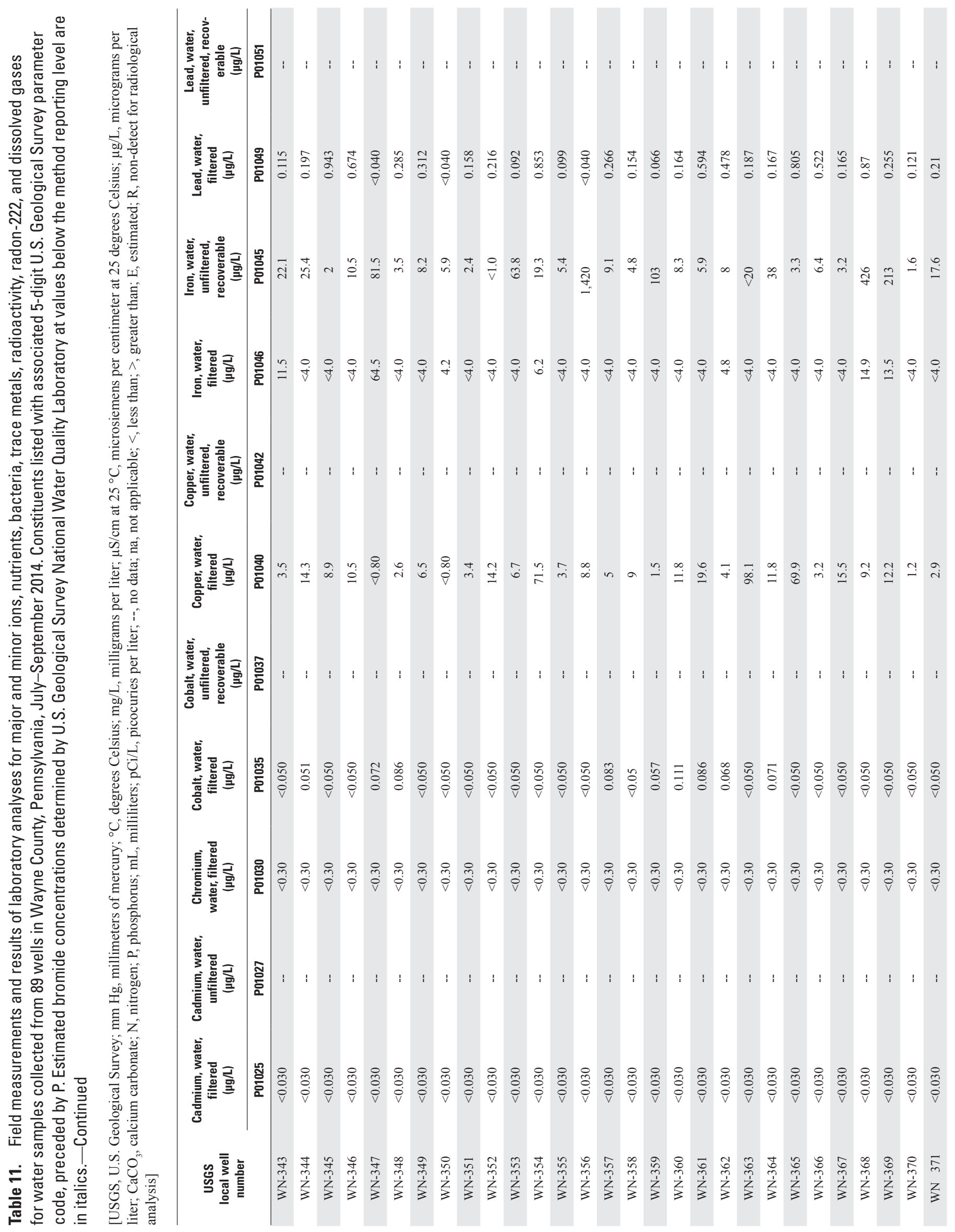




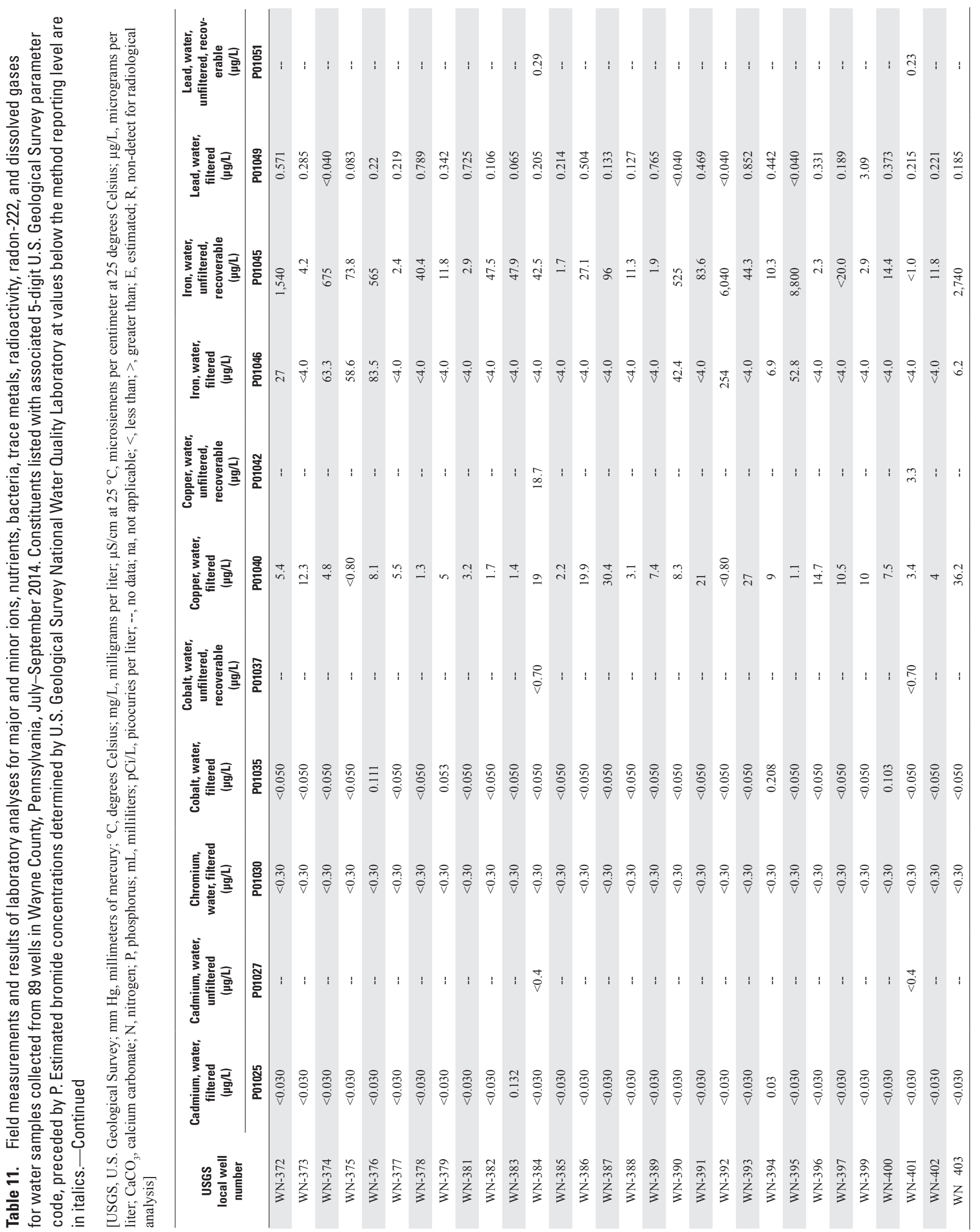




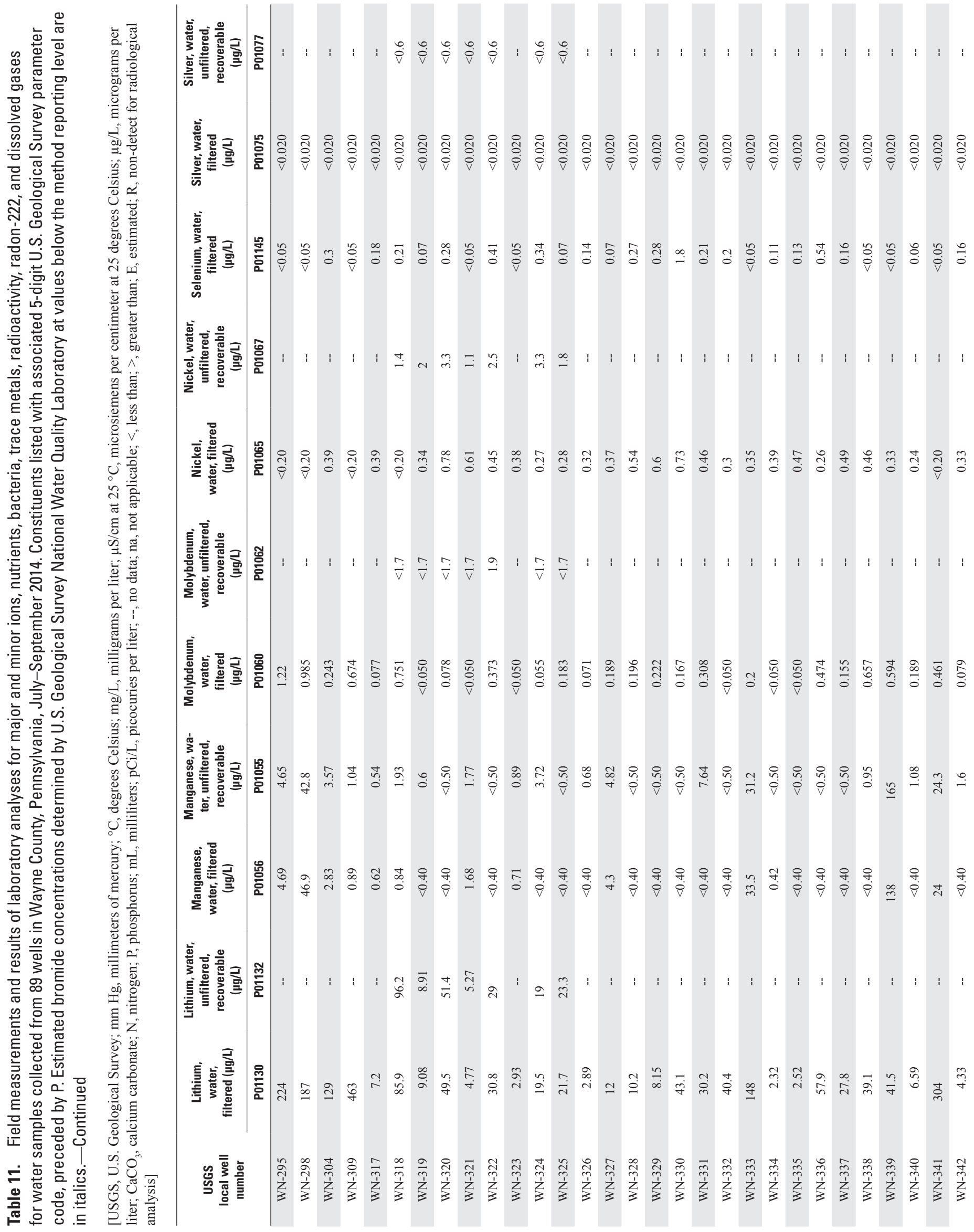




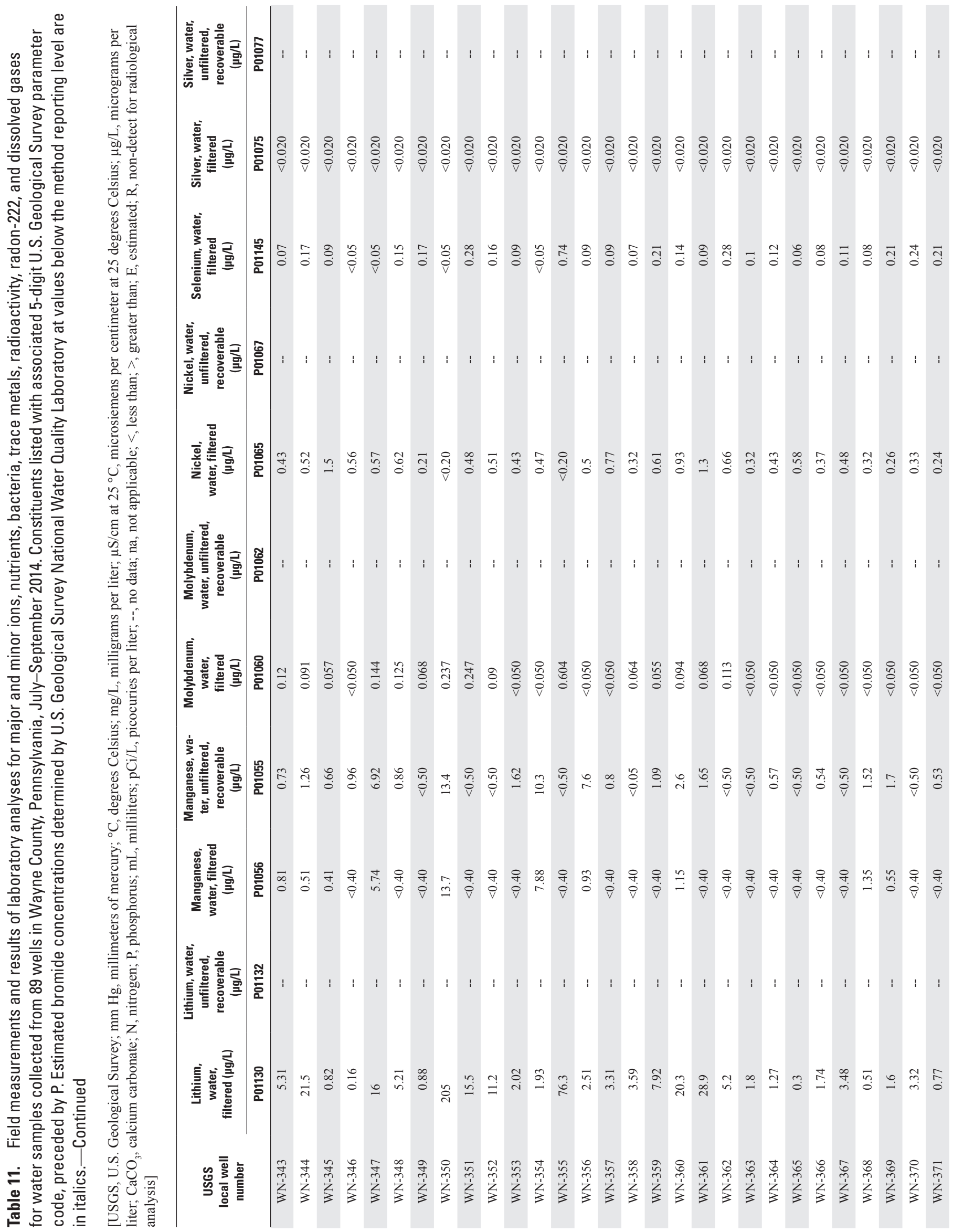




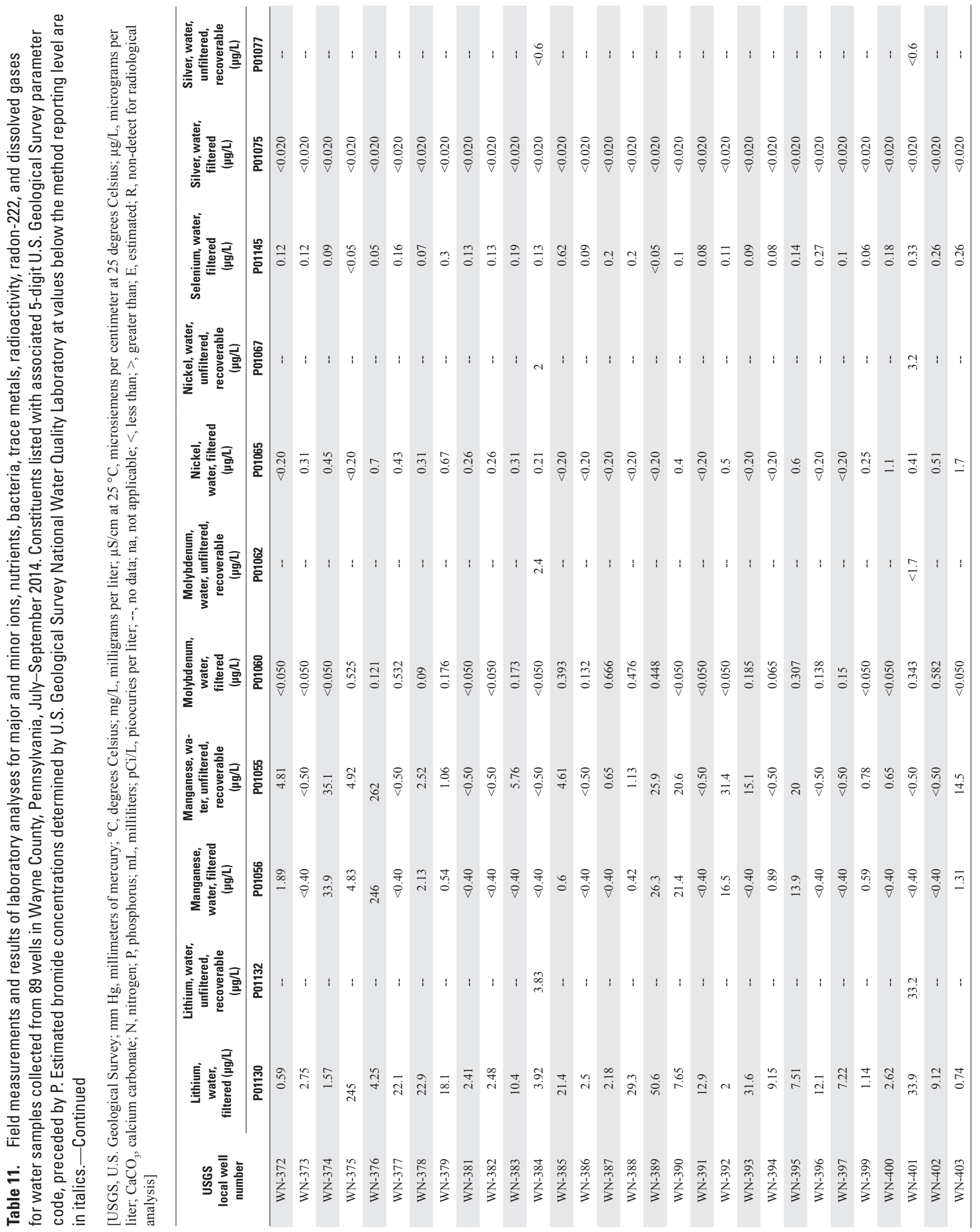




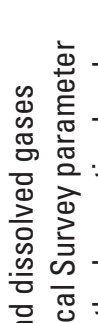

它 $\frac{\pi}{0}$

สิ 응

¿

흥 하 음

긴

蒙告

공

呵

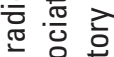

का क्ष

핑

表

Ð 3

苛苾

䨔

焉

要 卷

s⿱⺈.

可 0

旁完

它高 站

은

言 苍.

등 青

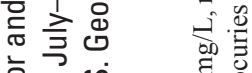

.흘

ह 진

흥

感充

믕

할

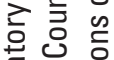

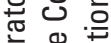

흥

중

응

壱

ఖ

응 잉

元

올 은 뭉

힝

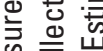

क

है

흥 흥형

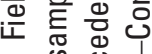

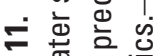

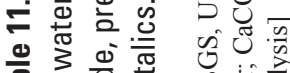

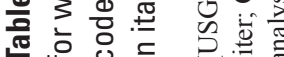

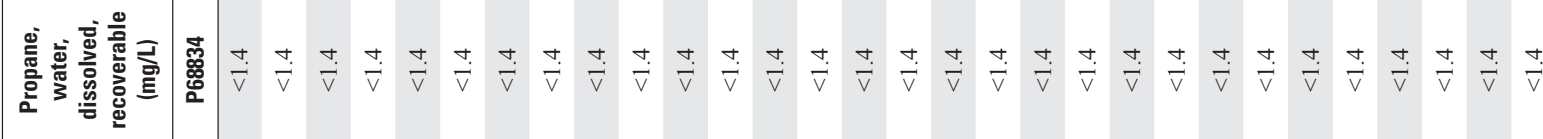

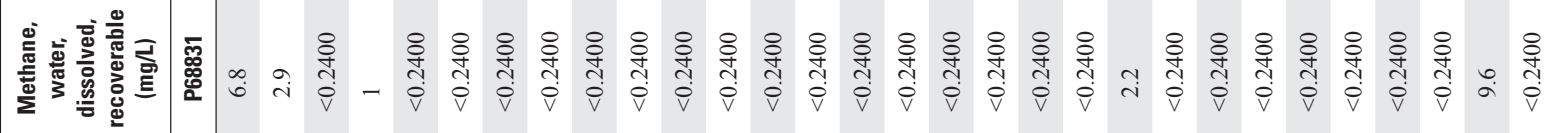

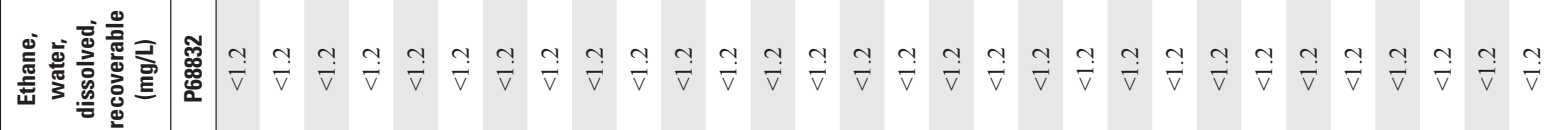

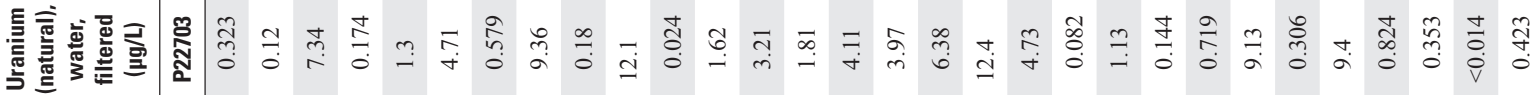

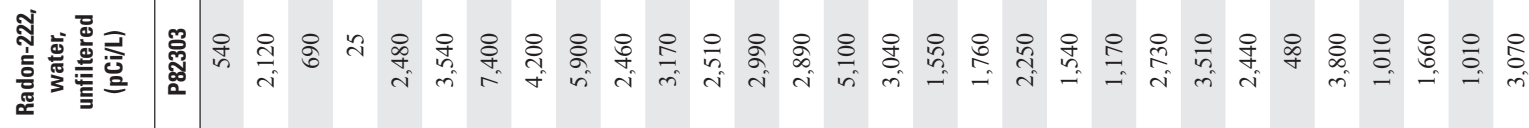

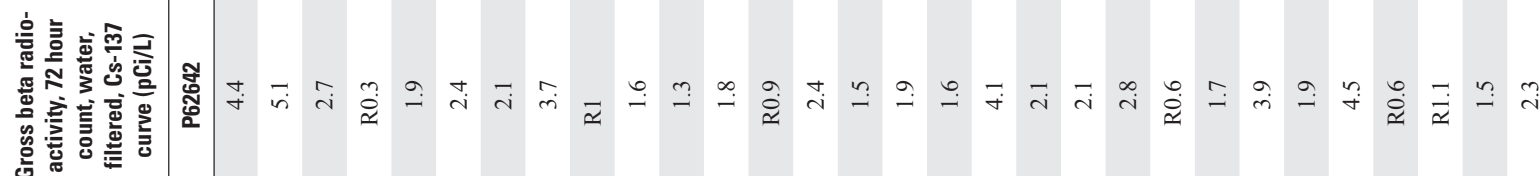

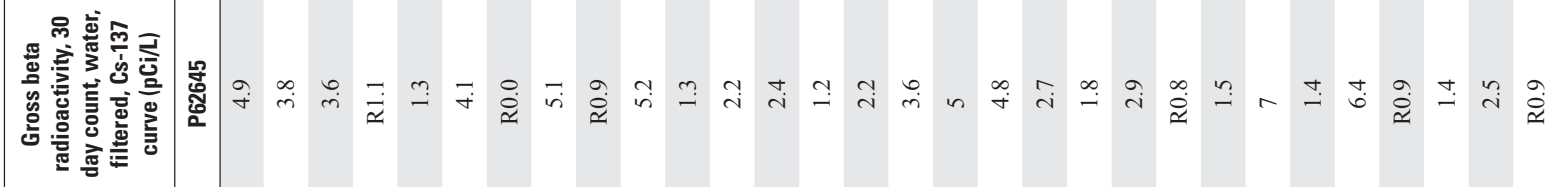

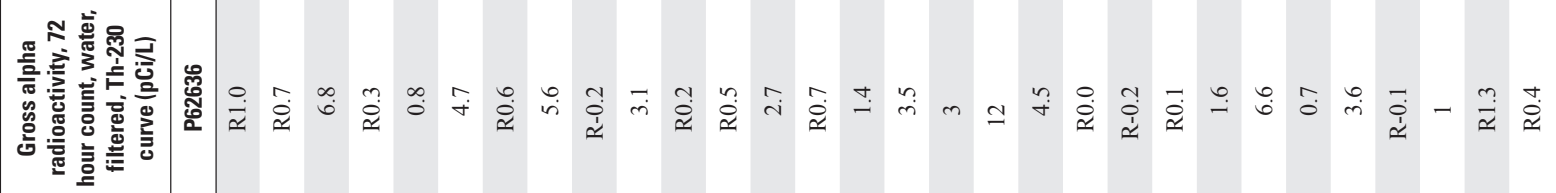

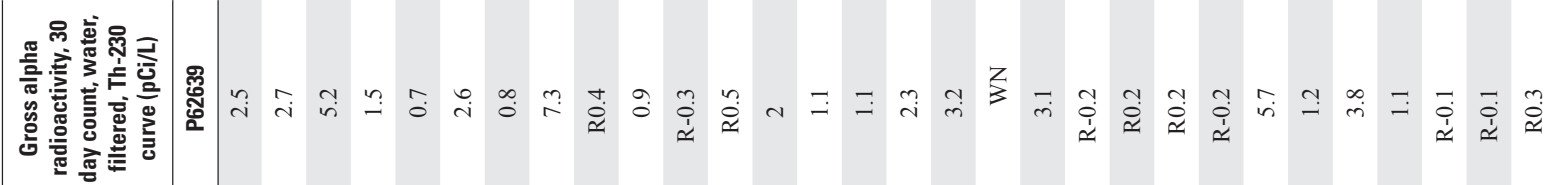

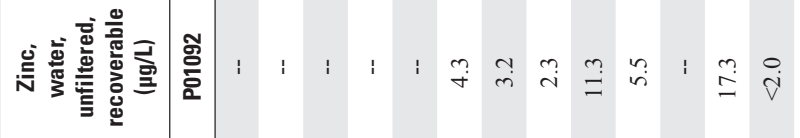

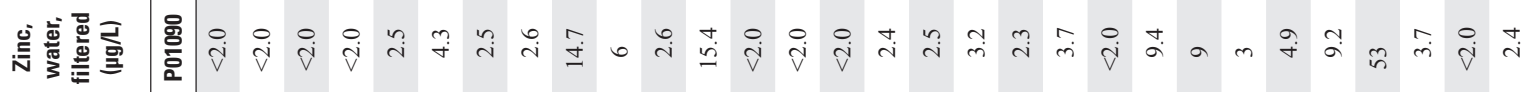

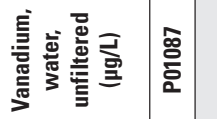

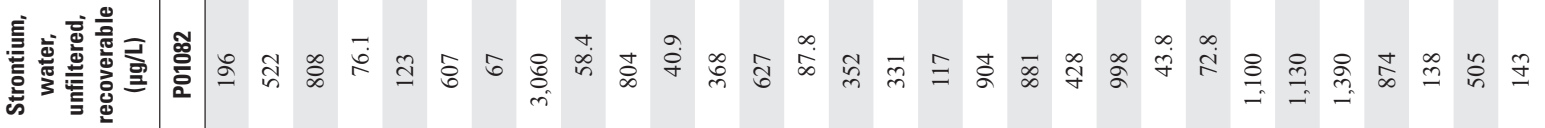

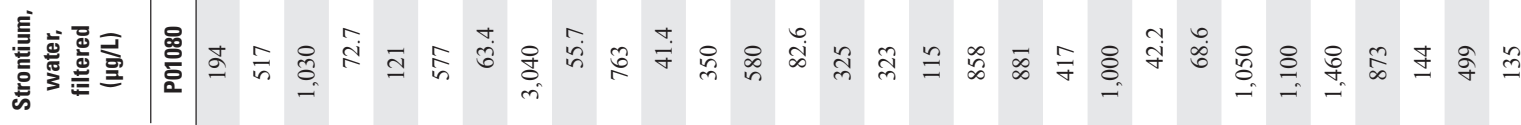

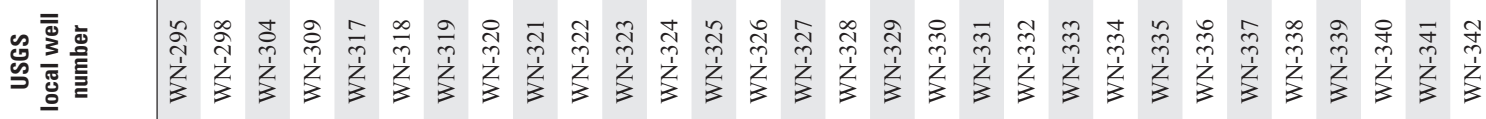




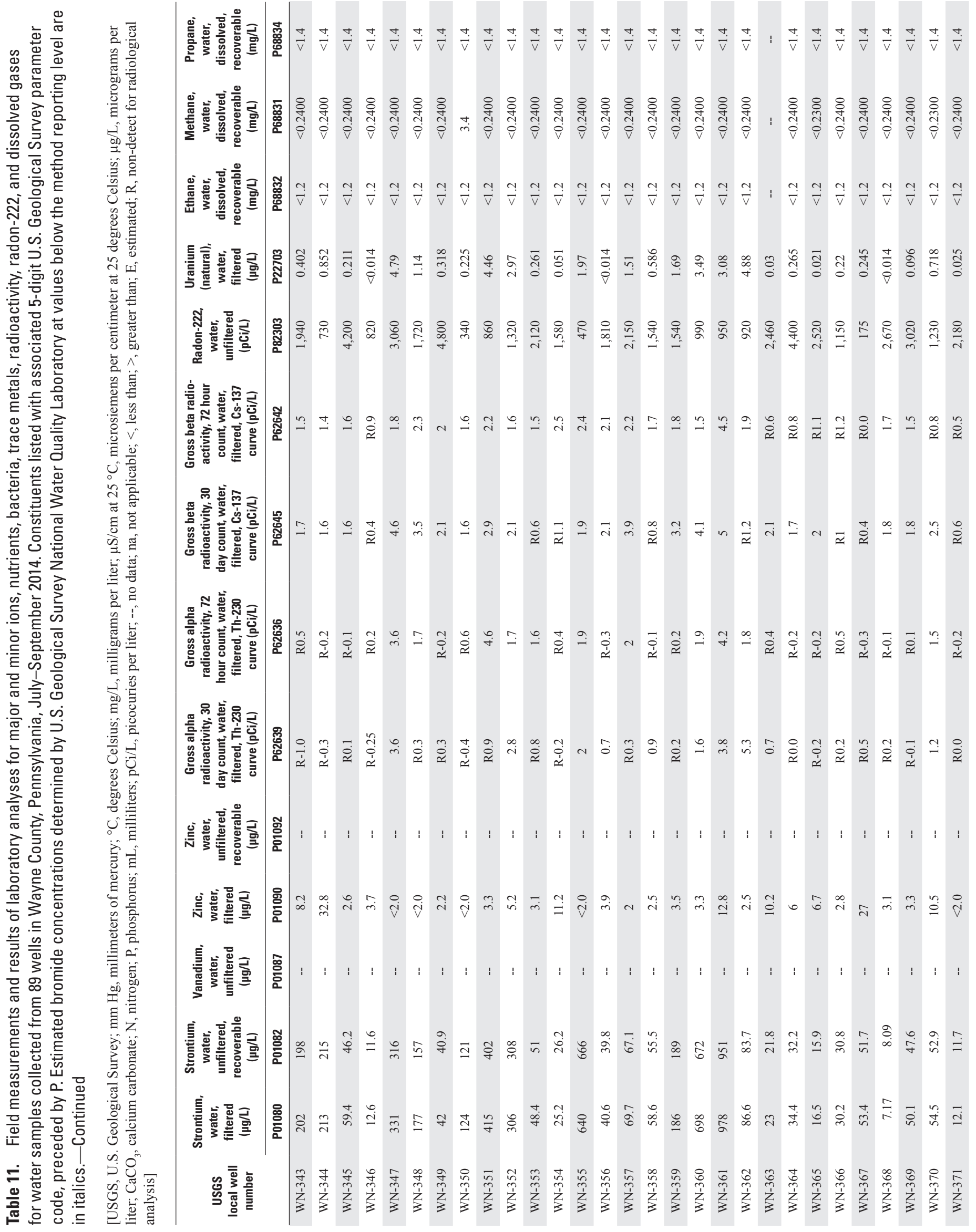




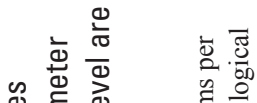

¿ ह 증

त

잉

응 원

에 ๘

응 음

듬을

층 엉

亡

응

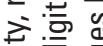

交 光

잉

든 $\frac{\pi}{0}$

को

점 क्

吃 寻

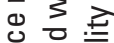

뉸 氙

은 車

过 产

을

我 든

可记

送

드를

으 틈

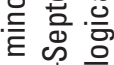

잉ㅇㅇ

於

을

츠

क्ष के 잉

放

元市

तั

공 ڤ

떤 으

흥 ๘

즈 त

오

es $\subseteq$ क

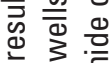

읃 이음

ส

녿 은 웡

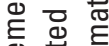

产皆

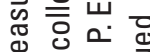

ㄴ

흥 응 훙

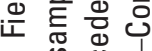

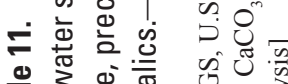

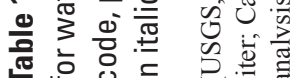

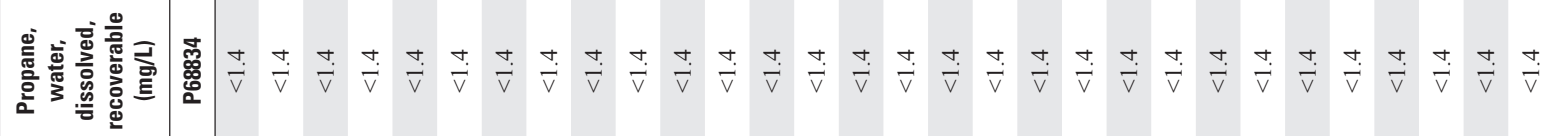

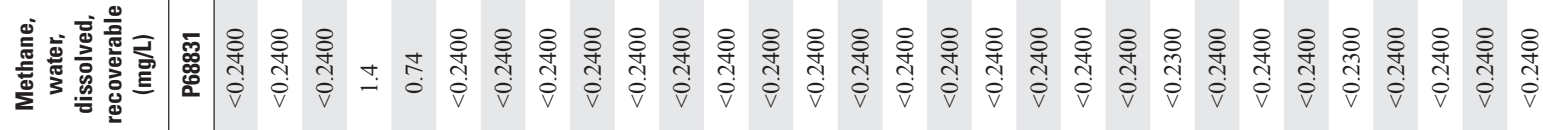

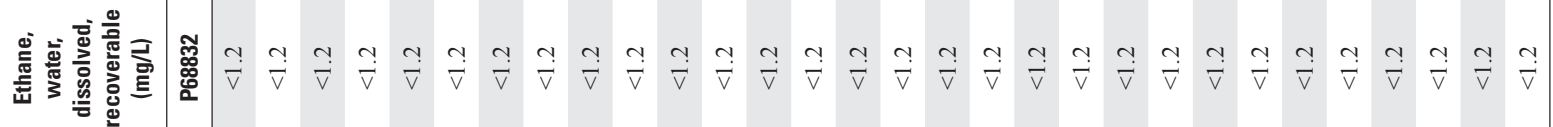

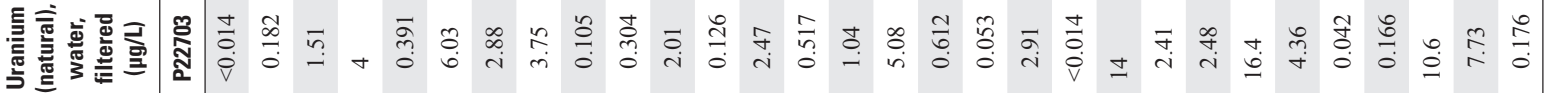

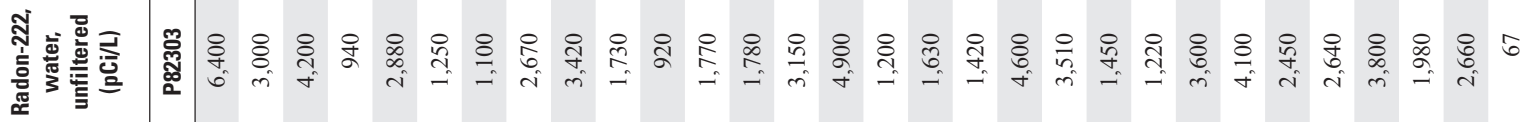

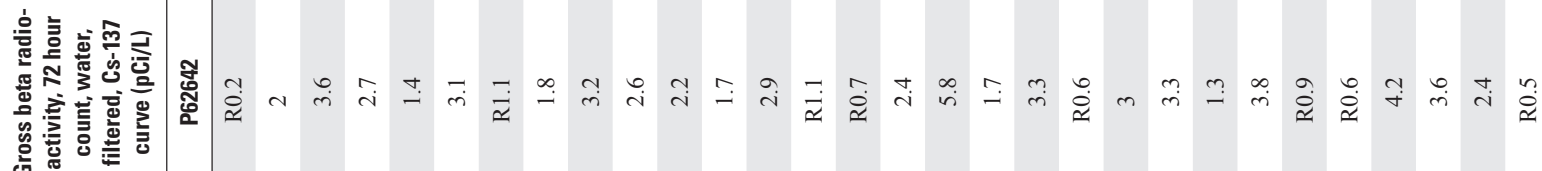

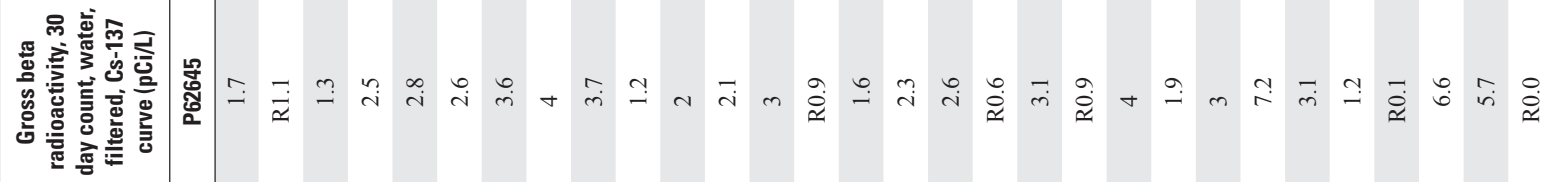

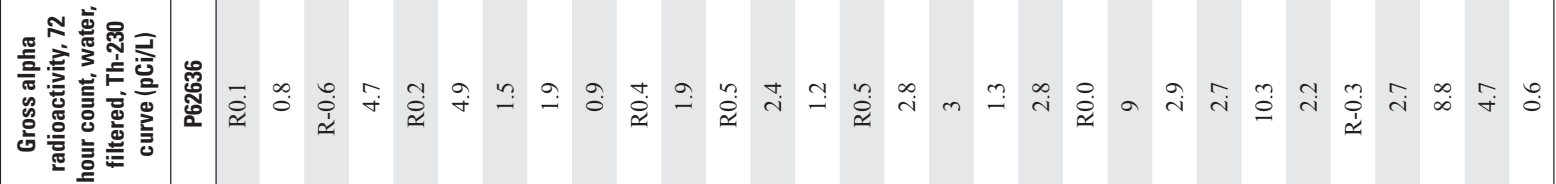

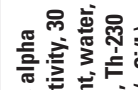

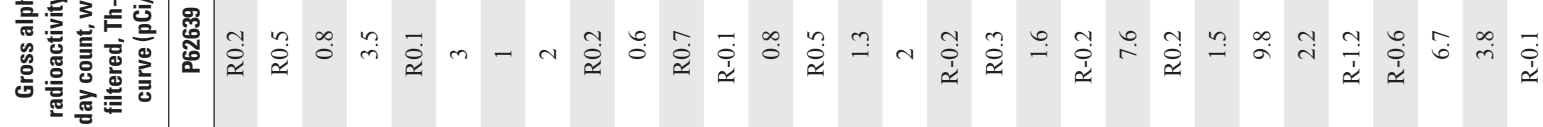

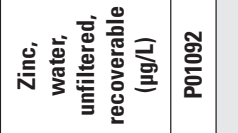

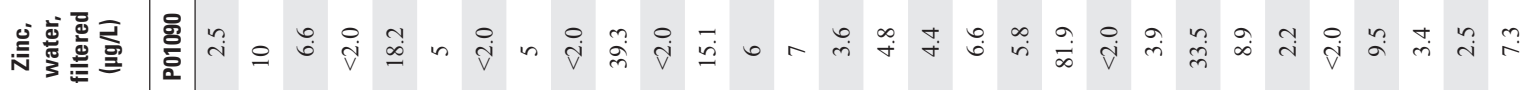

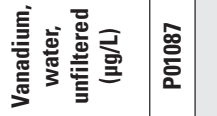

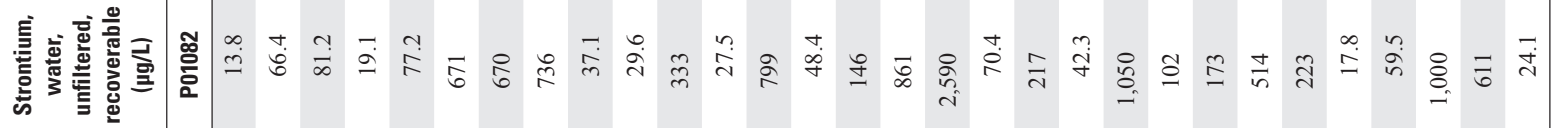

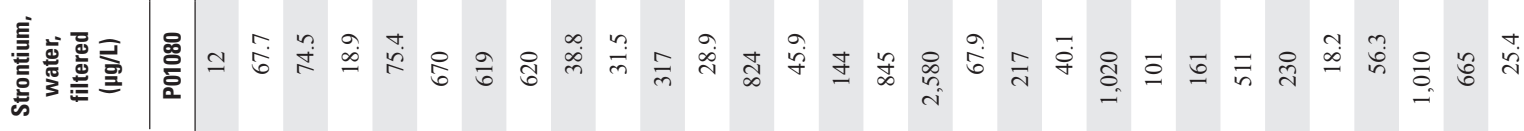

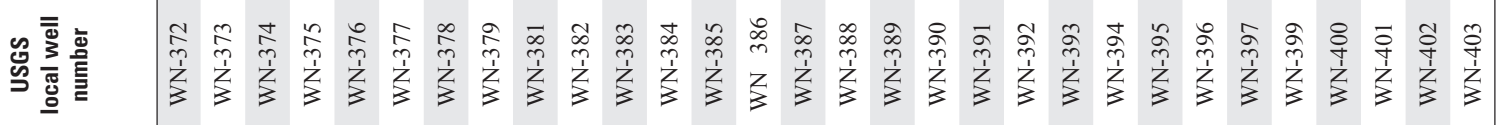




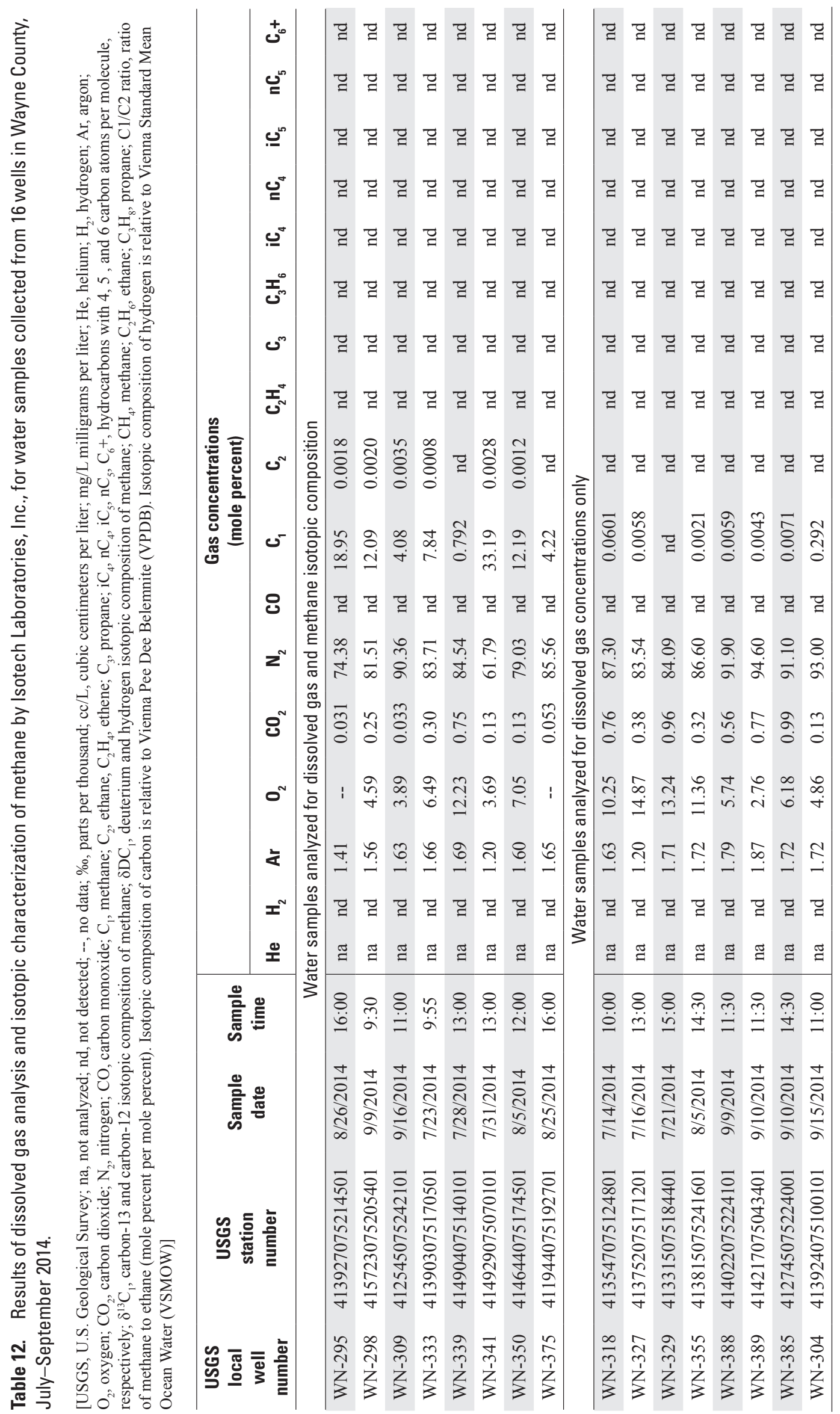




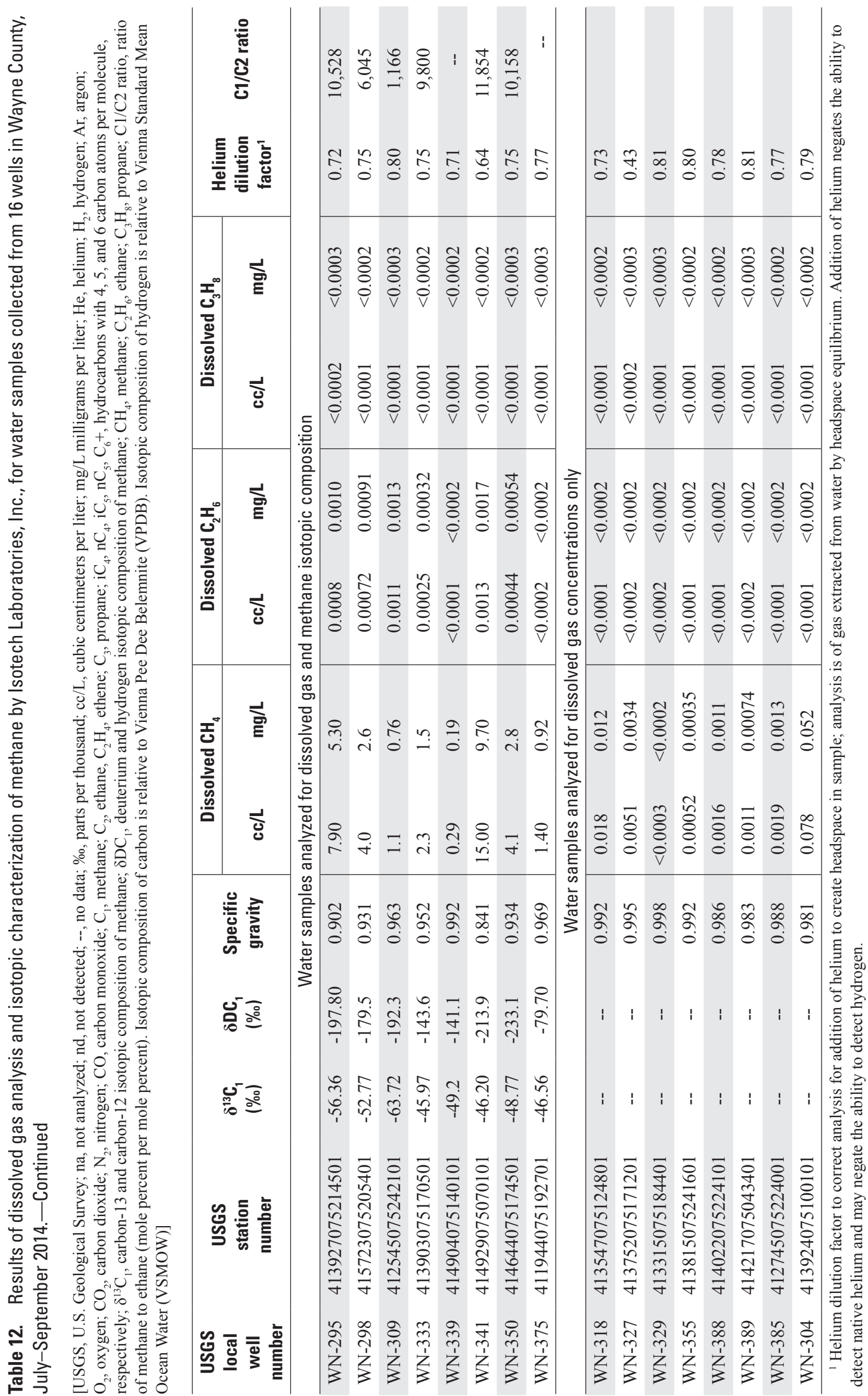





\section{Appendixes 1-4}


Table A1-1. Minimum, median, and maximum of well characteristics, chemical properties measured in the field, and concentrations of total dissolved solids, major ions, nutrients, and selected hydrocarbon gases determined in the laboratory for water samples collected from 34 wells in Wayne County, Pennsylvania, 2011 and 2013 (Data from Sloto, 2014).

$\left[\mu \mathrm{S} / \mathrm{cm}\right.$, microsiemens per centimeter at 25 degrees Celsius; $\mathrm{mg} / \mathrm{L}$ as $\mathrm{CaCO}_{3}$, milligrams per liter as calcium carbonate; $\mathrm{mg} / \mathrm{L}$, milligrams per liter; ${ }^{\circ} \mathrm{C}$, degrees Celsius; $\mathrm{SiO}_{2}$, silica; $\mathrm{mg} / \mathrm{L}$ as N, milligrams per liter as nitrogen; $\mathrm{mg} / \mathrm{L}$ as $\mathrm{P}$, milligrams per liter as phosphorus; --, no data or not applicable; $\mathrm{MCL}$, maximum contaminant level; HA, Health Advisory; SMCL, secondary maximum contaminant level; <, less than]

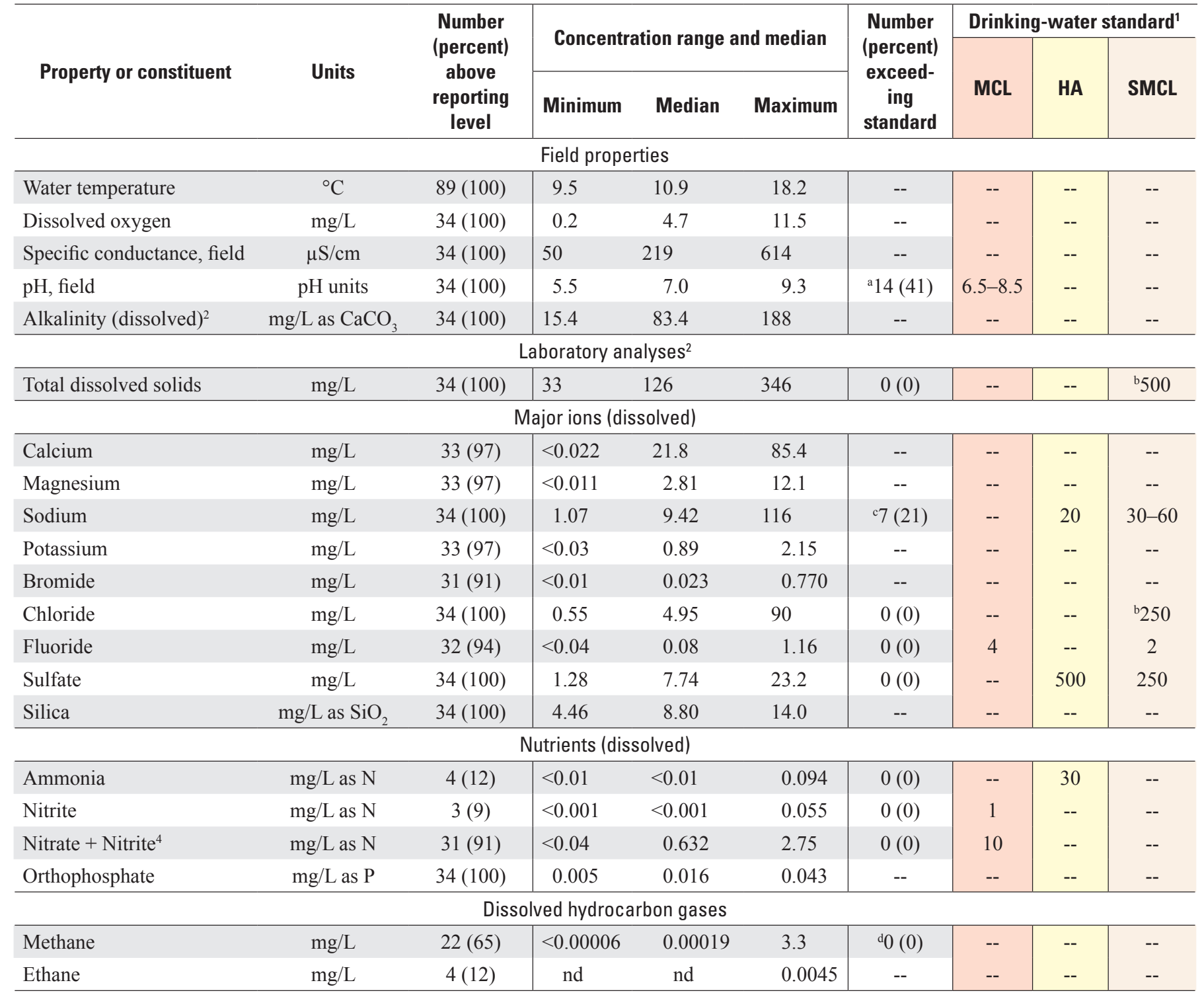

${ }^{1}$ U.S. Environmental Protection Agency (2012).

${ }^{2}$ Alkalinity was determined in the field for 32 samples and in the laboratory for 2 samples.

${ }^{3}$ Laboratory analyses done by U.S. Geological Survey National Water Quality Laboratory (NWQL).

${ }^{4}$ Because nitrite concentrations are low, nitrate is nearly equivalent to nitrate plus nitrite.

${ }^{\mathrm{a}} \mathrm{pH}$ was less than 6.5 in 11 samples (32 percent) and greater than 8.5 in 3 samples ( 9 percent).

${ }^{\mathrm{b}}$ Same standard established by Pennsylvania Department of Environmental Protection (2010) for flow-back discharge to streams.

${ }^{c}$ Seven samples exceed HA of $20 \mathrm{mg} / \mathrm{L}$ and 3 samples exceed upper SMCL limit of $60 \mathrm{mg} / \mathrm{L}$ for sodium.

d No drinking-water standard; in Pennsylvania, action level for methane in well water is $7 \mathrm{mg} / \mathrm{L}$ to minimize hazards related to explosion (Commonwealth of Pennsylvania, 2014). 
Table A1-2. Minimum, median, and maximum dissolved trace constituent concentrations and total gross alpha- and gross betaparticle, and radon-222 radioctivities determined in the laboratory for water samples collected from 34 wells in Wayne County, Pennsylvania, 2011 and 2013 (Data from Sloto, 2014).

$[\mu \mathrm{g} / \mathrm{L}$, micrograms per liter; <, less than; --, no data or not applicable; $\mathrm{pCi} / \mathrm{L}$, picocuries per liter; mrem/yr, millirem per year; $\mathrm{MCL}$, maximum contaminant level; HA, Health Advisory; SMCL, secondary maximum level]

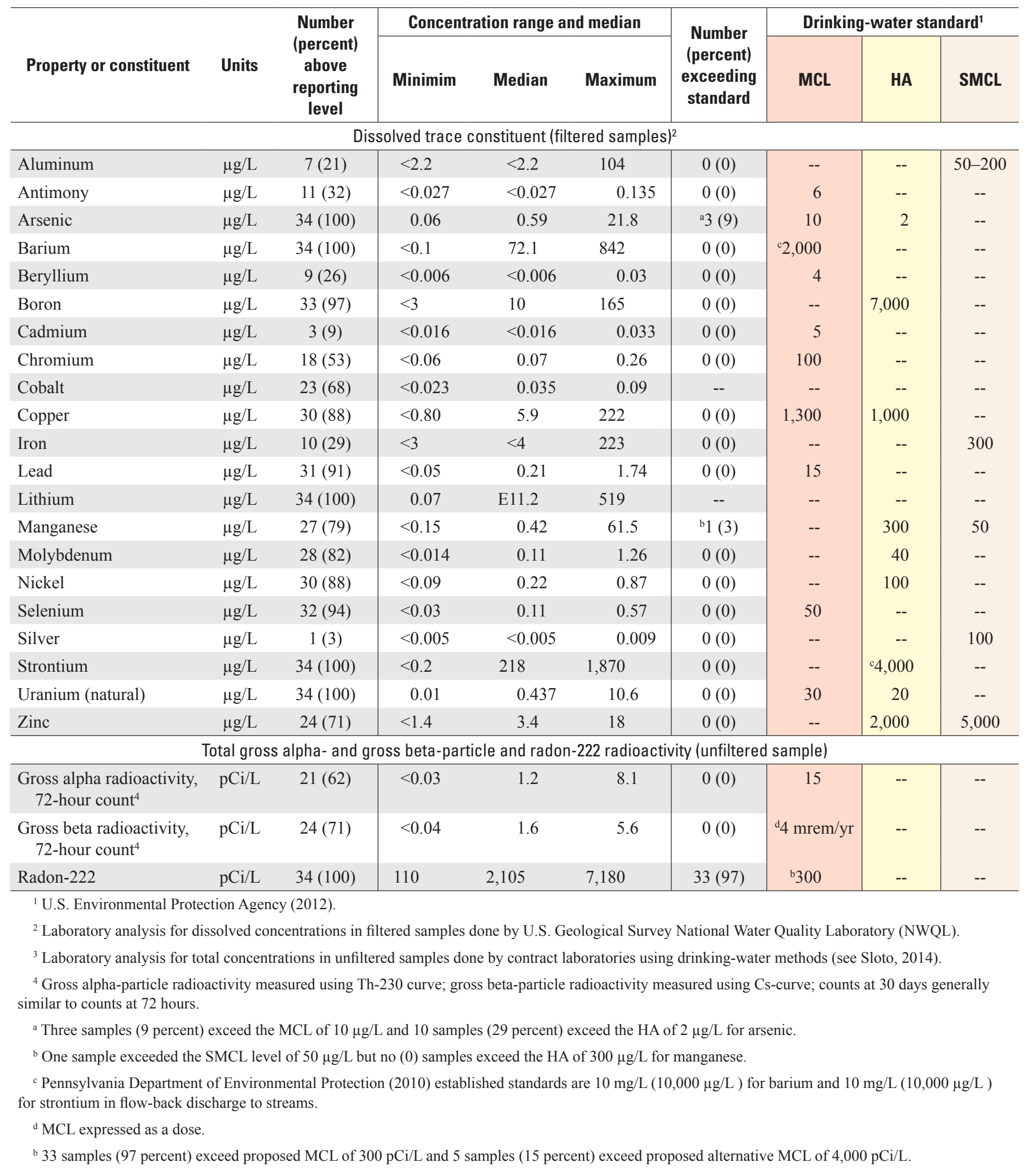


Table A2-1. Methods used for determination of dissolved major ions, trace constituents, nutrients, and alkalinity by the U.S. Geological Survey National Water Quality Laboratory.

[USGS NWQL, U.S. Geological Survey National Water Quality Laboratory; $\mu \mathrm{g} / \mathrm{L}$, micrograms per liter; mg/L, milligrams per liter, $\mu \mathrm{S} / \mathrm{cm}$, microsiemens per centimeter at 25 degrees Celsius; ICP-MS, inductively coupled plasma mass spectrometry; TDS, total dissolved solids]




Table A2-2. Methods and reporting levels used for determination of gross alpha and beta radioactivity, and radon-222 by the U.S. Geological Survey National Water Quality Laboratory.

[USGS NWQL, U.S. Geological Survey National Water Quality Laboratory; pCi/L, picocuries perf liter]

\begin{tabular}{|c|c|c|c|}
\hline Analyte & Parameter code & Reporting level & Unit \\
\hline \multicolumn{4}{|c|}{ USGS NWOL Schedule 1792-Description: Gross alpha/beta, water, filtered, 72-hour/30-day count by method EPA 900.0} \\
\hline Gross-alpha radioactivity & 62639 & 3 & $\mathrm{pCi} / \mathrm{L}$ \\
\hline Gross-beta radioactivity & 62642 & 4 & $\mathrm{pCi} / \mathrm{L}$ \\
\hline Gross-beta radioactivity & 62645 & 4 & $\mathrm{pCi} / \mathrm{L}$ \\
\hline Radon-222 & 82303 & 20 & $\mathrm{pCi} / \mathrm{L}$ \\
\hline
\end{tabular}


Table A2-3. Methods used for determination of major ions, trace constituents, and constituents determined by contract laboratories for Wayne County, Pennsylvania, groundwater samples collected in 2014.

[USGS, U.S.Geological Survey; EPA, U.S. Environmental Protection Agency; PADEP, Pennsylvania Department of Environmental Protection; PQL, practical quantification limit; $\mathrm{MDL}$, method detection level; $\mathrm{mg} / \mathrm{L}$, milligrams per liter; $\mathrm{CaCO}_{3}$, calcium carbonate; VOCs, volatile organic compounds; ICP, inductively coupled plasma; na, not analyzed]

\begin{tabular}{|c|c|c|c|c|c|}
\hline Analyte & $\begin{array}{c}\text { USGS } \\
\text { parameter } \\
\text { code }\end{array}$ & POL & MDL & Unit & Method \\
\hline \multicolumn{6}{|c|}{ Environmental Services Laboratories, Inc.: Dissolved gases by method PADEP 3686} \\
\hline Ethane & P68832 & 1.24 & 0.95 & $\mathrm{mg} / \mathrm{L}$ & PADEP 3686 \\
\hline Methane & P68831 & 0.24 & 0.11 & $\mathrm{mg} / \mathrm{L}$ & PADEP 3686 \\
\hline Propane & P68834 & 1.42 & 0.59 & $\mathrm{mg} / \mathrm{L}$ & PADEP 3686 \\
\hline \multicolumn{6}{|c|}{ Fairway Laboratories, Inc.: Gylcols by EPA method 8015 (modified) or SW846 8015D } \\
\hline Ethylene glycol & P52529 & 5.00 & 1.25 & $\mathrm{mg} / \mathrm{L}$ & EPA8015 (mod) \\
\hline Proplylene glycol & P52530 & 5.00 & 0.643 & $\mathrm{mg} / \mathrm{L}$ & EPA 8015 (mod) \\
\hline \multicolumn{6}{|c|}{ Fairway Laboratories, Inc.: Anions by EPA method 300.0/2.1 } \\
\hline Chloride & P99220 & 10.00 & 2.76 & $\mathrm{mg} / \mathrm{L}$ & EPA $300.0 / 2.1$ \\
\hline \multicolumn{6}{|c|}{ Mountain Research, LLC: Various analytes by various methods } \\
\hline Oil and grease & P00552 & 5.00 & 1.07 & $\mathrm{mg} / \mathrm{L}$ & EPA 1664 \\
\hline $\begin{array}{l}\text { Total dissolved solids } \\
\text { (residue, filterable) }\end{array}$ & P70300 & 10.00 & na & $\mathrm{mg} / \mathrm{L}$ & SM $2540 \mathrm{C}$ \\
\hline Total solids & P00500 & 10.00 & na & $\mathrm{mg} / \mathrm{L}$ & SM 2540B \\
\hline Total suspended solids & P70293 & 10.00 & na & $\mathrm{mg} / \mathrm{L}$ & SM 2540D \\
\hline Potassium & P00937 & 0.50 & 0.0094 & $\mathrm{mg} / \mathrm{L}$ & SM 3111 B, metals by Flame AAS \\
\hline Sodium & P00929 & 20.00 & 4.14 & $\mathrm{mg} / \mathrm{L}$ & SM 3111 B, metals by Flame AAS \\
\hline Hardness & P00907 & 3.31 & 0.101 & $\mathrm{mg} / \mathrm{L}$ as $\mathrm{CaCO}_{3}$ & SM 2340 B, metals by ICP \\
\hline Manganese & P01055 & 0.0005 & & $\mathrm{mg} / \mathrm{L}$ & EPA 200.8 \\
\hline \multicolumn{6}{|c|}{ Seewald Laboratories: VOCs and alcohols } \\
\hline $\begin{array}{l}\text { VOCs - see table } 6 \text { for listing of } \\
\text { analytes and reporting levels }\end{array}$ & & & & & EPA 524.2 \\
\hline $\begin{array}{l}\text { Alcohols - see table } 6 \text { for listing } \\
\text { of analytes and reporting levels }\end{array}$ & & & & & EPA 8015 C (mod) \\
\hline
\end{tabular}



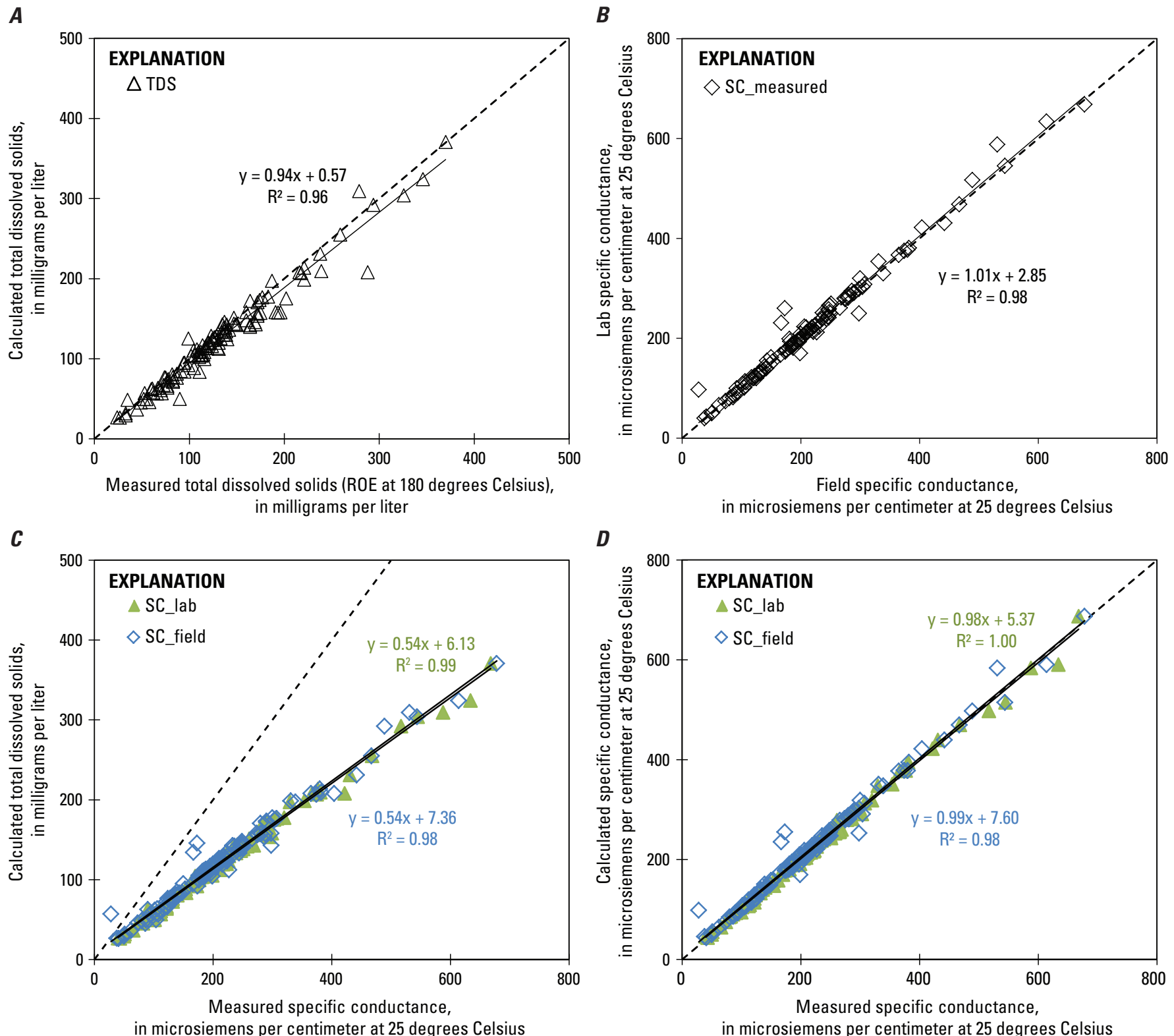

Figure 3-1. Total dissolved solids and specific conductance for 121 groundwater samples collected from 117 wells in Wayne County, Pennsylvania, 2013-14. A, Relation of measured total dissolved solids [as residue on evaporation (ROE) at 180 degrees Celsius] to calculated total dissolved solids, $B$, relation of field measued specific conductance to laboratory measured specific conductance, $C$, relation of field measured specific conductance to calculated concentration of total dissolved solids, and $D$, relation of field measured specific conductance to specific conductance calculated on the basis of ionic conductivities. 


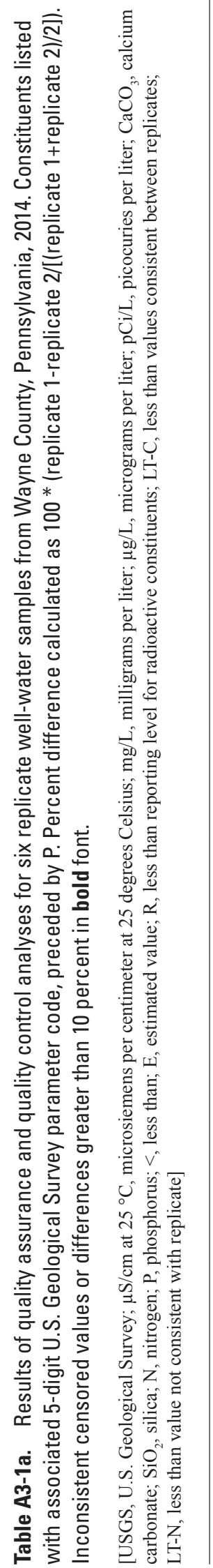

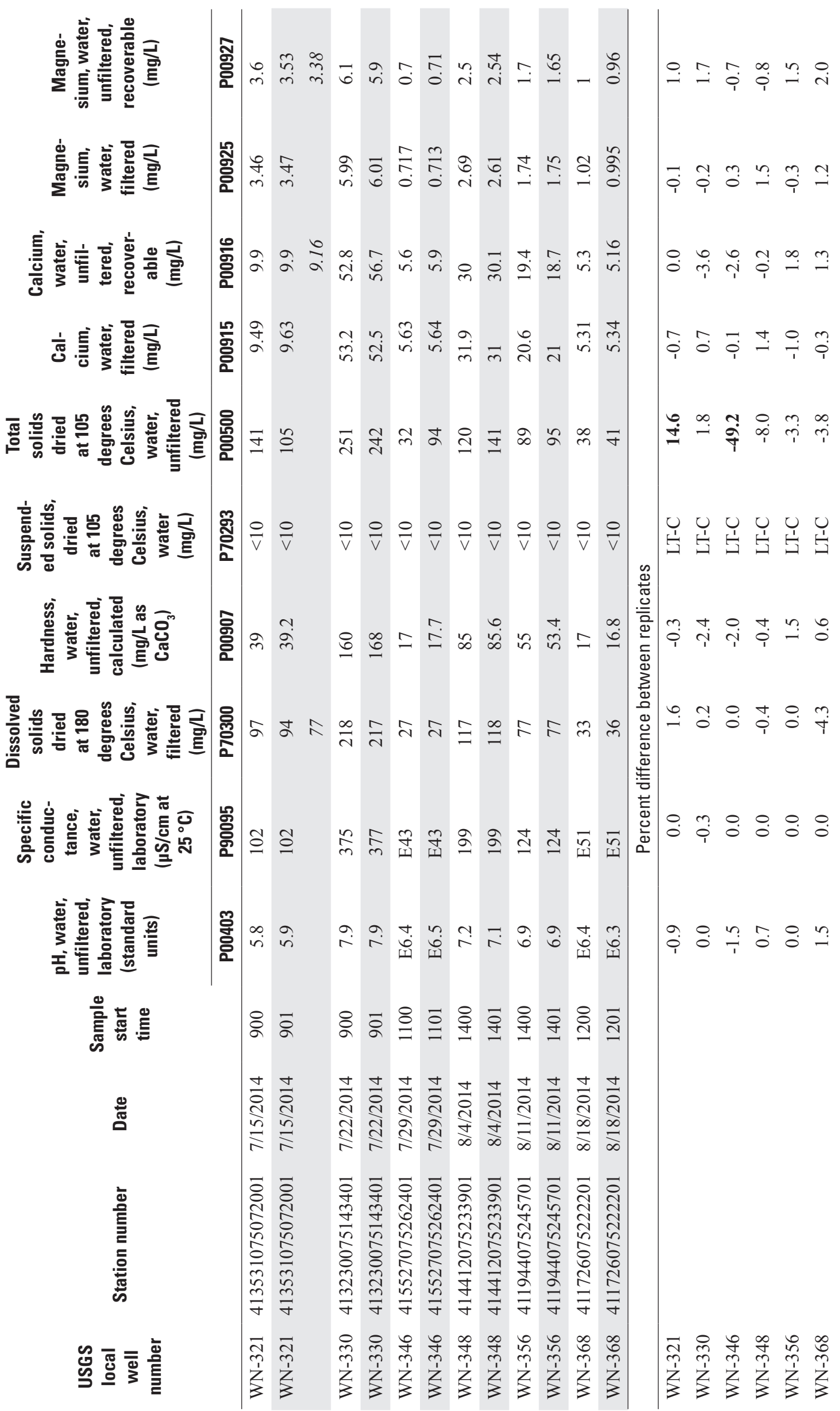




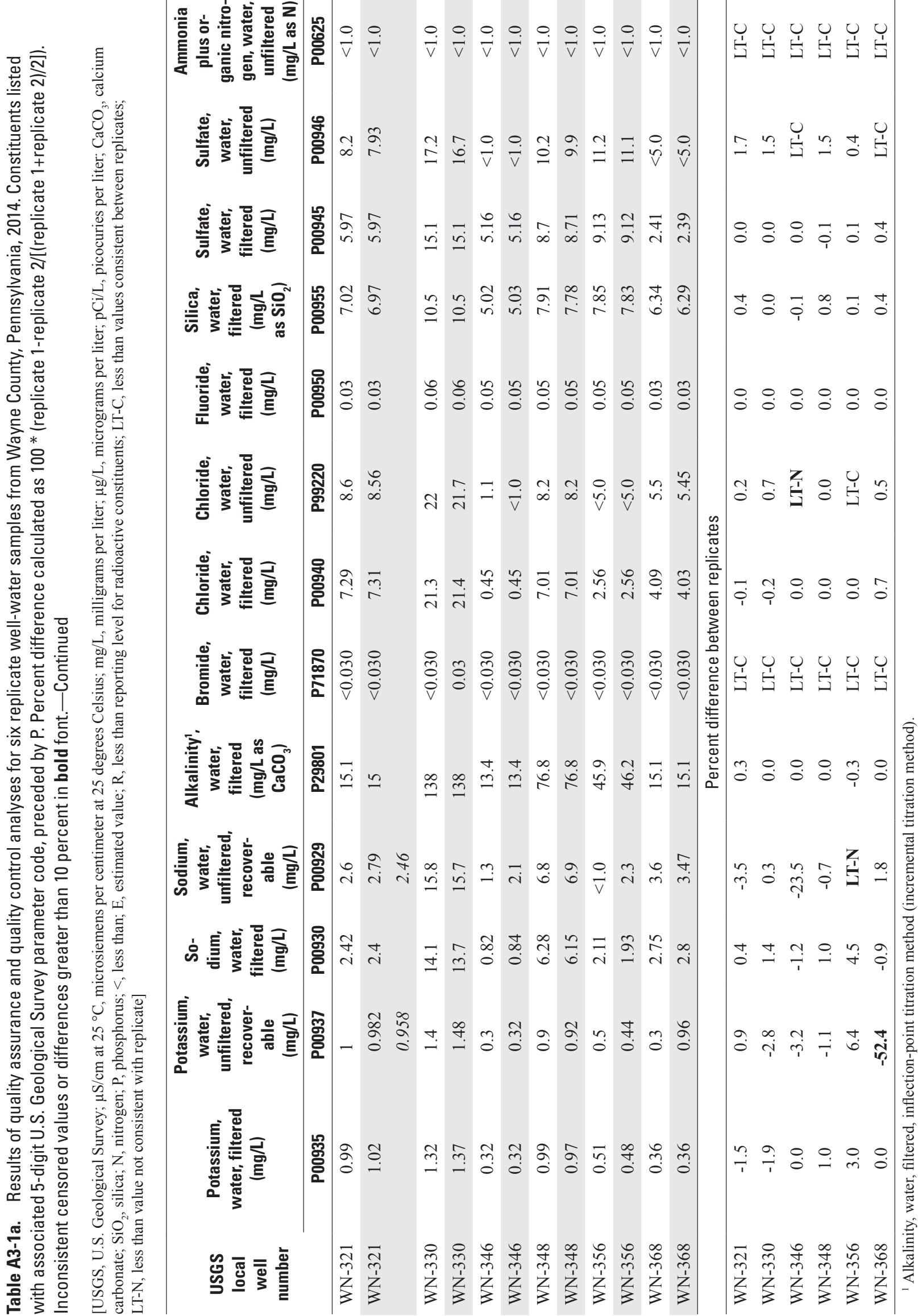




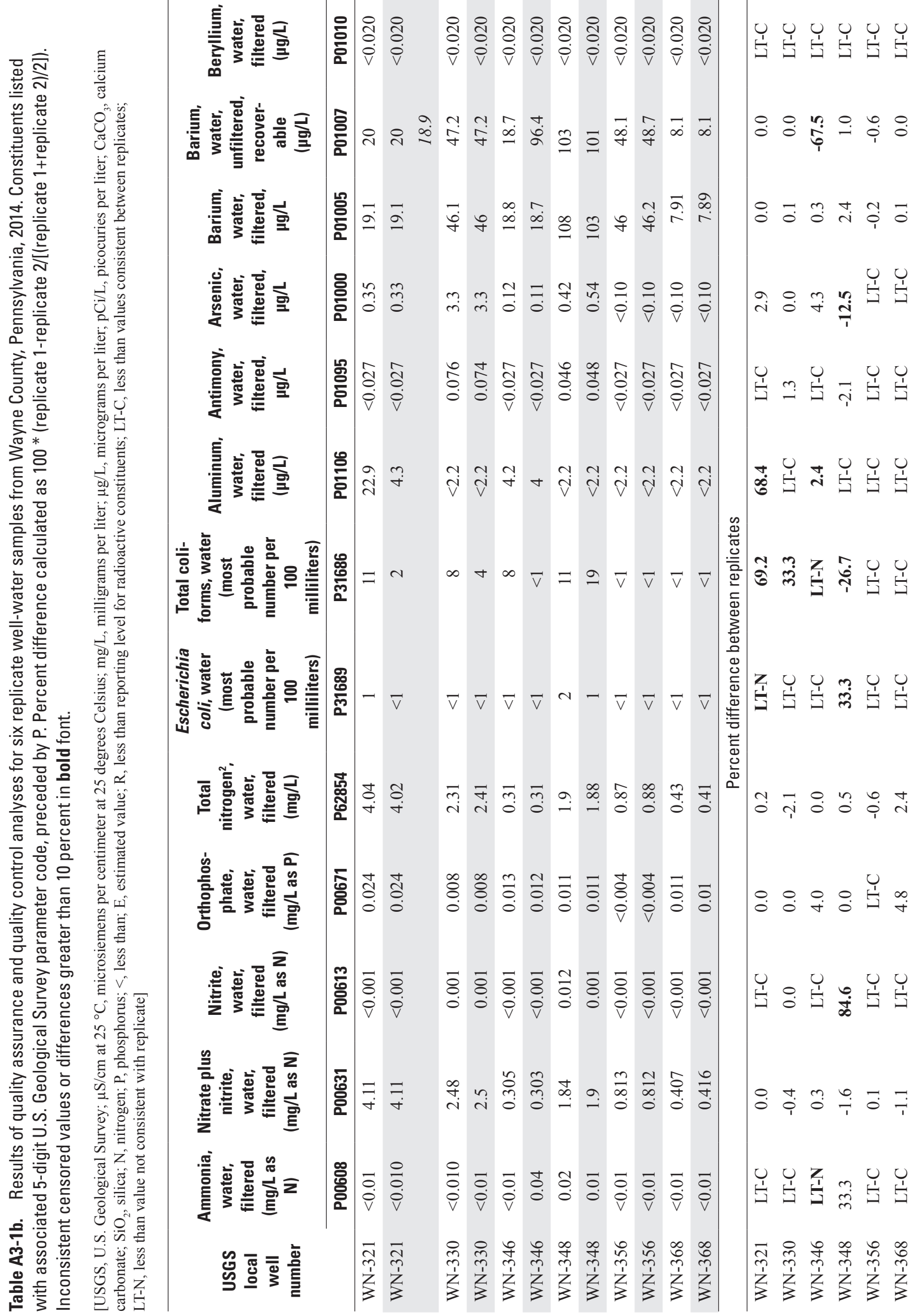




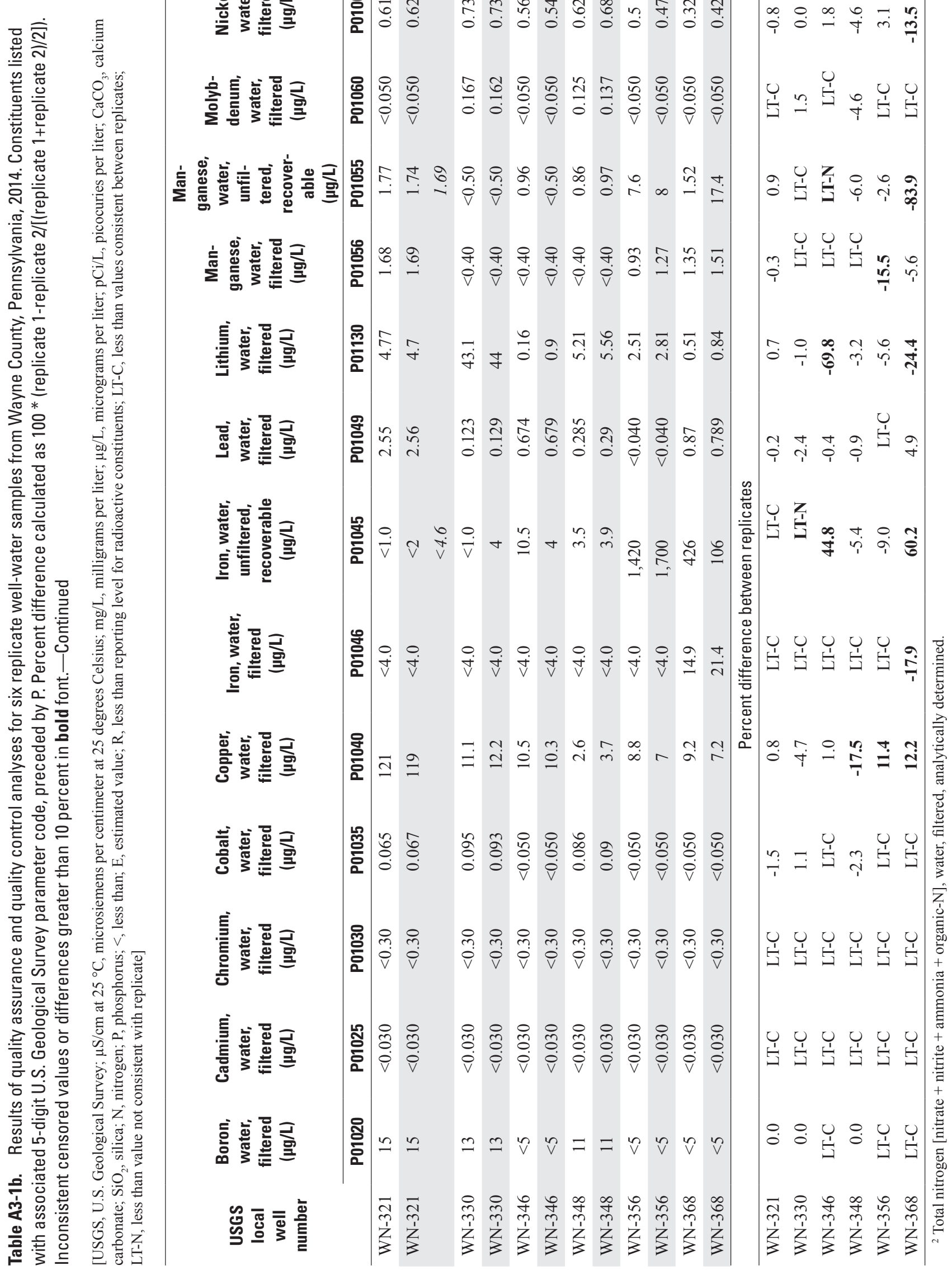




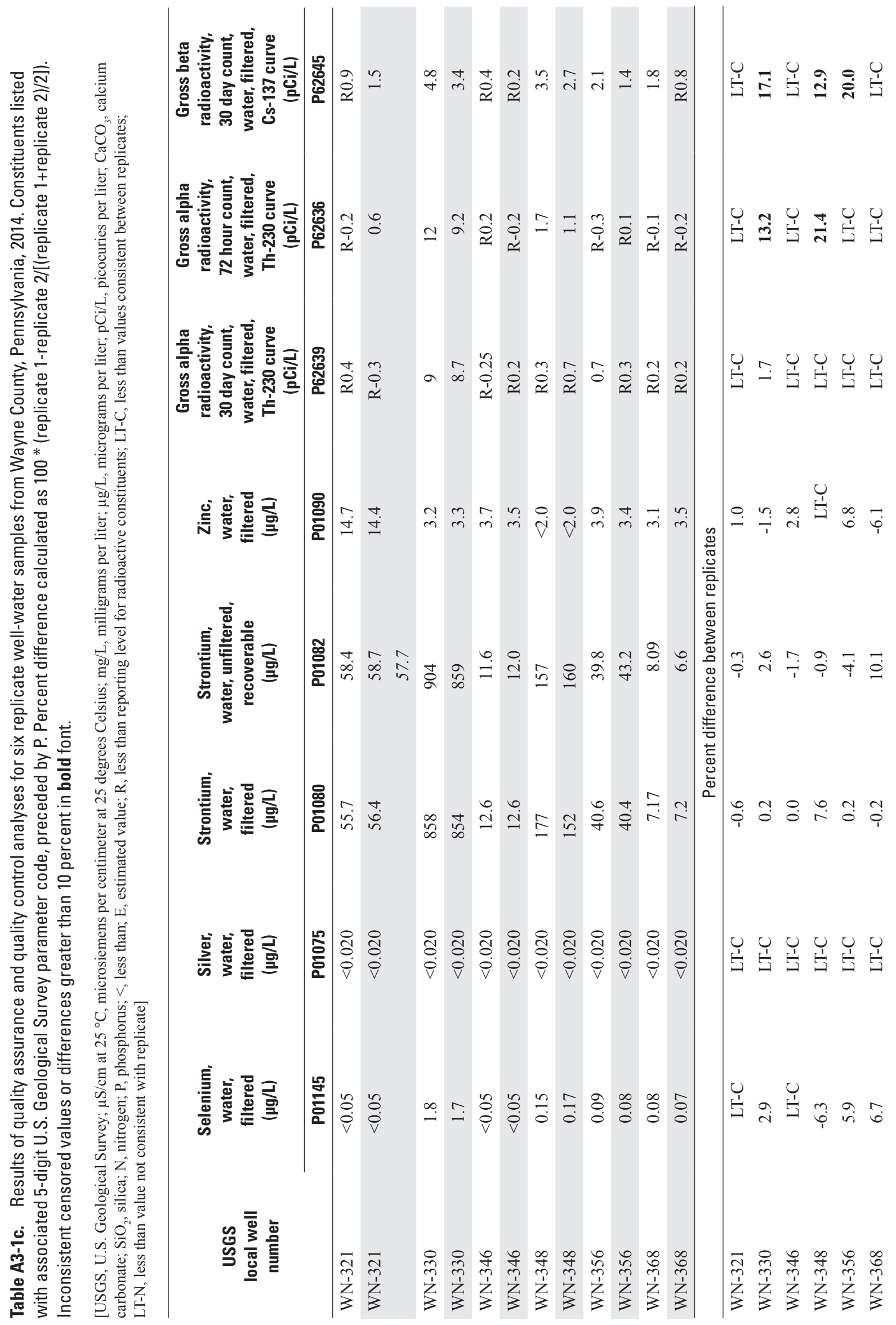




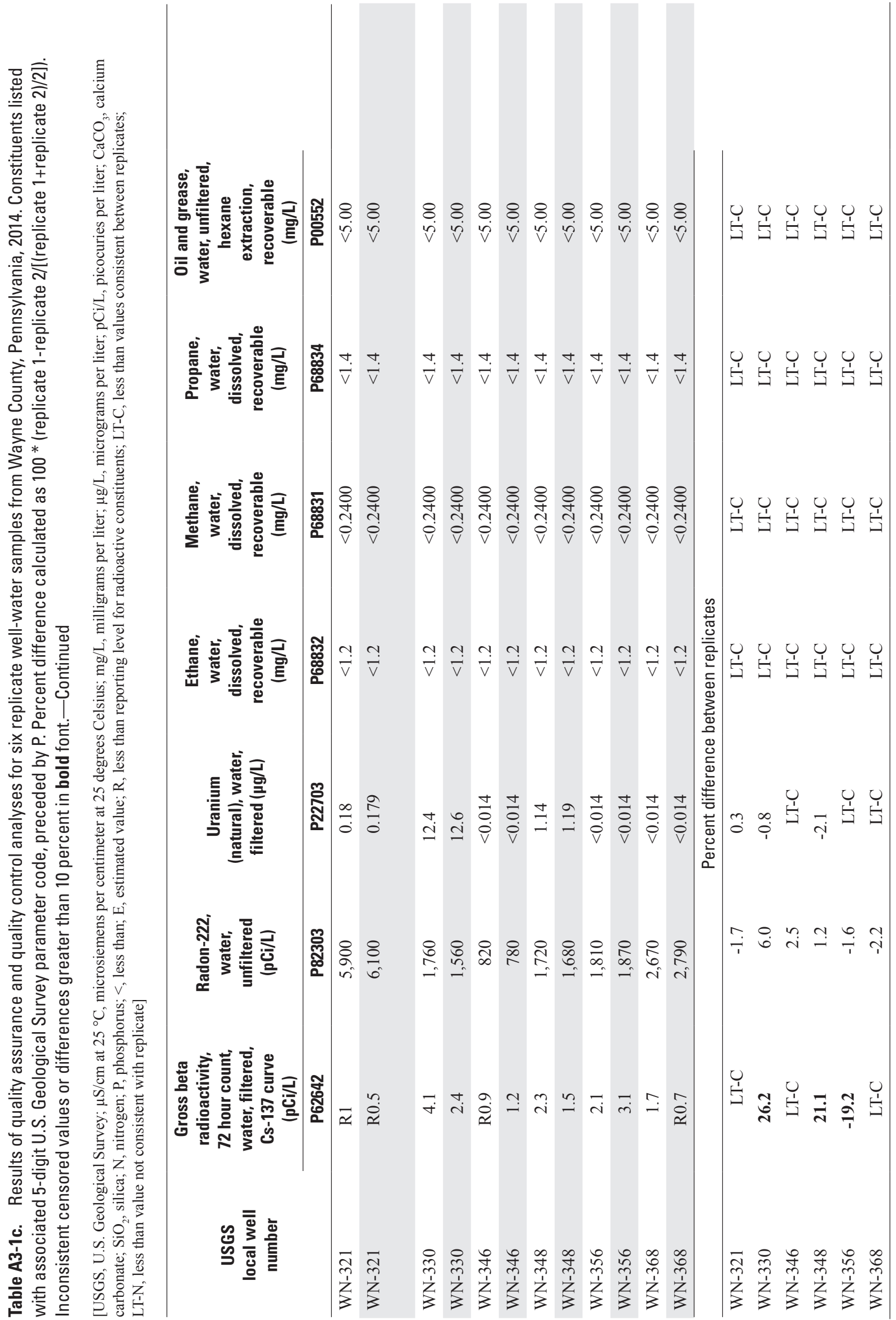


$\boldsymbol{A}$

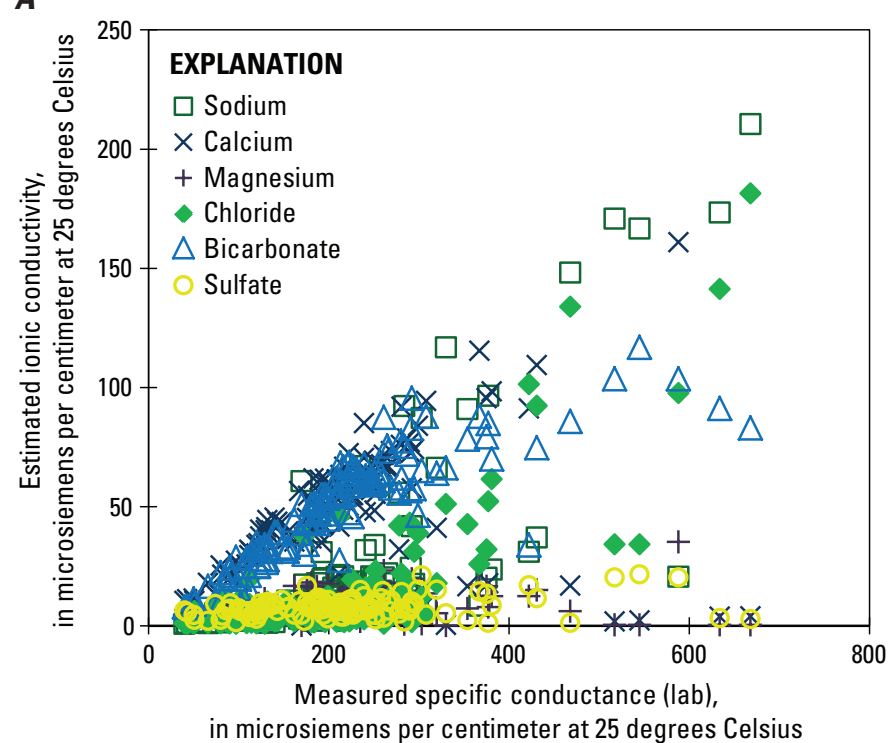

in microsiemens per centimeter at 25 degrees Celsius

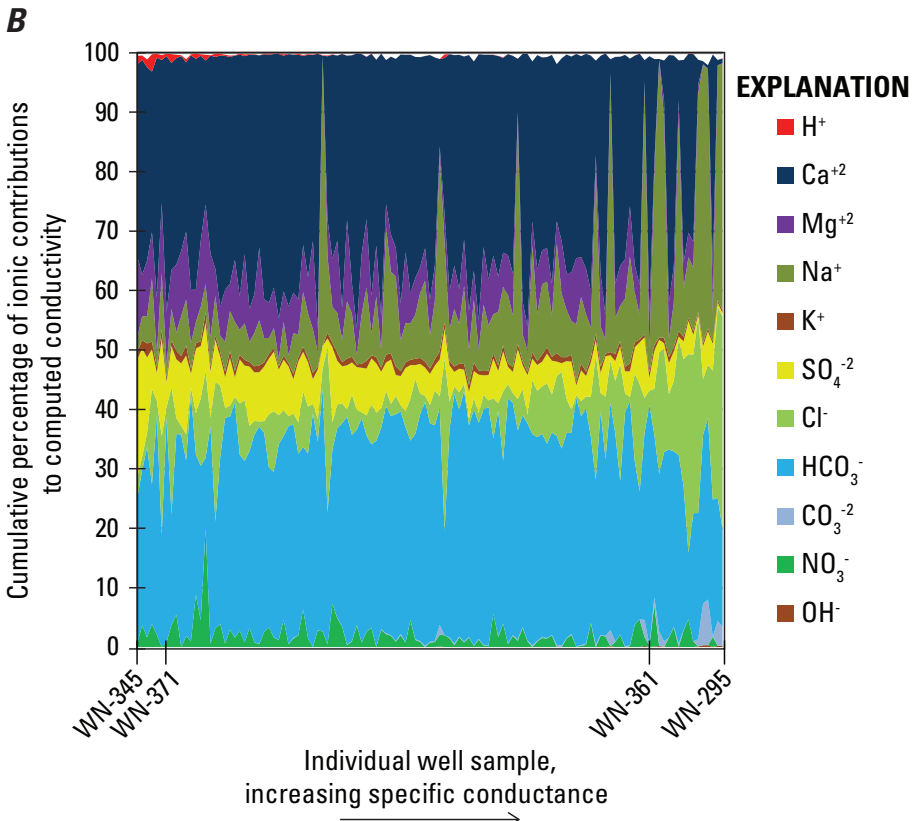

B increasing specific conductance

Figure 3-2. $\quad A$, Relation of laboratory measured specific conductance to estimated ionic conductivity, and $B$, cumulative percentage of ionic contributions to specific conductance/conductivity for 121 groundwater samples collected from 117 wells in Wayne County, Pennsylvania, 2013 and 2014, in order of increasing specific conductance. Four of 117 wells are identified by U.S. Geological Survey local well numbers in $B$. 


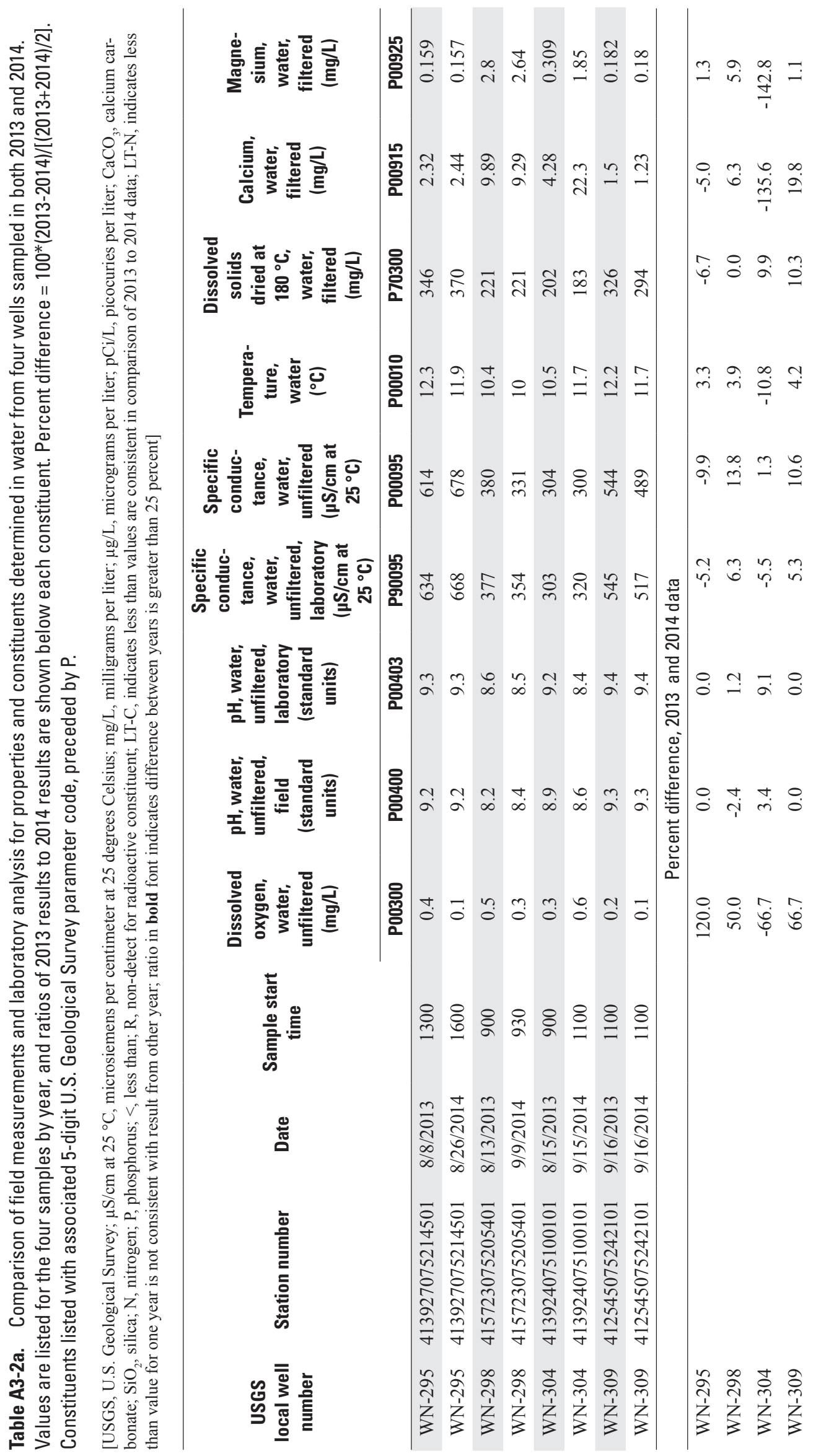




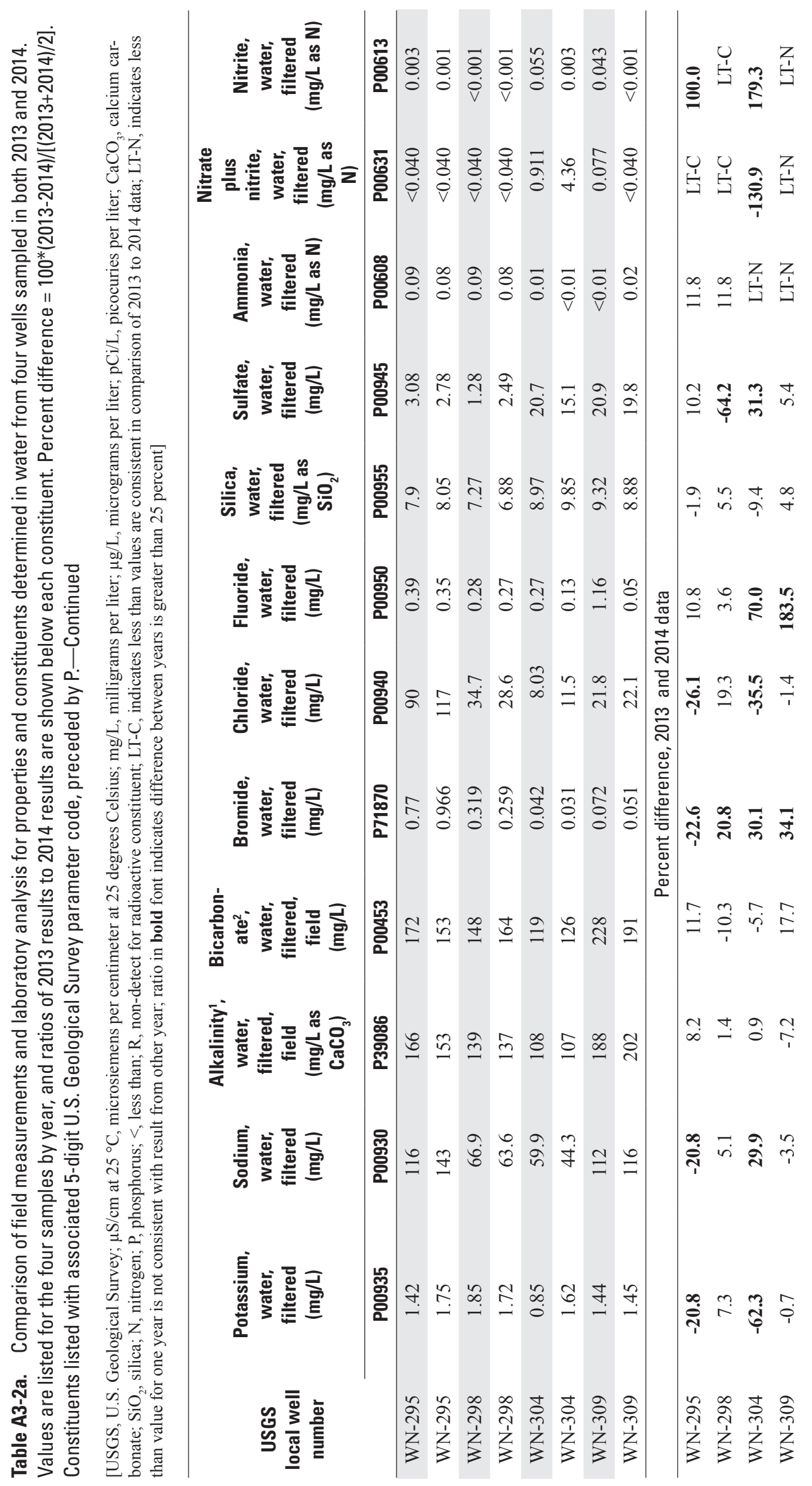




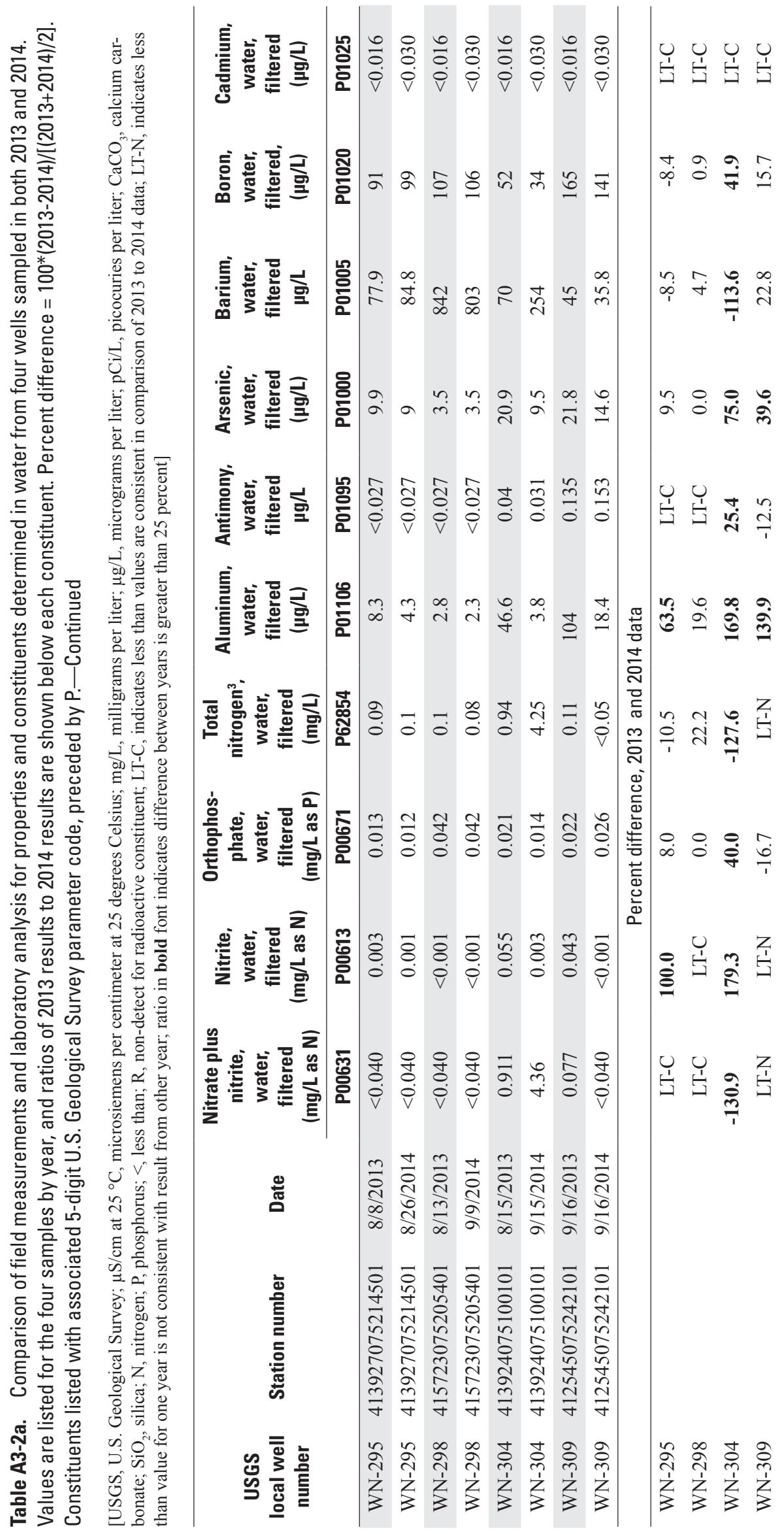




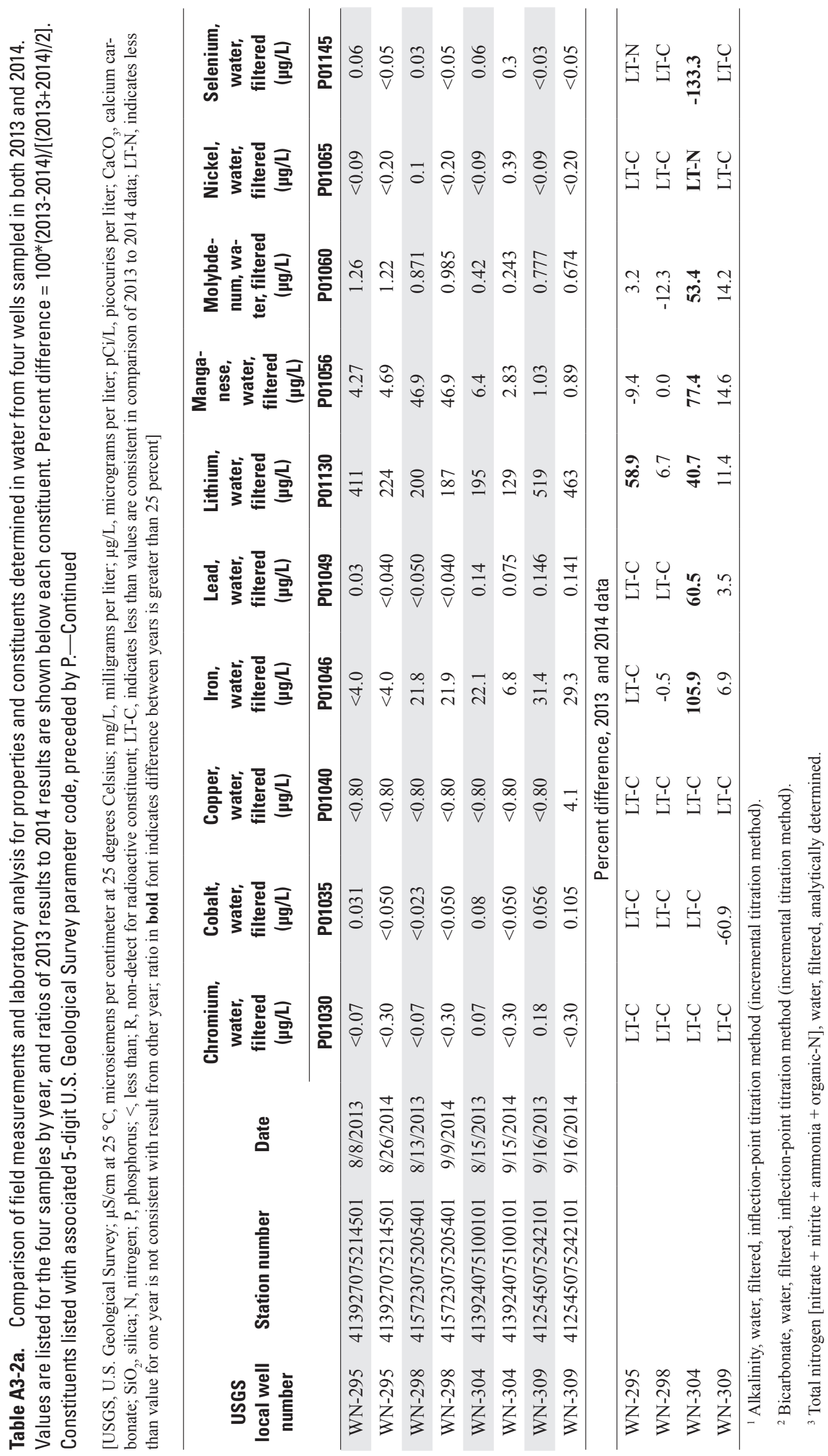




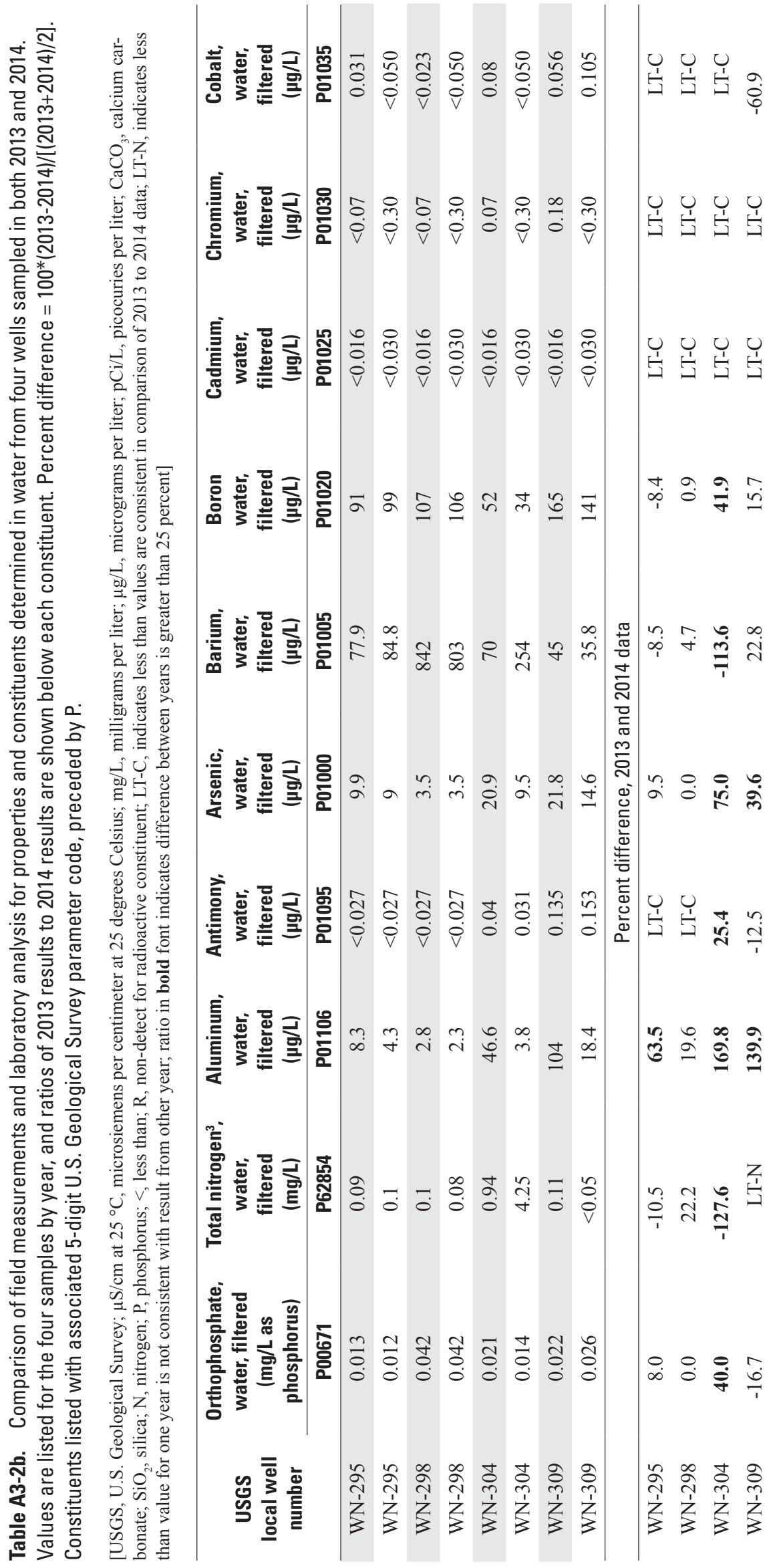




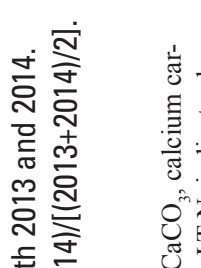

苂察

동

胥 ᄋ

II

उ热

言变

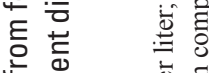

ऐ

离

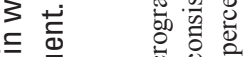

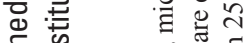

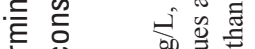

进

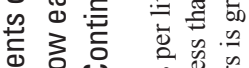

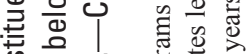

言产

동 $\frac{5}{4}$

車

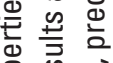

응 ब원

高辛

훟ㅎํ

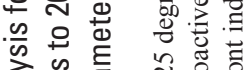

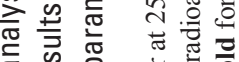

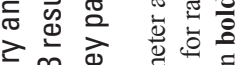

휸 誉

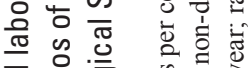

둖 휸 응

先它

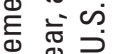

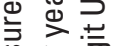

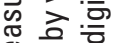

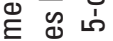

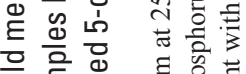

焉

드원

类要焉

릉홍

نे

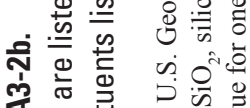

觜

iी

邻苛总

O

ठ․

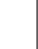

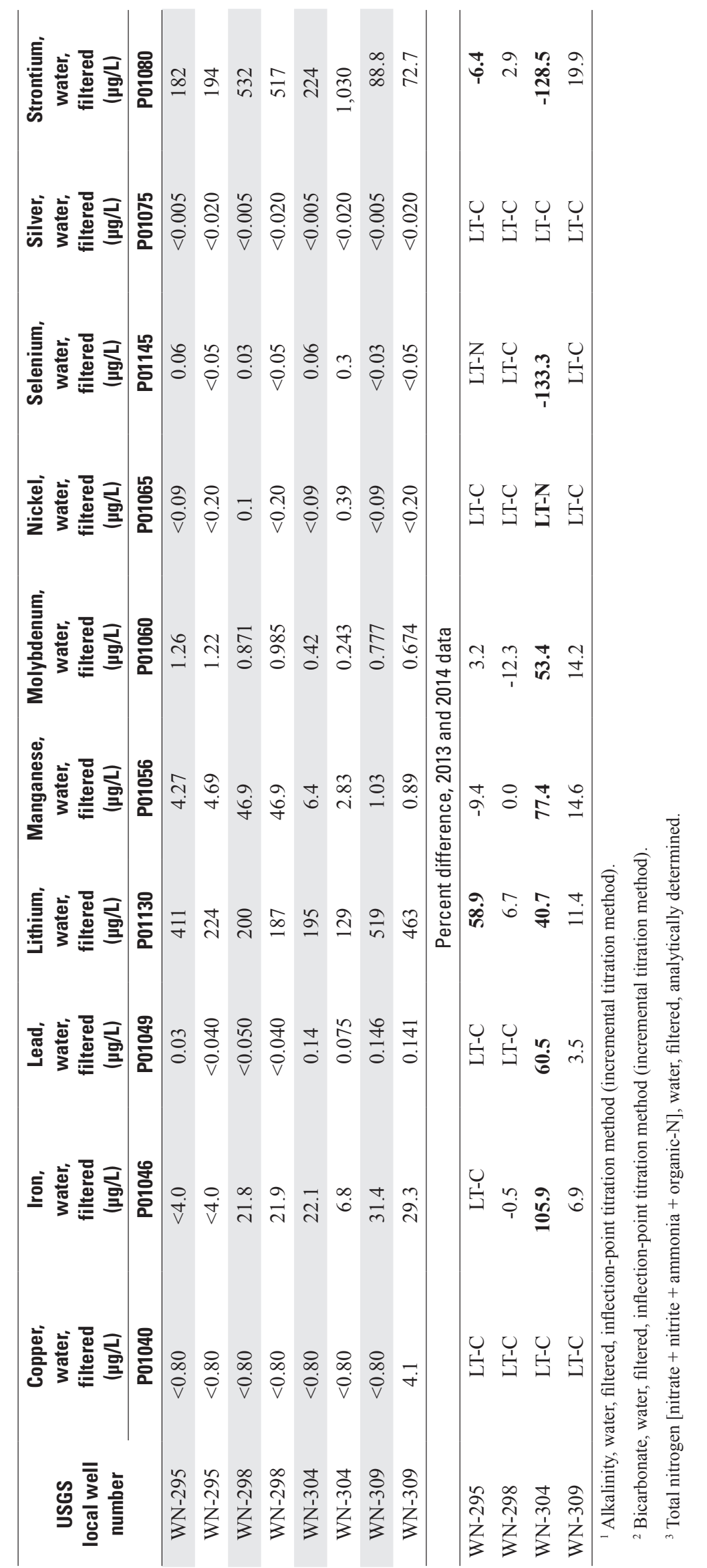

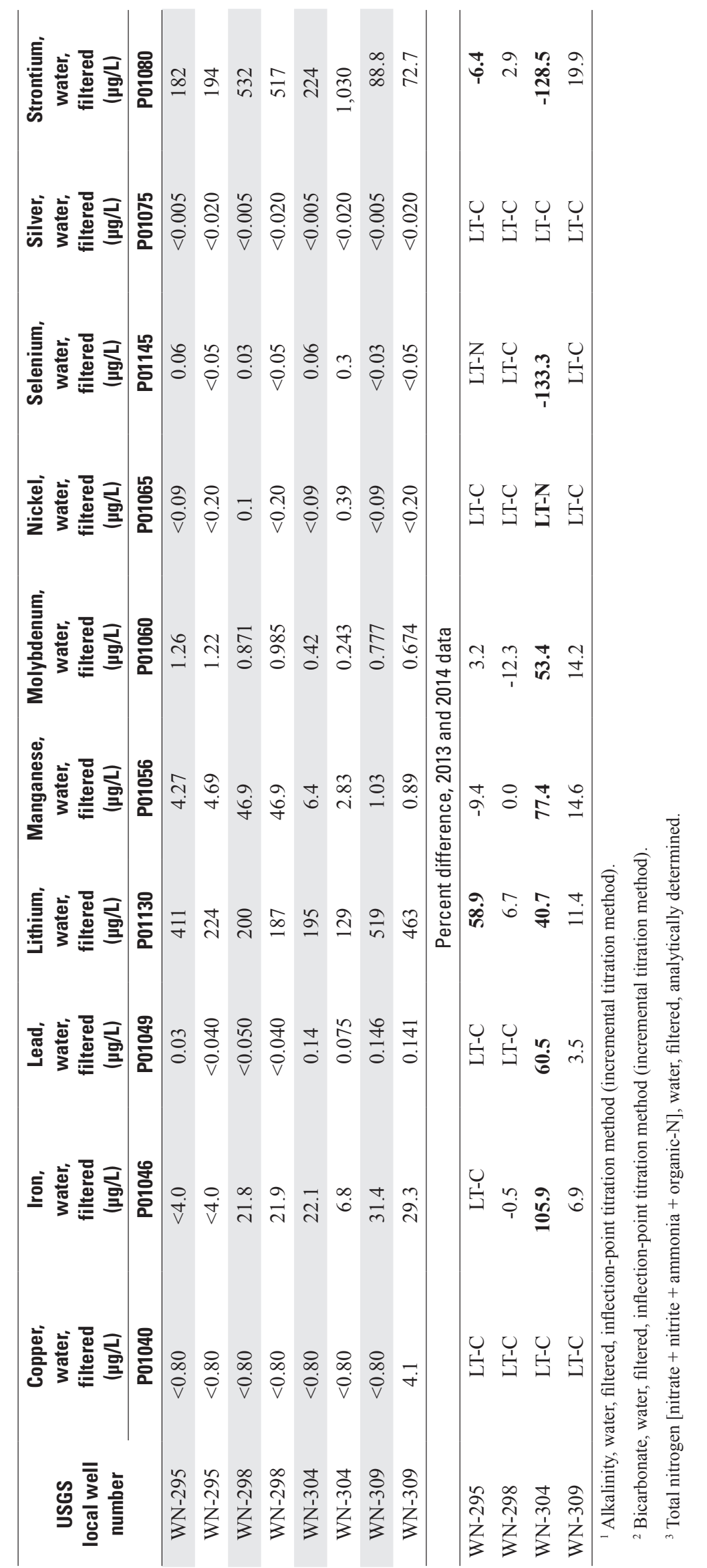
| | | 흔 늘 iv $v$ in 究 逑 空 |

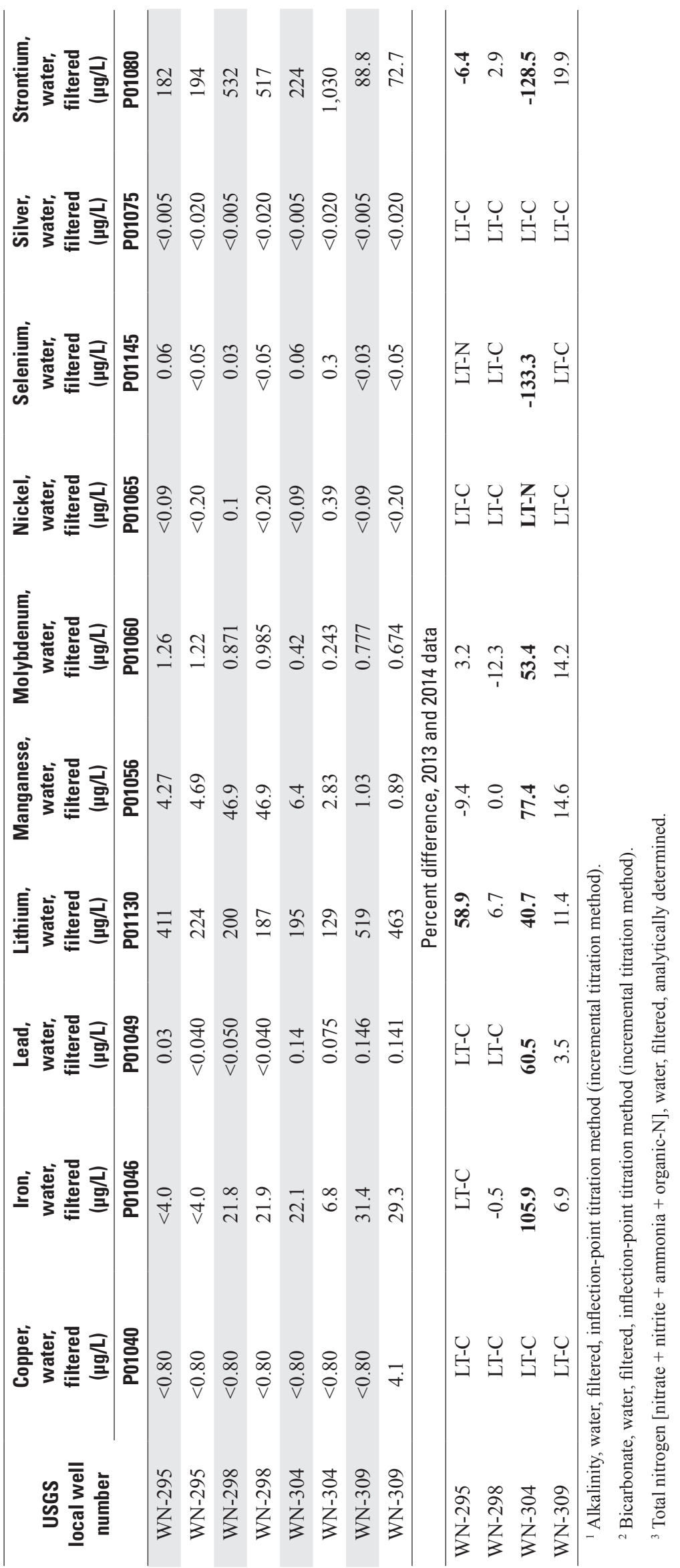
事 的焉

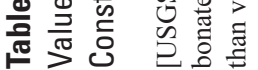




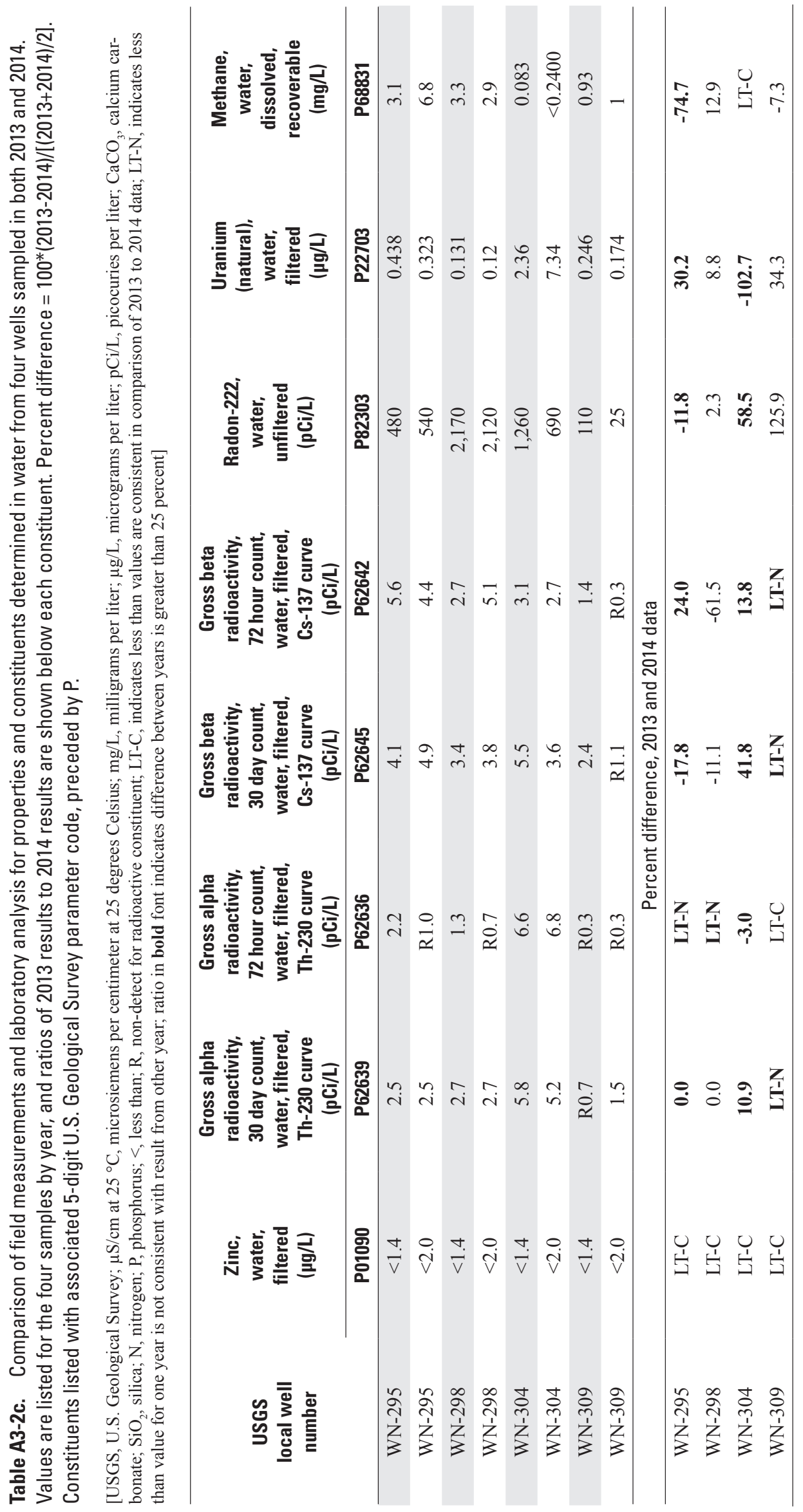



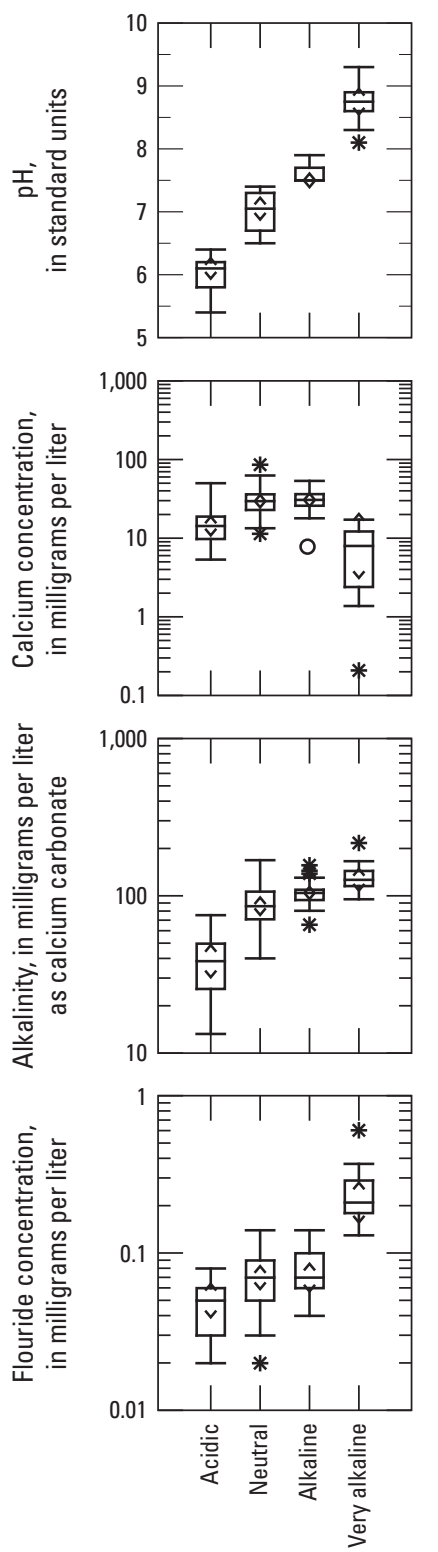

$\mathrm{pH}$ class
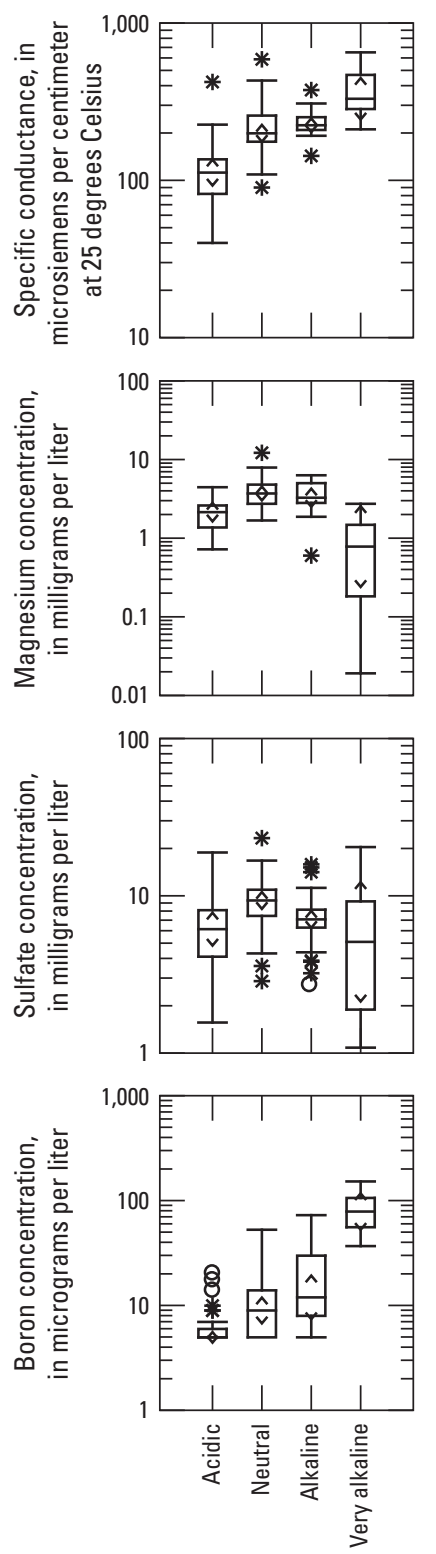

$\mathrm{pH}$ class
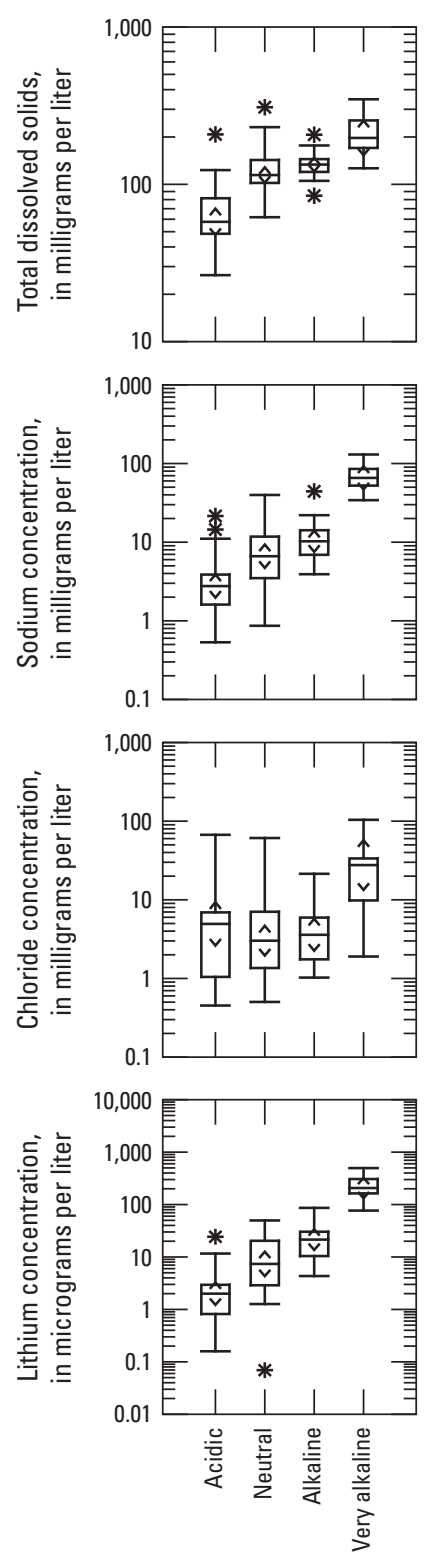

$\mathrm{pH}$ class
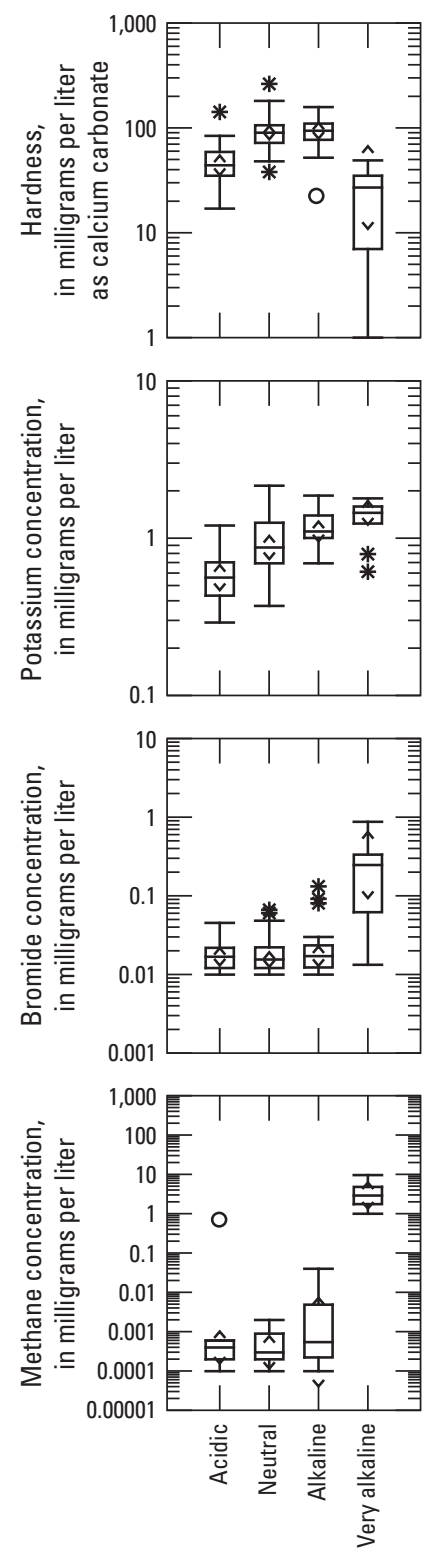

$\mathrm{pH}$ class

\section{EXPLANATION}

○ Outlier data value more than 3 times the interquartile range outside the quartile

* Outlier data value less than or equal to 3 and more than $\mathbf{1 . 5}$ times the interquartile range outside the quartile

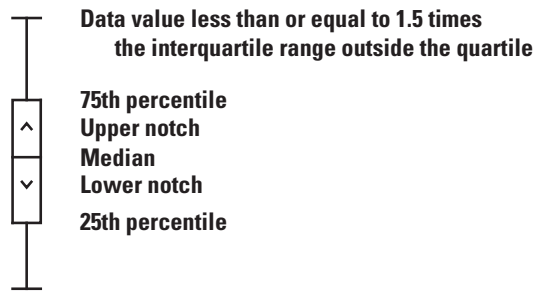

Figure 4-1. Boxplots showing differences in compositions of 121 groundwater samples from 117 wells in Wayne County, Pennsylvania, 2013-14, classified by pH class interval as "acidic" $(5.4<\mathrm{pH}<6.4, \mathrm{n}=29)$, “neutral” $(6.5<\mathrm{pH}<7.4, \mathrm{n}=32)$, "alkaline" (7.5<pH $<7.9, \mathrm{n}=25)$, and "very alkaline" $(8.0<\mathrm{pH}<9.4, \mathrm{n}=9)$. 

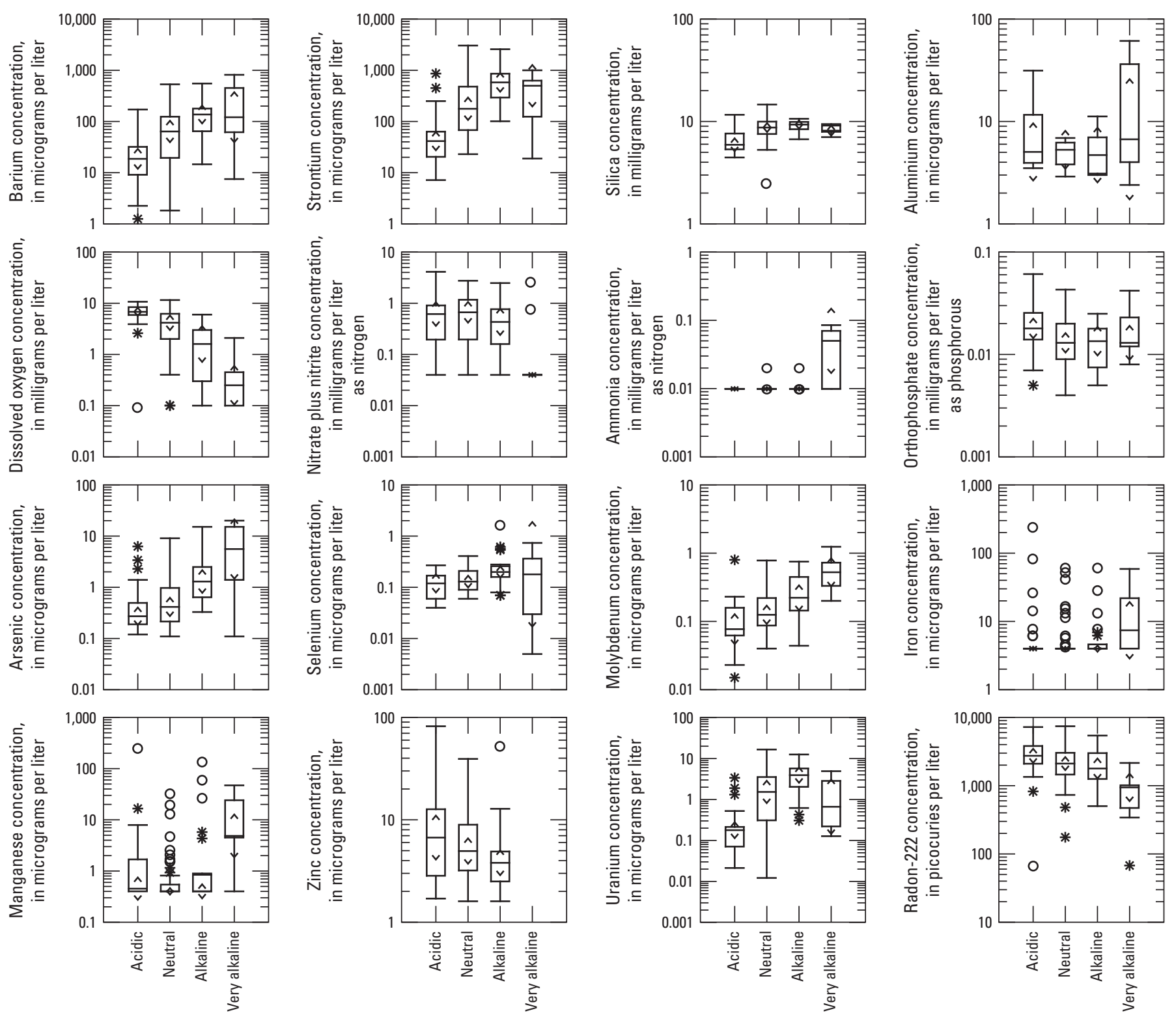

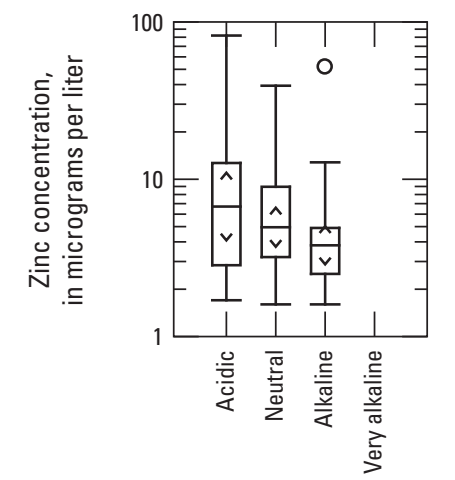

$\mathrm{pH}$ class

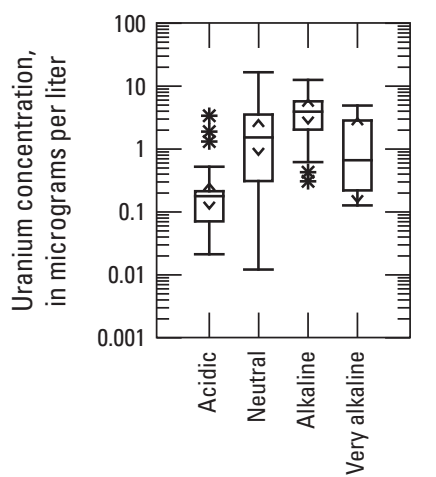

$\mathrm{pH}$ class

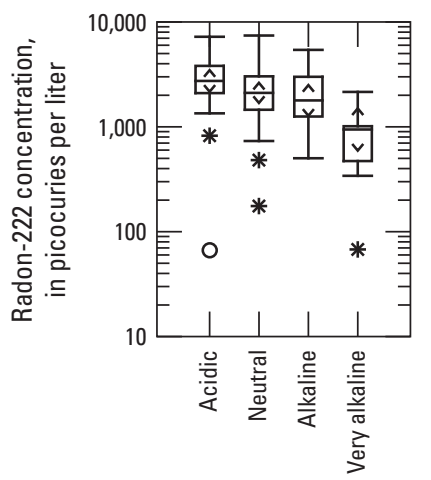

pH class

\section{EXPLANATION}

○ Outlier data value more than 3 times the interquartile range outside the quartile

* Outlier data value less than or equal to 3 and more than 1.5 times the interquartile range outside the quartile

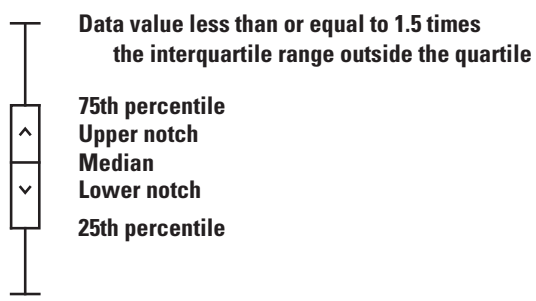

Figure 4-1. Boxplots showing differences in compositions of 121 groundwater samples from 117 wells in Wayne County, Pennsylvania, 2013-14, classified by $\mathrm{pH}$ class interval as "acidic" (5.4<pH $<6.4, \mathrm{n}=29)$, "neutral" $(6.5<\mathrm{pH}<7.4, \mathrm{n}=32)$, "alkaline" $(7.5<\mathrm{pH}<7.9, \mathrm{n}=25)$, and "very alkaline" $(8.0<\mathrm{pH}<9.4, \mathrm{n}=9)$. - Continued 

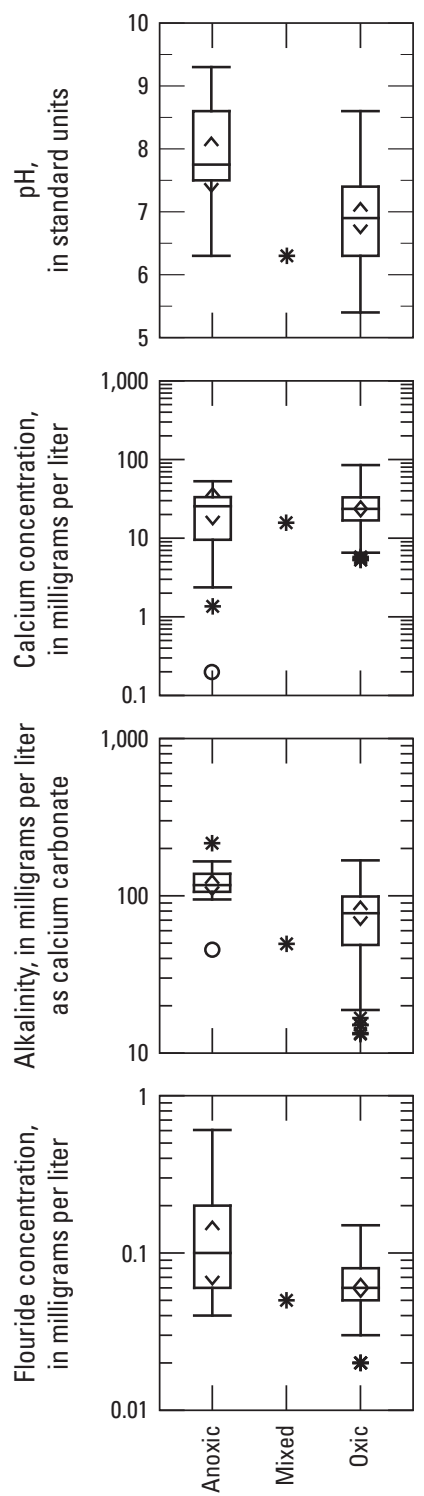

Redox class
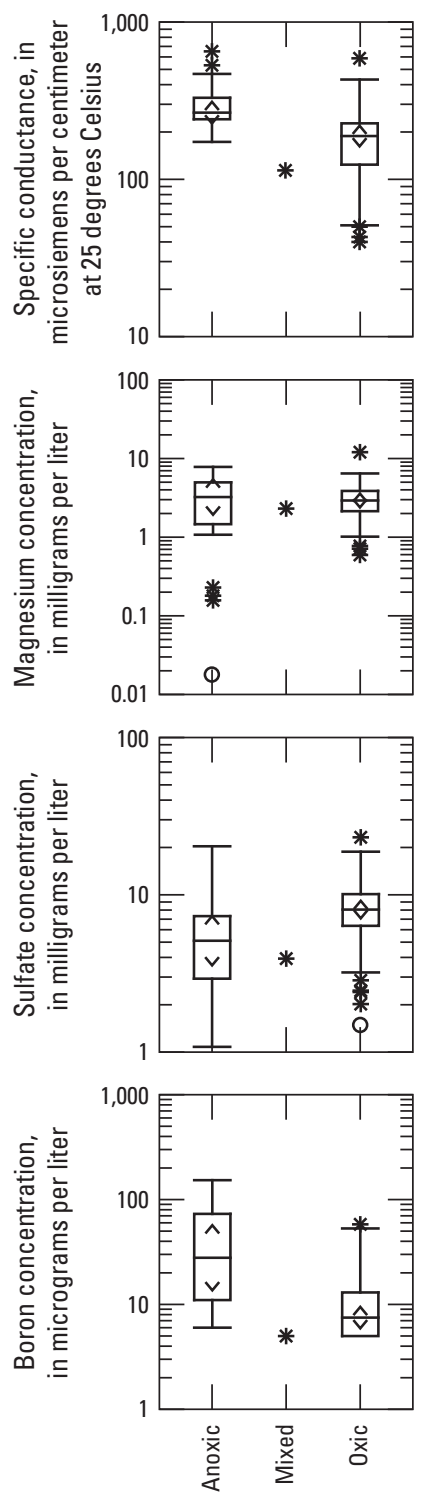

Redox class
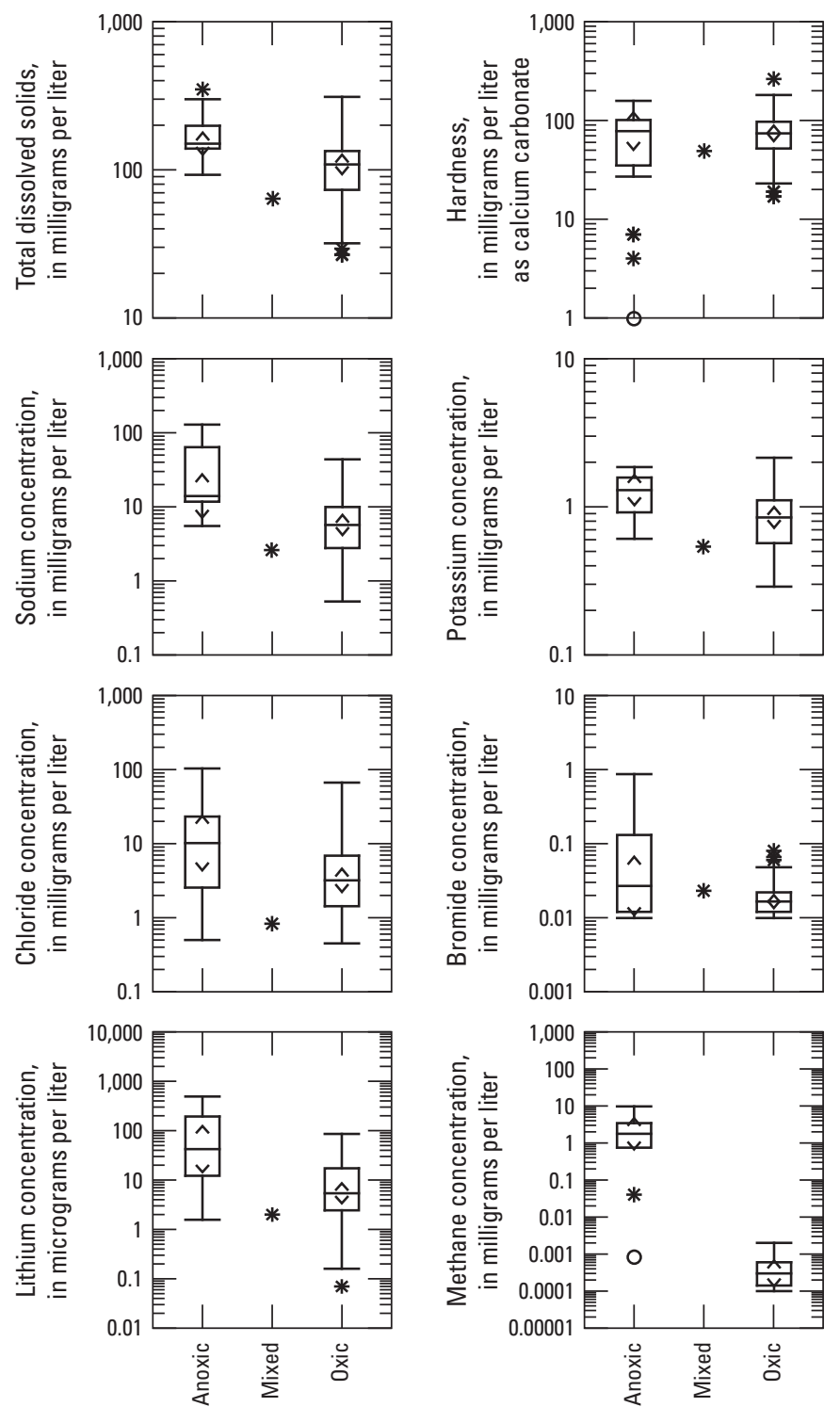

Redox class

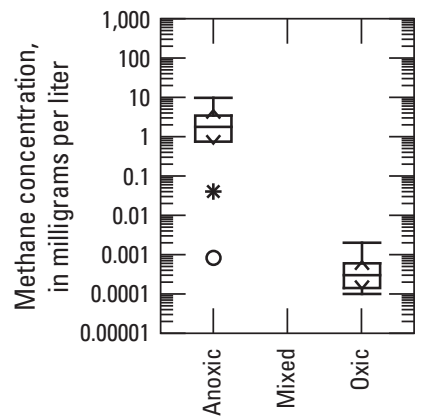

Redox class

\section{EXPLANATION}

O Outlier data value more than 3 times the interquartile range outside the quartile

* Outlier data value less than or equal to 3 and more than 1.5 times the interquartile range outside the quartile

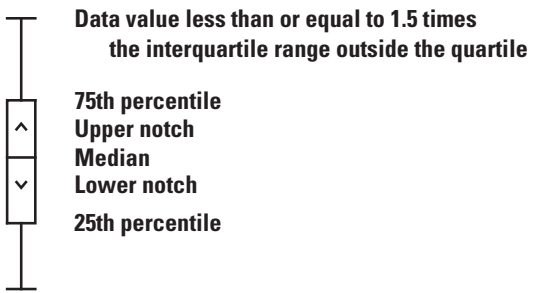

Figure 4-2. Boxplots showing differences in compositions of 121 groundwater samples from 117 wells in Wayne County, Pennsylvania, 2013-14, classified as "anoxic" ( $n=25)$, "mixed" (n=1), and "oxic" ( $=95)$ on the basis of dissolved oxygen concentration and other water-quality criteria of McMahon and Chapelle (2008). 

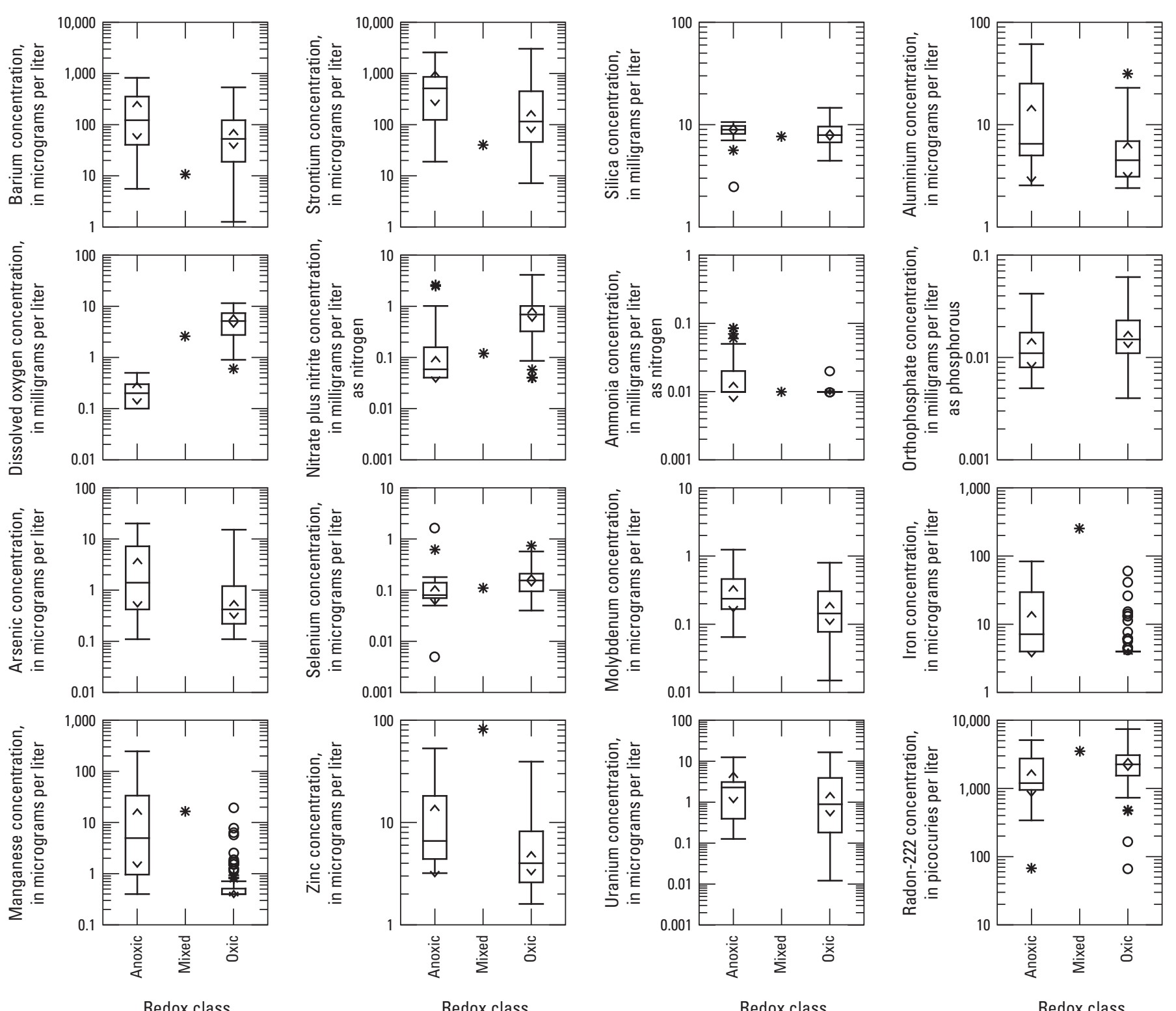

Redox class

Redox class

Redox class

Redox class

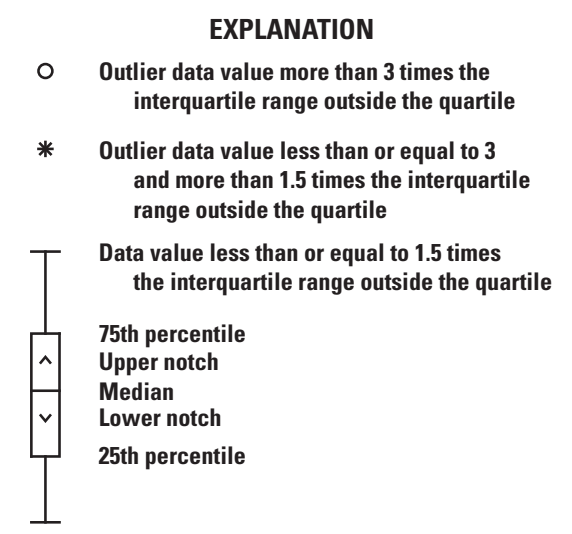

Figure 4-2. Boxplots showing differences in compositions of 121 groundwater samples from 117 wells in Wayne County, Pennsylvania, 2013-14, classified as "anoxic" ( $n=25)$, "mixed" ( $n=1)$, and "oxic" ( $n=95)$ on the basis of dissolved oxygen concentration and other water-quality criteria of McMahon and Chapelle (2008). - Continued 

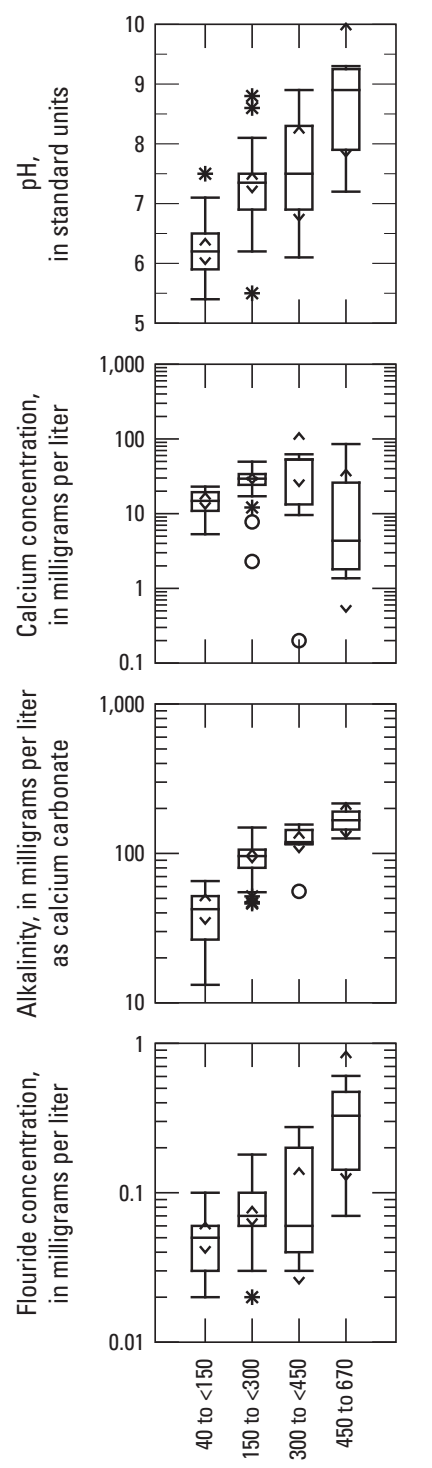

Specific conductance range, in microsiemens per centimeter at 25 degrees Celsius
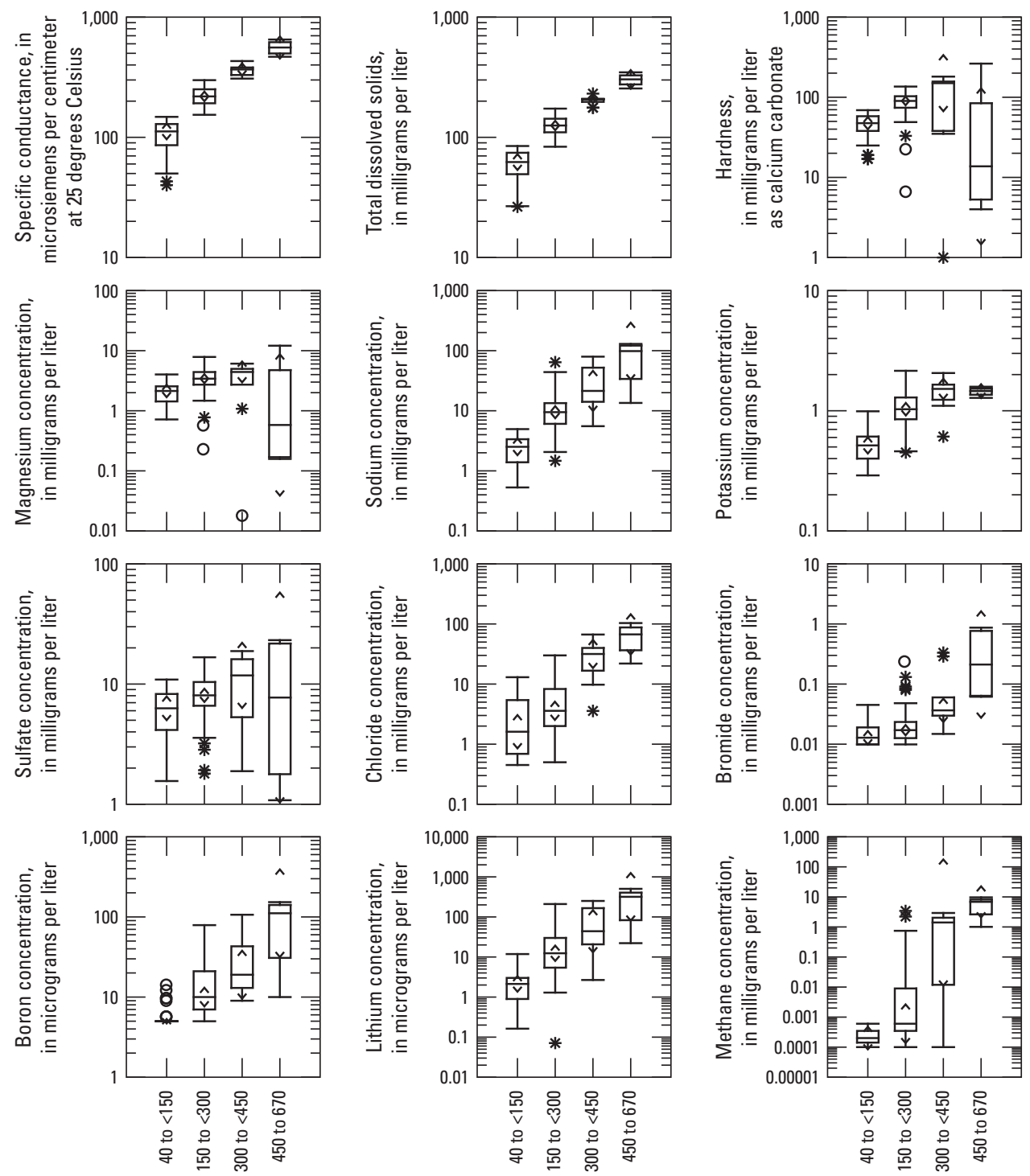

Specific conductance range, in microsiemens per centimeter at 25 degrees Celsius
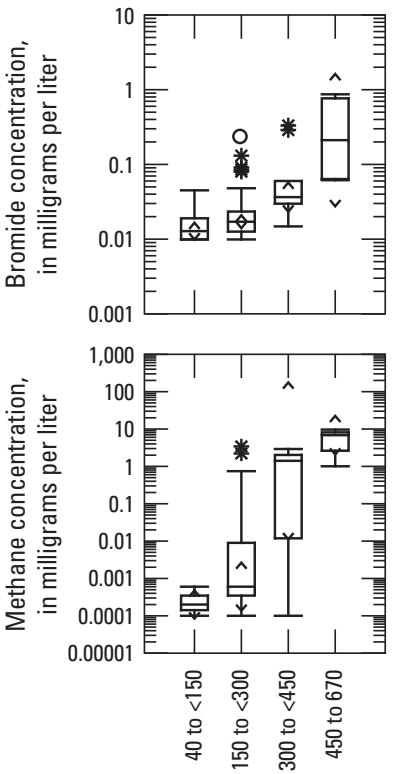

Specific conductance range, in microsiemens per centimeter at 25 degrees Celsius
EXPLANATION

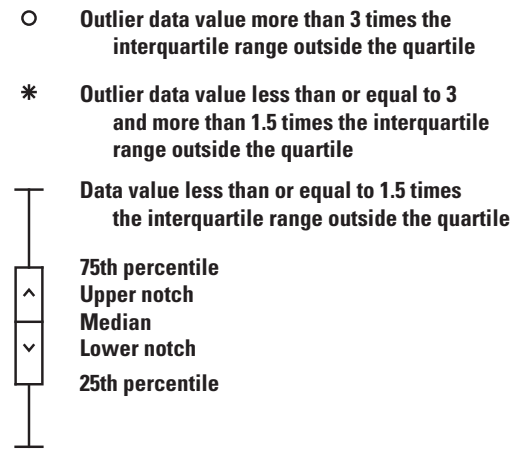

Figure 4-3. Boxplots showing differences in compositions of 121 groundwater samples from 117 wells in Wayne County, Pennsylvania, 2013-14, grouped by ranges in specific conductance (SC) given in units of microsiemens per centimeter of 40 to $<150(n=34), 150$ to $<300(n=70), 300$ to $<450(n=9)$, and 450 to $670(n=4)$. 

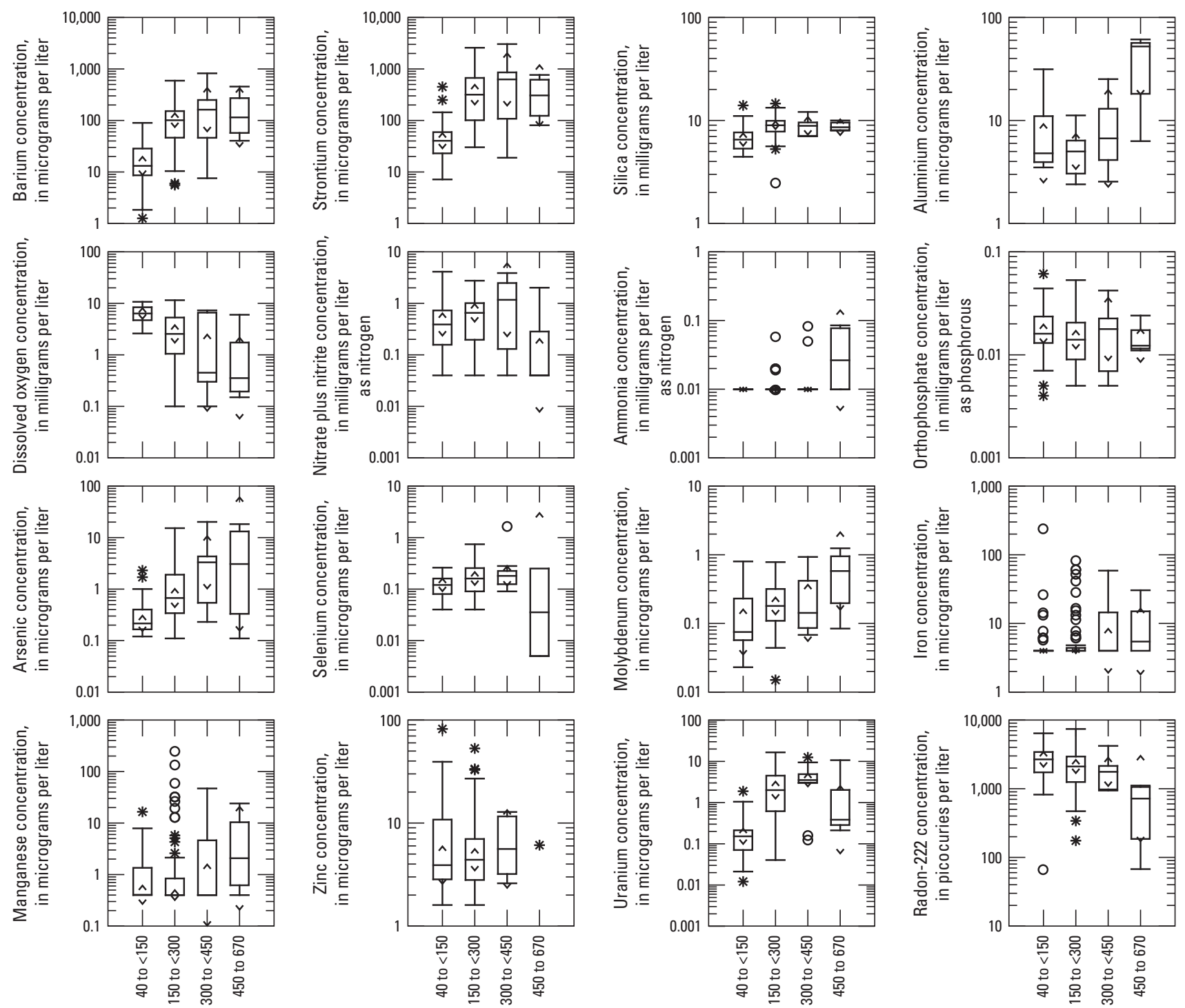

Specific conductance range, in microsiemens per centimeter at 25 degrees Celsius

$$
\begin{gathered}
\text { Specific conductance range, } \\
\text { in microsiemens per centimeter } \\
\text { at } 25 \text { degrees Celsius }
\end{gathered}
$$

Specific conductance range,
in microsiemens per centimeter at 25 degrees Celsius
Specific conductance range, in microsiemens per centimeter at 25 degrees Celsius

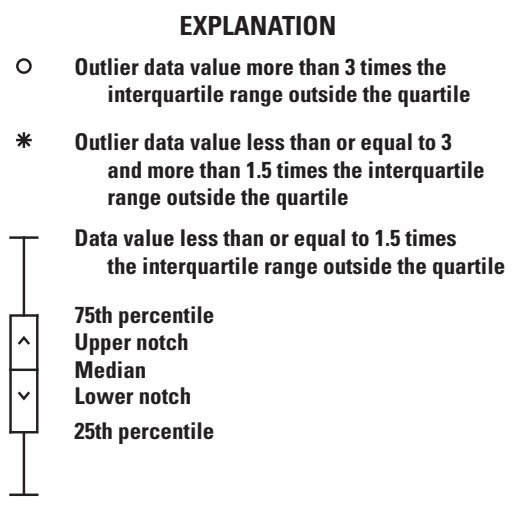

Figure 4-3. Boxplots showing differences in compositions of 121 groundwater samples from 117 wells in Wayne County, Pennsylvania, 2013-14, grouped by ranges in specific conductance (SC) given in units of microsiemens per centimeter of 40 to $<150(n=34), 150$ to $<300(n=70), 300$ to $<450(n=9)$, and 450 to $670(n=4)$. - Continued 
A. Grouped by pH class

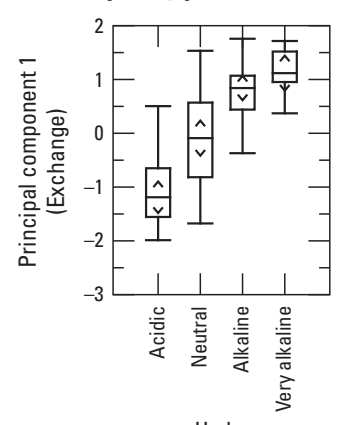

$\mathrm{pH}$ class

B. Grouped by redox class

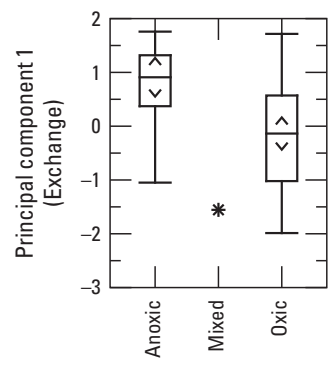

Redox class

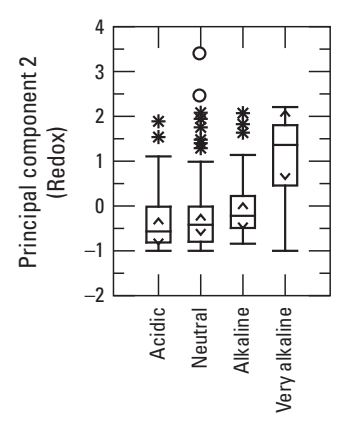

$\mathrm{pH}$ class

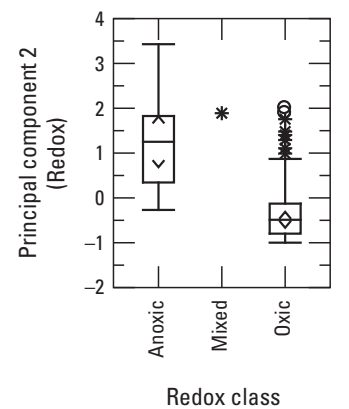

Redox class

C. Grouped by specific conductance range

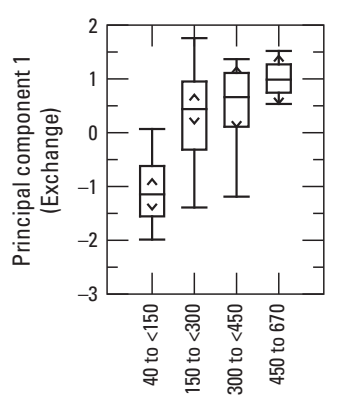

Specific conductance range, in microsiemens per centimeter at 25 degrees Celsius

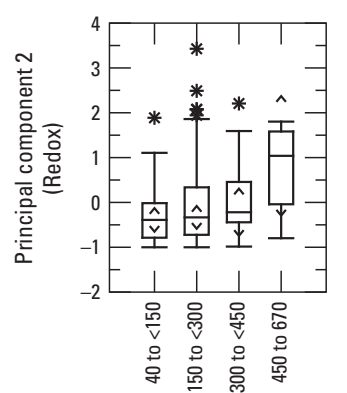

Specific conductance range, in microsiemens per centimeter at 25 degrees Celsius

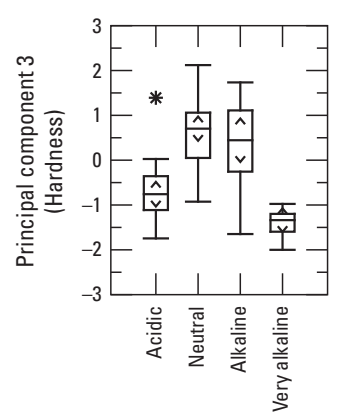

$\mathrm{pH}$ class

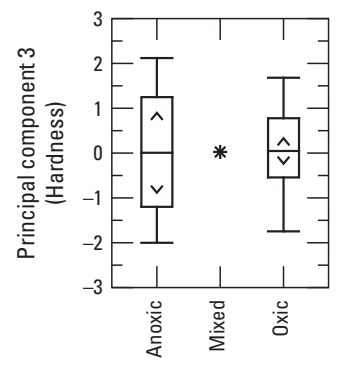

Redox class

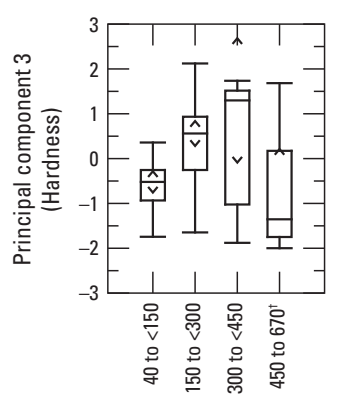

Specific conductance range, in microsiemens per centimeter at 25 degrees Celsius
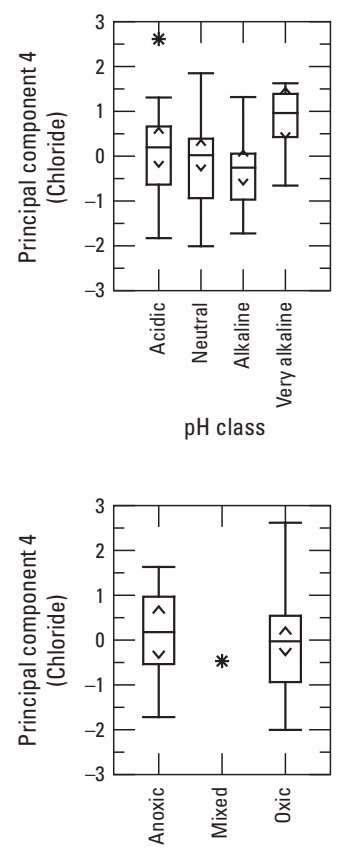

Redox class

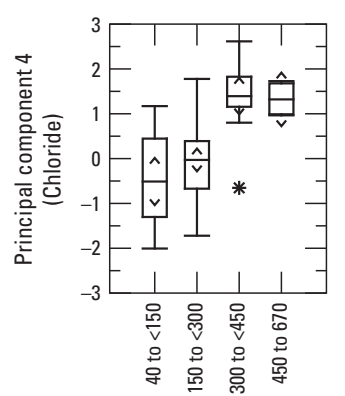

Specific conductance range, in microsiemens per centimeter at 25 degrees Celsius

EXPLANATION

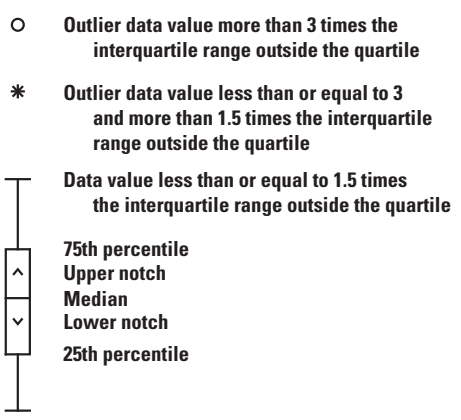

$\dagger \quad$ Lower notch is out of range

Figure 4-4. Boxplots showing distribution of principal component scores for 121 groundwater samples from 117 wells in Wayne County, Pennsylvania, 2013-14, classified by pH class interval as "acidic" $(5.4<\mathrm{pH}<6.4, \mathrm{n}=29)$, "neutral" $(6.5<\mathrm{pH}<7.4, \mathrm{n}=32)$, "alkaline" (7.5< $\mathrm{pH}<7.9, \mathrm{n}=25)$, and "very alkaline" $(8.0<\mathrm{pH}<9.4, \mathrm{n}=9)$; redox class interval "anoxic" $(\mathrm{n}=25)$, "mixed" ( $\mathrm{n}=1)$, and "oxic" ( $n=95)$; and specific conductance (SC) given in units of microsiemens per centimeter of 40 to $<150$ ( $n=34$ ), 150 to $<300$ $(n=70), 300$ to $<450(n=9)$, and 450 to $670(n=4)$. Redox classification is based on dissolved oxygen concentration and other waterquality criteria of McMahon and Chapelle (2008). Principal component model consist of four principal components or factors shown in table 5. (PC, principal component) 

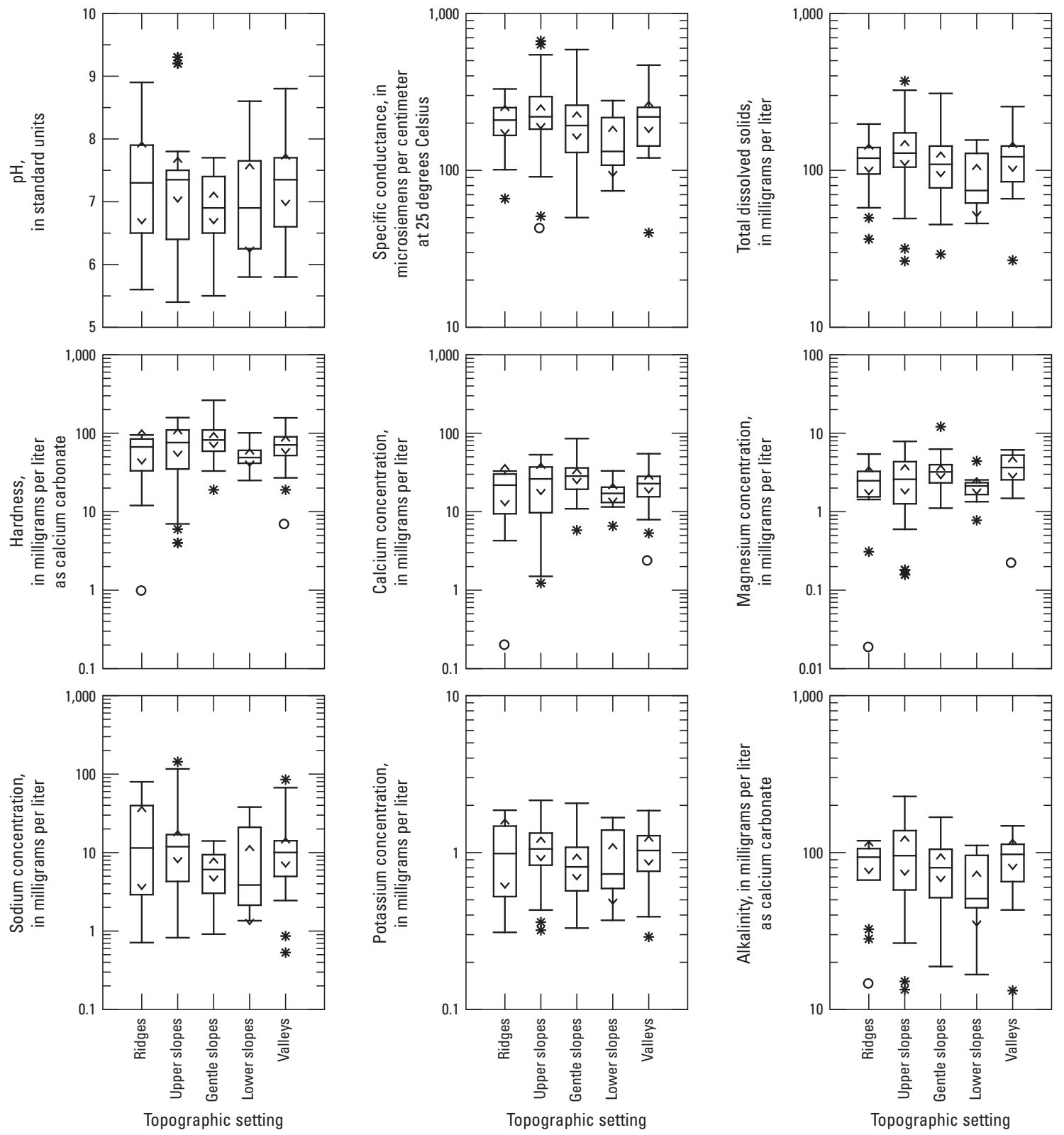

EXPLANATION

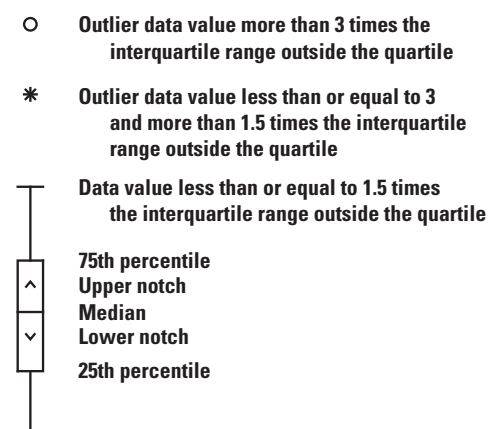

Figure 4-5. Boxplots showing differences in compositions of 121 groundwater samples from 117 wells in Wayne County, Pennsylvania, 2013-14, for five major topographic settings classified as ridges $(n=13)$, upper slopes $(n=0)$, gentle slopes $(n=45)$, lower slopes $(n=11)$, and valleys $(n=22)$ on the basis of the 30 -meter digital elevation model and criteria reported by Llewellyn (2014). Location of samples and topographic classification shown on figure 4-6. 

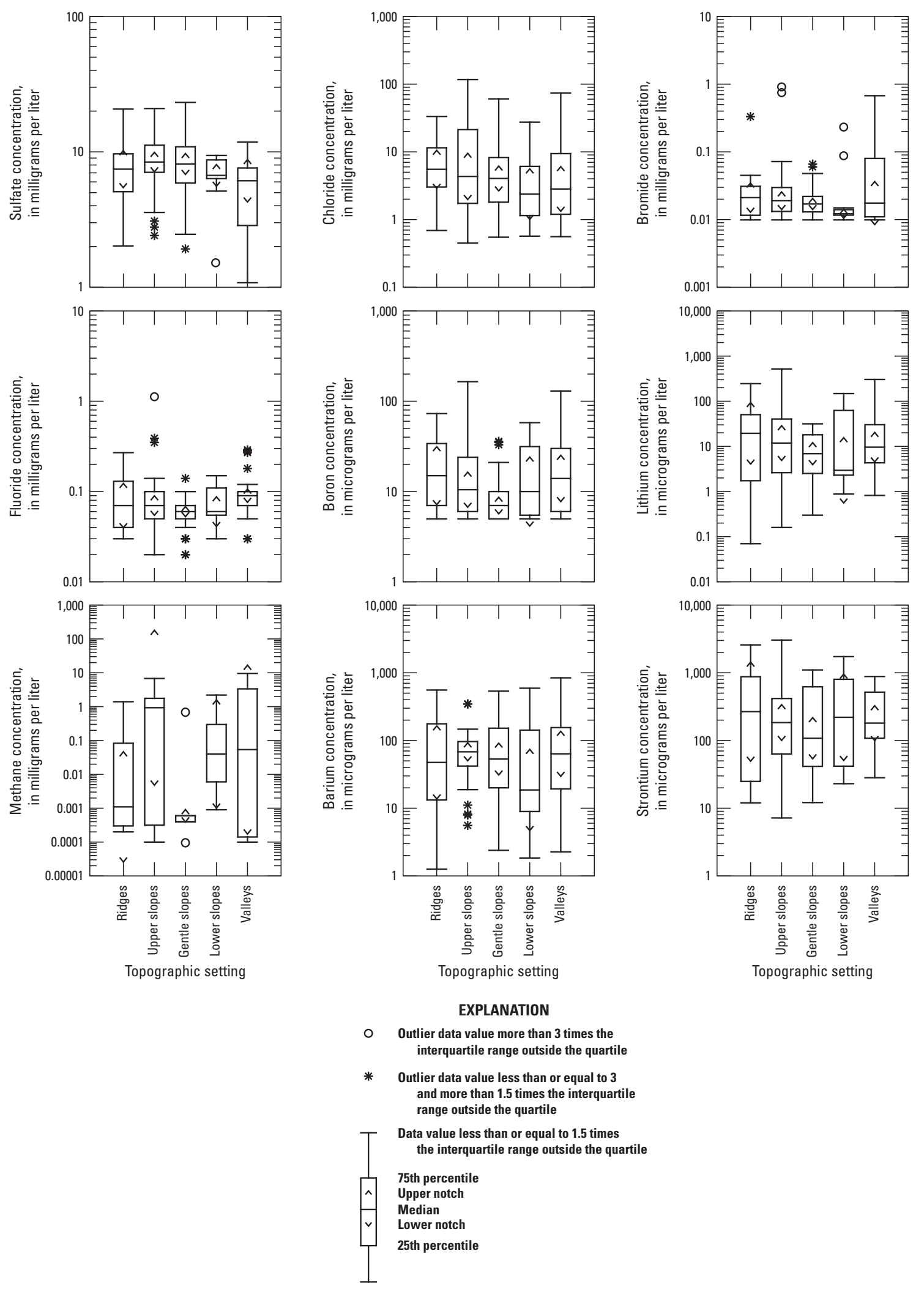

Figure 4-5. Boxplots showing differences in compositions of 121 groundwater samples from 117 wells in Wayne County, Pennsylvania, 2013-14, for five major topographic settings classified as ridges $(n=13)$, upper slopes $(n=0)$, gentle slopes $(n=45)$, lower slopes $(n=11)$, and valleys $(n=22)$ on the basis of the 30-meter digital elevation model and criteria reported by Llewellyn (2014). Location of samples and topographic classification shown on figure 4-6. - Continued 

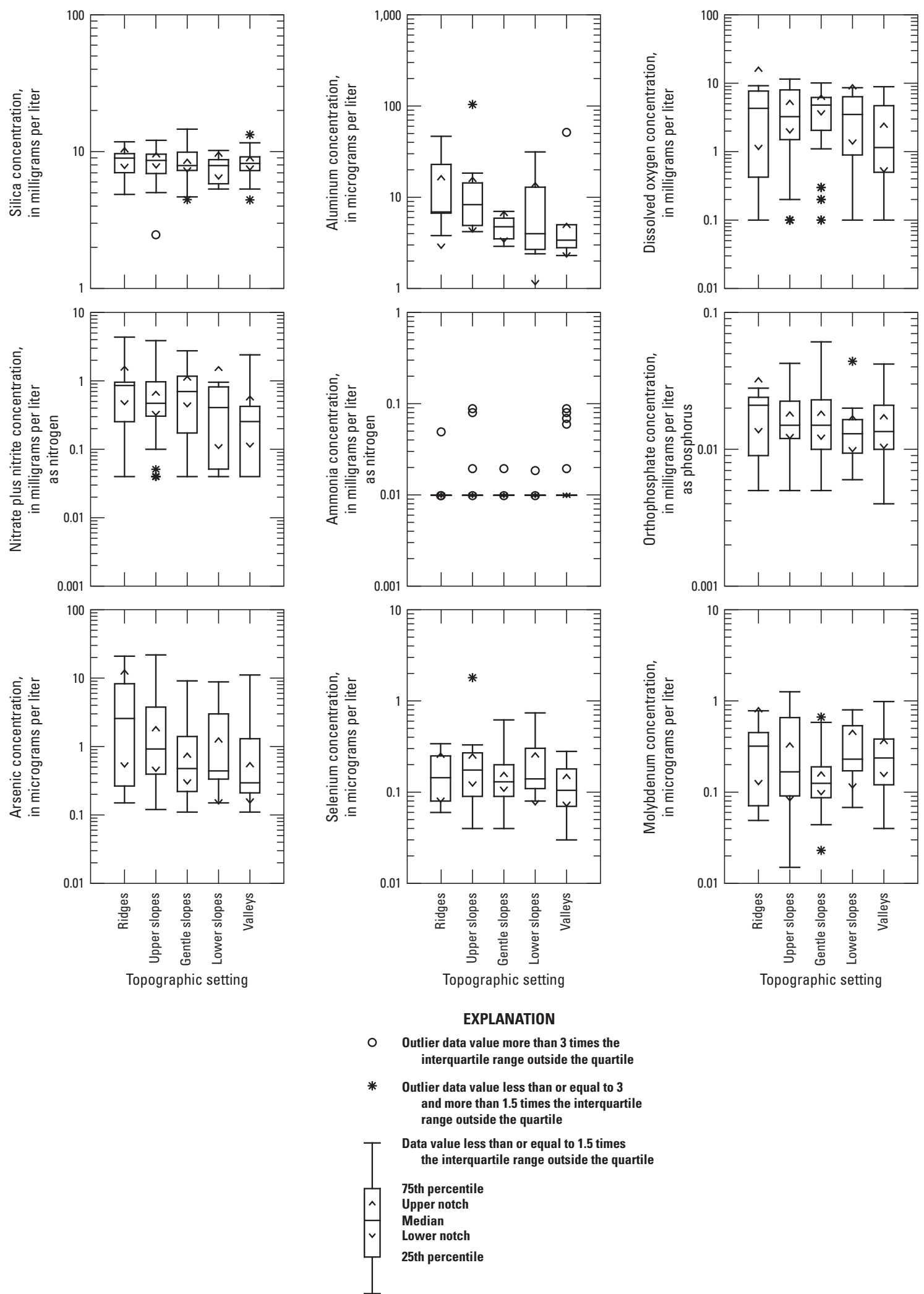

Figure 4-5. Boxplots showing differences in compositions of 121 groundwater samples from 117 wells in Wayne County, Pennsylvania, 2013-14, for five major topographic settings classified as ridges $(n=13)$, upper slopes $(n=0)$, gentle slopes $(n=45)$, lower slopes $(n=11)$, and valleys $(n=22)$ on the basis of the 30 -meter digital elevation model and criteria reported by Llewellyn (2014). Location of samples and topographic classification shown on figure 4-6.-Continued 

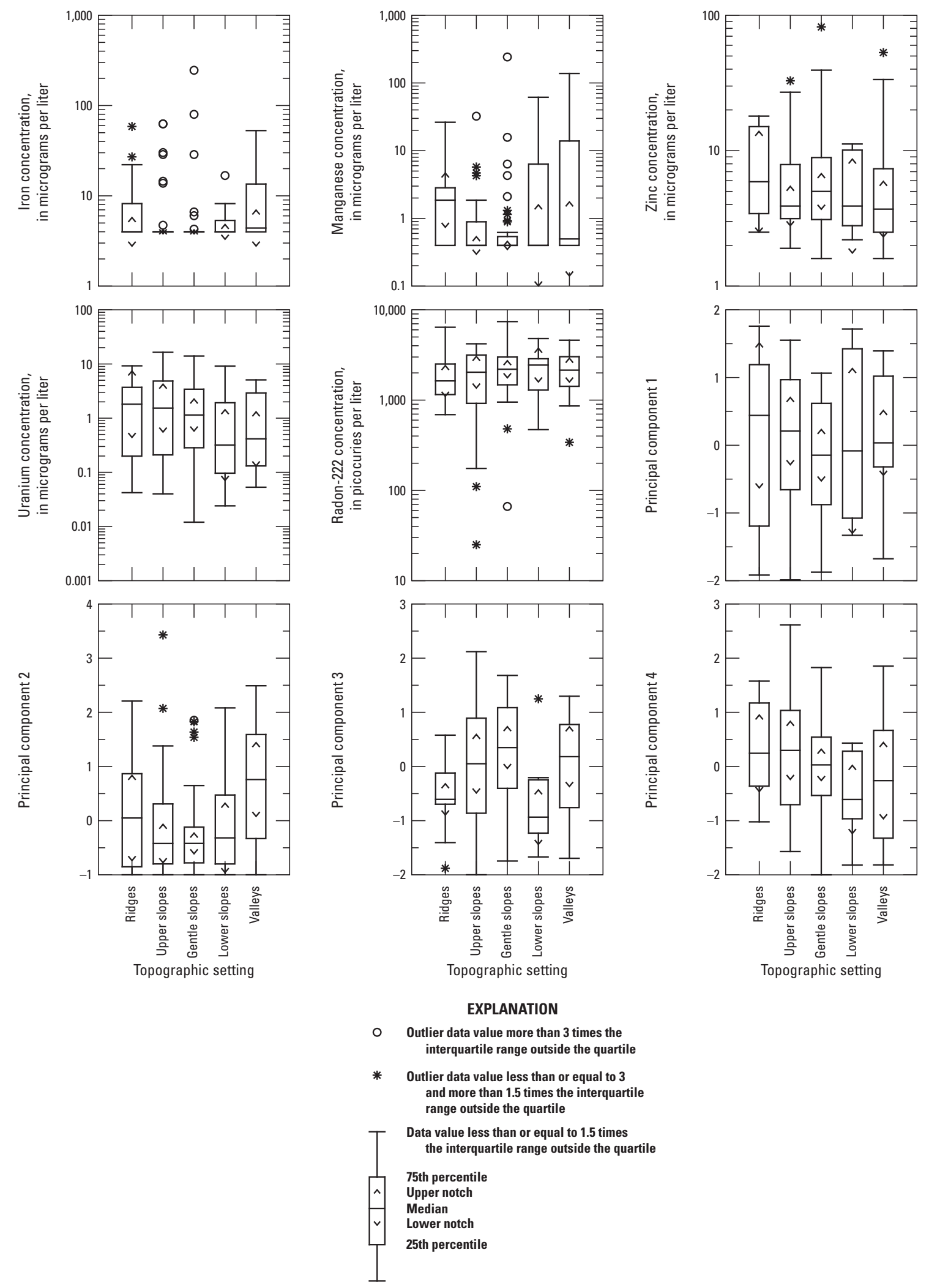

Figure 4-5. Boxplots showing differences in compositions of 121 groundwater samples from 117 wells in Wayne County, Pennsylvania, 2013-14, for five major topographic settings classified as ridges $(n=13)$, upper slopes $(n=0)$, gentle slopes $(n=45)$, lower slopes $(n=11)$, and valleys $(n=22)$ on the basis of the 30-meter digital elevation model and criteria reported by Llewellyn (2014). Location of samples and topographic classification shown on figure 4-6. - Continued 


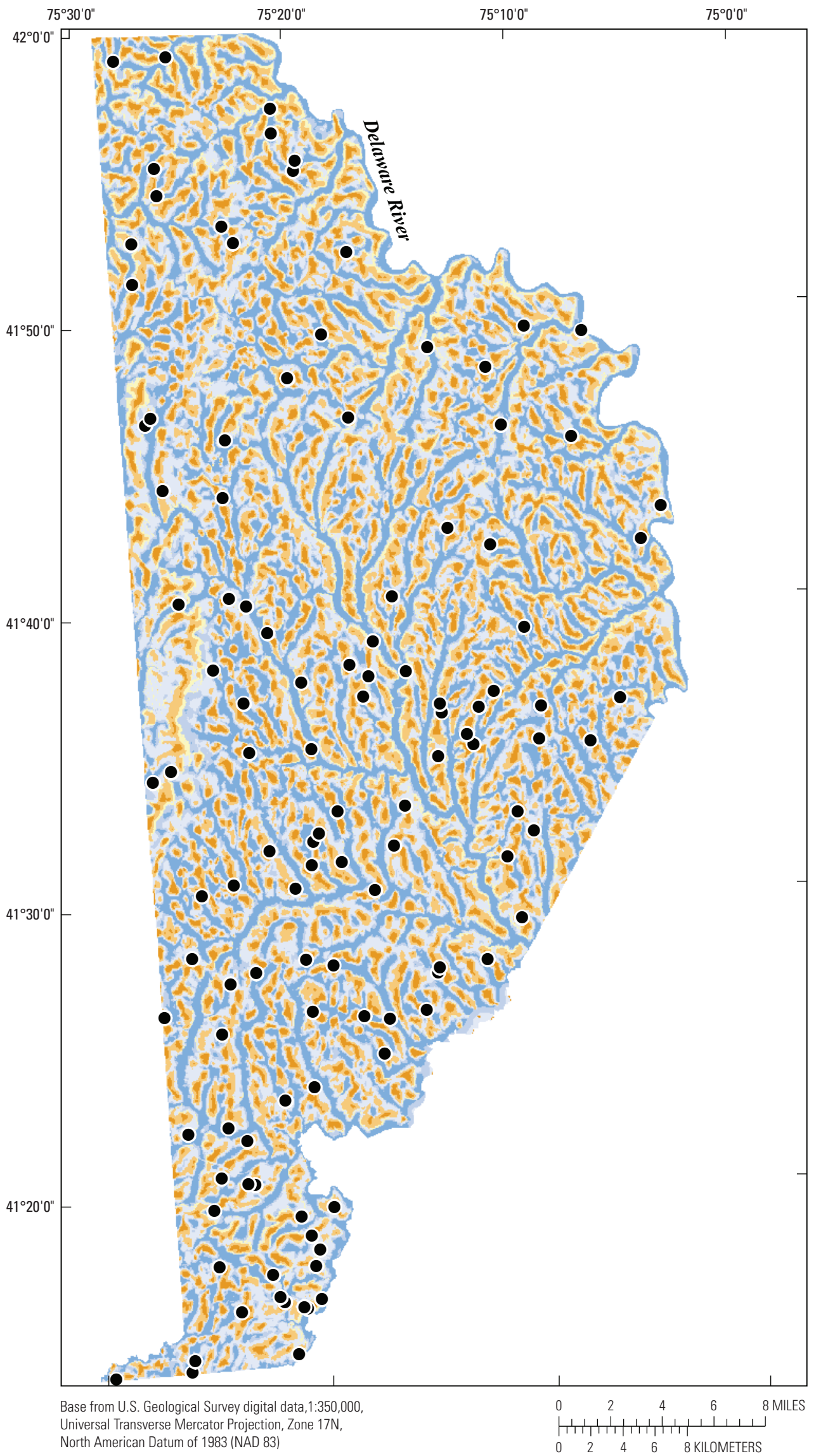

\section{EXPLANATION}

Topographic Position Index (TPI) categories

\begin{tabular}{|l|l}
\hline & Valleys (TPI less than or equal to \\
-0.6 meters) \\
Lower slopes (TPI greater than \\
-0.6 meters and less than or equal \\
to -0.3 meters) \\
Gentle slopes (TPI greater than \\
-0.3 meters and less than or equal \\
to 0.4 meters, slope less than or \\
equal to 10 degrees) \\
Steep slopes (TPI greater than \\
-0.3 meters and less than or equal \\
to 0.4 meters, slope greater than \\
10 degrees) \\
Upper slopes (TPI greater than \\
0.4 meters and less than or equal \\
to 1 meter) \\
Ridges (TPI greater than 1 meter)
\end{tabular}

- Sampled wells (117)

Figure 4-6. Location and topographic setting of 121 groundwater samples from 117 wells in Wayne County, Pennsylvania, 2013-14, for five major topographic index classifications-ridges, upper slopes, gentle slopes, lower slopes, and valleys - on the basis of the 30-meter digital elevation model and criteria reported by Llewellyn (2014). (ridges, $n=13$; upper slopes, $n=30$; gentle slopes, $n=45$; lower slopes, $\mathrm{n}=11$; valleys, $\mathrm{n}=22$ ) 


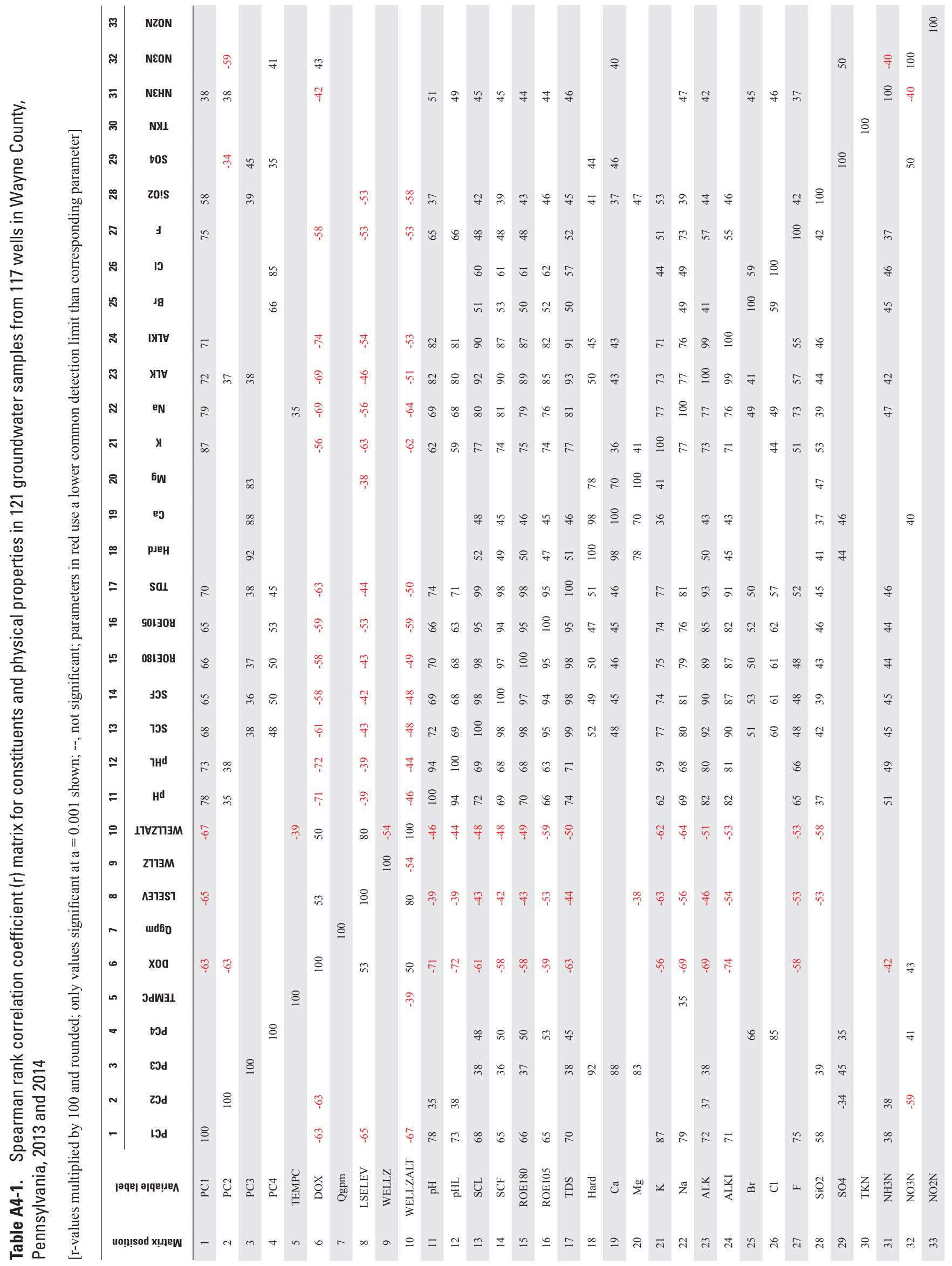




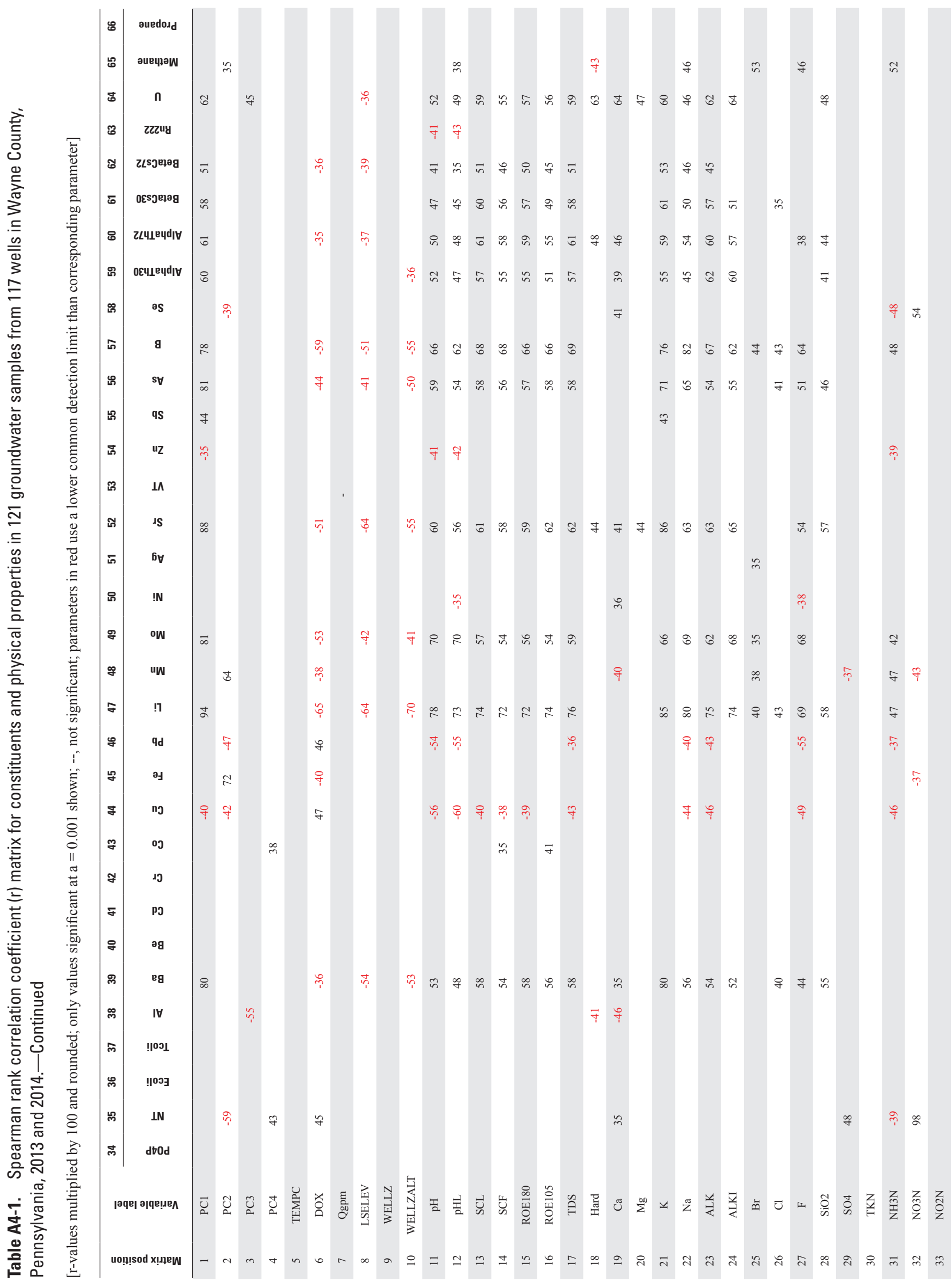




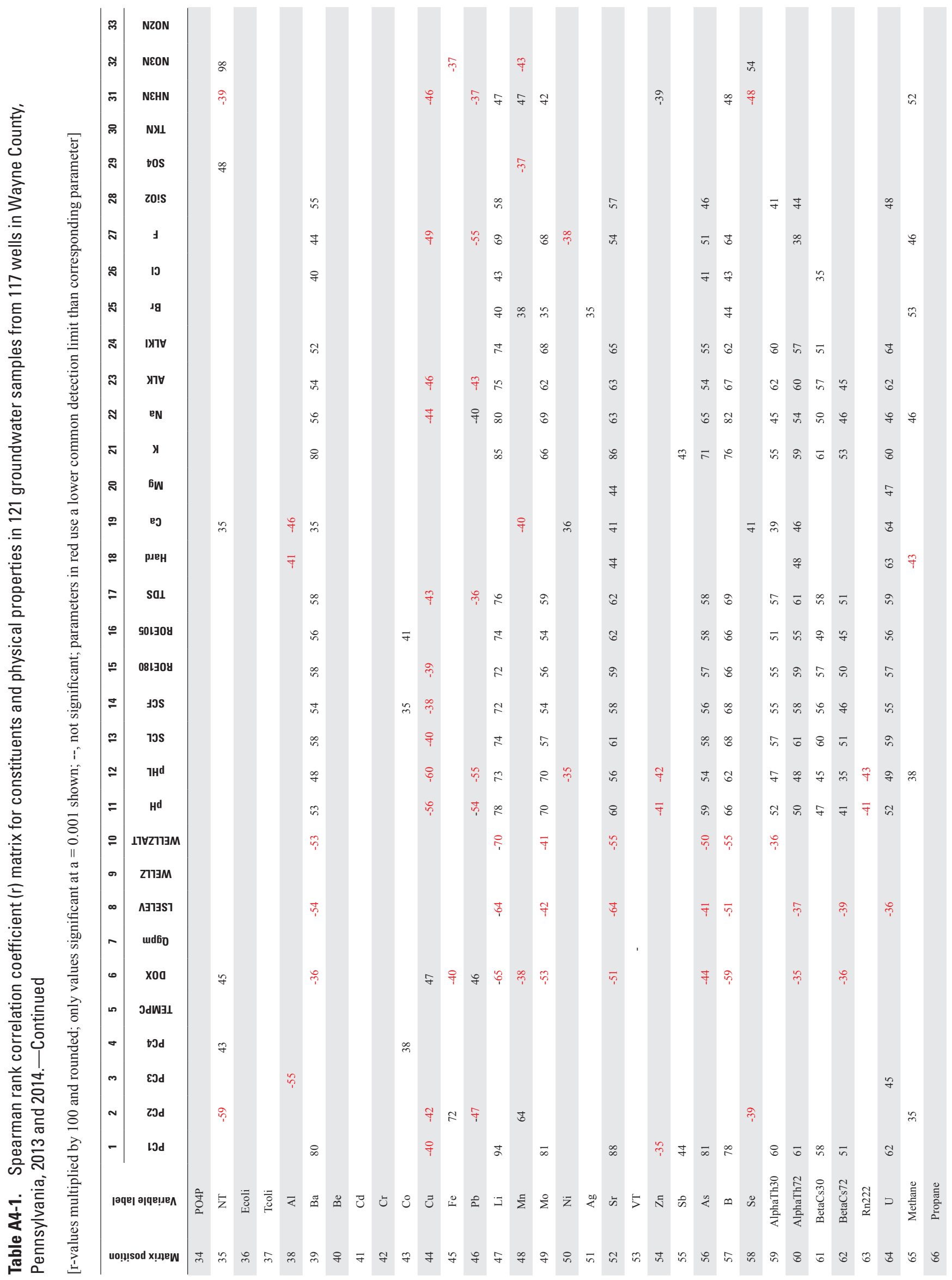




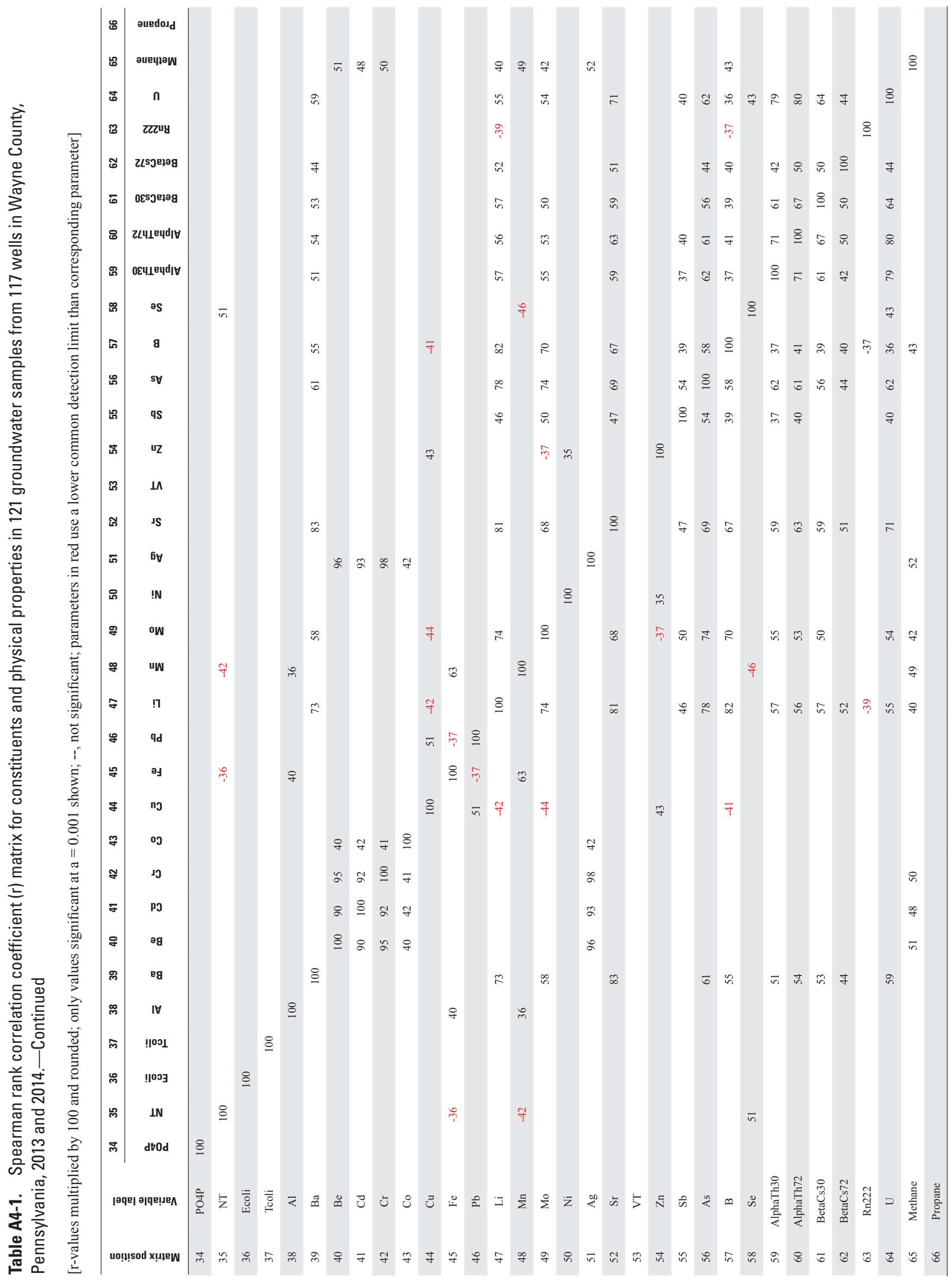




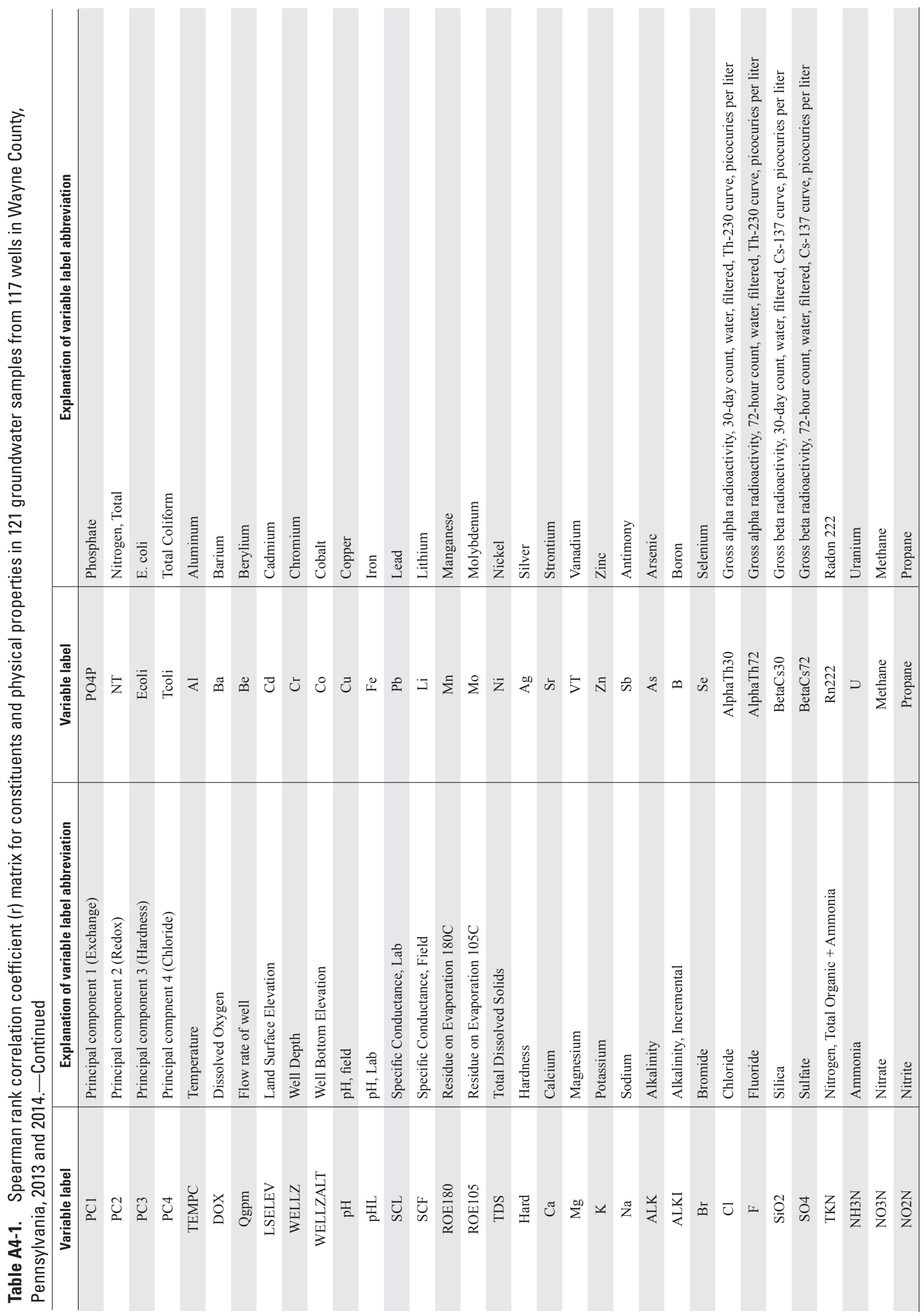


Prepared by USGS West Trenton Publishing Service Center.

For additional information, contact:

Director, Pennsylvania Water Science Center

U.S. Geological Survey

215 Limekiln Road

New Cumberland, PA 17070-2424

or visit our Web site at:

http://pa.water.usgs.gov 


\section{$\mathbb{R}$ \\ 营}

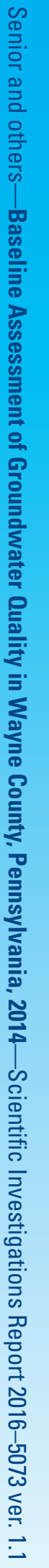

